\title{
Recent applications of the Suzuki-Miyaura cross-coupling reaction in organic synthesis
}

\author{
Sambasivarao Kotha, ${ }^{*}$ Kakali Lahiri and Dhurke Kashinath \\ Department of Chemistry, Indian Institute of Technology-Bombay, Powai, Mumbai 400 076, India
}

\section{Contents}

1. Introduction 29634

2. Scope of the review 9634

3. Preparation of boronic acids and their derivatives $\quad 9635$

4. Catalyst development 9637

4.1. SM Coupling reactions with aryl chlorides 9637

4.2. SM Cross-coupling reactions by palladacyclic complexes 9639

4.3. SM Cross-coupling reactions with other novel palladium catalysts 9640

4.4. Nickel-catalysed SM cross-coupling reactions 9641

4.5. Two-phase SM cross-coupling reactions with water-soluble palladium complexes 9643

4.6. SM Cross-coupling reactions under phosphine-free Pd catalysts 9644

5. SM Cross-coupling reactions under green conditions 9644

6. Synthesis of biphenyls and related systems 9648

6.1. Biaryls and hetero-biaryls $\quad 9648$

$\begin{array}{lr}\text { 6.2. Biphenylene systems } & 9651\end{array}$

6.3. Binaphthyl systems 9653

6.4. Multiple SM cross-couplings 9656

6.4.1. Symmetrical polyaryls using SM cross-couplings 9656

6.4.2. Porphyrins using SM cross-couplings 9657

6.4.3. Thiophene derivatives using SM cross-couplings 9658

6.5. Asymmetric SM cross-coupling reactions 9659

7. Dendrimer synthesis via the SM cross-coupling 9660

8. Synthesis of unusual amino acids and peptides 9661

9. SM Cross-coupling involving $\mathrm{sp}^{3}, \mathrm{sp}^{2}$ and sp hybridized compounds 9665

9.1. Coupling of $\mathrm{sp}^{2}$ hybridised $\mathrm{C}-\mathrm{B}$ compounds 9665

9.2. Coupling of $\mathrm{sp}^{3}$ hybridised $\mathrm{C}-\mathrm{B}$ compounds 9667

$\begin{array}{ll}\text { 9.3. Coupling of sp hybridised C-B compounds } & 9670\end{array}$

10. Synthesis of natural and unnatural products 9670

10.1. Reactions involving alkyl- and arylboronic acids 9671

10.2. Reactions involving 9-BBN derivatives 9675

10.3. Reactions involving pinacol borane, catechol borane and boroxines 9677

11. Solid supported synthesis 9680

12. Formation of carbon-heteroatom $(\mathrm{C}-\mathrm{N}, \mathrm{C}-\mathrm{O}$ and $\mathrm{C}-\mathrm{S})$ bonds 9681

13. Synthesis of diaryl ketones via carbonylative SM cross-coupling 9684

14. Rhodium- and nickel-catalysed reactions of arylboronic acids 9686

$\begin{array}{ll}\text { 15. Conclusions and future prospects } & 9688\end{array}$

Keywords: arylation; biaryls; boron and compounds; coupling reactions; palladium and compounds; Suzuki reactions. 


\section{Introduction}

A general aim of transition metal-catalysed organic synthesis is carbon-carbon $(\mathrm{C}-\mathrm{C})$ bond formation. In this respect, the Pd-catalysed Suzuki-Miyaura (SM) coupling reaction $^{1}$ is one of the most efficient methods for the construction of $\mathrm{C}-\mathrm{C}$ bonds. Although several other methods (e.g. Kharash coupling, Negishi coupling, Stille coupling, Himaya coupling, Liebeskind-Srogl coupling and Kumuda coupling) are available for this purpose, the SM crosscoupling reaction which produces biaryls has proven to be the most popular in recent times. The preference for the SM cross-coupling reaction above the other Pd-catalysed crosscoupling reactions is not incidental. The key advantages of the SM coupling are the mild reaction conditions and the commercial availability of the diverse boronic acids that are environmentally safer than the other organometallic reagents. $^{2-9}$ In addition, the handling and removal of boron-containing byproducts is easy when compared to other organometallic reagents, especially in a large-scale synthesis. The cross-coupling reactions based on Grignard reagents have several drawbacks. These include ability of the Grignard reagents to attack the reactive functional groups present in the starting materials whereas the SM cross-coupling process tolerates a variety of functional groups in the starting partners. Although the disadvantages posed by Grignard reagents can be minimised by using tin compounds, the toxicity and the difficulties associated with the purification of certain tin compounds makes them a less attractive choice. The usage of other accessible methods is restrained, as the availability of the corresponding organometallic reagents is somewhat limited. Since biaryls and their homologues are found in several molecular frameworks (e.g. drugs, polymers, liquid crystalline materials and ligands for organometallic chemistry) there is a timely need for their development. The SM reaction has gained prominence in the last few years because the conditions developed for the cross-coupling reaction have many desirable features for large-scale synthesis and are amenable to the industrial synthesis of pharmaceuticals and fine chemicals. Several biaryls were prepared via the SM coupling reaction for structure/activity relationship (SAR) studies. Out of 24 potential agonists modelled by Eli Lilly, for example, nine compounds were synthesised by the SM coupling reaction and four derivatives had activity, ${ }^{10}$ at micromolar concentrations.

The SM cross-coupling reactions generally employ organic solvents such as THF and diethyl ether in the presence of $\mathrm{Pd}(\mathrm{II})$ or $\mathrm{Pd}(0)$ catalysts which are soluble in these solvents. Aryl halides (bromides or iodides) and triflates substituted with electron-withdrawing groups (EWGs) are suitable substrates for the cross-coupling reaction. Aryl triflates and sulphonates are regarded as the synthetic equivalents of aryl halides. Triflates are, however thermally labile, prone to hydrolysis and expensive to prepare. Aryl sulphonates are an attractive option because they are easily prepared from phenols, are more stable than triflates and are cheap and easily available starting materials. Recently, an efficient experimental procedure for the cross-coupling of arylboronic acids with aryl tosylates using $\mathrm{NiCl}_{2}\left(\mathrm{PCy}_{3}\right)_{2}$ as a catalyst was also reported and these aspects will be discussed later.
The SM cross-coupling reaction of various aryldiazonium tetrafluoborates prepared from anilides can proceed with arylboronic acids in the presence of a catalytic amount of $\mathrm{Pd}(\mathrm{OAc})_{2}$ or $\mathrm{Pd} / \mathrm{C}$ at ambient temperature and in the absence of base and phosphine ligand. ${ }^{11}$ Alcoholic solvents are essential for the success of the reaction whereas external bases are thought to be the key component in the SM coupling reaction. It is important to note that aryldiazonium salts are more reactive than aryl halides or aryl triflates in the cross-coupling reaction.

There is a large difference in the coupling rate of the iodoversus bromo-function in the SM cross-coupling reaction and this aspect has some advantages in organic synthesis. Multifunctional substrates, for example, can be used for a stepwise functionalisation process. In other words, this can lead to specificity of the reaction course for the iodinated carbon as long as the coupling partner is not used in excess. As an example, phenylboronic acid was found to have reacted with 4-bromochlorobenzene exclusively at the bromo-substituent giving 4-chlorobiphenyl in a $\mathrm{Pd}\left(\mathrm{PPh}_{3}\right)_{4}$ catalysed reaction. One of the bromo-substituents in 1,3,5tris(4-boromophenyl)benzene can be selectively replaced by phenylboronic acid giving 3,5-dibromobiphenyl in $67 \%$ yield. 1,3,5-Triiodobenzene on reaction with various boronic acids, however, gave the corresponding trisubstituted benzene derivatives in good yield.

The most commonly used base in the SM cross-coupling reaction is $\mathrm{Na}_{2} \mathrm{CO}_{3}$ but this is often ineffective with sterically demanding substrates. In such instances, $\mathrm{Ba}(\mathrm{OH})_{2}$ or $\mathrm{K}_{3} \mathrm{PO}_{4}$ has been used to generate good yields of the cross-coupling products. Other bases utilised in the SM coupling reaction include $\mathrm{Cs}_{2} \mathrm{CO}_{3}, \mathrm{~K}_{2} \mathrm{CO}_{3}$, $\mathrm{TlOH}, \mathrm{KF}$ and $\mathrm{NaOH}$. It is known that the base is involved in the coordination sphere of the palladium and the formation of the $\mathrm{Ar}_{-} \mathrm{PdL}_{2}-\mathrm{OR}$ from $\mathrm{Ar}-\mathrm{PdL} \mathrm{L}_{2}-\mathrm{X}$ is known to accelerate the transmetallation step.

There are some drawbacks with the Pd-mediated SM crosscoupling reaction. Only aryl bromides and iodides can be used, as the chlorides only react slowly. Some of the recent results to overcome this problem will be addressed in the latter part of this review. Byproducts such as self-coupling products, coupling products of phosphine-bound aryls, are often formed. The most frequently used catalyst, $\mathrm{Pd}\left(\mathrm{PPh}_{3}\right)_{4}$, suffers from this drawback and the phenyl group of the $\mathrm{PPh}_{3}$ becomes incorporated in the products giving scrambled derivatives. A bulky phosphine ligand $\left(o-\mathrm{MeOC}_{6} \mathrm{H}_{4}\right)_{3} \mathrm{P}$ is sufficient to retard this type of side-reactions and deliver high yields of the desired product. Under oxygen-free conditions, homocoupling products can be avoided and, in order to remove the dissolved oxygen, it is desirable to de-gas the solvents by a suitable method. Saponification of esters, racemisation of optically active compounds or Aldol condensation of carbonyl derivatives are some typical problems encountered during the SM cross-coupling reaction. Fluoride salts such as $\mathrm{CsF}$ and $\mathrm{Bu}_{4} \mathrm{NF}$ (2-3 equiv.) are useful for base-sensitive substrates.

\section{Scope of the review}

The availability of several thousand publications in the 
literature clearly indicates the impact of the SM coupling reaction in organic synthesis in the past two decades (1981-2001). Several excellent reviews are available to cover the work before $1998 .^{2-9}$ Since then, various groups have reported significant contributions in this area and our review aims to give an overview of the recent developments from 1999 to late 2001. We have included earlier references where these are necessary for the discussion. During the last 3-4 years, a number of advances have appeared with reference to the catalyst development and, additionally, heterocyclic frameworks have been modified by the application of this methodology. For uses of the SM coupling reaction in polymer synthesis, the reader is referred to a specialised review article. ${ }^{12}$ In Sections 6, 7, 8 and 10, we will discuss the synthesis of a range of natural and non-natural products (dendrimers, porphyrins and unusual amino acids and peptides) using the SM coupling reaction as a key step. Since there is a large amount of literature which has appeared in the past few years it has not been possible to include all the references available, but a sincere attempt has been made to include as many examples as possible. Examples from the patent literature, however, are not covered. Although various authors have reported several examples of a particular methodology, we have chosen one or two examples to illustrate the point.

\section{Preparation of boronic acids and their derivatives}

Several approaches for the syntheses of boronic acids have been reported, most of which are based on the reaction of trialkylborates with Grignard or organolithium reagents. ${ }^{13}$ Boronic acids can also be prepared by the hydroboration of alkenes and alkynes and haloboration of terminal alkynes.

The exchange reactions between borane in THF and arylmetallic derivatives lead to arylboronic acids, but with a very low yield $(9-60 \%) .{ }^{14}$ This is due to the formation of other organoborane derivatives. Aryltrialkyltin compounds react with borane in THF to give mixtures of trialkyltin hydrides and arylboranes, which on hydrolysis give the arylboronic acid in high yields (Scheme 1).

$\mathrm{R}_{3} \mathrm{SnAr}+\mathrm{BH}_{3} \stackrel{\mathrm{THF}}{\longrightarrow} \mathrm{R}_{3} \mathrm{SnH}+\mathrm{ArBH}_{2} \stackrel{\mathrm{H}_{2} \mathrm{O}}{\longrightarrow} \mathrm{ArB}(\mathrm{OH})_{2}$

Scheme 1.

It has been found that the addition of tetraalkoxydiboranes to alkynes gives cis-diboroalkenes in the presence of platinum(0) complexes. ${ }^{15}$ Since alkoxyboranes are thermally stable and are easily handled in air, the reagent was

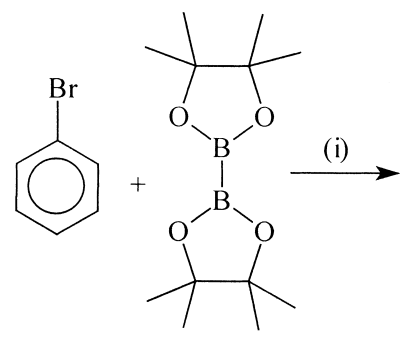

1

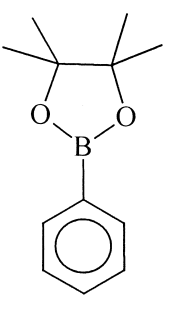

2
Scheme 2. (i) $\mathrm{PdCl}_{2}$ (dppf), KOAc, DMSO. used as efficient boron nucleophile for the cross-coupling reaction with organic halides.

Pd-catalysed cross-coupling reactions of bis(pinacolato)diboron 1 and aryl halides, represents the first one-step procedure $^{16}$ for preparing arylboronic esters 2 from aryl halides (Scheme 2). The less reactive chloroarenes are also efficient precursors to boronic acid derivatives in the presence of $\mathrm{Pd}(\mathrm{dba})_{2}$ and $\mathrm{PCy}_{3}$ (Scheme 3$) .{ }^{17}$ The catalyst can also be effective for carrying out the coupling reaction of the less reactive aryl bromide or triflates bearing electrondonating substituents under mild conditions.

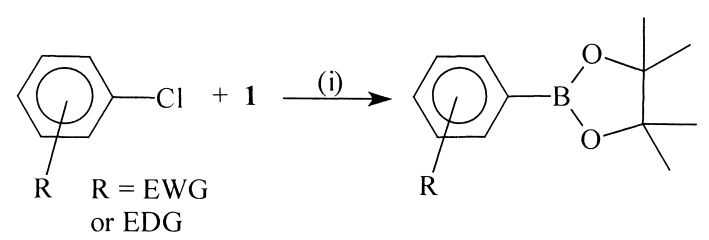

Scheme 3. (i) $\mathrm{Pd}(\mathrm{dba})_{2}, \mathrm{PCy}_{3}, \mathrm{KOAc}$, dioxane, $80^{\circ} \mathrm{C}$.

Aryldiazonium tetrafluoroborate salts such as $\mathbf{3}$ are highly attractive synthetic alternatives to the corresponding halides and triflates and can be prepared from the relatively inexpensive and readily available anilines. They are more reactive than the halides or triflates in the cross-coupling reaction. Recently, Strongin and Willis ${ }^{18}$ have demonstrated the synthesis of the arylboronic ester from the aryldiazonium tetrafluoroborate salt $\mathbf{3}$ as the substrate (Scheme 4).

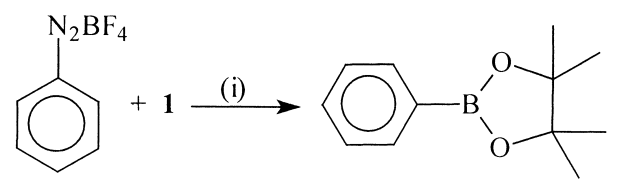

3

Scheme 4. (i) $\mathrm{PdCl}_{2}$ (dppf), $\mathrm{KOAc}, \mathrm{MeOH}$.

Alkanes are the most abundant but the least reactive molecules. Hartwig and co-workers ${ }^{19}$ have developed a Rhcatalysed [e.g. $\mathrm{Cp}{ }^{*} \mathrm{Rh}\left(\eta^{4}-\mathrm{C}_{6} \mathrm{Me}_{6}\right)$ ] reaction for the formation of linear alkylboranes from the commercially available borane reagent $\mathbf{1}$ under thermal conditions (Scheme 5).

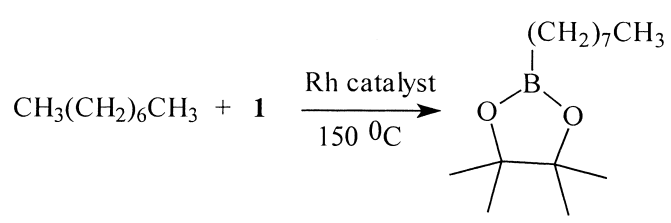

Scheme 5.
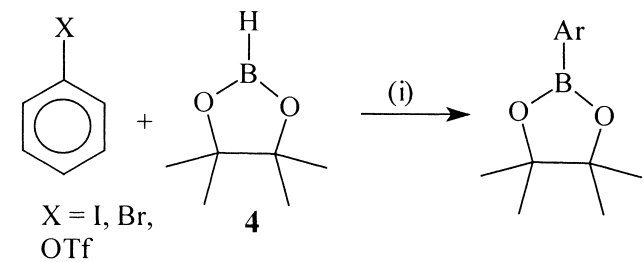

Scheme 6. (i) $\mathrm{PdCl}_{2}$ (dppf), $\mathrm{Et}_{3} \mathrm{~N}$. 
Masuda and co-workers ${ }^{20}$ have recently prepared arylboronic esters from the dialkoxyhydroborane $\mathbf{4}$ and an aryl halide or triflate (Scheme 6) using a Pd-catalysed coupling reaction. Dialkoxyboranes are more readily available than the tetraalkoxydiborane reagents. This methodology possesses several advantages, as a wide range of boronic esters can easily be prepared.

The requirement of aryl halide or triflate precursors proved to be problematic, however, when heavily functionalised boronic ester product is required. In this regard, a novel and flexible approach to highly substituted isoxazole boronic ester $7^{21}$ through a key [3+2]-cycloaddition reaction of nitrile oxides 5 with alkynylboronates $\mathbf{6}$ has been developed (Scheme 7). The cycloaddition technique not only permits the regioselective formation of highly substituted isoxazole products but also circumvents the limitation associated with the preparation of diaryl- or dialkyl- substituted isoxazoles through the employment of an alkyne substrate.

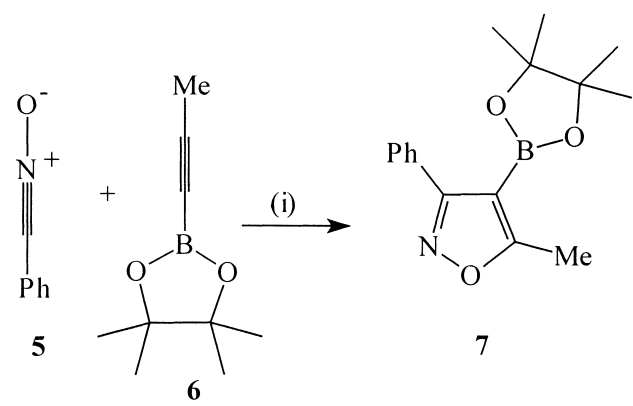

Scheme 7. (i) $\mathrm{Et}_{2} \mathrm{O}$, reflux.

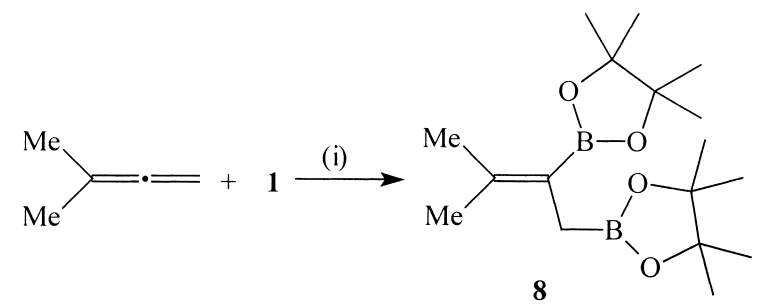

Scheme 8. (i) $\mathrm{Pd}(\mathrm{dba})_{2}$, aryl or alkenyl iodide, toluene $80^{\circ} \mathrm{C}$.

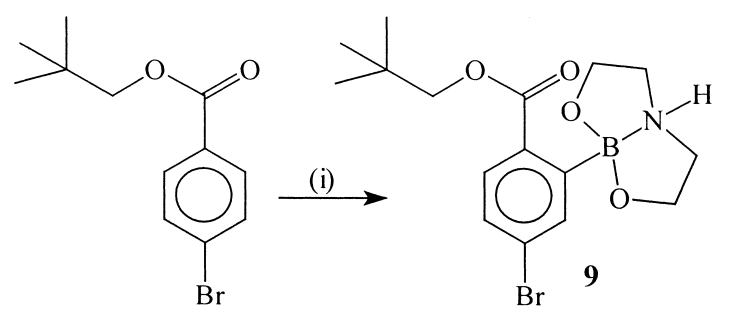

Scheme 9. (i) LDA, B(OiPr $)_{3}$, THF, diethanolamine.

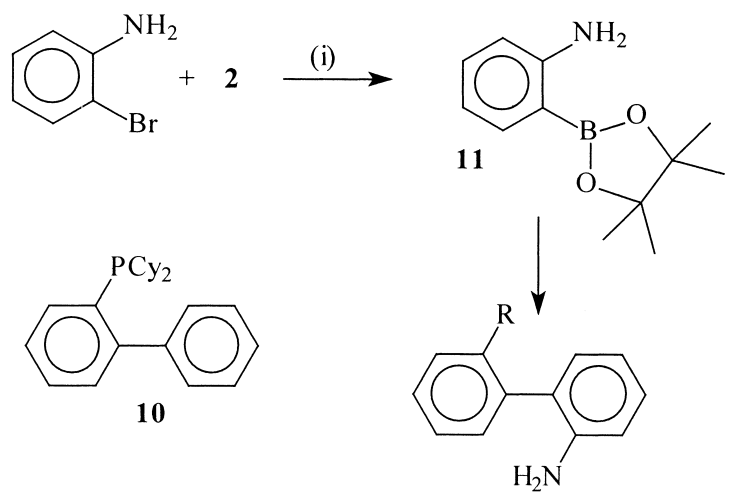

Scheme 11. (i) $\mathrm{Pd}(\mathrm{OAc})_{2} / 4, \mathrm{Et}_{3} \mathrm{~N}$, dioxane.

Cheng and co-workers ${ }^{22}$ have demonstrated the first phosphine-free Pd-complexes together with an alkenyl or aryl iodide as a very efficient catalyst for 1,2-diboronation of allenes such as $\mathbf{8}$ (Scheme 8). This reaction is highly regioand stereoselective. Monosubstituted allenes afford diboronation products with $Z$-stereochemistry. It was observed that an iodine source was needed for the success of the reaction. The reaction proceeds via a mechanism involving the oxidative addition of an I-B bond to the Pd center instead of $\mathrm{B}-\mathrm{B}$ bond to the metal.

Caron and Hawkins ${ }^{23}$ have recently applied the concept of directed ortho-metallation of arenes in which the neopentyl ester acts as an efficient ortho directing group for the ortho metallation of arenes using lithium diisopropylamide (LDA) as a base and triisopropylborate $\mathrm{B}(\mathrm{O} i \mathrm{Pr})_{3}$, as an in situ trap. The crude boronic acid was complexed with diethanolamine to deliver 9 (Scheme 9). This methodology allows the preparation of a new class of boronic acids with orthocarbonyl substituents.

By using the above concept, Vedso and co-workers ${ }^{24}$ found that lithium 2,2,6,6-tetramethylpiperidide (LTMP) and $\mathrm{B}(\mathrm{O} i \mathrm{Pr})_{3}$ is an excellent combination for preparing orthosubstituted arylboronic esters (Scheme 10) in high yields. These boronic esters are stable, non-hygroscopic and easy to characterise.

Baudoin $^{25}$ has reported an efficient method for the borylation of ortho-substituted phenyl bromides or iodides (Scheme 11) using the phosphine ligand 10. A one-pot SM cross-coupling reaction of the compound $\mathbf{1 1}$ with ortho substituted phenyl halides gave the sterically hindered and synthetically useful $2,2^{\prime}$-biphenyl compounds.

Recently, much attention has been focussed on alternative modes of reactivity of boronic acids and on extending their synthetic utility. Falck and co-workers have developed a

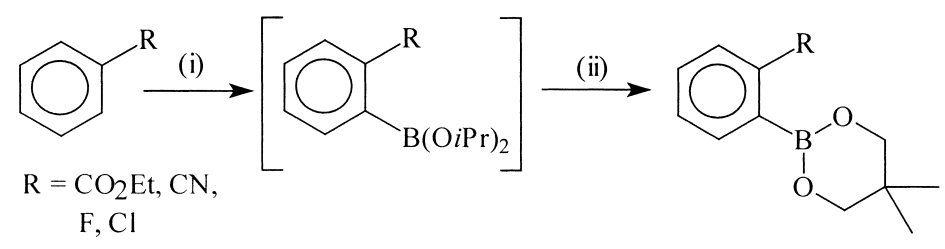

Scheme 10. (i) LTMP, B(OiPr $)_{3}$, THF, $-78^{\circ} \mathrm{C}$. (ii) 2,2-dimethyl-1,3-propanediol, toluene, RT. 


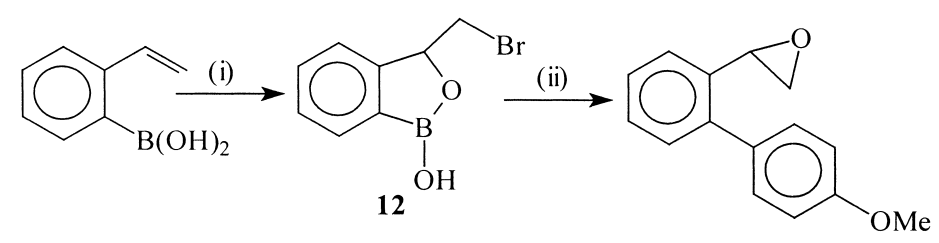

Scheme 12. (i) NBS, THF, $\mathrm{H}_{2} \mathrm{O}$. (ii) $p-\mathrm{MeOC}_{6} \mathrm{H}_{4} \mathrm{Br}, \mathrm{Pd}\left(\mathrm{PPh}_{3}\right)_{4}, \mathrm{DMF}, \mathrm{K}_{3} \mathrm{PO}_{4}$.

facile formation of bromo-boronolactones 12 (Scheme 12$)^{26}$ starting from ortho-alkenylarylboronic acids and these lactones can undergo the SM cross-coupling reaction to give epoxybiphenyls.

\section{Catalyst development}

A general catalytic cycle for the cross-coupling of organometallic reagents with organic halides (Fig. 1) involves the oxidative addition of organic halides to the $\operatorname{Pd}(0)$ complex to form the organopalladium halide $(\mathrm{R}-\mathrm{M}-\mathrm{X})$, and is often the rate-determining step in the catalytic cycle. This step is followed by transmetallation with main-group organometallics $\left(\mathrm{R}^{\prime} \mathrm{M}^{\prime}\right)$ to provide the diorganopalladium complex $\left(\mathrm{R}-\mathrm{M}-\mathrm{R}^{\prime}\right)$, which can undergo a reductive elimination, leading to carbon-carbon bond formation and regeneration of the catalyst. Various phosphine ligands are effective in stabilising the $\operatorname{Pd}(0)$ species during the cross-coupling reaction of arylboronic acids. The crucial difference between organoborane crosscoupling catalytic cycle (Fig. 2) and the general catalytic cycle (Fig. 1) is the displacement of halide ion from $\mathrm{R}-\mathrm{Pd}-\mathrm{X}$ to give the more reactive organopalladium alkoxide $(\mathrm{R}-\mathrm{Pd}-\mathrm{OR})$ or organopalladium hydroxide $(\mathrm{R}-\mathrm{Pd}-\mathrm{OH})$ depending on the base used.

Aryl and alkenyl bromides, iodides and triflates are often

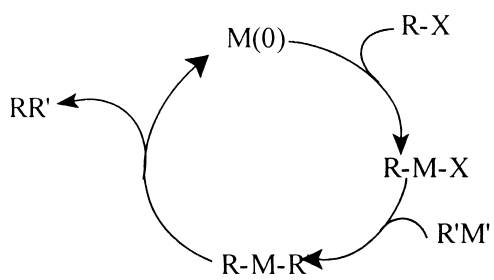

Figure 1. Catalytic cycle for cross-coupling of organic halides and organometallics.

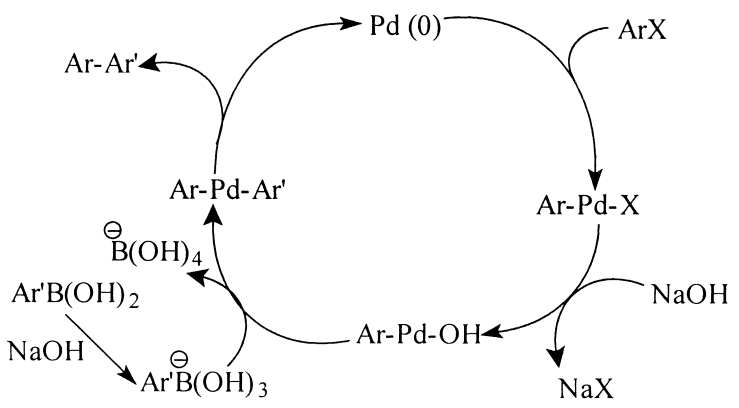

Figure 2. Catalytic cycle for cross-coupling of organic halides and organoboranes. used as substrates in the SM reaction. In order to extend the scope and utility of the SM reaction to the inexpensive and readily available aryl chlorides as viable starting materials for the synthesis of fine chemicals and functional materials, a great deal of research activity has been undertaken in recent times. The decreased reactivity of the aryl chlorides in the Pd-catalysed reaction has been attributed to their reluctance towards oxidative addition to $\operatorname{Pd}(0)$. Recently, several catalysts/ligands (Fig. 3) have been found to facilitate aryl chlorides in the SM cross-coupling reaction and some of these results are discussed here.

\subsection{SM Coupling reactions with aryl chlorides}

Herrmann and co-workers ${ }^{27}$ have shown that 4-chloroacetophenone and phenylboronic acid can be coupled with $1.0 \mathrm{~mol} \%$ of the Pd(II)-heterocyclic carbene complex $\mathbf{1 3}$ at $130^{\circ} \mathrm{C}$, and they have subsequently used the mixed bicyclohexylphosphine complex 14 to catalyse the reaction of phenylboronic acid with various chlorobenzene derivatives (Scheme 13). ${ }^{28}$ They found that, with deactivated aryl chlorides, $\mathrm{Cs}_{2} \mathrm{CO}_{3}$ is a much more effective base than $\mathrm{K}_{2} \mathrm{CO}_{3}$. Another heterocyclic carbene complex of type $\mathbf{1 5}$ has been used for the SM coupling of aryl chlorides, with turnover frequencies up to $552 .{ }^{29}$

Trudell and co-workers ${ }^{30}$ have found that the SM crosscoupling reaction of the arylboronic acids with nonactivated aryl chlorides occurs at $80^{\circ} \mathrm{C}$ in high yields if catalytic amounts of $\operatorname{Pd}_{2}(\mathrm{dba})_{3}$ and the sterically crowded imidazolium salt 16 are combined with $\mathrm{Cs}_{2} \mathrm{CO}_{3}$ in dioxane. Both sterically hindered and electron-rich aryl chlorides were found to couple with arylboronic acids in high yields. They later showed that a combination of $\mathrm{Pd}(\mathrm{OAc})_{2}$ and the bis-imidazolium salt $\mathbf{1 7}$ gave an air-stable catalytic system, amenable to large-scale synthesis and giving a high-yielding cross-coupling reaction of aryl chlorides with arylboronic acids. ${ }^{31}$

Shen $^{32}$ found that $\mathrm{Pd}\left(\mathrm{PCy}_{3}\right)_{2} \mathrm{Cl}_{2}$ or $\mathrm{Pd}(\mathrm{OAc})_{2} /$ dppp catalyse the $\mathrm{SM}$ reactions with a number of aryl chlorides containing EWGs. The phenylboronic acid failed to react with aryl chlorides that lacked electron-withdrawing substituents, and aryl chlorides that had substituent in the meta position were less reactive than those with an ortho- or para-substituent.

Fürstner ${ }^{33}$ has used $\mathrm{Pd}(\mathrm{OAc})_{2}$ and the sterically hindered imidazolium salt 18 as the pre-catalyst mixture for the efficient cross-coupling of aryl chlorides with 9R-9-BBN (9-substituted-9-borabicyclo[3.3.1]nonane) derivatives $(\mathrm{R}=$ alkyl, aryl, alkynyl, cyclopropyl) in the presence of $\mathrm{KOMe}$ as the base (Scheme 14). This protocol is applicable to electron-poor and electron-rich substrates with equal ease. 


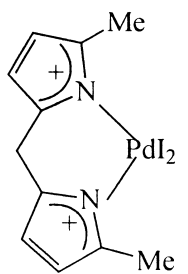

13<smiles></smiles>

14

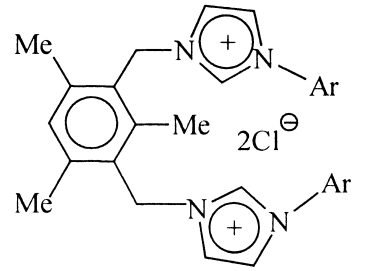

17<smiles>[R]N1C=CN([R])C1[R]C1N([R])C=CN1[R]</smiles>

15<smiles>Cc1cc(C)c(-n2cc[n+](-c3c(C)cc(C)cc3C)c2)c(C)c1</smiles>

16

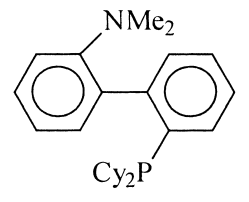

20

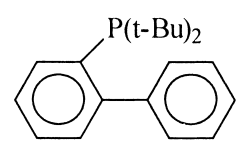

21<smiles></smiles>

18

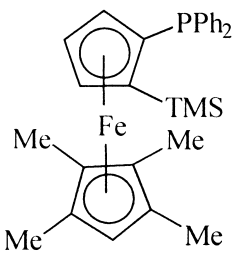

19

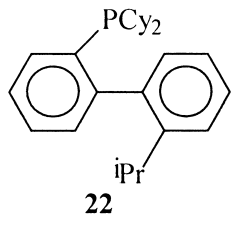

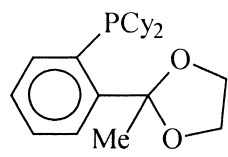

24

23

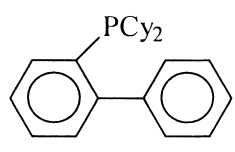

10

Figure 3. Partial list of Pd catalysts and/or ligands used for SM cross-coupling of aryl chlorides.

Littke and Fu reported that $\mathrm{P}(t-\mathrm{Bu})_{3}$ is an efficient ligand for the Pd-catalysed reactions of various aryl chlorides with arylboronic acids in dioxane $/ \mathrm{Pd}_{2}(\mathrm{dba})_{3} / \mathrm{Cs}_{2} \mathrm{CO}_{3}$ (Scheme 15). $\mathrm{P}(t-\mathrm{Bu})_{3}$ is however pyrophoric and needs

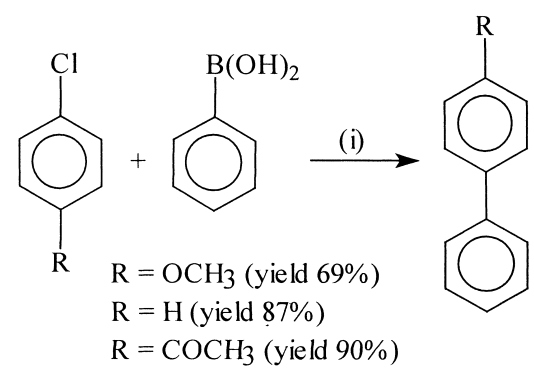

Scheme 13. (i) 14 (1.0 mol\% $\mathrm{Pd}), \mathrm{K}_{2} \mathrm{CO}_{3}$ or $\mathrm{Cs}_{2} \mathrm{CO}_{3}$, xylene, $130^{\circ} \mathrm{C}$.<smiles>CCCCCCCCCCCCCCCCCCCCCCCCCCC</smiles>

Scheme 14. (i) $\operatorname{Pd}(\mathrm{OAc})_{2}(2 \mathrm{~mol} \%), \mathbf{1 8}$, THF, reflux. special precautions while handling. ${ }^{34}$ The high activity of $\mathrm{P}(t-\mathrm{Bu})_{3}$ was attributed to the electron-rich nature and the steric bulk of the ligand. The same group later reported that the activated aryl chlorides undergo the SM cross-coupling reaction at $\mathrm{RT}$ in good yields by using $\mathrm{Pd}_{2}(\mathrm{dba})_{3} / \mathrm{P}(t-\mathrm{Bu})_{3}$ as a source of $\mathrm{Pd}$, and $\mathrm{KF}$ as the base (Scheme 16) (S5 $^{35}$ and,

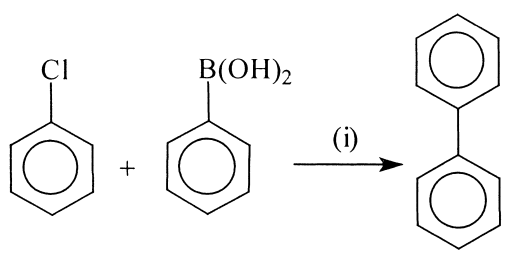

Scheme 15. (i) $\mathrm{Pd}_{2}(\mathrm{dba})_{3}(1.5 \mathrm{~mol} \%), \mathrm{P}(t-\mathrm{Bu})_{3}, \mathrm{Cs}_{2} \mathrm{CO}_{3}$, dioxane, $80-90^{\circ} \mathrm{C}$.

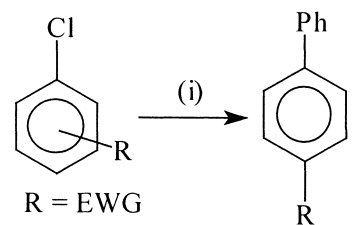

Scheme 16. (i) $\mathrm{PhB}(\mathrm{OH})_{2}, \mathrm{Pd}_{2}(\mathrm{dba})_{3}(0.5 \mathrm{~mol} \%), \mathrm{P}(t-\mathrm{Bu})_{3}, \mathrm{KF}$, THF, RT. 
additionally, selective cross-coupling by $\mathrm{Pd}_{2}(\mathrm{dba})_{3} / \mathrm{P}(t-\mathrm{Bu})_{3}$ of aryl chlorides in preference to aryl triflates was observed. A high ton (turnover number) (10 000) has been achieved in the SM reaction of 2-chlorobenzonitrile with $p$-tolylboronic acid at $90^{\circ} \mathrm{C}$. Sterically hindered aryl chlorides can react efficiently with mono- and di-ortho-substituted arylboronic acids to form the hindered biaryls with excellent yields at $60-90^{\circ} \mathrm{C}$ using a $\mathrm{Pd}_{2}(\mathrm{dba})_{3} / \mathrm{P}(t-\mathrm{Bu})_{3}$ or $\mathrm{Pd}_{2}(\mathrm{dba})_{3} / \mathrm{PCy}_{3}$ catalyst system. They also discovered that the air-stable triarylphosphine 19 catalyses the SM reaction of a wide range of aryl chlorides at RT in uniformly good yield. ${ }^{36}$

Buchwald and co-workers ${ }^{37}$ have found that a combination of $\mathrm{Pd}(\mathrm{OAc})_{2}$ and 2-dicyclohexylphosphanyl-2'-dimethylaminobiphenyl $\mathbf{2 0}$ is a highly efficient catalyst system for the SM reaction of aryl chlorides. It is interesting to note that the SM reaction of phenylboronic acid derivatives with aryl chlorides, including those that are substituted by electron-donating and $o$-methyl substituents, could be carried at RT with a 1.0-2.0 mol\% Pd catalyst. In some instances, it was shown that the amount of catalyst loading can be decreased to $0.5 \mathrm{~mol} \%$ if the temperature was raised to $100^{\circ} \mathrm{C}$. Additionally, $\mathrm{Pd}(\mathrm{OAc})_{2}$ in combination with the air-stable ligand 20 catalyses the reaction of $n$-hexyl-9-BBN and 4-chloroanisole at $50^{\circ} \mathrm{C}$ (Scheme 17). ${ }^{38}$
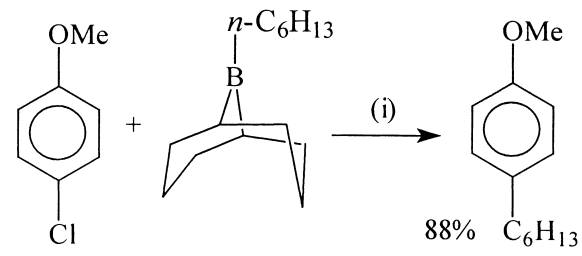

Scheme 17. (i) $\mathrm{Pd}(\mathrm{OAc})_{2}(2 \mathrm{~mol} \%), 20, \mathrm{CsF}$, dioxane, $50^{\circ} \mathrm{C}$.

The combination of $\mathrm{Pd}(\mathrm{OAc})_{2}$ and the biphenylphosphine ligand $\mathbf{2 1}$ gives an unusually mild catalyst for the SM reaction of both aryl chlorides and bromides. With a relatively low catalyst loading $(0.5-1.5 \mathrm{~mol} \% \mathrm{Pd})$, it is possible to couple a large variety of aryl chlorides with phenylboronic acids at RT (Scheme 18). ${ }^{38}$ The proper selection of the solvent and base is critical for the success of this process. A wide range of electron-rich and EWGs were tolerated on both partners, the $o$-substituted aryl chlorides and the arylboronic acid derivatives.

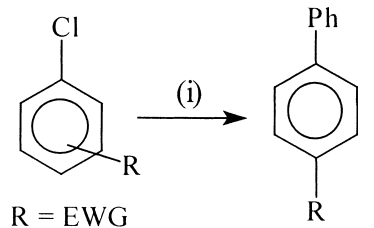

Scheme 18. (i) $\mathrm{PhB}(\mathrm{OH})_{2}, \mathrm{Pd}(\mathrm{OAc})_{2}(0.5-1.5 \mathrm{~mol} \%), 21, \mathrm{KF}, \mathrm{THF}, \mathrm{RT}$.

The above reaction conditions are not generally suitable for the preparation of biaryls with more than one $o$-substituent. In this respect, the ligands $\mathbf{1 0}$ and $\mathbf{2 2}$ have been employed for the coupling reaction in toluene/ $\mathrm{K}_{3} \mathrm{PO}_{4}$ (Scheme 19). ${ }^{37,39}$ Additional experiments indicated that the SM crosscoupling reaction of the aryl chloride could be carried out at a low catalyst loading with the appropriate choice of ligand. A 1000 ton has been obtained for the reaction of

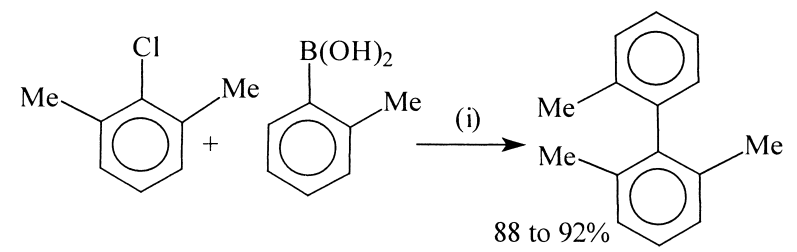

Scheme 19. (i) $\mathrm{Pd}(\mathrm{OAc})_{2}, 10$ or $22, \mathrm{~K}_{3} \mathrm{PO}_{4}$, toluene, $100^{\circ} \mathrm{C}$.

4-chlorotoluene and phenylboronic acid with $\mathrm{Pd}(\mathrm{OAc})_{2} / \mathbf{2 1}$, and a 2000 ton was achieved with the ligand 10. With activated 4-chloroacetophenones, a 5000 ton was obtained with the ligand $\mathbf{1 0}$.

A combination of several factors is responsible for the unique success of these ligands: (i) their electron-rich nature enhances the rate of oxidative addition, (ii) the basic phosphine binds tightly to the complex to prevent precipitation of the Pd catalyst, and (iii) their steric bulk enhances the rate of reductive elimination. The presence of the biphenyl moiety brings air stability to the ligand and thereby enhances the rate of reductive elimination as well as stabilising the catalyst by interacting with the Pd.

Kočovský et al. have observed a dramatic acceleration in the SM coupling of 4-chlorobenzaldehyde with phenylboronic acid at $\mathrm{RT}$ in the presence of $\mathrm{Pd}(\mathrm{OAc})_{2} / \mathbf{2 3}$ and either $\mathrm{CsF}$ or $\mathrm{Cs}_{2} \mathrm{CO}_{3}$ as the base. ${ }^{40}$

Guram and co-workers have shown that a combination of the phenyl backbone-derived $\mathrm{P}-\mathrm{O}$ ligand $\mathbf{2 4}$ and $\mathrm{Pd}(\mathrm{dba})_{2}$ gives an efficient catalyst system for the SM cross-coupling of a variety of aryl chlorides and arylboronic acids using $\mathrm{CsF} /$ dioxane $/ 100-110^{\circ} \mathrm{C}$ conditions. ${ }^{41}$ This efficient catalytic system has also permitted $o$-substitution on one or both coupling partners and electron-rich and EWGs were tolerated. $^{42}$

The use of the catalytic cross-coupling reaction for the preparation of aryl-functionalised heterocycles with multiple applications is increasing at an accelerating phase. Unlike the aryl chlorides, heteroaryl chlorides undergo the standard SM cross-coupling reaction with the commonly used tetrakis(triphenylphosphine)palladium $(0)\left[\mathrm{Pd}\left(\mathrm{PPh}_{3}\right)_{4}\right]$ catalyst. Incorporation of the nitrogen atom into the benzene ring decreases the energy required for the oxidative addition. When this energy is sufficiently decreased, Pd catalysts having less electron-donating ligands are able to insert into the $\mathrm{C}-\mathrm{Cl}$ bond. Recently, arylpyridine ${ }^{43}$ and other related nitrogen-containing heterocycles ${ }^{44-46}$ were prepared from the corresponding chlorinated compounds in good yields by means of the traditional SM cross-coupling reaction conditions, avoiding the multistep synthetic sequence.

\subsection{SM Cross-coupling reactions by palladacyclic complexes}

In view of the industrial applications of $\mathrm{Pd}$ catalysis, improved and highly active catalysts have been reported for the SM cross-coupling reaction by different groups. Unfortunately, the major drawback of these ligand systems is the difficulty in achieving the rather involved synthetic 


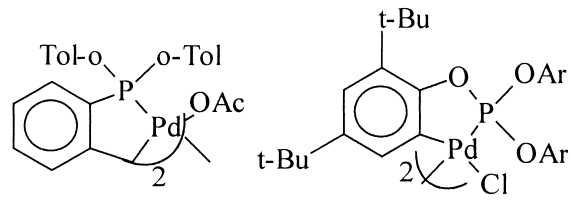

25<smiles></smiles>

28

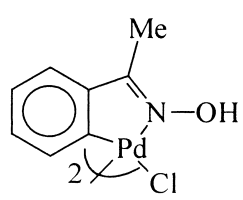

31
26<smiles>CN1Cc2ccccc2[Te]1(CC(C)(C)C)C(F)(F)F</smiles>

29

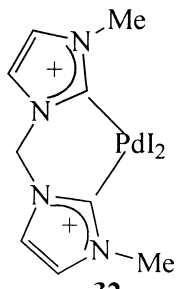

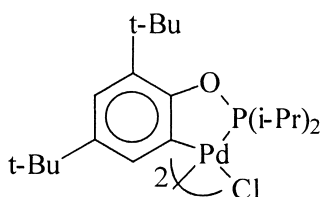

27

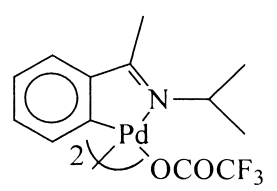

30

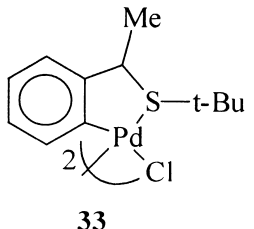

33

Figure 4. Partial list of palladacyclic complexes.

sequence. Palladacycle catalysts where the ligand is in a position to coordinate to the metal center through both a donor atom and a metallated carbon have shown considerable promise. Different palladacycles used in the SM crosscoupling reaction are shown in Fig. 4.

In 1995 , Beller and co-workers ${ }^{47}$ reported the use of the metallated tris(2-methylphenyl)phosphinepalladium(II) $\mathbf{2 5}$ as an efficient catalyst for the SM reaction. Bedford and co-workers later prepared the ortho-metallated $\mathrm{Pd}(\mathrm{II})$ triarylphosphite complex $\mathbf{2 6}$ which proved to be an extremely active catalyst for the SM cross-coupling reaction, giving a very high ton of 1000000 at $110^{\circ} \mathrm{C}$. The complex 25 gave a ton of 74000 at a higher temperature of $130^{\circ} \mathrm{C}$ over $16 \mathrm{~h}$. The complex 26 showed an extremely high activity with both electronically activated and deactivated aryl bromides-considerably higher than the activity reported for $\mathbf{2 5}$. $^{48}$

Palladacyclic phosphinite complexes of the type $27^{49}$ and $\mathbf{2 8}^{50}$ are suitable catalysts for the coupling of deactivated and sterically hindered aryl bromides, as they are comparatively inexpensive, easily synthesised and give high conversions at extremely low concentrations. The low-cost tricyclohexylphosphine adduct of a Pd complex with an ortho-metallated N-donor ligand $\mathbf{2 9}^{51}$ showed the highest activity in the SM coupling of aryl chlorides, regardless of whether the substrates are electron-rich or electron-poor. An additional high activity was observed with the catalyst formed in situ and when the reaction was carried out in the air. The phosphine free-imine complex 30,52 the oxime palladacycle $\mathbf{3 1}^{53}$ and the imidazole palladacycles $\mathbf{3 2}^{53}$ are excellent catalysts for the SM reaction leading to a high ton (100-1 000 000) with non-activated aryl bromides. The catalyst is both air and thermally stable. The sulphurcontaining palladacycle $\mathbf{3 3},{ }^{54}$ stable to air and water, can be prepared easily and effectively promotes the SM coupling of aryl bromides and chlorides at RT in excellent isolated yields $(>90 \%)$ to give the biaryl products. For reactions involving electron-rich and electron-neutral aryl chlorides, however, low conversions have been achieved, even at higher temperatures. The phosphine-free palladacycle $\mathbf{3 3}$ also efficiently promotes the cross-coupling reaction with sterically demanding substrates. The most efficient catalyst precursor generally contains one $t$-BuS moiety bonded to the $\mathrm{Pd}$ atom and a lower concentration of the palladacycle catalyst could be employed, leading to a ton of 37000 . The use of $n \mathrm{Bu}_{4} \mathrm{~N}^{+} \mathrm{Br}^{-}$as a promoter increases the crosscoupling product.

\subsection{SM Cross-coupling reactions with other novel palladium catalysts}

Most of the SM cross-coupling reactions make use of a significant amount of expensive basic phosphine ligands or carbene-Pd complexes. Beller and co-workers ${ }^{55}$ have shown that the SM reaction of aryl bromides was efficiently catalysed by palladium/phosphite complexes generated in situ (Scheme 20). This process tolerates various functional groups and a catalyst ton of 820000 has been obtained even with deactivated aryl bromides. It was further demonstrated that the complex could efficiently catalyse the SM reaction of aryl chlorides. The exact combination of the base,

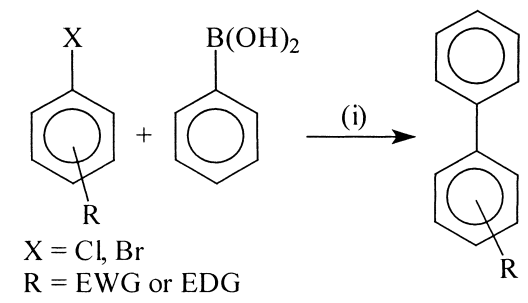

Scheme 20. (i) $\mathrm{Pd}(\mathrm{OAc})_{2}, \mathrm{P}(\mathrm{OR})_{3}$, toluene, base, $120^{\circ} \mathrm{C}$. 
additive (e.g. $\mathrm{CaF}_{2}$ ) and sterically hindered palladium/ phosphite ratio is crucial for the success of the crosscoupling reaction. The phosphite ligands are advantageous when compared to phosphines due to economic and operational aspects.

The same group has used 1,6-dienes stabilized by $\mathrm{Pd}(0)-\mathrm{PR}_{3}$ $\left(\mathrm{R}=2,4\right.$-di-tert-butylphenyl or isopropyl) complexes ${ }^{56}$ as efficient catalysts for the SM cross-coupling of aryl chlorides as compared with the traditional $\mathrm{Pd}(\mathrm{II})-\mathrm{PR}_{3}$ precatalysts. This catalyst was generated in situ and can be used in low-Pd concentrations (0.05 mol\% Pd) (Scheme 21). Better results were achieved with the 1,6-diene complex 34 containing the 'Buchwald ligand'. The resulting catalyst has one of the highest ton reported for the SM cross-coupling reaction of non-activated aryl chlorides. These complexes can be fine tuned to improve their catalytic properties.

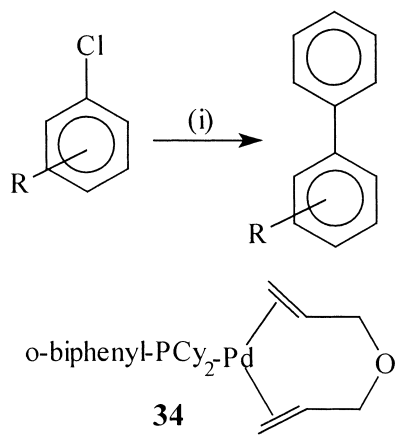

Scheme 21. (i) $\mathrm{PhB}(\mathrm{OH})_{2}, 34(0.05 \mathrm{~mol} \%), \mathrm{K}_{3} \mathrm{PO}_{4}, \mathrm{KF}, \mathrm{THF}, 100^{\circ} \mathrm{C}$.

Santelli and co-workers have reported the tetradentate ligand, cis,cis,cis-1,2,3,4-tetrakis(diphenylphosphinomethyl)cyclopentane (tedicyp) 35 (Fig. 5) which in combination with $\left[\mathrm{PdCl}\left(\mathrm{C}_{3} \mathrm{H}_{5}\right)\right]_{2}$ produces an efficient catalyst for the SM cross-coupling reactions of sterically hindered aryl bromides, ${ }^{57-59}$ heteroaryl bromides ${ }^{60}$ and activated aryl chlorides ${ }^{61}$ with arylboronic acids in good yields. In the tedicyp ligand 35, four diphenylphosphino groups are stereospecifically bound to the same face of a

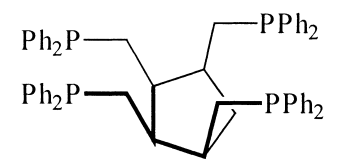

35

Figure 5. cis, cis,cis-1,2,3,4-Tetrakis(diphenylphosphinomethyl)cyclopentane. cyclopentane ring. The presence of the four phosphine groups close to the metal center seems to increase the coordination of the ligand to the metal and therefore to increase the stability of the catalyst system. The exceptionally high ton $(28000000)$ is attributed to a correct balance of steric and electronic factors. In some cases, the SM reaction can be performed with as little as $0.000001 \%$ catalyst loading. 57,60

\subsection{Nickel-catalysed SM cross-coupling reactions}

As seen from the preceding discussions, several efficient Pd catalyst precursors have been developed that allow aryl iodides, bromides, triflates and chlorides to be effectively cross-coupled with arylboronic acids under mild reaction conditions. $\mathrm{Ni}(0)$ catalysts have also been successfully employed for the SM reaction of the less reactive aryl chlorides and mesitylates. The most frequently used preformed $\mathrm{Pd}(0)$ complex in the SM cross-coupling reaction is $\mathrm{Pd}\left(\mathrm{PPh}_{3}\right)_{4}$. A number of byproducts and/or scrambled products are, however, formed with this catalyst (Scheme 22). The Ni catalysts have many advantages over the $\mathrm{Pd} /$ phosphine complexes and, for example, they are more reactive and often cheaper than the $\mathrm{Pd}$ complexes. Ni-Catalysed reactions are more specific and are complementary to their Pd analogues. Their air stability, ease of preparation and separation of the catalyst mixture from the product at the end of the reaction sequence are some of the advantages of the $\mathrm{Ni}$ catalysts. To prepare sterically hindered biaryls useful in natural product synthesis, Ni complexes have been found to be better catalysts than their $\mathrm{Pd}$ counterparts because $\mathrm{Ni}$ is smaller in size compared to $\mathrm{Pd}$. Consequently, Ni complexes can approach the aryl halides more easily than Pd during the oxidative addition step. In addition, the high catalytic activity of the $\mathrm{Ni}$ complexes ensures greater success in the cross-coupling reaction with various aryl chlorides having electron-rich and electron-poor substrates and there are no side reactions or scrambled products with the phosphine-bound aryls of the $\mathrm{Ni}$ catalysts. This is often unavoidable in the Pd-catalysed couplings and, additionally, the process is economical for the Ni-catalysed reactions, recycling of the catalyst not being required.

The $\mathrm{Ni}(0)$ complex, $\mathrm{Ni}\left(\mathrm{PPh}_{3}\right)_{4}$, is difficult to handle as it is air sensitive and highly toxic and it is therefore not commonly used in the SM cross-coupling reaction. Biaryl coupling of various aryl chlorides having electron-rich or electron-poor groups takes place in the presence of the $\mathrm{Ni}$ catalyst. The $\mathrm{Ni}(0)$ complex prepared in situ from $\mathrm{NiCl}_{2}$ (dppf) or $\mathrm{NiCl}_{2}\left(\mathrm{PPh}_{3}\right)_{2} / 2 \mathrm{PPh}_{3}$ and $n$ - $\mathrm{BuLi}$ (4 equiv.) is

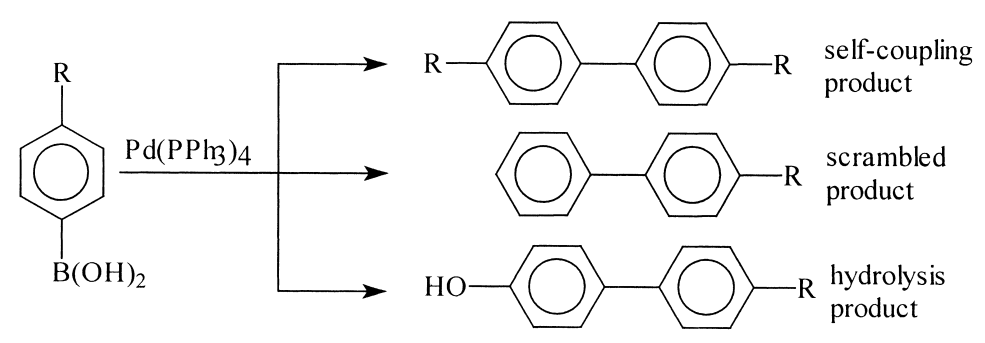

Scheme 22. Generally observed side-reactions with Pd-catalysed SM cross-coupling. 


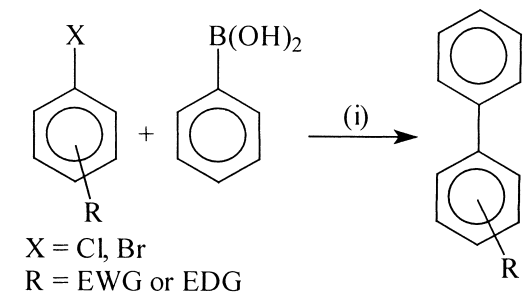

Scheme 23. (i) $\mathrm{NiCl}_{2}$ (dppf), $n$-BuLi, $\mathrm{K}_{3} \mathrm{PO}_{4}$, dioxane, base, $80^{\circ} \mathrm{C}$.

an efficient catalyst (Scheme 23). ${ }^{62-64}$ The use of additional phosphine ligand with $\mathrm{NiCl}_{2}(\mathrm{dppf})$ or $\mathrm{NiCl}_{2}\left(\mathrm{PPh}_{3}\right)_{2}$ has often been advantageous to obtain a high yield of the crosscoupling products.

Miyaura and co-workers ${ }^{65}$ have reinvestigated the Ni-catalysed cross-coupling reactions and have found that the more economical $\mathrm{NiCl}_{2}\left(\mathrm{PPh}_{3}\right)_{2} / 2 \mathrm{PPh}_{3}$ complex has a higher catalyst efficiency than the previous catalysts when the reaction was carried out in the presence of $\mathrm{K}_{3} \mathrm{PO}_{4} \cdot \mathrm{nH}_{2} \mathrm{O}$ suspended in toluene (Scheme 24). It is interesting to note that the reduction of the $\mathrm{Ni}(\mathrm{II})$ complex to $\mathrm{Ni}(0)$ prior to the coupling reaction was not necessary to generate an active catalyst.

$$
\mathrm{NiCl}_{2}\left(\mathrm{PPh}_{3}\right)_{2} \stackrel{\text { (i) }}{\longrightarrow} \mathrm{Ni}\left(\mathrm{PPh}_{3}\right)_{\mathrm{n}}+\mathrm{Ar}-\mathrm{Ar}
$$

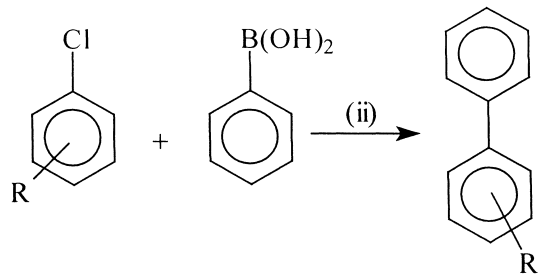

Scheme 24. (i) $2 \mathrm{ArB}(\mathrm{OH})_{2}, \mathrm{~K}_{3} \mathrm{PO}_{4} \cdot n \mathrm{H}_{2} \mathrm{O}$, toluene. (ii) $\mathrm{NiCl}_{2}\left(\mathrm{PPh}_{3}\right)_{2}$. $2 \mathrm{PPh}_{3}, \mathrm{~K}_{3} \mathrm{PO}_{4} \cdot n \mathrm{H}_{2} \mathrm{O}$, toluene, $80-100^{\circ} \mathrm{C}$.

Leadbeater and co-workers ${ }^{66}$ have developed two phosphine-free Ni complexes to carry out metal-mediated biaryl formation. These are air stable and the best results were obtained using the triethylamine-coordinated nickel complex 36 compared to the bipyridyl-coordinated adduct 37 . The catalyst has been used to couple a wide range of aryl halides with phenylboronic acid under optimised conditions (Scheme 25). The same group has shown that both Pd and Ni catalysts can be used for the SM coupling reaction of sterically hindered aryl bromides with phenylboronic acid. ${ }^{67}$<smiles>CCCCCCCN[N+](Cl)(Cl)CCC</smiles>

36

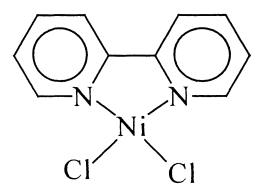

37

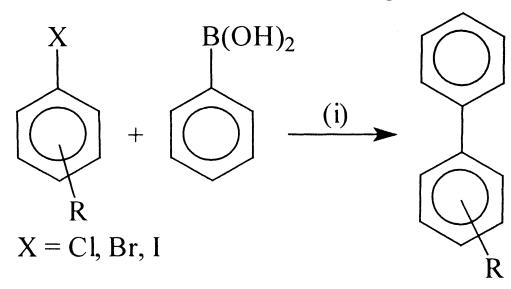

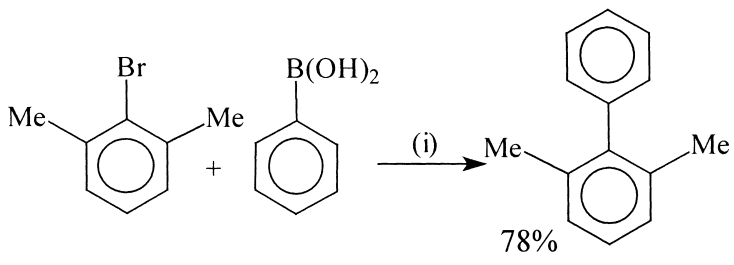

Scheme 26. (i) $\mathrm{Ni}\left[\mathrm{P}(\mathrm{OMe})_{3}\right]_{2} \mathrm{Cl}_{2}, \mathrm{P}(\mathrm{OMe})_{3}, \mathrm{~K}_{3} \mathrm{PO}_{4}$, dioxane, $95^{\circ} \mathrm{C}$.

The best results were obtained with trimethylphosphite as a ligand whereas $t-\mathrm{Bu}_{3} \mathrm{P}$ gave poor yields of the sterically crowded biaryls. This observation can be attributed to the difference in the cone angle between $t-\mathrm{Bu}_{3} \mathrm{P}\left(182^{\circ}\right)$ and $\mathrm{P}(\mathrm{OMe})_{3}\left(107^{\circ}\right)$ and therefore the distance to which the $\mathrm{Pd}$ complex can approach the aryl halides. The $\mathrm{P}(\mathrm{OMe})_{3} / \mathrm{Pd}$ complex is able to access and react with the sterically hindered aryl halides, whilst the $t-\mathrm{Bu}_{3} \mathrm{P}$ is unreactive. The same reaction was carried out with $\mathrm{Ni}$ catalysts such as $\mathrm{Ni}(\mathrm{dppf}) \mathrm{Cl}_{2}$ and $\mathrm{Ni}\left[\mathrm{P}(\mathrm{OMe})_{3}\right]_{2} \mathrm{Cl}_{2}$ and a higher catalyst efficiency has been observed compared to the $\operatorname{Pd}_{2}(\mathrm{dba})_{3} /$ $\mathrm{P}(\mathrm{OMe})_{3}$ catalyst mixture (Scheme 26).

Lipshutz $^{68}$ has reported biaryl coupling using a heterogeneous $\mathrm{Ni}$ catalyst $(\mathrm{Ni} / \mathrm{C})$ between functionalised aryl chlorides and arylboronic acids in good isolated yields (Scheme 27). After considerable experimentation, a useful set of reaction conditions $\left(\mathrm{Ni} / \mathrm{C}, 4 \mathrm{PPh}_{3}, \mathrm{~K}_{3} \mathrm{PO}_{4}, \mathrm{LiBr}\right.$, dioxane, reflux) has been developed which could be applied to a variety of substrates. Bidentate ligands (e.g. dppf, BINAP, dppe) appear to inhibit the extent of coupling. The magnitude of the homocoupling is often of the order of $10 \%$, which can be reduced to $5 \%$ by incorporating $\mathrm{LiBr}$ in the reaction mixture.

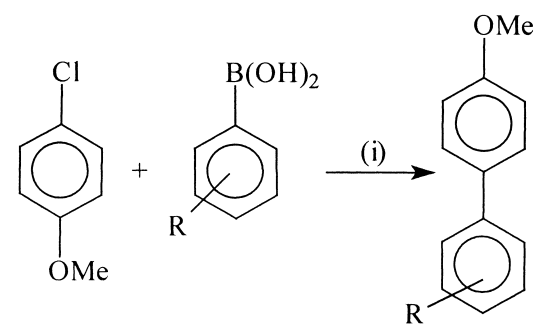

Scheme 27. (i) $\mathrm{Ni} / \mathrm{C}, \mathrm{PPh}_{3}, \mathrm{~K}_{3} \mathrm{PO}_{4}, \mathrm{LiBr}$, dioxane, reflux.

A limited number of reports are available on the application of arenesulphonates in the catalytic SM cross-coupling reaction. In one example, biaryl compounds were obtained in up to $81 \%$ yield using $\mathrm{NiCl}_{2}$ (dppf) and $\mathrm{Zn}$ in the $\mathrm{SM}$ cross-coupling of aryl mesylates with boronic acids. ${ }^{69}$ Higher yields were obtained using lithium arylborates. ${ }^{70}$ This reaction was, however, restricted to mesylates and tosylates containing EWGs. Recently, Monteiro and

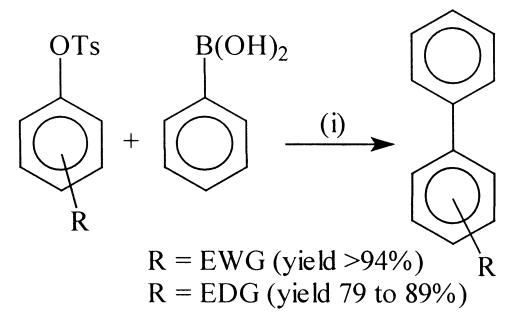

Scheme 28. (i) $\mathrm{NiCl}_{2}\left(\mathrm{PCy}_{3}\right)_{2}, \mathrm{PCy}_{3}, \mathrm{~K}_{3} \mathrm{PO}_{4}$, dioxane, $130^{\circ} \mathrm{C}$. 
co-workers ${ }^{71}$ have reported the use of the $\mathrm{NiCl}_{2}\left(\mathrm{PCy}_{3}\right)_{2}$ catalyst in the SM cross-coupling reaction of a variety of aryl tosylates with arylboronic acid under mild reaction conditions (Scheme 28).

\subsection{Two-phase SM cross-coupling reactions with water- soluble palladium complexes}

During the last few decades, homogeneous catalysis has made a significant impact on the development of organic synthesis. One of the major drawbacks of homogeneous catalysis is the expensive separation of the reaction product from the catalyst. The development of water-soluble catalysts that can be easily separated from the organicsoluble products at the end of the transformation therefore offers several advantages for the industrial production of fine chemicals. By utilising the most common water-soluble ligand $m$-trisulphonated triphenylphosphine (TPPTS) (Fig. 6) and $\mathrm{Pd}(\mathrm{OAc})_{2}$ in a $1: 4$ ratio an efficient active $\mathrm{Pd}(0)$ complex was generated in situ. ${ }^{72}$ More recently, a $\mathrm{Pd}(\mathrm{OAc})_{2}$ and guanidinium phenylphosphine combination has been used for the preparation of a water-soluble palladium(0) catalyst for the SM coupling reaction between iodoisophthalic acid and $p$-methoxyphenylboronic acid. ${ }^{73}$

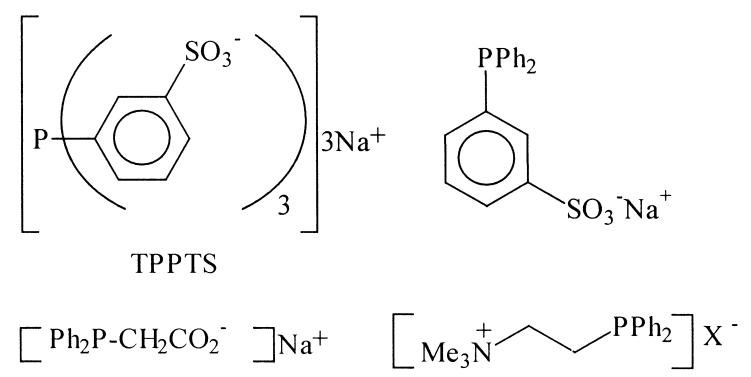

Figure 6. Partial list of water-soluble phosphines.

Paetzold and Oehme ${ }^{74}$ reported the coupling reaction of iodoanisole and phenylboronic acid in an aqueous medium $\left(78^{\circ} \mathrm{C}\right)$ in the presence of the $\mathrm{Pd}$ complex, $\mathrm{PdCl}_{2}\left[\mathrm{Ph}_{2}-\right.$ $\left.\mathrm{P}\left(\mathrm{CH}_{2}\right)_{4} \mathrm{SO}_{3} \mathrm{~K}\right]_{2}$, in toluene/ethanol/water with $\mathrm{Na}_{2} \mathrm{CO}_{3}$ as the base and surfactants as phase-transfer reagents (Scheme 29). With increasing concentrations of the surfactant, the rate of the reaction was increased and the formation of byproducts was suppressed. The catalytic system was active down to the ppm level, with a low self-coupling of the arylboronic acid.

Genêt and co-workers ${ }^{75}$ have described the SM crosscoupling of a wide range of arylboronic acids and esters with aryl and vinyl iodides at RT and they found that diisopropylamine was an effective base for this purpose.

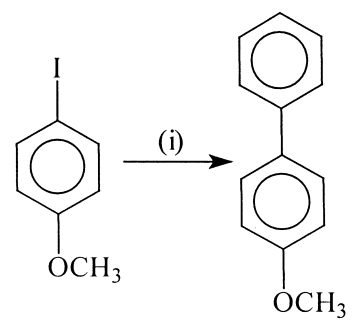

Scheme 29. (i) $\mathrm{PhB}(\mathrm{OH})_{2}, \mathrm{PdCl}_{2}\left[\mathrm{Ph}_{2} \mathrm{P}\left(\mathrm{CH}_{2}\right)_{4} \mathrm{SO}_{3} \mathrm{~K}\right]_{2}$, detergent, $\mathrm{Na}_{2} \mathrm{CO}_{3}$, toluene/ethanol $/ \mathrm{H}_{2} \mathrm{O}, 78^{\circ} \mathrm{C}$.

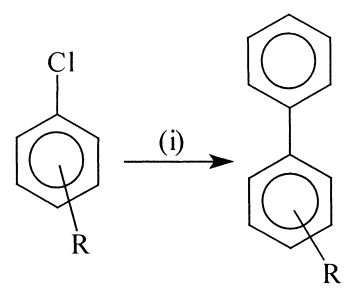

Scheme 30. (i) $\mathrm{PhB}(\mathrm{OH})_{2}, \mathrm{NiCl}_{2}$ (dppe), TPPTS, $\mathrm{Zn}, \mathrm{K}_{3} \mathrm{PO}_{4}$, dioxane/ $\mathrm{H}_{2} \mathrm{O}$ $(3: 1), 50^{\circ} \mathrm{C}$

The principle drawback of this protocol is the use of expensive aryl iodides as electrophiles. This methodology was subsequently extended to more desirable substrates such as aryl chlorides and bromides. In this regard, a watersoluble $\mathrm{Ni}(0)$ catalyst formed from $\mathrm{NiCl}_{2}$ (dppe) and TPPTS was found to catalyse the cross-coupling reaction of a variety of aryl chlorides with arylboronic acids to afford good yields of biaryls (Scheme 30). ${ }^{76}$ Additional studies indicated that the SM cross-coupling can be extended efficiently to a range of aryl bromides and arylboronic acids using a water-soluble $\operatorname{Pd}(0) / T P P T S$ catalyst under mild reaction conditions (Scheme 31$){ }^{77}$ This procedure has been extended to electron-rich and electron-poor substrates and provides an easy access to sterically hindered biaryls having three ortho-substituents with good ton. ${ }^{78}$ The catalyst can be recycled three times without loss of activity.

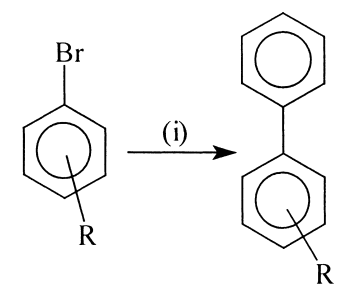

Scheme 31. (i) $\mathrm{PhB}(\mathrm{OH})_{2}, \mathrm{Pd}(\mathrm{OAc})_{2}$, TPPTS, $i-\mathrm{Pr}_{2} \mathrm{NH}, \mathrm{CH}_{3} \mathrm{CN} / \mathrm{H}_{2} \mathrm{O}(3: 1)$, $80^{\circ} \mathrm{C}$.

Although the water-soluble phosphines such as TPPTS have been applied to several other SM cross-coupling reactions with various aryl bromides, the activity of the catalytic system still remained too low to be industrially useful. ${ }^{78-80}$ Sterically demanding water-soluble phosphines $(\mathbf{3 8}, \mathbf{3 9}$ and 40 $)^{81}$ were, however, found to give highly active catalysts for the SM coupling of the aryl bromide in aqueous conditions at RT in excellent yields (Scheme 32). Coupling of the activated aryl chlorides required a high catalyst
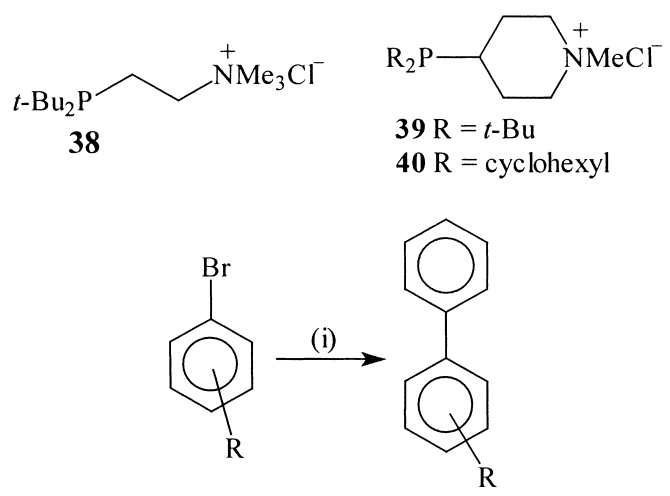

Scheme 32. (i) $\mathrm{ArB}(\mathrm{OH})_{2}, \mathrm{Pd}(\mathrm{OAc})_{2}$, phosphine, $\mathrm{Na}_{2} \mathrm{CO}_{3}, \mathrm{CH}_{3} \mathrm{CN} / \mathrm{H}_{2} \mathrm{O}$ (1:1), RT. 
loading and high temperature $\left(80^{\circ} \mathrm{C}\right)$. Tons of up to $734000 \mathrm{mmol} / \mathrm{mmol}$ of $\mathrm{Pd}$ have been achieved under mild reaction conditions.

\subsection{SM Cross-coupling reactions under phosphine-free Pd catalysts}

The SM cross-coupling reaction generally employs expensive Pd complexes as catalysts, which are difficult to prepare and recover. To overcome these problems, Kabalka and co-workers ${ }^{82}$ discovered that Pd powder and $\mathrm{KF}$ as a base were useful to couple aryl iodides with arylboronic acids in methanol (Scheme 33). These conditions can also be applied for the coupling of benzyl bromides with arylboronic acids but not with aliphatic boronic acids. Aryl bromides and chlorides were, however found to be ineffective partners. At the conclusion of the reaction, Pd metal can be recovered and recycled by simple decantation. In one instance, the catalyst was used eight times successively with no significant loss in the product yields.

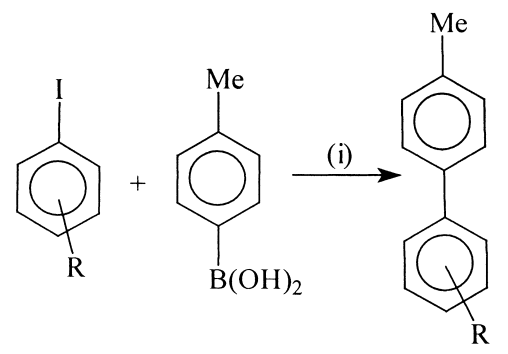

Scheme 33. (i) Pd, KF, 20\% aqueous $\mathrm{MeOH}$, reflux.

Commercially available $\mathrm{Pd}(\mathrm{OAc})_{2}$ or the sulphur-containing $\mathrm{Pd}$ complex, $\mathrm{PdCl}_{2}\left(\mathrm{SEt}_{2}\right)_{2}$, were two ligandless $\mathrm{Pd}$ systems used in the SM reaction of various aryl halides at RT (Scheme 34). ${ }^{83}$ The salt additive, $\mathrm{N}(n-\mathrm{Bu})_{4} \mathrm{Br}$, has a favourable effect on $\mathrm{Pd}(\mathrm{OAc})_{2}$ but no significant effect when using $\mathrm{PdCl}_{2}\left(\mathrm{SEt}_{2}\right)_{2}$. The role of the additive in this system was not clearly understood but it might have some effect on the stability of the anionic Pd species such as $[\mathrm{Br}-\mathrm{Pd} \text {-ligand }]^{-}$. These reaction conditions efficiently promote the RT coupling of the aryl bromides or the electron-poor aryl chlorides with phenylboronic acids leading to the biaryls in high yield $(>90 \%)$. With the electron-rich and electron-neutral aryl chlorides, the catalyst failed to react under these reaction conditions. It is noteworthy that aryl iodides and activated aryl bromides coupled with arylboronic acids at RT using $\mathrm{Pd}(\mathrm{OAc})_{2}$ in an aqueous medium. ${ }^{84,85}$

Ligandless heterogeneous $\mathrm{Pd}$ catalysts can activate the

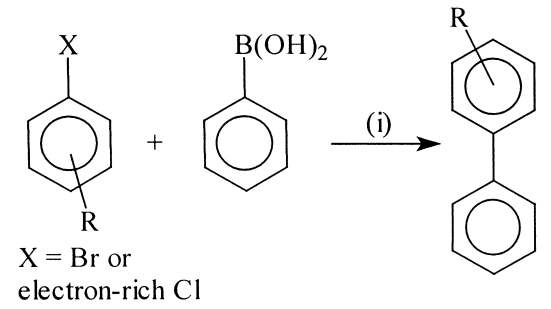

Scheme 34. (i) $\mathrm{Pd}(\mathrm{OAc})_{2}$ or $\mathrm{PdCl}_{2}\left(\mathrm{SEt}_{2}\right)_{2}, \mathrm{~K}_{3} \mathrm{PO}_{4},(n-\mathrm{Bu})_{4} \mathrm{~N}^{+} \mathrm{Br}^{-}, \mathrm{DMF}$, RT.

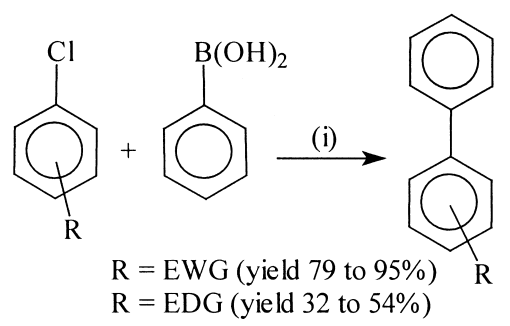

Scheme 35. (i) $\mathrm{Pd} / \mathrm{C}, \mathrm{K}_{2} \mathrm{CO}_{3}, \mathrm{DMA}-\mathrm{H}_{2} \mathrm{O}, 80^{\circ} \mathrm{C}$.

$\mathrm{C}-\mathrm{Cl}$ bond in aryl chlorides under the SM cross-coupling reaction conditions. ${ }^{86}$ More importantly, with a judicious choice of the solvent system (dimethylacetamide (DMA) and water $20 / 1$ at the optimum volumetric ratio), the homocoupling pathway of the aryl chlorides was blocked and the SM cross-coupling product was obtained selectively (Scheme 35). Aryl chlorides containing EWGs gave $79-95 \%$ yields of the cross-coupling products. Moderate yields have been obtained with neutral and electron-rich aryl chlorides, which were improved by using a larger amount of the catalyst. In homogeneous Pd chemistry, the choice of the ligand plays a critical role in the SM crosscoupling reaction of aryl chlorides. In contrast, the heterogeneous $\mathrm{Pd} / \mathrm{C}$ catalytic system can allow the SM cross-coupling reaction of aryl chlorides to occur under mild reaction conditions without the use of any added ligand, whilst the addition of phosphines such as $\mathrm{P}(t-\mathrm{Bu})_{3}$ or $\mathrm{PPh}_{3}$ brought the reaction to halt. The ability of a heterogeneous catalyst to activate the $\mathrm{C}-\mathrm{Cl}$ bond in aryl chlorides was explained in terms of a synergistic anchimeric and electronic effect that occurs between the Pd surface and the aryl chlorides.

A catalytic system containing supporting ligations other than expensive phosphines has recently been studied. Nolan and co-workers ${ }^{87}$ have developed a $\mathrm{Pd}(\mathrm{OAc})_{2}$ /diazabutadiene system which mediates the catalytic cross-coupling reaction of aryl halides with arylboronic acids (Scheme 36). A combination of the diazabutadiene ( $N, N^{\prime}$-dicyclohexyl1,4-diazabutadiene) and $\mathrm{Pd}(\mathrm{OAc})_{2}$ was found to be an efficient catalyst for the SM cross-coupling reaction of various aryl bromides or activated aryl chlorides with arylboronic acids.

\section{SM Cross-coupling reactions under green conditions}

The SM coupling reaction generally employs expensive organic solvents and complex Pd catalysts. These $\mathrm{Pd}$ reagents are difficult to recover and recycle. These problems have prompted several researchers to find green conditions to effect the SM cross-coupling reaction.

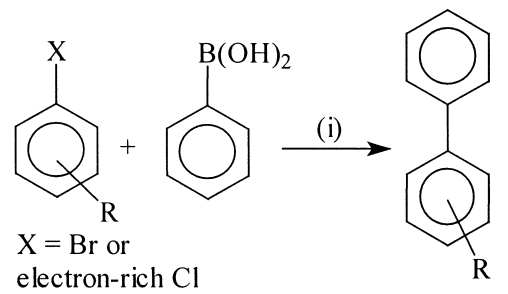

Scheme 36. (i) $\mathrm{Pd}(\mathrm{OAc})_{2}$, diazabutadiene, $\mathrm{Cs}_{2} \mathrm{CO}_{3}$, dioxane, $80^{\circ} \mathrm{C}$. 


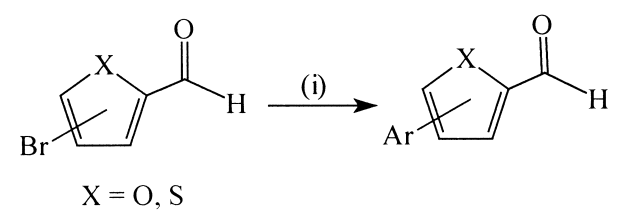

Scheme 37. (i) $\mathrm{ArB}(\mathrm{OH})_{2}, \mathrm{Pd}(\mathrm{OAc})_{2}, \mathrm{~K}_{2} \mathrm{CO}_{3}, \mathrm{Bu}_{4} \mathrm{~N}^{+} \mathrm{Br}^{-}, \mathrm{H}_{2} \mathrm{O}$, RT.

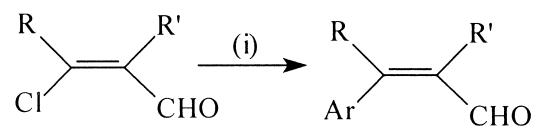

Scheme 38. (i) $\mathrm{ArB}(\mathrm{OH})_{2}, \mathrm{Pd}(\mathrm{OAc})_{2}, \mathrm{~K}_{2} \mathrm{CO}_{3}, \mathrm{Bu}_{4} \mathrm{~N}^{+} \mathrm{Br}^{-}, \mathrm{H}_{2} \mathrm{O}$.

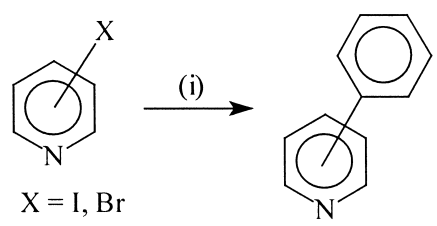

Scheme 39. (i) $\left(\mathrm{C}_{6} \mathrm{H}_{5}\right)_{4} \mathrm{BNa}, \mathrm{Pd}(\mathrm{OAc})_{2}, \mathrm{Na}_{2} \mathrm{CO}_{3}, \mathrm{H}_{2} \mathrm{O}$ or MMF, MW.<smiles>Cc1ccc(-c2cccc([O+])c2)cc1</smiles>

Scheme 40. (i) $\mathrm{Pd}(0), \mathrm{KF} / \mathrm{Al}_{2} \mathrm{O}_{3}, 100^{\circ} \mathrm{C}, 4 \mathrm{~h}$ or $\mathrm{MW}, 2$ min.
The feasibility of organic reactions in aqueous media is of heightened interest due to their obvious advantages. Bussolari and Rehborn ${ }^{88}$ found that in aqueous media the reaction between arylboronic acids and bromofurans (or bromothiophenes) occurred rapidly in the presence of $\mathrm{Pd}(\mathrm{OAc})_{2}$ (Scheme 37). Although the reaction mixture was non-homogeneous and aggregated, the overall yields of the reactions were good. The advantage of a ligandless Pd species-mediated SM cross-coupling reaction is the elimination of side reactions arising from phosphine ligands. This reaction was carried out in accordance with Badone's observation that tetrabutylammonium bromide accelerates the rate of the SM cross-coupling in water without the use of an organic solvent. ${ }^{89}$

Kirsch and Hesse ${ }^{90}$ have used the mild procedure to couple $\beta$-chloroacroleins with a wide variety of boronic acids to prepare tetrasubstituted alkenes (Scheme 38). Although aryl chlorides are less reactive due to their inert nature in the oxidative addition step, the SM cross-coupling of vinyl chloride is easier when compared to the aryl and alkyl chlorides.

Villemin and co-workers ${ }^{91}$ studied the possibility of the SM cross-coupling reaction (Scheme 39) of heteroaryl halides in monomethylformamide (MMF), which has a higher polarity than water and other amides under microwave irradiation conditions. The commercially available non-toxic sodium tetraphenylborate has been used in water (or MMF) for the phenylation of heteroaryl halides under mono-mode microwave irradiation

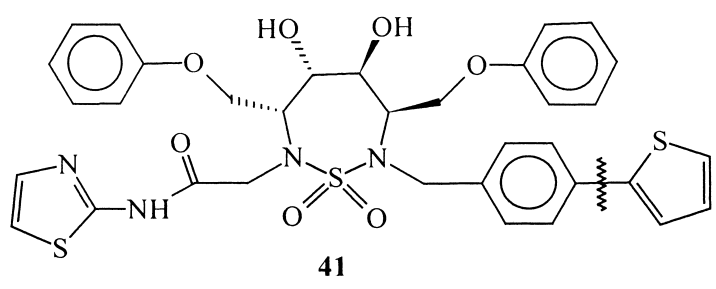

non-symmetric cyclic sulfonamide (HIV-1 protease inhibitor)<smiles>NC(=O)c1cc[14c]([125I])[14cH][14cH]1</smiles>

42<smiles>CC(C)(C)Cn1cnc2ccc(C(N)=O)cc21</smiles>

unsymmetrical substituted biaryl derivatives or $\mathrm{N}$-arylated heterocycles

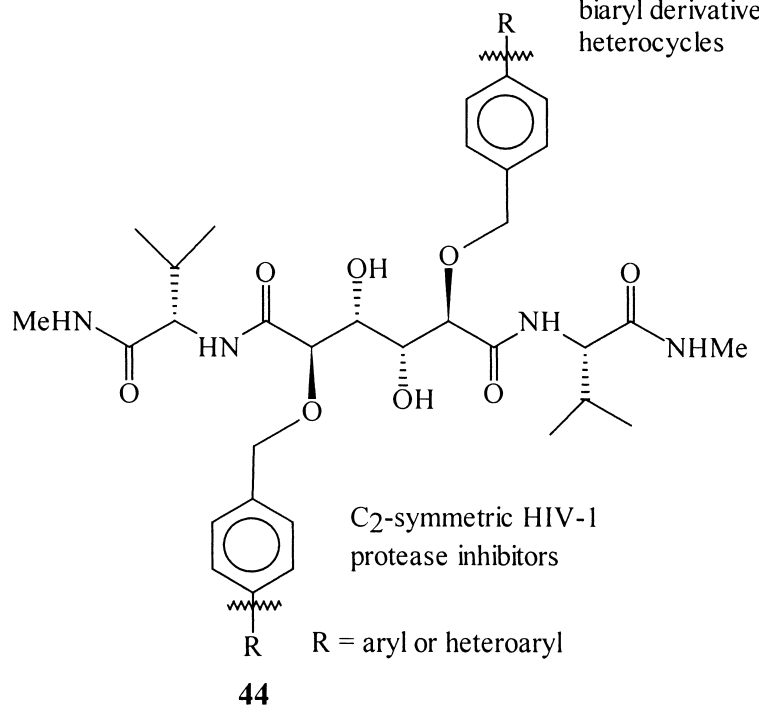

Figure 7. Some important drugs prepared by microwave-assisted SM cross-coupling reactions. 


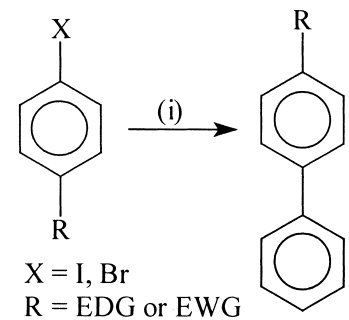

Scheme 41. (i) $\mathrm{PhB}(\mathrm{OH})_{2}, \mathrm{Pd}\left(\mathrm{PPh}_{3}\right)_{4},[$ bmim $]\left[\mathrm{BF}_{4}\right]$, aq. $\mathrm{Na}_{2} \mathrm{CO}_{3}, 110^{\circ} \mathrm{C}$, $10 \mathrm{~min}$.

conditions, accelerating the rate of reaction and affording the products more rapidly and cleanly.

Kabalka and co-workers ${ }^{92}$ used a commercially available $\mathrm{KF} / \gamma$-alumina mixture, doped with a ligandless $\operatorname{Pd}(0)$ catalyst (Scheme 40), to develop a novel, solventless SM cross-coupling methodology. They found that both $\mathrm{K}_{3} \mathrm{PO}_{4}$ and $\mathrm{KF}$ were effective bases for solid-phase coupling reactions at $100^{\circ} \mathrm{C}$. These solid-phase SM reactions were more successful for coupling arylboronic acids to aromatic halides but were unsuccessful for alkyl or vinyl halides. The solid-state methodology offers the opportunity to recycle the reagent by simple filtration. Later, they studied the effect of the microwave irradiation on the solid-phase reaction and found that the microwave irradiation leads to an enhanced yield of the desired product (Scheme 40). ${ }^{93}$ The straightforward recovery of the product and catalyst, conservation of energy through the use of microwave irradiation, and low waste protocols due to the absence of solvents make this method very attractive. In addition, the microwave-assisted reaction reduces the reaction time dramatically and has proved to be an efficient method in different areas of chemistry. ${ }^{94}$ A partial list of drug molecules 41-44 prepared by SM cross-coupling under solventless microwave conditions is shown in Fig. 7.95-98 The wavy line indicates the key $\mathrm{C}-\mathrm{C}$ or $\mathrm{C}$-heteroatom bond formed during the SM cross-coupling reaction.

Welton and co-workers ${ }^{99}$ reported Pd-catalysed SM crosscoupling reactions using ionic liquids such as 1-butyl-3methylimidazolium tetrafluoroborate $\left[(\mathrm{bmim})\left(\mathrm{BF}_{4}\right)\right]$ (Scheme 41). The new conditions involved heating the catalyst, $\mathrm{Pd}\left(\mathrm{PPh}_{3}\right)_{4}$, with the aryl halide in $[\mathrm{bmim}]\left[\mathrm{BF}_{4}\right]$ at $110^{\circ} \mathrm{C}$ with vigorous stirring until the formation of a complete solution, followed by the addition of arylboronic acid and base at RT. Peter and co-workers ${ }^{100}$ used a ballmilling procedure for the coupling of diverse aryl halides with phenylboronic acid under solvent-free conditions using $\mathrm{Pd}\left(\mathrm{PPh}_{3}\right)_{4}$ as a catalyst and $\mathrm{Na}_{2} \mathrm{CO}_{3}$ as a base.

Clark and co-workers ${ }^{101}$ reported a silica-supported phosphine-free Pd-catalysed SM reaction at low temperature using hydrocarbon solvents in the presence of small amount of the solid Pd catalyst which is entirely recoverable and reusable (Scheme 42). The most active and recyclable catalyst was prepared by the reaction of aminopropyl-TMS or aminopropylsilica with pyridinecarbaldehyde followed by complexation with $\mathrm{Pd}(\mathrm{OAc})_{2}$ (Scheme 42).

Varma and Naicker ${ }^{102}$ recently reported the synthesis of biaryl compounds (Scheme 43) using a new catalyst system, $\mathrm{PdCl}_{2}$ and tetraphenylphosphonium bromide-intercalated clay (Cat-I). These modified clay materials, unlike other conventional catalysts, enjoy considerable advantages such as ease of handling, recyclability, low cost and easy modulation of acidity levels by suitable exchange of cations. The same catalyst system has been used for the synthesis of allylbenzene under the same reaction conditions. ${ }^{103}$

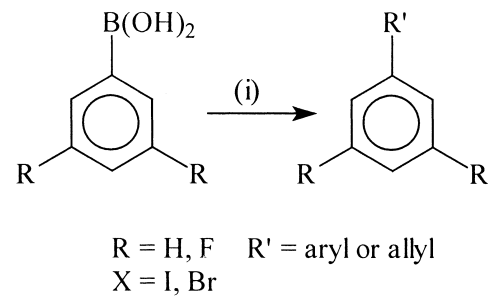

Scheme 43. (i) $\mathrm{R}^{\prime} \mathrm{X}$, Cat-I, DMF, $80^{\circ} \mathrm{C}$.

Colloidal metal particles are effective catalysts for chemical transformations due to their large surface area. Colloidal Pd on nanoscales is an effective catalyst for the SM crosscoupling reaction in organic solvents. The SM reaction was tested in the presence of catalytic amounts of $\left(\mathrm{C}_{8} \mathrm{H}_{17}\right)_{4} \mathrm{~N}^{+} \mathrm{Br}^{-}$-stabilised $\mathrm{Pd}$ clusters (size by TEM: $2-3 \mathrm{~nm})$ or $\left(\mathrm{C}_{4} \mathrm{H}_{9}\right)_{4} \mathrm{~N}^{+} \mathrm{Br}^{-}$-stabilised $\mathrm{Pd} / \mathrm{Ni}$ bimetallic clusters ( $3 \mathrm{~nm} ; \mathrm{Pd}: \mathrm{Ni}=1: 3)$ by Reetz and co-workers who

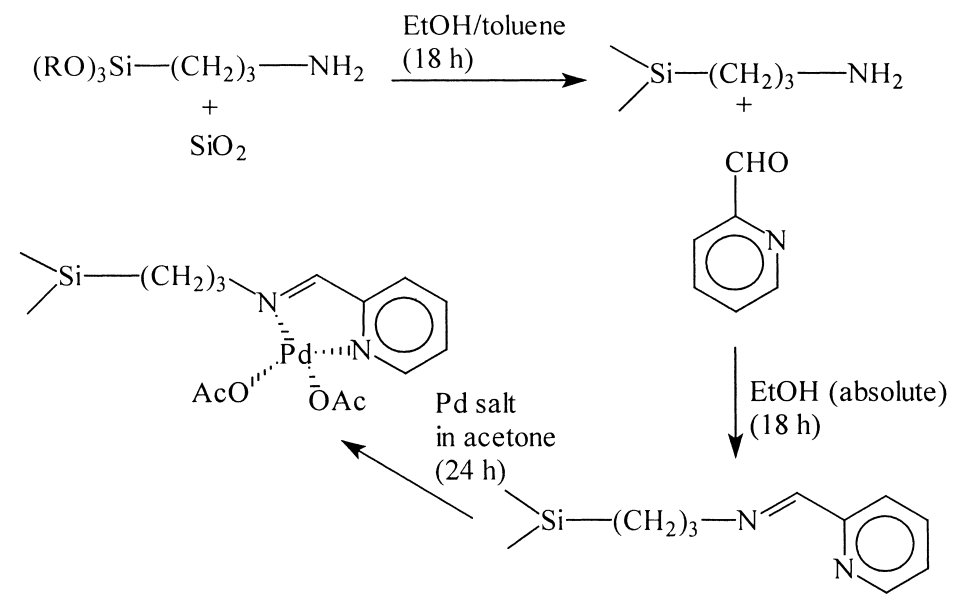

Scheme 42. 


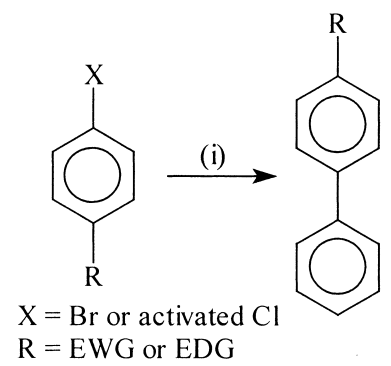

Scheme 44. (i) $\mathrm{PhB}(\mathrm{OH})_{2}$, Cat-II, base.

found that these are effective catalysts (Cat-II) in the reactions between phenylboronic acid and bromo- or activated chloroaromatics (Scheme 44). ${ }^{104}$ They also demonstrated that poly( $N$-vinyl-2-pyrrolidone) (PVP)-stabilised clusters are also active catalysts for the coupling reaction.

Sayed and co-workers ${ }^{105}$ have also reported the crosscoupling reaction using Pd nanoparticles stabilised by PVP in colloidal aqueous solution (Scheme 45). With the aid of fluorescence spectroscopy, they found that the initial rate of the reaction depends on the concentration of the Pd catalyst, providing strong evidence that the catalysis occurs on the surface of the Pd nanoparticles. Compared to the watersoluble Pd complexes, the colloidal solution is easily prepared and separated from the reaction products.

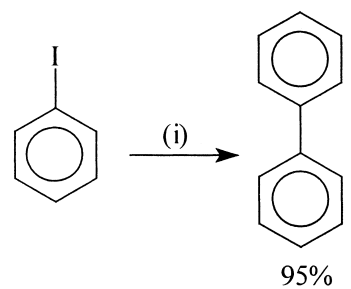

Scheme 45. (i) $\mathrm{PhB}(\mathrm{OH})_{2}$, PVP-Pd nanoparticle catalyst, $40 \% \mathrm{EtOH}$, reflux.

Schotten and co-workers ${ }^{106}$ recently reported the poly(ethyleneglycol) (PEG)-supported liquid-phase synthesis of biaryls by the SM cross-coupling reaction (Scheme 46). Compared to the non-polymer-supported liquid-phase reaction, a higher temperature is necessary to assure the quantitative conversion of the polymer-bound aryl halide into the SM coupling products, but the polymer-bound products were isolated in good yields by either simple precipitation of the soluble support or column filtration. The same group also studied the effect of microwave irradiation and found that this shortened the reaction time from $2 \mathrm{~h}$ to 2-4 min. The reaction proceeds well on PEG-bound aryl iodides, bromides, triflates and non-aflates in the presence of ligandless $\mathrm{Pd}(\mathrm{OAc})_{2}$ as the catalyst and without any organic co-solvent. They later used the same strategy to synthesise 1H-benzimidazoles, $1 \mathrm{H}$-imidazo[4,5-b]pyridines ${ }^{107}$ and 1H-imidazo[4,5-c] pyridines. $^{108}$

Varma $^{109}$ investigated the effect of various bases on the

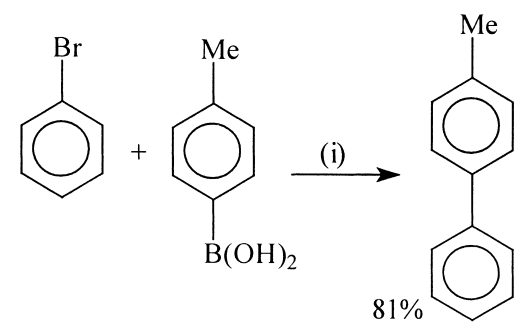

Scheme 47. (i) $\mathrm{PdCl}_{2}, \mathrm{KF}, \mathrm{PEG}-400, \mathrm{MW}, 50 \mathrm{~s}$.

PEG-based coupling reaction in the presence of microwave irradiation (Scheme 47) and found KF to be the most convenient protocol. The use of other bases requires water as the co-solvent for their dissolution, which not only reduces the solubility of the aromatic halides but also increases the self-coupling products of the boronic acids. PEG-400 and the relatively inexpensive $\mathrm{PdCl}_{2}$ have been used as a reaction medium and catalyst, respectively.

Hayashi and co-workers ${ }^{110}$ reported the coupling of aryl halides with arylboron reagents in aqueous media using an amphiphilic poly(ethyleneglycol)-polystyrene (PEG-PS) resin-supported triarylphosphine-Pd complex as the catalyst (Cat-III) (Scheme 48).

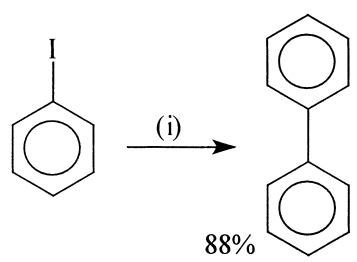

Scheme 48. (i) $\mathrm{PhB}(\mathrm{OH})_{2}$, Cat-III, aq. $\mathrm{KOH}$, RT.

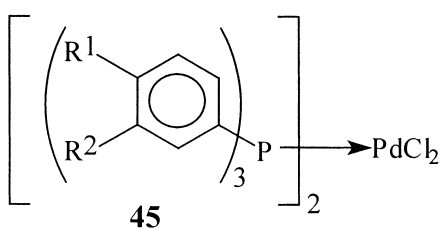

(a) $\mathrm{R}^{1}=\mathrm{C}_{8} \mathrm{~F}_{17}, \mathrm{R}^{2}=\mathrm{H}$

(b) $\mathrm{R}^{1}=\mathrm{H}, \mathrm{R}^{2}=\mathrm{C}_{8} \mathrm{~F}_{17}$

(c) $\mathrm{R}^{1}=\mathrm{C}_{8} \mathrm{~F}_{17} \mathrm{C}_{2} \mathrm{H}_{4}, \mathrm{R}^{2}=\mathrm{H}$

(d) $\mathrm{R}^{\mathrm{l}}=\mathrm{H}, \mathrm{R}^{2}=\mathrm{C}_{8} \mathrm{~F}_{17} \mathrm{C}_{2} \mathrm{H}_{4}$<smiles>[R]c1ccc(-c2ccccc2)cc1[R]</smiles>

Scheme 49. (i) $\mathrm{PhB}(\mathrm{OH})_{2}, 45, \mathrm{Na}_{2} \mathrm{CO}_{3}, \mathrm{CF}_{3} \mathrm{C}_{6} \mathrm{H}_{11}, \mathrm{DME}, 75^{\circ} \mathrm{C}$.

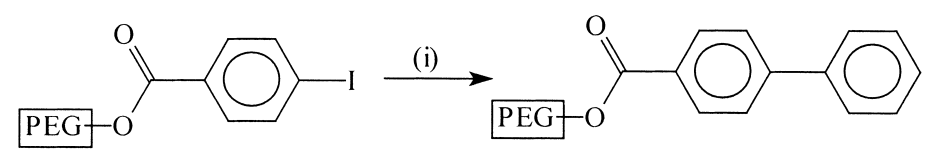

Scheme 46. (i) $\mathrm{PhB}(\mathrm{OH})_{2}, \mathrm{Pd}(0), \mathrm{H}_{2} \mathrm{O}$. 


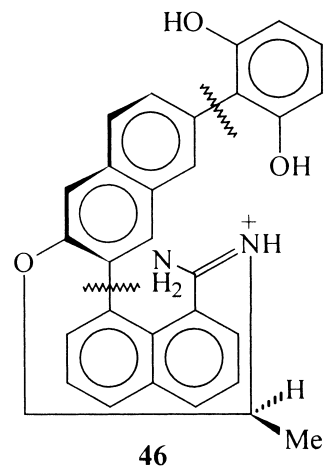<smiles>O=C([O-])c1cccc(C(=O)[O-])c1-c1cccc2ccccc12</smiles>

47<smiles>C[C@H](Cc1ccccc1N)c1ccccc1CC#N</smiles>

48<smiles>COc1ccccc1C(C)c1cc(C(C)=O)ccc1OC</smiles>

49<smiles>CC(=O)c1cccc(C(C)(C)c2cccc([N+](=O)[O-])c2)c1</smiles><smiles>CC(C)(c1ccccc1)c1ccc(C(O)C(=O)O)cc1</smiles><smiles>COc1ccccc1C(C)(C)c1ccccc1-c1ccccc1</smiles>

51<smiles>COc1ccc(C(C)(C)c2cc(Br)cc(C=O)c2O)cc1</smiles><smiles>CC(C)(C)c1ccc(Cl)cc1Cl</smiles><smiles>Cc1cc([14CH3])c(O)c(Cl)c1</smiles><smiles>COc1ccccc1CCc1cccc(C#N)c1C#N</smiles>

57

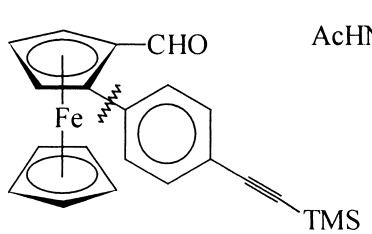

58

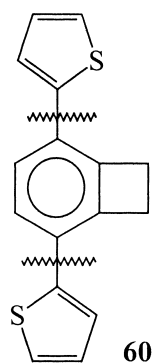

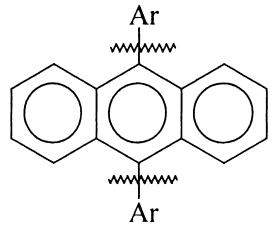

61

Figure 8. Different types of heterobiaryls synthesised via SM cross-coupling reactions.

Schneider and Bannwarth ${ }^{111}$ have performed the SM crosscoupling reaction (Scheme 49) with a perfluoro-tagged $\mathrm{Pd}$ catalyst $\mathbf{4 5}$ under a fluorous biphase system with either electron-rich or electron-deficient aryl bromides and arylboronic acids. The catalyst was recycled six times after phase separation without significant decrease in the coupling yields. At $75^{\circ} \mathrm{C}$, the reaction mixture was homogeneous but at room temperature the phase separation takes place.

\section{Synthesis of biphenyls and related systems}

The application of SM cross-coupling reactions is increasing rapidly for assembling diverse molecular frames and various functionalised biaryl and hetero-biaryl systems have been synthesised in the last few years. Due to space limitations, it is not possible to discuss all these novel methods in detail and we have therefore included some selected biaryl systems prepared by the SM cross-coupling reaction as a key step. The wavy line indicates the newlyformed $\mathrm{C}-\mathrm{C}$ bond between two aryl or aryl-heteroaryl systems as shown in Fig. 8.

\subsection{Biaryls and hetero-biaryls}

The axially chiral amidenium ion $\mathbf{4 6}$ and its congener were synthesised in connection with molecular recognition and hydrogen bonding studies with guest molecules. ${ }^{112}$ The introduction of aryl groups into a $\mathrm{Cr}$ [arene] complex by the SM cross-coupling reaction resulted in the sterically hindered chiral monodentate phosphines of the type 47 which are useful ligands in asymmetric catalysis. ${ }^{113}$ The sterically hindered biaryl systems $\mathbf{4 8}$ are important 


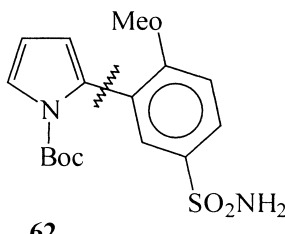

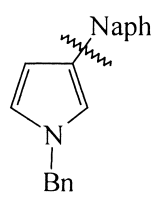

63

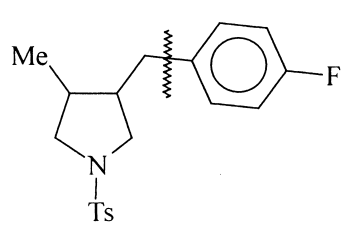<smiles>COc1ccc(C2=N[C@](C)(c3ccc(F)cc3)C(c3ccncc3)=C2c2ccc(OC)c(C)c2)cc1</smiles><smiles>COc1ccccc1-c1cccnc1C(C)(C)C</smiles>

67<smiles>[Y4]C1OCc2cc(C(C)(C)C)ccc2O1</smiles>

68<smiles>Cc1ccc(-c2ccc(C(=O)O)cc2)nc1</smiles><smiles>Cc1ccc2ccccc2c1</smiles>

70<smiles>Cc1ccc(CC(C)C)nn1</smiles><smiles>COc1ccc(-c2cc(-c3ccc(C#N)cc3)nn2-c2ccccc2)cc1</smiles><smiles>CCOc1noc(C)c1[C@H](C)c1ccncc1</smiles>

74<smiles>Cc1c(C)n(C)c2ncccc12</smiles>

75

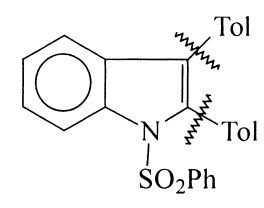

76

Figure 8 (continued)

structural elements in several natural products such as (-)rhazinilam ${ }^{114}$ and were synthesised from the SM crosscoupling of haloamines and boronic acids using sterically hindered phosphine ligands. ${ }^{25}$ The reaction of sterically hindered arylboronates with 3-iodo-4-methoxymethyl benzoates gave the aryl-substituted methyl benzoates 49 in moderate to good yields. ${ }^{115}$ Hamilton et al. synthesised the functionalised terphenyl system 50, which acts as an inhibitor of protein farnesyltransferase, by using the SM cross-coupling reaction of the appropriate starting materials. ${ }^{116}$

Tiffin and co-workers synthesised the aryl-substituted mandelic acid derivatives $\mathbf{5 1}$ by SM cross-coupling under $\mathrm{Pd} / \mathrm{C}$ catalytic conditions. ${ }^{117}$ The SM cross-coupling reaction of bromo-triphenylphosphine oxides with the corresponding arylboronic acids gave the aryl-substituted triphenylphosphine oxides which on further reduction with trichlorosilane gave the biphenylphosphine ligands $\mathbf{5 2}$ in good yields. ${ }^{118}$ Terphenyl units containing ferrocene, e.g. $\mathbf{5 3}$, were synthesised with the aim of studying their nonlinear optical properties. ${ }^{19}$ A variety of aryl-substituted salicylaldehydes 54 were obtained from the SM crosscoupling reaction of bromosalicylaldehydes and the corresponding arylboronic acids in moderate to good yields. ${ }^{120}$ Polychlorinated biphenyls $\mathbf{5 5}$ and hydroxy-polychlorinateds biphenyls 56 were synthesised by the SM cross-coupling reaction and their derivatives are useful in environmental studies. ${ }^{21,122}$

Phthalonitriles of the type $\mathbf{5 7}$ were synthesised via the SM cross-coupling of aryl halides and triflates with the 


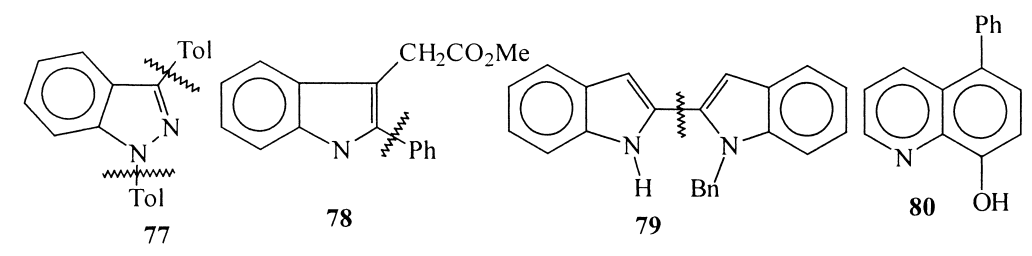

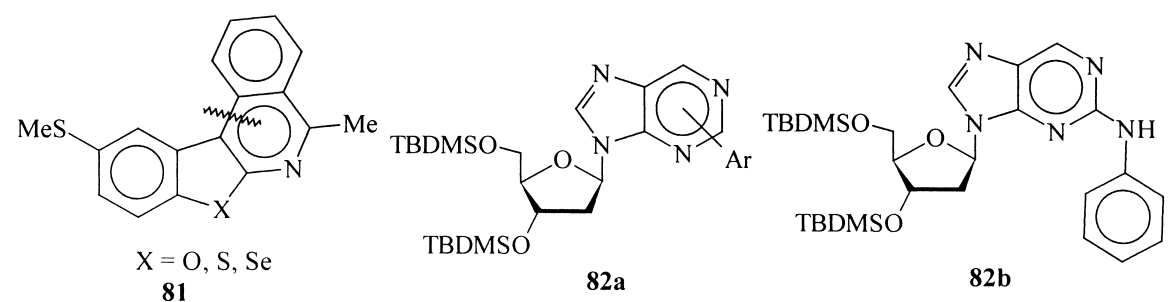

81<smiles>CCCn1cnc2c(Nc3ccc(OC)cc3)nc(C)nc21</smiles>

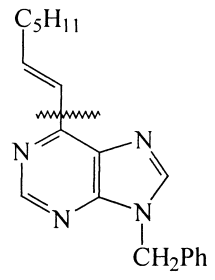

84<smiles>Cn1c(-c2ccccc2)nc2c(N)ncnc21</smiles>

85

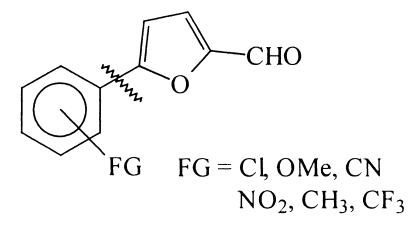<smiles>O=Cc1ccc(-c2cccc([N+](=O)[O-])c2)o1</smiles>

86

Figure 8 (continued)

corresponding arylboronic acids and incorporated into the periphery of phthalocyanines. ${ }^{123}$ Riant and Mamane synthesised aryl-substituted chiral ferrocene aldehydes such as 58, which are useful precursors of azomethyne ylides for [3+2] cycloadditions with $\mathrm{C}_{60}$ fullerenes. ${ }^{124} \mathrm{In}$ connection with the design of molecular electronic devices, the biaryl system 59 was synthesised from the SM crosscoupling of 2,5-dibromo-4-nitro-acetanilide. ${ }^{125}$ Recently, Kotha et al. have synthesised various benzocyclobutene building blocks such as 60 based on the SM cross-coupling reaction, ${ }^{126}$ and used the same methodology for the preparation of 9,10-diarylanthracene derivatives, e.g. $61 .^{127}$

Aryl 2,5-disubstituted pyrroles show selective dopamine $\mathrm{D}_{3}$ receptor antagonist properties and 3-substituted pyrroles are present in several natural products. In this connection, the Johnson and the Lee groups have reported the synthesis of the 2- and 3-substituted pyrroles 62 and 63 via a $\mathrm{Pd}\left(\mathrm{PPh}_{3}\right)_{4}-$ catalysed SM cross-coupling reaction. ${ }^{128,129}$ Compound $\mathbf{6 2}$ can be further used for synthesising 2,5-disubstituted pyrroles. The $\mathrm{Pd}\left(\mathrm{PPh}_{3}\right)_{4}$-catalysed cascade cyclisationcoupling reaction furnished the 3-arylmethylpyrrolidines 64 via a $\beta$-hydride elimination process. ${ }^{130}$ Revesz et al. have synthesised the 4,5-disubstituted imidazole $\mathbf{6 5}$, a potent anti-inflammatory drug, using the SM cross-coupling reaction as a key step. ${ }^{131}$
Aryl-substituted pyridines are an important class of compounds in medicinal chemistry and materials science. In this regard, Finney and co-workers prepared the 2,4,6trisubstituted pyridines $\mathbf{6 6}$ by using a stepwise SM crosscoupling reaction of the corresponding trihalopyridine and the arylboronic acids. ${ }^{132}$ These pyridine derivatives show fluorescent chemosensor properties. Similarly, Gallagher reported the synthesis of the 2,3-disubstituted pyridine $\mathbf{6 7}$ from 2-bromopyridine. ${ }^{133}$ The $\mathrm{PdCl}_{2}(\mathrm{dppf})$ - and $\mathrm{Pd}\left(\mathrm{PPh}_{3}\right)_{4}$ catalysed reactions of 4-pyridylboronic acid with the corresponding bromides gave $\mathbf{6 8}$, which can furnish pyridine-substituted salicylaldehydes on further functional group transformations. ${ }^{134}$ The reaction of carboxybenzeneboronic acid with heteroaryl bromides and chlorides gave the heteroaryl benzoic acids 69 in moderate to good yields. ${ }^{135}$

Jones et al. have developed a simple and general method for the synthesis of the substituted pyrazine systems $\mathbf{7 0}$ based on the SM cross-coupling reaction of 2-amino-3-benzoyl-5bromopyrazine with arylboronic acids (it is interesting to note that the pyrazine unit is present in a luminescent chromophore, coelenterazine, and other marine natural products). ${ }^{136}$ Gmeiner synthesised the 7-substituted pyrazolo[1,5- $a$ ]pyridines $\mathbf{7 1}$ by an SM cross-coupling protocol in connection with the replacement of these compounds as 
bioisosteres of indole-related drugs. ${ }^{137}$ The $\mathrm{Pd}\left(\mathrm{PPh}_{3}\right)_{4}$ catalysed reaction of 1-aryl-5-bromopyrazoles and pyridazine triflates with the corresponding boronic acids gave the 3,5-disubstituted-1-arylpyrazoles $\mathbf{7 2}$ and the heteroarylpyridazines 73, respectively. ${ }^{138,139}$ Larsen and co-workers synthesised the aryl-substituted isoxazole derivatives $\mathbf{7 4}$, that possess a structural similarity with ionotropic glutamic acid receptors. ${ }^{140}$

Aryl-substituted indoles and azaindoles are used as antipsychotic and anti-inflammatory drugs and, in this connection, Yum and co-workers have reported the synthesis of 2-aryl derivatives of 5- and 7-azaindoles $\mathbf{7 5}$ by a $\mathrm{Pd}(\mathrm{OAc})_{2}$-catalysed reaction of $\mathrm{N}$-protected 2-iodo-3methylazaindoles with arylboronic acids in good yields. ${ }^{141}$ Along similar lines, Gribble and co-workers have reported the synthesis of the 2,3-substituted diarylindoles $\mathbf{7 6}$ from the dihaloindoles and boronic acids. ${ }^{142}$ Rault et al. demonstrated a one-pot synthesis of the 1,3-diarylindazoles 77 via $\mathrm{Pd}(\mathrm{OAc})_{2}$-catalysed $C$-arylation and $\mathrm{Cu}(\mathrm{OAc})_{2}$-catalysed $\mathrm{N}$-arylation from 3-iodoindazole and the corresponding boronic acids. ${ }^{143}$ The 2,3-disubstituted indole 78 was synthesised using a radical cyclisation followed by the SM cross-coupling reaction. ${ }^{144}$ The $\mathrm{Pd}\left(\mathrm{PPh}_{3}\right)_{4}$-catalysed reaction of 2-iodoindole with $N$-protected 2-iodoindoles furnished the unsymmetrical 2,2'-bi-indolyls 79 in good yields. ${ }^{145}$

Wendeborn and co-workers reported the 5-arylquinoline-8-ol 80 from the 5-haloquinoline-8-ol. ${ }^{146}$ Kirsch et al. synthesised benzo-annelated isoquinoline derivatives such as $\mathbf{8 1}$ by using the SM cross-coupling reaction as a key step. ${ }^{147}$

Purines are very important components of biological systems. They act as several protein receptors and enzyme inhibitors. Lakshman and co-workers have synthesised the hydrophobic C-6 and C-2 aryl-2'-deoxynucleosides 82a ${ }^{148 a}$ and $\mathbf{8 2} \mathbf{b}^{148 b}$ via a Pd-catalysed reaction of the corresponding halopurines with arylboronic acids and arylamines, to study the reactivity at the C-2 and C-6 positions of deoxynucleosides as well as to compare the $\mathrm{C}-\mathrm{C}$ versus $\mathrm{C}-\mathrm{N}$ bondformation reactions. Similarly, Gray and Schultz reported the synthesis of a variety of functionalised purine libraries 83 based on the SM cross-coupling of chloropurines and boronic acids by using $\operatorname{Pd}_{2}(\mathrm{dba})_{3}$ as the catalyst in the presence of $\mathrm{N}$-heterocyclic carbene complexes as ligands. They also functionalised the $\mathrm{N}$-atom of purine at the 9-position by using $\mathrm{Cu}(\mathrm{OAc})_{2}$ and boronic acids. ${ }^{149}$ Similarly, Dvoŕák and Hocek have prepared the 2-, 6-, and 8-aryl- and alkenylpurines 84 and 85 from the corresponding halopurines in good yields. ${ }^{150}$

Aryl-substituted furan systems are important structural units in several natural products and the substituted furan derivatives sometimes show biological activity. Furan compounds are also used as food additives. In this regard, McClure et al. have developed a simple method for the arylsubstituted furaldehydes $\mathbf{8 6}$ by a $\mathrm{PdCl}_{2}$-catalysed reaction of aryl halides and 2-furaldehyde-boronic acid. ${ }^{151}$ In the same way, they reported an efficient one-pot synthesis of the 5-aryl-2-furaldehydes 87 by in situ generation of 5-(diethoxymethyl)-2-furylboronic acid followed by SM cross-coupling with aryl iodides and bromides under $\mathrm{Pd} / \mathrm{C}$ catalytic conditions. ${ }^{152}$

\subsection{Biphenylene systems}

Biphenylene (paraphenyl) systems and their homologues such as terphenyl and polyphenyl systems are important structural elements in most of the liquid crystals, fluorescent compounds, conducting polymers, dendrimers, etc. Heteroaryls like bipyridyls, phenanthrolenes and their derivatives act as chelating ligands and these are useful in coordination chemistry and in asymmetric catalysis. Fuelled by the above

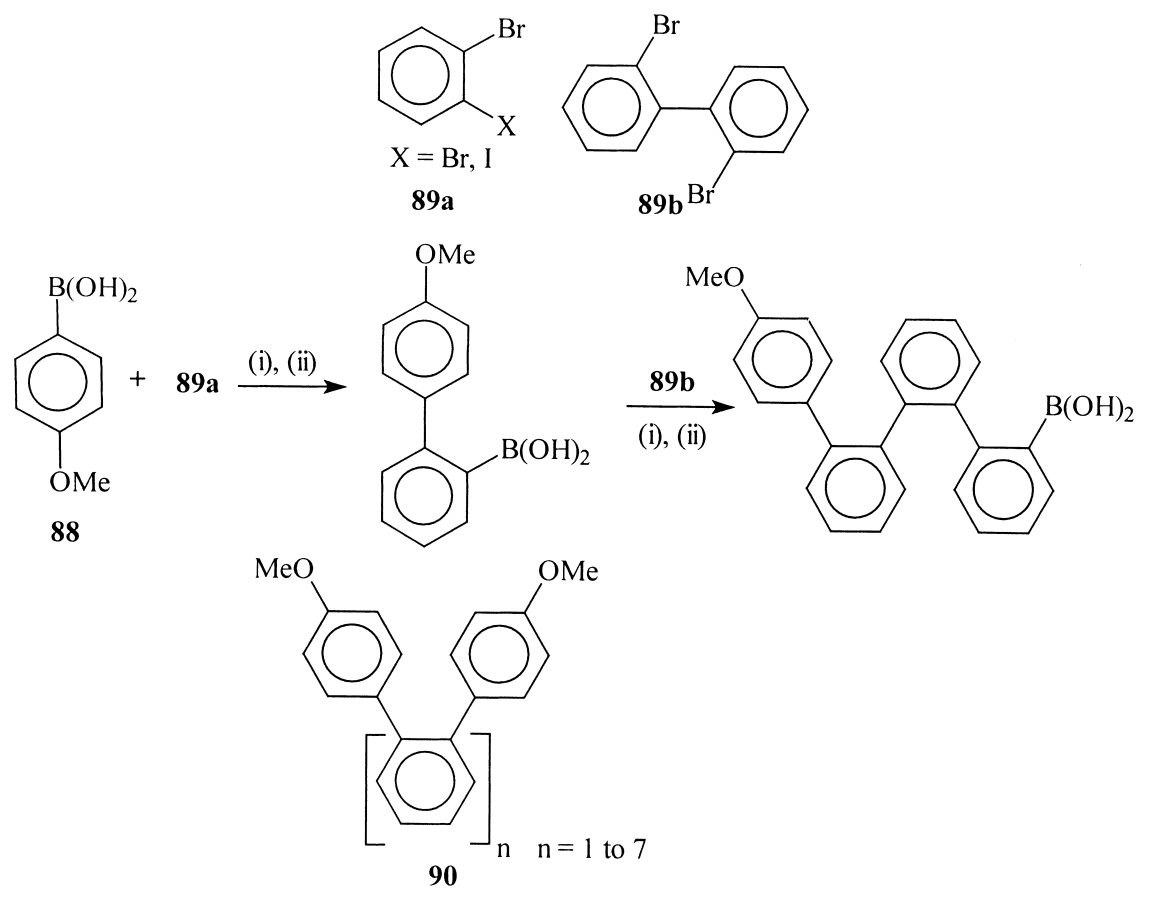

Scheme 50. (i) $\mathrm{Pd}\left(\mathrm{PPh}_{3}\right)_{4}$ or $\mathrm{PdCl}_{2}\left(\mathrm{PPh}_{3}\right)_{2}, \mathrm{Ba}(\mathrm{OH})_{2}, \mathrm{DME}, \mathrm{H}_{2} \mathrm{O}$, reflux. (ii) $n$-BuLi, THF, $-78^{\circ} \mathrm{C}, \mathrm{B}\left(\mathrm{OPr}^{i}\right)_{3}$ 


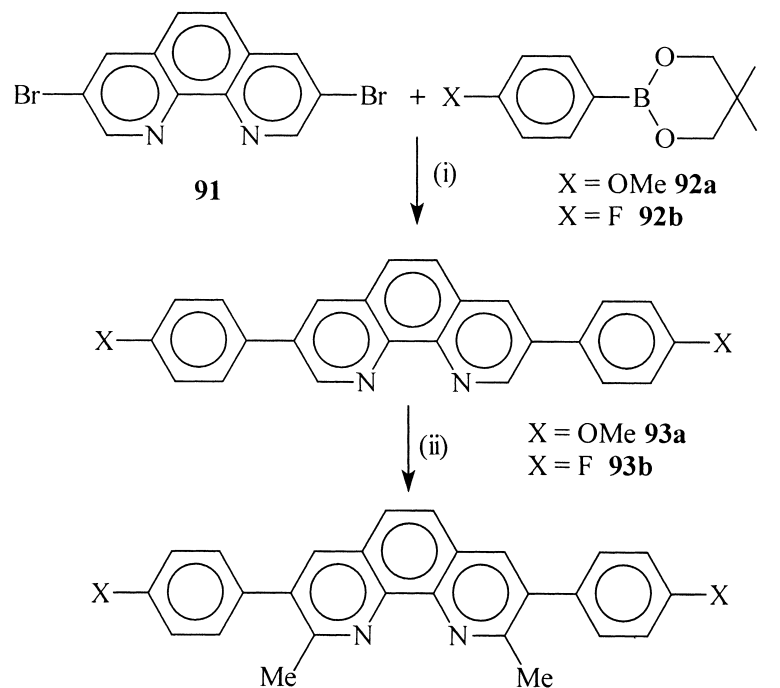

Scheme 51. (i) $\mathrm{Pd}\left(\mathrm{PPh}_{3}\right)_{4}(10 \%), \mathrm{Na}_{2} \mathrm{CO}_{3}$, toluene, $80^{\circ} \mathrm{C}, 12 \mathrm{~h}, \mathbf{9 2 a}: 82 \%$, 92b: $78 \%$. (ii) $\mathrm{MeLi}$, toluene, $0-5^{\circ} \mathrm{C}, 4 \mathrm{~h}, \mathrm{H}_{2} \mathrm{O}, \mathrm{MnO}_{2}$.

reasons, the development of simpler methods for the synthesis of these biphenylenes is still finding priority in the literature. In this connection, the SM cross-coupling reaction has become a useful tool for assembling these systems.

Simpkins and co-workers synthesised the helical orthophenylene oligomers 90 by using sequential SM crosscoupling reactions starting with $p$-methoxyphenylboronic acid $\mathbf{8 8}$ and the dihaloarenes $\mathbf{8 9 a}$ or $2,2^{\prime}$-dibromobiphenyl $\mathbf{8 9 b}$ as shown in Scheme 50. ${ }^{153}$

The $\mathrm{Pd}\left(\mathrm{PPh}_{3}\right)_{4}$-catalysed $\mathrm{SM}$ cross-coupling reaction of 3,8-dibromo-1,10-phenanthrolene 91 with the arylboronic acids 92a and 92b gave the coupling products 93a and 93b and their subsequent methylation yielded the tetrasubstituted 1,10-phenanthrolines, useful building blocks for materials science (Scheme 51). ${ }^{154}$

Buchecker et al. reported a simple strategy involving the SM and the Stille cross-coupling reactions for synthesising a dissymmetric ligand 94 containing 1,10-phenanthroline and $2,2^{\prime}, 6^{\prime}, 2^{\prime \prime}$-terpyridine units as two different chelates connected by a 1,3-phenylene spacer (Fig. 9). ${ }^{155}$

Anderson and co-workers synthesised a terphenyl system of the type 97 to prepare semiconductive, luminescent conjugated polyrotaxanes by using the $\mathrm{Pd}(\mathrm{OAc})_{2}$-catalysed SM cross-coupling reaction between the 4,4'-biphenyldiboronic ester 95 and 4,4'-diiodobiphenyl-2,2 $2^{\prime}$-dicarboxylic acid 96 as indicated in Scheme $52 .{ }^{156}$

Diarylnaphthalenes such as $\mathbf{1 0 0}$ resulted from the $\mathrm{Pd}\left(\mathrm{PPh}_{3}\right)_{4}$-catalysed double SM cross-coupling reaction of naphthalene 1,4-diboronic acid 98 with the aryl bromide 99 (Scheme 53) and have been used as key intermediates for the preparation of the carcinogenic polycyclic aromatic compound 101 and its metabolites. ${ }^{157}$

In connection with studies related to metal detector selfassembly processes, rod-like rigid linear di- and tri-catechol

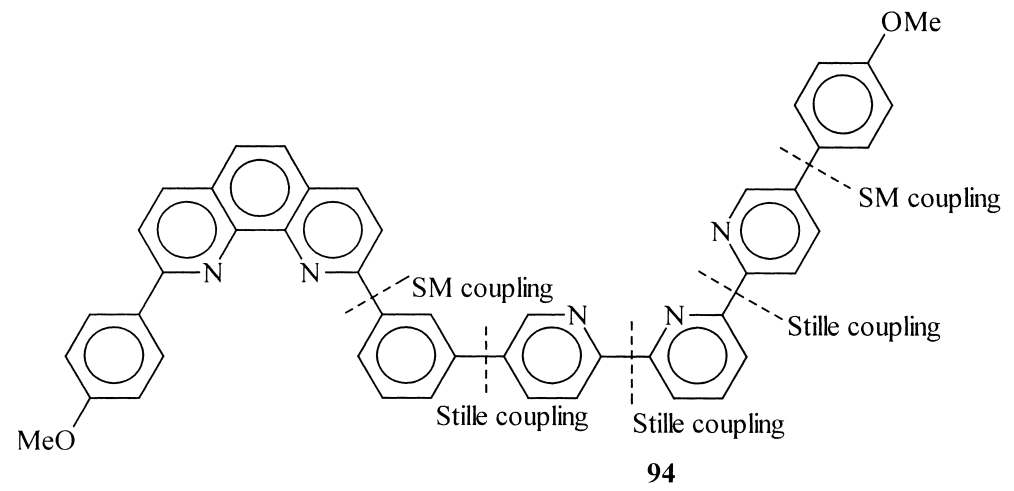

Figure 9. 1,10-Phenanthroline based ligand.

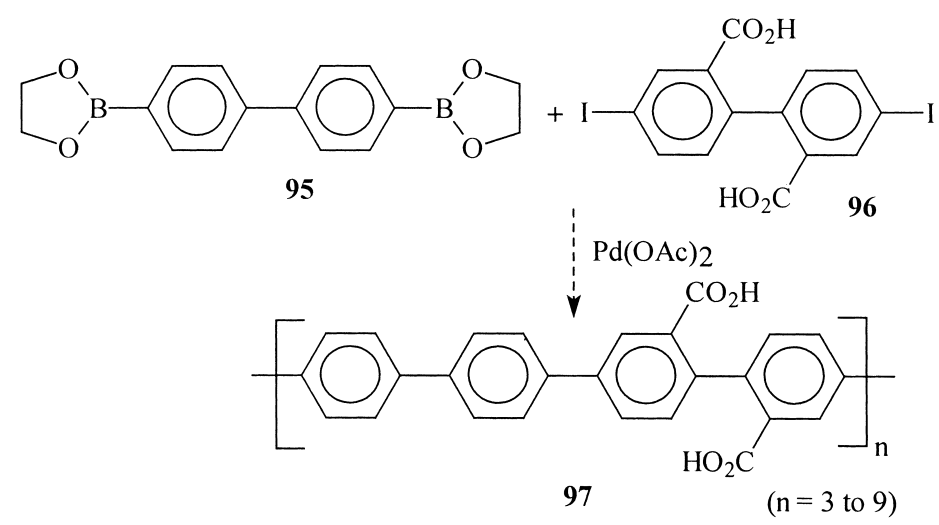

Scheme 52. 


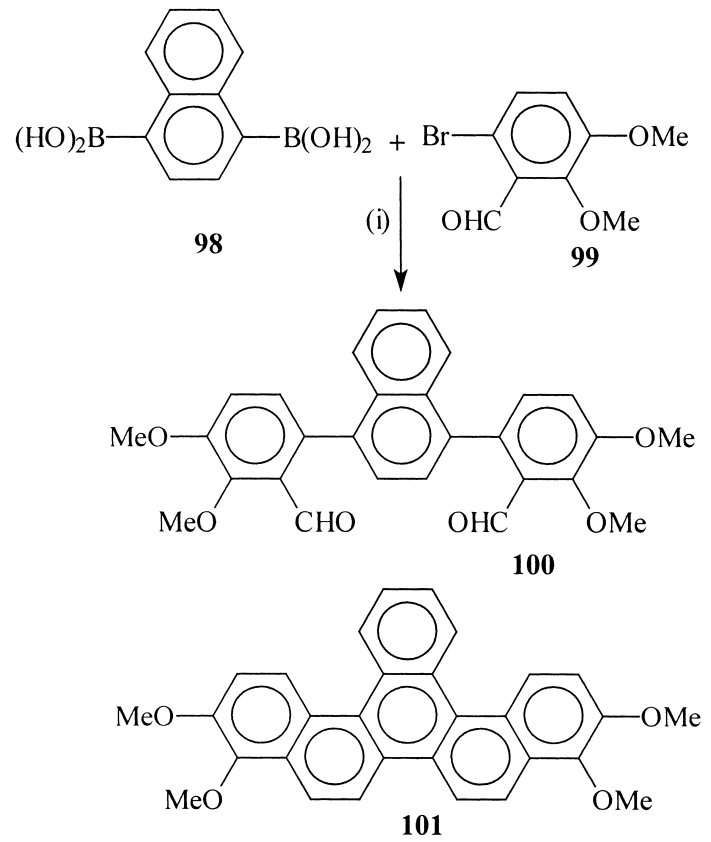

Scheme 53. (i) $\mathrm{Pd}\left(\mathrm{PPh}_{3}\right)_{4}, \mathrm{Na}_{2} \mathrm{CO}_{3}$, DME, reflux, 20 h, $90 \%$.

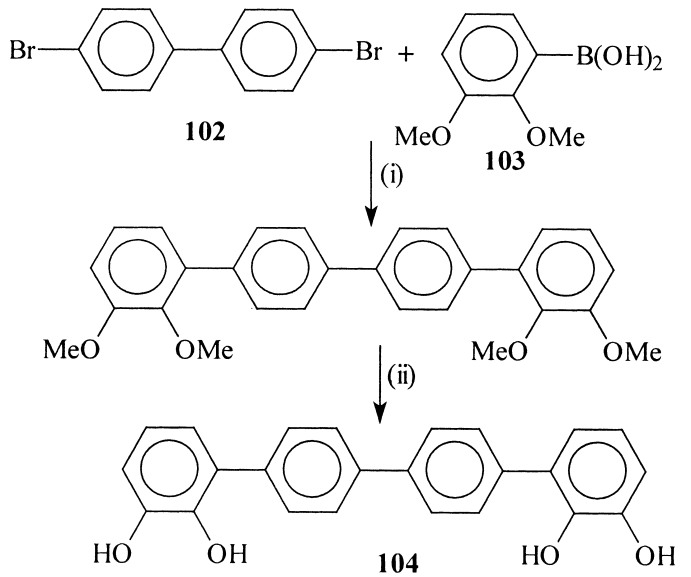

Scheme 54. (i) $\mathrm{Pd}\left(\mathrm{PPh}_{3}\right)_{4}, \mathrm{Na}_{2} \mathrm{CO}_{3}$, toluene, $\mathrm{EtOH}$, reflux, 57\%. (ii) $\mathrm{BBr}_{3}$, $\mathrm{CH}_{2} \mathrm{Cl}_{2}$.

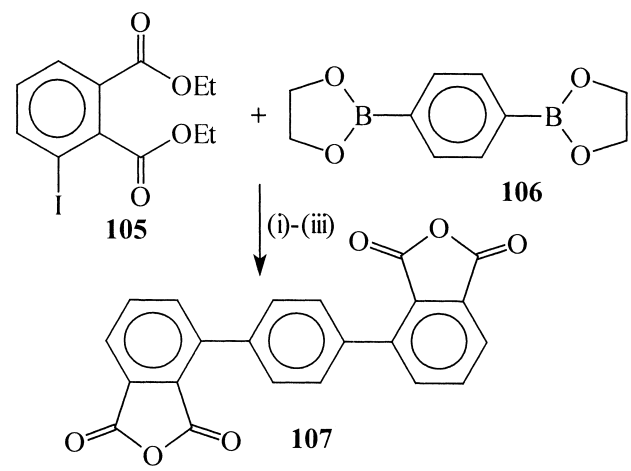

Scheme 55. (i) $\mathrm{Pd} / \mathrm{C}$ ( $5 \mathrm{~mol} \%$ ), $\mathrm{Cs}_{2} \mathrm{CO}_{3}, \mathrm{EtOH}, 79 \%$. (ii) $\mathrm{KOH} / \mathrm{EtOH}, \mathrm{H}_{2} \mathrm{O}$, $96 \%$. (iii), $\mathrm{Ac}_{2} \mathrm{O}, 98 \%$. derivatives (e.g. 104) have been prepared by using the SM cross-coupling protocol of 4,4'-dibromo-1,1'-biphenyl 102 and 2,3-dimethoxyphenylboronic acid 103 under $\mathrm{Pd}\left(\mathrm{PPh}_{3}\right)_{4}$ catalyst conditions followed by a deprotection sequence (Scheme 54). ${ }^{158}$

Mandal and co-workers have demonstrated the synthesis of dianhydrides e.g. 107 by a Pd/C-catalysed SM crosscoupling reaction between diethyl 3-iodophthalate $\mathbf{1 0 5}$ and the benzenediboronate ester 106, followed by a hydrolysis, acidification and dehydration sequence as depicted in Scheme 55. These dianhydrides were used for preparing thermostable polyimides. ${ }^{159}$

Beyerlein and co-workers synthesised the luminescent and photostable $\pi$-conjugated polymer building blocks 108 , 109a and 109b employing the SM cross-coupling reaction. ${ }^{160}$ Similarly, Dehaen's group developed both convergent and divergent approaches for the synthesis of highly soluble rod-like diketopyrrolopyrrole oligomers of specified length by using the $\mathrm{Pd}\left(\mathrm{PPh}_{3}\right)_{4}$-catalysed $\mathrm{SM}$ cross-coupling reaction of the diboronic ester $\mathbf{1 1 1}$ and the brominated 1,4-dioxo-3,6-diphenylpyrrolo[3,4-c]pyrroles (DPPs) 110a and 110b. An example of the convergent approach for the trimer of DPP $\mathbf{1 1 2}$ is included in Scheme 56. ${ }^{161}$ These compounds are useful for the construction of organic lightemitting devices.

In order to study the photoluminescent, optical absorption, mesomorphic and non-linear optical properties, terphenyl units of liquid crystalline monomers containing $\pi$-donoracceptor functional groups (e.g. cyano and nitro) $\mathbf{1 1 3}$ have been synthesised via the SM cross-coupling reaction (Scheme 57). ${ }^{162}$ Similarly, 1,4-bis-(2-bromo-4-methyl-5pyridyl)-benzene monomer $\mathbf{1 1 4}$ has also been synthesised by utilising the SM cross-coupling reaction (Scheme 58). ${ }^{163}$

Schlüter and co-workers ${ }^{164}$ have used sequential SM and Stille cross-coupling reactions for the synthesis of bifunctional oligoarylene and heteroarylene building blocks of the type 115 which are useful for modular chemistry (Fig. 10).

\subsection{Binaphthyl systems}

Chiral binaphthyl-based ligands are useful for enantio- and diastereo-selective synthesis of organic molecules. In this section, some recent examples of the synthesis of binaphthyl ligands via the SM cross-coupling reaction are discussed.

Widhalm and co-workers have used the $\mathrm{Pd}\left(\mathrm{PPh}_{3}\right)_{4}$-catalysed SM cross-coupling of the chiral binaphthylboronic acid 116 with aryl halides for synthesising sterically crowded binaphthylphosphine ligands (e.g. 117) which are useful for Pd-catalysed asymmetric allylic alkylation reactions (Scheme 59). ${ }^{165}$ In similar way, $\mathrm{Pu}$ et al. synthesised a fluorine-containing binapthyl ligand $\mathbf{1 2 0}$ by using the SM cross-coupling of the preformed binaphthylbased bispinacolboronate $\mathbf{1 1 8}$ with the fluorine-substituted halobenzene 119 (Scheme 60). ${ }^{166}$

These ligands are useful for the asymmetric addition of diphenylzinc to aldehydes. The poly(BINAP) ligand 123, which is useful for asymmetric hydrogenation, has been 


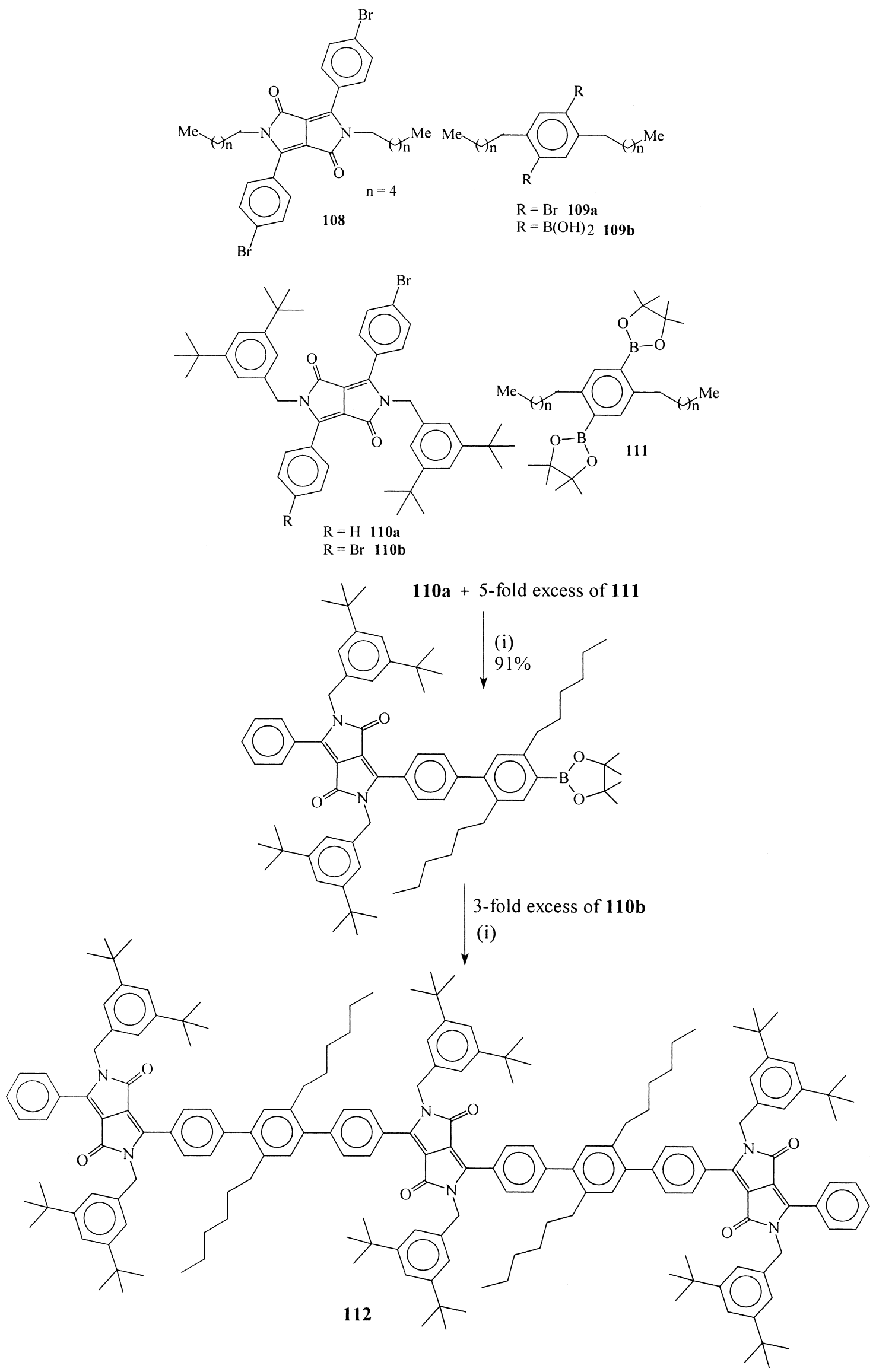

Scheme 56. (i) $\mathrm{Pd}\left(\mathrm{PPh}_{3}\right)_{4}, \mathrm{Na}_{2} \mathrm{CO}_{3}$, toluene, reflux. 


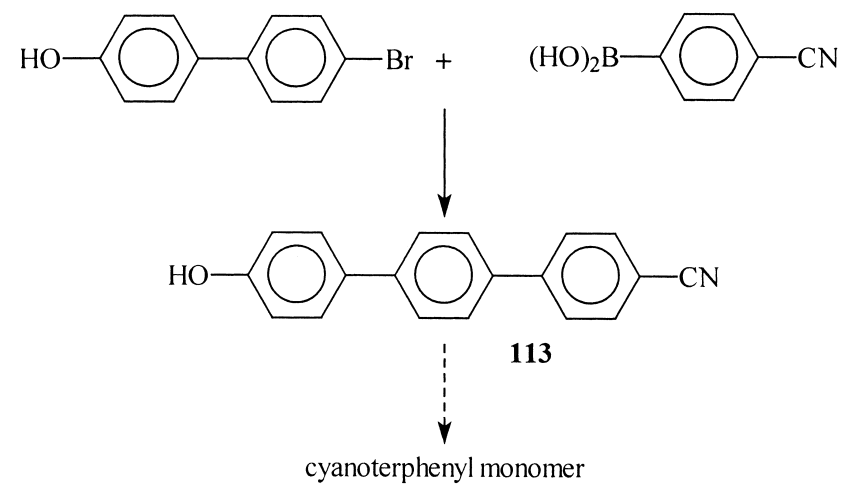

Scheme 57.

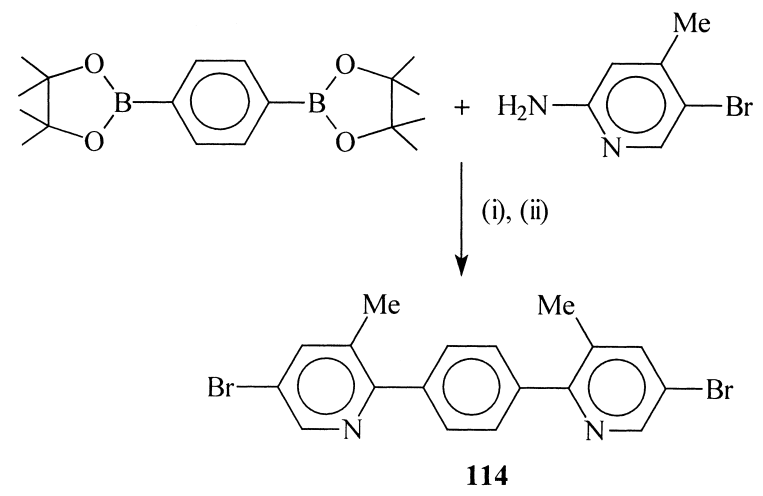

Scheme 58. (i) $\mathrm{Pd}\left(\mathrm{PPh}_{3}\right)_{4}, \mathrm{Na}_{2} \mathrm{CO}_{3}$, toluene, reflux, 60 h, $93 \%$. (ii) $\mathrm{NaNO}_{2}$, $\mathrm{HBr} /$ water, $\mathrm{AcOH}$.

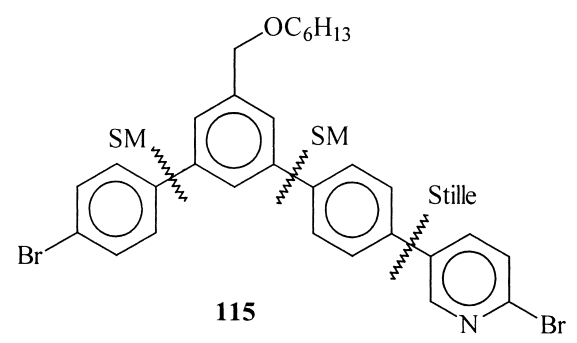

Figure 10. Bifunctional heteroarylene building block. synthesised by a $\mathrm{PdCl}_{2}$ (dppf)-catalysed SM cross-coupling reaction of the boronate ester $\mathbf{1 2 1}$ with the dibromide $\mathbf{1 2 2}$ as shown in Scheme 61. ${ }^{167}$

The reaction of the boronic acid $\mathbf{1 2 4}$ with the mesoternaphthylbistriflate $\mathbf{1 2 5}$ gave the coupled product $\mathbf{1 2 6}$ (Scheme 62) ${ }^{168}$ which was used for determining the chain length of $\alpha, \omega$-diamines with their picrate derivatives.

In connection with the synthesis of non-racemic $C_{2}$-symmetric 1,1'-binaphthyl-2,2'-diyl-bridged ferrocenes, Putala and co-workers observed the formation of the racemic $C_{2}$-symmetric binaphthyl-bridged ferrocene 129 with low yields by a $\mathrm{Pd}(\mathrm{dba})_{2}$-catalysed SM coupling reaction of $\mathbf{1 2 7}$ with 128 (Scheme 63). ${ }^{169}$ They also found a hydrodehalogenated product $\mathbf{1 3 0}$ from the corresponding dihalide $\mathbf{1 2 7}$ and oligomers of the coupling product when a $C_{2}$-symmetric palladacycle complex was used as the catalyst. Other reactions such as Negishi and Stille couplings gave the corresponding non-racemic products.

Hua et al. synthesised 8'-(4-methylphenyl)-8-[1-(1'-phenylthio)ferrocenyl]-1,1'-binaphthyl 133, a model compound for the preparation of charge-transfer complexes and $8^{\prime}$-iodo-8[1-(1'-phenylthio)ferrocenyl]-1,1'-binaphthyl 135, a precursor for the preparation of chiral phosphines by using a $\mathrm{Pd}\left(\mathrm{PPh}_{3}\right)_{4}$-catalysed SM cross-coupling reaction of their corresponding coupling partners131, 132 and 131, 134 respectively (Scheme 64). ${ }^{170}$

Green and co-workers synthesised atropoisomeric binaphthyls such as $\mathbf{1 3 8}$ to study their physical properties and racemisation kinetics by two different routes starting from 136 and 137 (Scheme 65). ${ }^{171}$

Brunner et al. synthesised a sterically hindered isoquinolinebased binaphthol 140 by using the Pd-catalysed SM crosscoupling reaction of 2-methoxy-1-naphthylboronic acid 139b and the corresponding heteroaromatic chloride 139a (Scheme 66). ${ }^{172}$<smiles>COc1c([18OH])cc2ccccc2c1-c1c(OC)c(Br)cc2ccccc12</smiles><smiles></smiles>

116<smiles></smiles><smiles>COc1c(-c2ccccc2)cc2ccccc2c1-c1c(OC)c(-c2ccccc2)cc2ccccc12</smiles> 


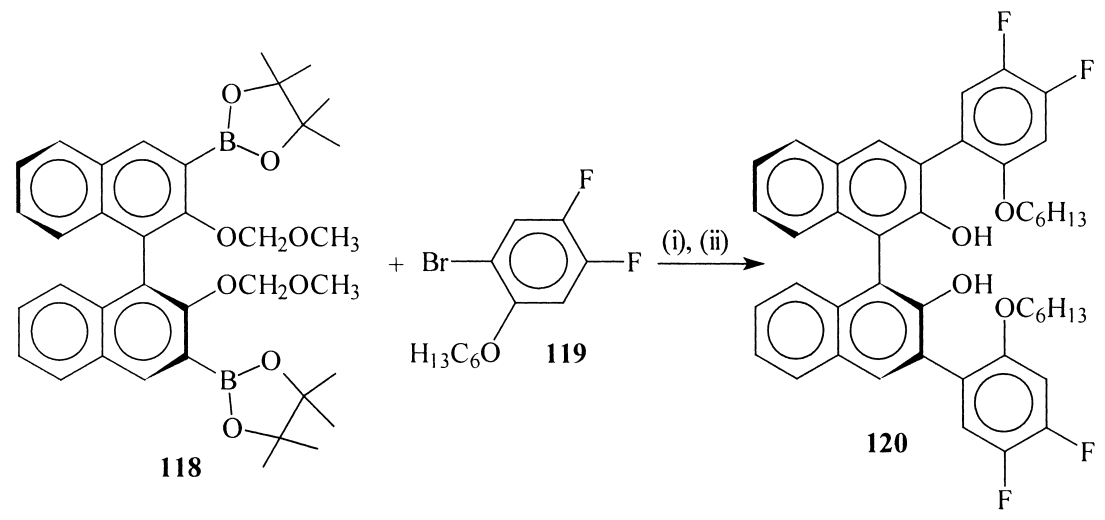

Scheme 60. (i) $\mathrm{Pd}\left(\mathrm{PPh}_{3}\right)_{4}$, aq. KOH, THF. (ii) 6N HCl, THF, reflux.

The $\mathrm{Pd}\left(\mathrm{PPh}_{3}\right)_{4}$-catalysed $\mathrm{SM}$ cross-coupling reaction between 4-choro-2-methyl-quinazoline 141 and 2-methoxy-1-naphthylboronic acid $\mathbf{1 3 9 b}$ gave the coupling product 142 which was transformed into enantiopure 2-methylquinazolinap 143, a new atropoisomeric phosphineamine ligand, by other functional group transformations and resolution (Scheme 67). ${ }^{173}$

Brown and co-workers reported the synthesis of bridged dimeric isoquinolylnaphthols such as $\mathbf{1 4 7}$ based on a $\mathrm{Pd}\left(\mathrm{PPh}_{3}\right)_{4^{-}}$or $\mathrm{Pd}_{2}(\mathrm{dba})_{3} \cdot \mathrm{CHCl}_{3}$-catalysed SM crosscoupling reaction of the chloroisoquinoline derivative 144 with the substituted binaphthylboronic acid 145 to give a key intermediate 146 followed by sequential functional group transformations (Scheme 68). ${ }^{174}$

\subsection{Multiple SM cross-couplings}

6.4.1. Symmetrical polyaryls using SM cross-couplings. Polyaryls have been important targets in synthetic organic chemistry for many years. They exhibit important biological properties and are useful building blocks in the synthesis of conducting polymers and macromolecules. Various polyaryl compounds prepared by a multiple SM cross-coupling reaction are shown in Fig. 11. Kuck and Tellenbröker have reported eight-fold functionalised fenestrindanes such as 148 by the SM cross-coupling reaction that can serve as an unusual motif for liquid crystalline materials, dendrimers and polycondensed ring systems with a saddle-like molecular structure. ${ }^{175}$ Rabideau and co-workers have prepared tetraphenylcorannulene $\mathbf{1 4 9}$ by using the SM

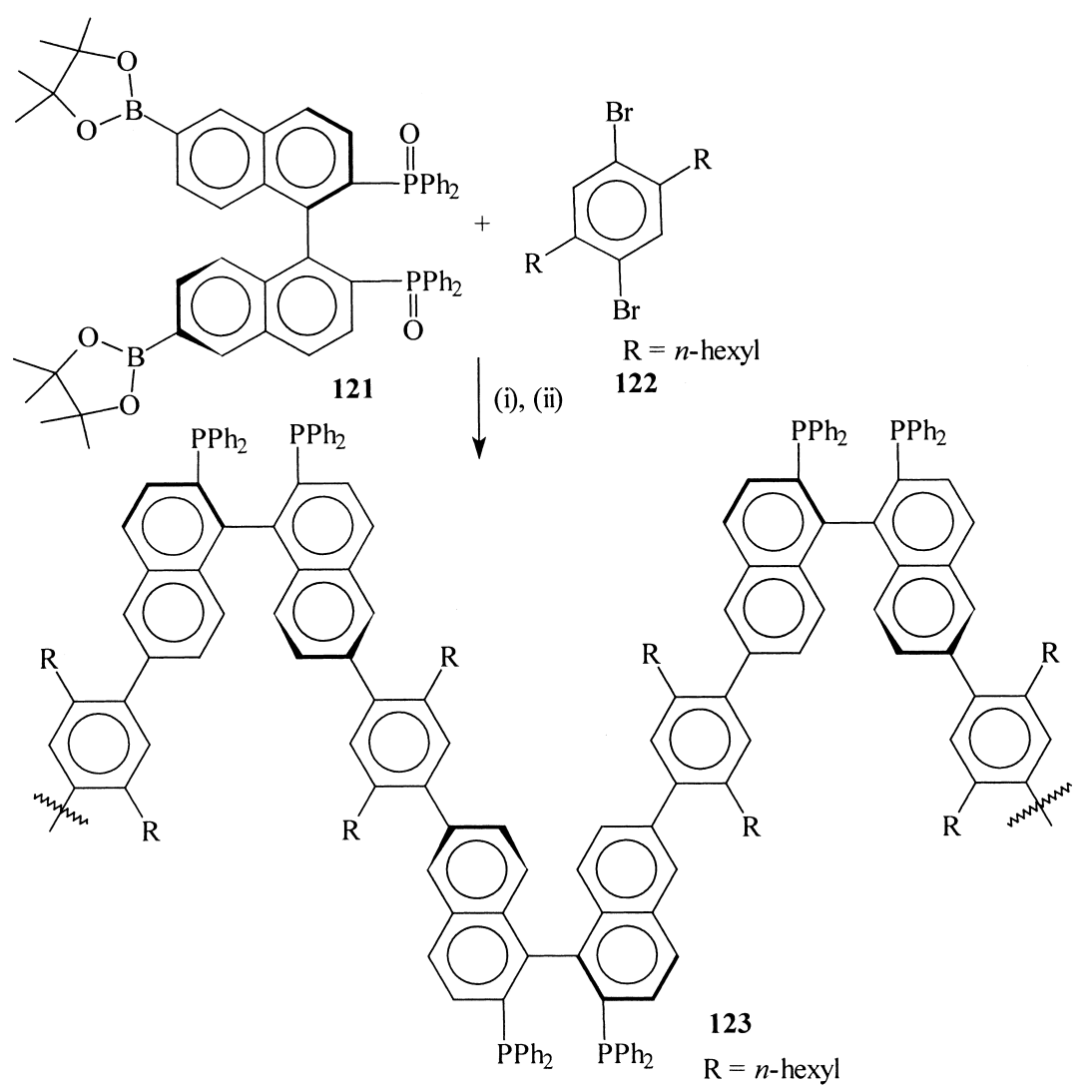

Scheme 61. (i) $\mathrm{PdCl}_{2}$ (dppf), aq. $\mathrm{K}_{2} \mathrm{CO}_{3}$. (ii) $\mathrm{HSiCl}_{3}, \mathrm{Et}_{3} \mathrm{~N}$, xylene, heat. 


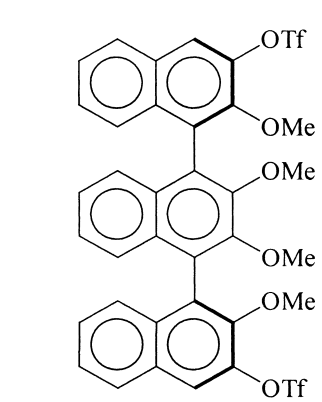

125<smiles>C=CCOc1c(Br)cc(Br)cc1COCCOCCOCCOCCO</smiles>

124
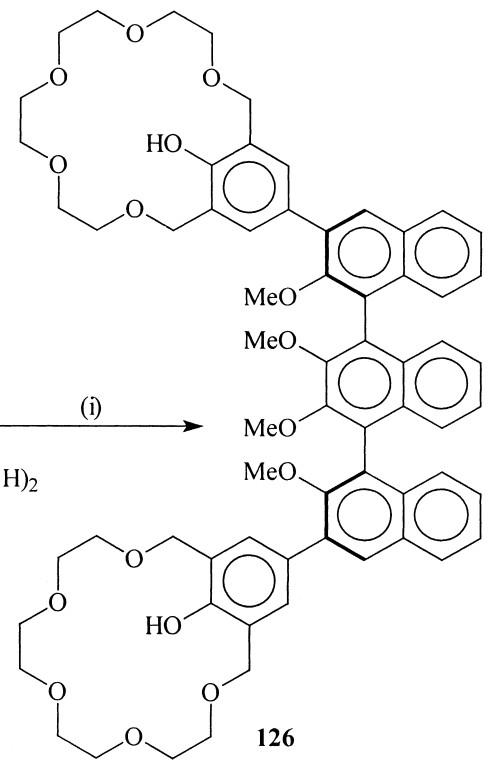

Scheme 62. (i) $\mathrm{Pd}\left(\mathrm{PPh}_{3}\right)_{4}, \mathrm{Na}_{2} \mathrm{CO}_{3}$, toluene-MeOH- $\mathrm{H}_{2} \mathrm{O}, 80^{\circ} \mathrm{C}, 26 \mathrm{~h}$, $80 \%$.

coupling methodology. ${ }^{176} s$-Triazines are effective ferromagnetic exchange linkers for $p$-( $t$-butylnitroxylphenyl) and $p$-phenoxyl groups. ${ }^{177}$ The central triazine core promotes planarity in the solid state for attached phenyl groups in comparison to the non-planar geometry found in systems with a central benzene core. In this regard, the trinitroxide 150 was prepared from cyanuric chloride using the SM cross-coupling reaction. Delia and Schomaker have prepared mono-, di- and triphenylpyrimidines (e.g. 151) depending on the reaction conditions. In addition, chloropyrimidine substrates are reported to be more preferable over iodo-, bromo- and fluoropyrimidines. ${ }^{178}$ In connection with synthesis of heteroaryl dendrimers, Kotha and co-workers have prepared mixed aryl-heteroaryl $C_{3}$-symmetric compounds such as 152 and 153 starting from 4-bromo- or 4-iodoacetophenone ${ }^{179}$ using a trimerisation reaction and the SM cross-coupling as key steps.

6.4.2. Porphyrins using $\mathrm{SM}$ cross-couplings. Porphyrins and metalloporphyrins are interesting targets for chemists working in the areas of organic synthesis, materials science, and bio-inorganic and organometallic chemistry. Substituted porphyrins are useful synthons in the construction of supramolecular assemblies that have a wide variety of applications. Recent applications of these systems include charge separation devices that mimic photosynthesis, materials for non-linear optical properties, chiral catalysts, synthetic receptors, potential sensitisers for photodynamic cancer therapy, liquid crystals and chiral sensors. In this regard, the SM cross-coupling reaction has proved to be a useful tool to generate diverse porphyrin structures. Some porphyrin-based assemblies 154-159 ${ }^{180-185}$ are shown in Fig. 12. The wavy lines indicate the actual $\mathrm{C}-\mathrm{C}$ bond formed during the SM cross-coupling reaction. Porphycenes, which have four coordination sites and have properties similar to porphyrins, were assembled by using the SM cross-coupling and McMurry coupling reactions as key steps (e.g. dioxadithioporphycene 159).

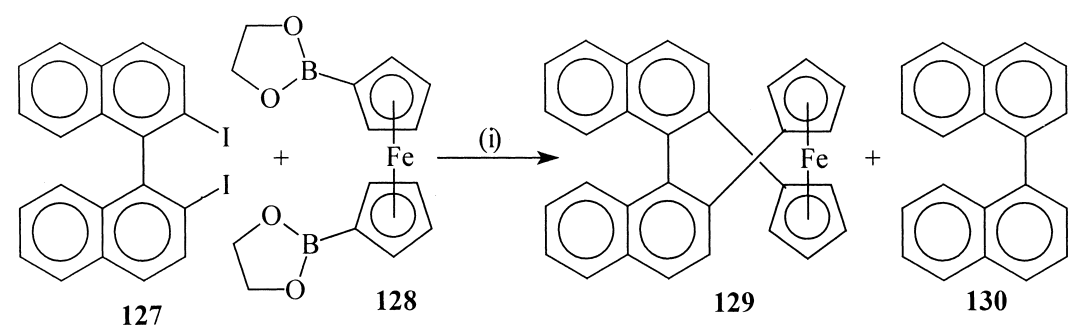

Scheme 63. (i) $\mathrm{Pd}(\mathrm{dba})_{2}, \mathrm{~K}_{3} \mathrm{PO}_{4}$, THF, reflux, $1 \mathrm{~h}, 12 \%$.
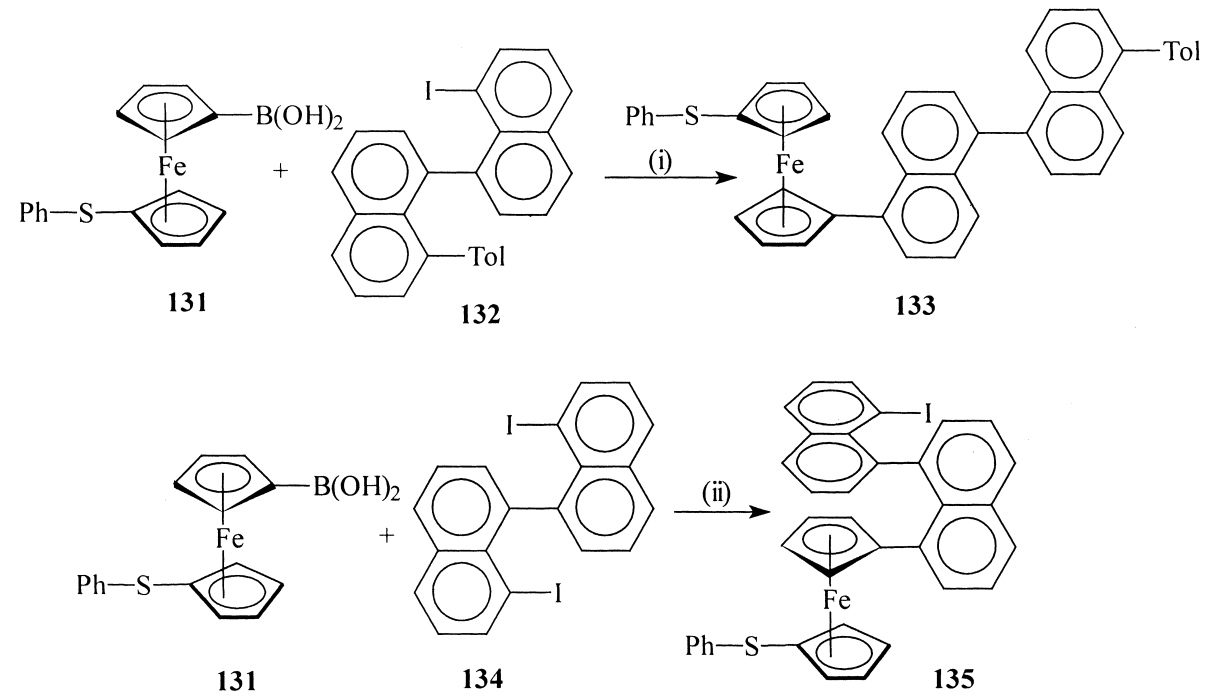

Scheme 64. (i) $\mathrm{Pd}\left(\mathrm{PPh}_{3}\right)_{4}, \mathrm{Na}_{2} \mathrm{CO}_{3}$, dioxane, $\mathrm{H}_{2} \mathrm{O}$. (ii) $\mathrm{Pd}\left(\mathrm{PPh}_{3}\right)_{4}, \mathrm{~K}_{3} \mathrm{PO}_{4}$, dioxane, $\mathrm{H}_{2} \mathrm{O}$. 


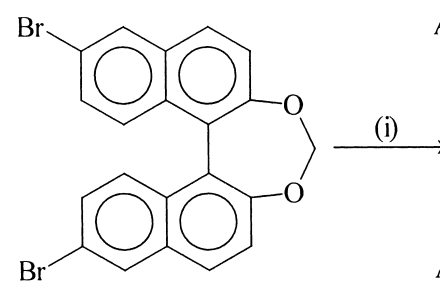

136

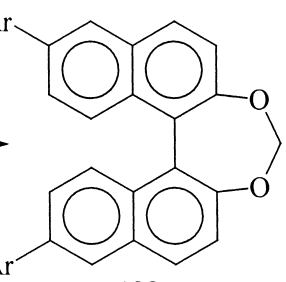

138

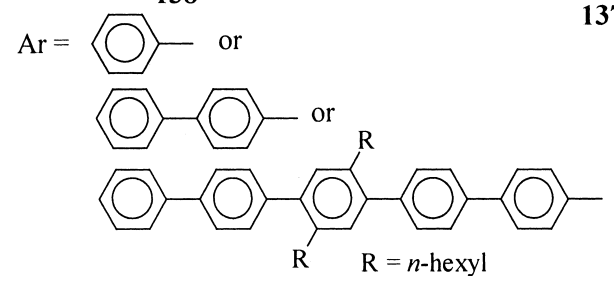

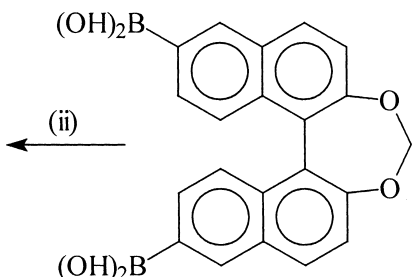

137

Scheme 65. (i) $\mathrm{ArB}(\mathrm{OH})_{2}, \mathrm{Pd}\left(\mathrm{PPh}_{3}\right)_{4}, \mathrm{Na}_{2} \mathrm{CO}_{3}$. (ii) $\mathrm{ArBr}, \mathrm{Pd}\left(\mathrm{PPh}_{3}\right)_{4}, \mathrm{Na}_{2} \mathrm{CO}_{3}$.

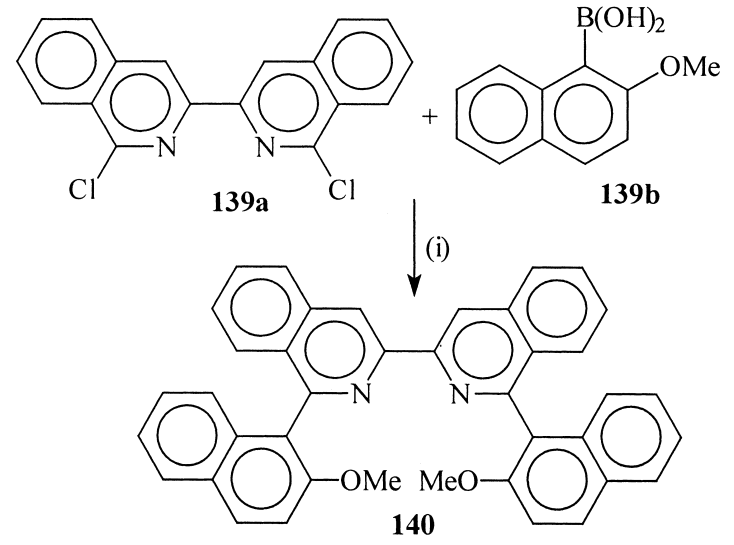

Scheme 66. (i) $\mathrm{Pd}\left(\mathrm{PPh}_{3}\right)_{4}(6 \mathrm{~mol} \%)$, ethylene glycol dimethyl ether, $\mathrm{Na}_{2} \mathrm{CO}_{3}$, reflux, $36 \mathrm{~h}, 42 \%$.

6.4.3. Thiophene derivatives using $S M$ cross-couplings. Substituted thiophenes are valuable building blocks for many natural and non-natural products and enjoy potential applications in the flavour and pharmaceutical industries and in materials science. More specifically, polythiophenes exhibit interesting electric and non-linear optical properties.

Morgado and co-workers have prepared a series of novel alternating polymers of the type A-alt-B 160, where $\mathrm{A}$ is 9,9-bis( $2^{\prime}$-ethylhexyl)fluorene and $\mathrm{B}$ is an extended thiophene-based moiety, via a Pd-catalysed SM cross-coupling reaction (Fig. 13). ${ }^{186}$
2,3-Dibromothiophene undergoes a regioselective $\operatorname{Pd}(0)$ catalysed SM cross-coupling reaction at the $\mathrm{C}_{2}$ position with different boronic acids (Scheme 69). ${ }^{187}$ Further substitution at the $\mathrm{C}_{3}$ position was achieved by using a modified Stille reaction to afford 2,3-disubstituted thiophenes. Sampson and co-workers have employed a similar regioselective SM cross-coupling reaction for the construction of a fluorothiophene-containing mesogen $\mathbf{1 6 1}^{188}$ that is useful in the synthesis of liquid crystalline materials (Fig. 13).

Terthiophene aldehydes and phosphates such as $\mathbf{1 6 2}$, which are key building blocks for the synthesis of functionalised conducting polymers, were assembled by the SM crosscoupling reaction. ${ }^{189}$ Donor-acceptor substituted $\alpha$-oligothiophenes, e.g. 163 with anthracene as the donor and $\mathrm{C}_{60}$ (fullerene) as the acceptor have been synthesised via a [4+2] cycloaddition reaction of $\mathrm{C}_{60}$ with the heteroanalogous $o$-quinodimethanes of anthryloligothiophenes. The anthryloligothiophene was assembled by the SM crosscoupling reaction. ${ }^{190}$

Müller and co-workers have reported the synthesis of phenothiazinyl diads and triads with variable functionalisation in good yields by SM cross-coupling with suitable phenothiazinyl boronates. ${ }^{191}$ One such example is $\mathbf{1 6 4}$ (Fig. 13) and these heterocyclic oligomers are strongly coupled electronically and represent suitable functional units for novel redox-active molecular wires.

Kotha and co-workers ${ }^{192}$ have employed a Pd-catalysed SM
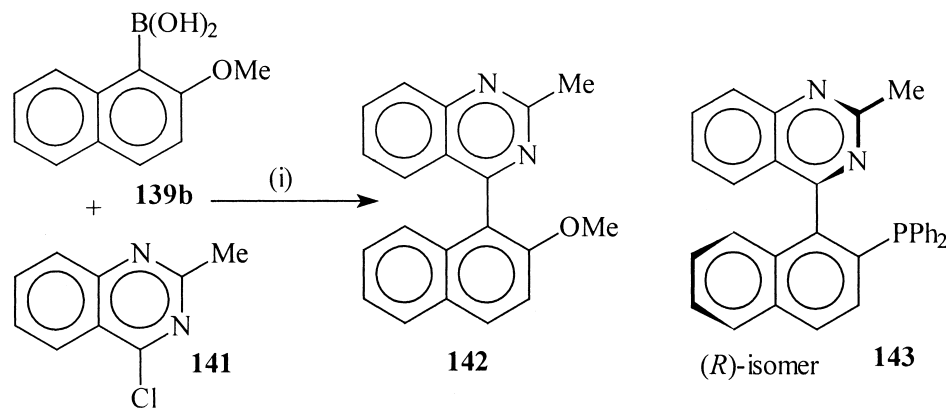

$(R)$-isomer 


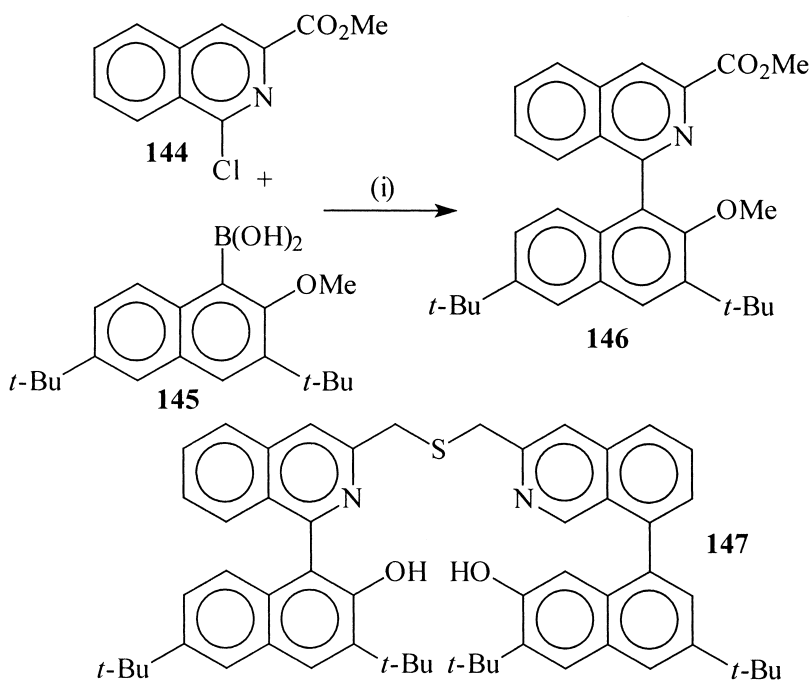

Scheme 68. (i) $\mathrm{Pd}(\mathrm{dba})_{3} \cdot \mathrm{CHCl}_{3}$, tri-2-furylphosphine, $\mathrm{K}_{2} \mathrm{CO}_{3}, \mathrm{DME}, 75 \%$.

cross-coupling reaction of $\mathbf{1 6 5}$ and thiopheneboronic acid to prepare the thiophene derivative $\mathbf{1 6 6}$ which on trimerisation with $\mathrm{SiCl}_{4}$ gave the $C_{3}$ symmetric molecule $\mathbf{1 5 3}$ (Scheme 70). By adopting a similar strategy, coupling of 2-acetyl-5-bromothiophene 167 and phenylboronic acid gave the thiophene derivative $\mathbf{1 6 8}$ which undergoes a trimerisation reaction in presence of $\mathrm{SiCl}_{4}$ to give 169. It is interesting to note that, by adopting the proper choice of reaction sequence, arylthienyl oligomers can be prepared where the thiophene unit is present either in the inner or the outer core of the molecule.

\subsection{Asymmetric SM cross-coupling reactions}

The SM cross-coupling reaction has also been applied to the stereoselective or atroposelective synthesis of axially chiral biaryl systems with either $\mathrm{P}$ or $\mathrm{M}$ configuration.

Nicolaou and co-workers reported the first asymmetric version of the SM cross-coupling reaction in connection with the total synthesis of vancomycin, a peptide-based antibiotic drug. ${ }^{193}$ Many additional examples including the stereoselective synthesis of the natural product, (-)-steganone, by Uemura ${ }^{194}$ and other chiral biaryl systems by Buchwald ${ }^{195}$ and Crépy ${ }^{196}$ have subsequently appeared in the literature and are covered in recent reviews. ${ }^{197-199}$

Whiting et al. attempted the prevention of atropoisomeric interconversion by synthesising sterically hindered 1,8-diarylnaphthalenes and 5,6-diarylacenaphthenes 172 involving the $\mathrm{Pd}\left(\mathrm{PPh}_{3}\right)_{4}$-catalysed SM cross-coupling reaction of the 1,8-dibromonaphthalene or 5,6-dibromoacenaphthenes $\mathbf{1 7 0}$ and the appropriate boronic acids such as $\mathbf{1 7 1}$ (Scheme 71). ${ }^{200}$

Shibasaki and co-workers have reported a simple method for the generation of chiral cyclopentane derivatives such as 176. Their strategy involves the Pd-catalysed intramolecular coupling of the prochiral alkylboron derivative 175 (resulting from the hydroboration of terminal alkenes in the prochiral triflate $\mathbf{1 7 4}$ or bromide) in the presence of chiral binaphthyl-and ferrocenylphosphine ligands such as $\mathbf{1 7 3}$ followed by oxidative work up with moderate yields and low enantiomeric excess (Scheme 72). ${ }^{201}$
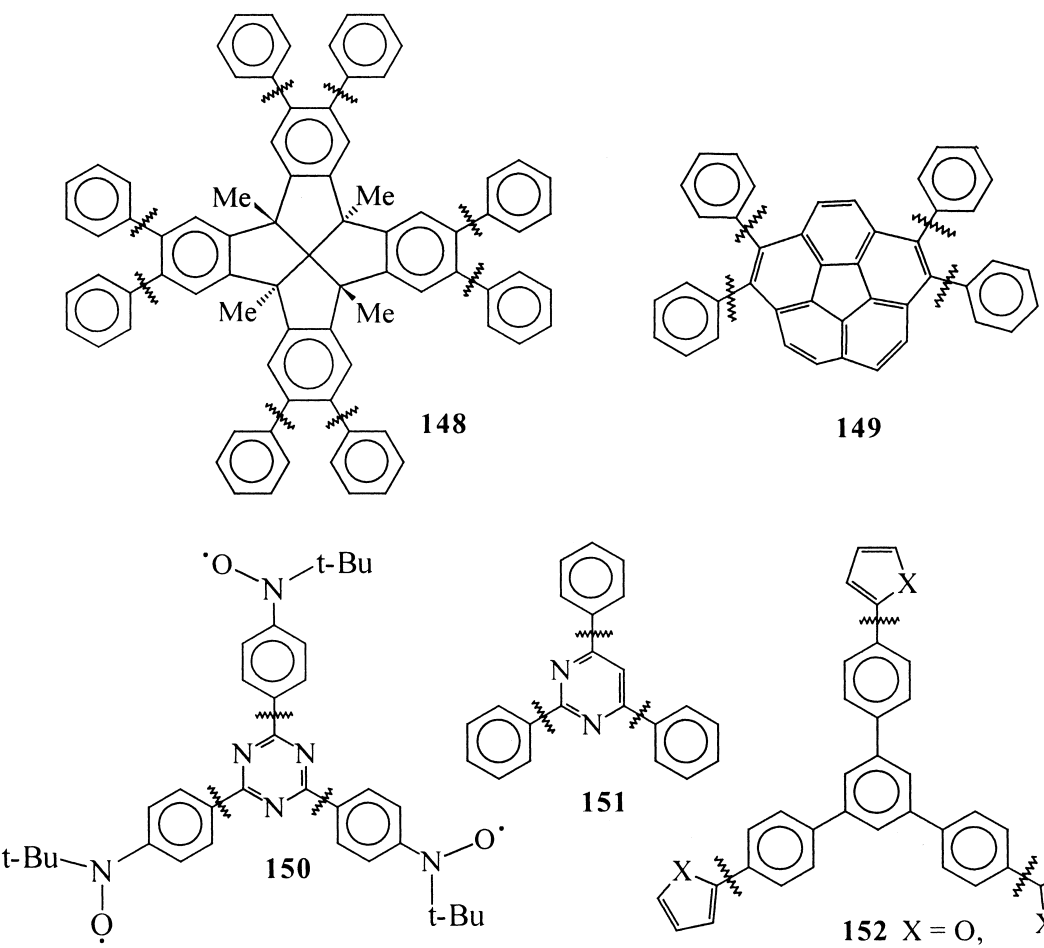

149 


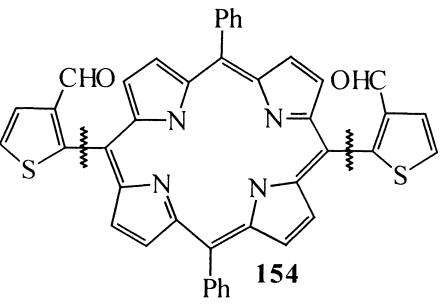

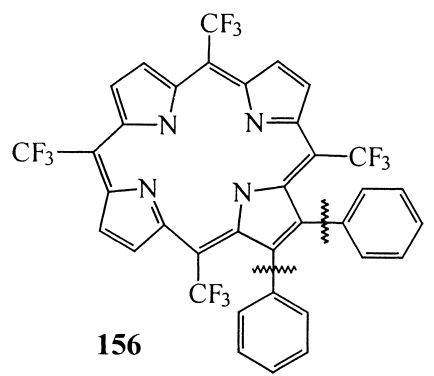

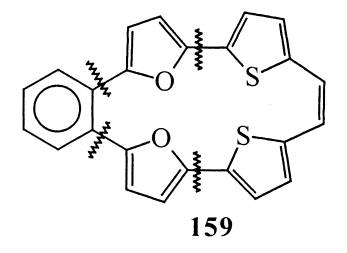

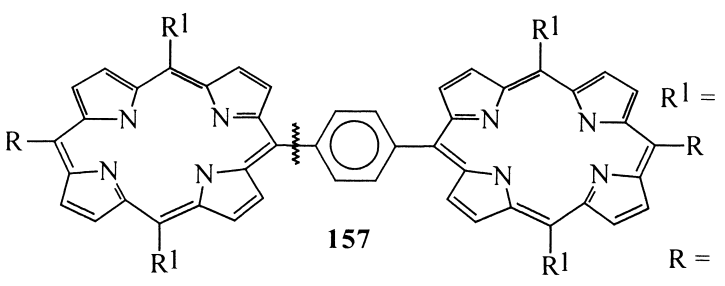

$\mathrm{t}-\mathrm{Bu}$<smiles>Cc1cc(C)cc(Br)c1</smiles><smiles>Cc1cc(C)c(C)c(C)c1</smiles>

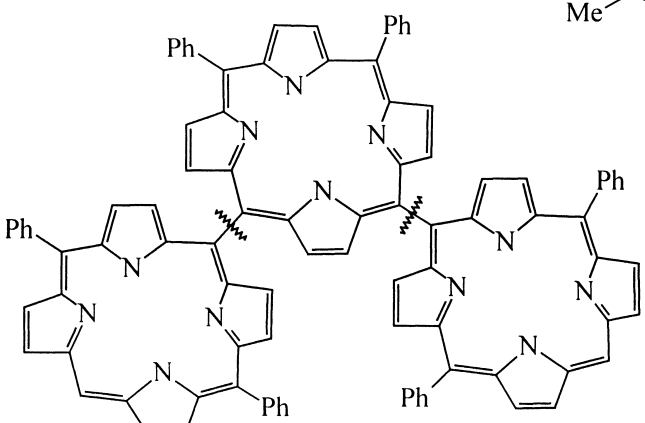

158

Figure 12. Substituted porphyrins synthesised by the SM cross-coupling reaction.

\section{Dendrimer synthesis via the SM cross-coupling}

Dendrimers are well-defined macromolecules exhibiting a regularly branched architecture. They are useful in drug delivery systems where they act as ion channels and aids in the transportation of drug molecules to the desired site. They are also very important entities in materials chemistry, polymers and energy transfer systems. Some recent advances in the synthesis of dendrimers where the SM cross-coupling reaction has been utilised will be presented here.

Kimura and co-workers synthesised 1,3,5-phenylene-based metallodendrimers containing a $\mathrm{Ru}(\mathrm{II})$ complex located at an interior core of 180 by using the $\mathrm{Pd}\left(\mathrm{PPh}_{3}\right)_{4}$-catalysed SM cross-coupling reaction of the preformed dendron boronic acid 177 or 178 with 3,8-dibromo-1,10-phenanthroline 91 to give 179, which on treatment with $\mathrm{RuCl}_{2}$ (bipy) $)_{2}$ resulted in the formation of $\mathbf{1 8 0}$ (Scheme 73). ${ }^{202}$ The fluorescence and absorption studies of these compounds indicate that they can be used as organic light-emitting diodes.

$\mathrm{Pu}$ and co-workers reported the synthesis of a chiral micellelike dendrimer 183, having a chiral binaphthyl unit as the central core, meta-phenylene dendrons, and polyhydroxy groups at the periphery by using the $\mathrm{Pd}\left(\mathrm{PPh}_{3}\right)_{4}$-catalysed reaction of the pinacol boronate $\mathbf{1 8 1}$ with the tetrabromo derivative of the chiral binaphthyl $\mathbf{1 8 2}$ followed by hydrolysis (Scheme 74). ${ }^{203}$

The functionalised chiral ferrocene derivative $\mathbf{1 8 6}$ has been prepared by the $\mathrm{Pd}(\mathrm{OAc})_{2}$-catalysed reaction of 4-methoxyphenylboronic acid 184 with $(S)$-2-iodoferrocenecarboxaldehyde 185, which was introduced into the periphery of a phosphorous-containing chiral dendrimer by further sequential reactions (Scheme 75). ${ }^{204}$ Zhang and co-workers used coloured dendrimers as soluble supports for the SM cross-coupling reaction. ${ }^{205}$ 

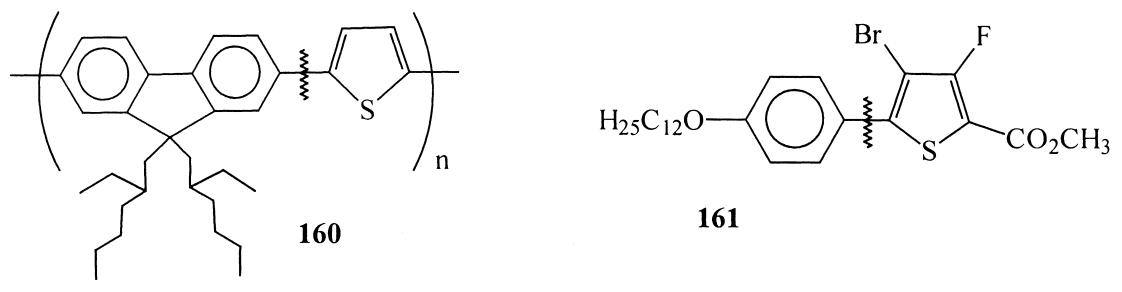

161

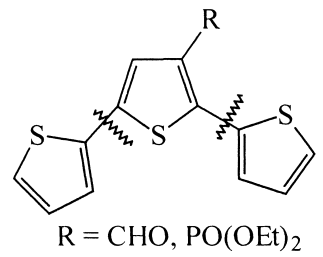

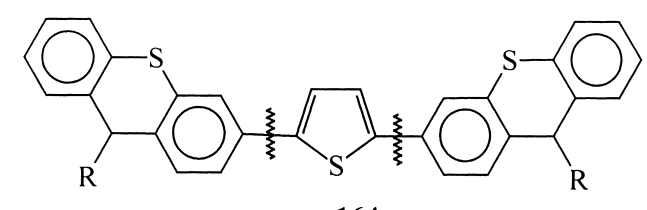

162

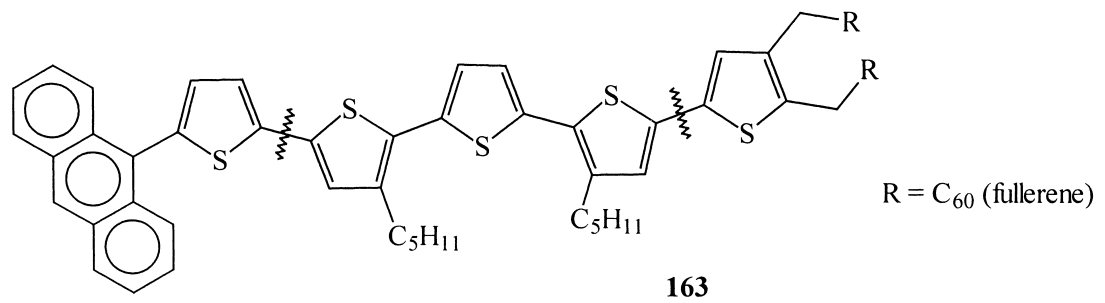

Figure 13. Various thiophene derivatives prepared by the SM cross-coupling reaction.

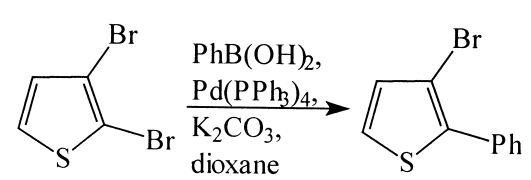

Scheme 69.

\section{Synthesis of unusual amino acids and peptides}

In recent years, the synthesis of unusual $\alpha$-amino acids (AAAs) has attracted a significant amount of attention from organic chemists as new medicinal targets emerge. The replacement of proteinogenic AAA by unusual and/or constrained analogues of AAAs can lead to peptidomimetics of<smiles>Cc1ccc(Br)cc1</smiles><smiles>[R][R]c1cccc(-c2ccc(C)s2)c1</smiles>

Scheme 70. (i) Thiopheneboronic acid, $\mathrm{Pd}\left(\mathrm{PPh}_{3}\right)_{4}, \mathrm{~K}_{2} \mathrm{CO}_{3}, \mathrm{H}_{2} \mathrm{O}$, DME. (ii) $\mathrm{SiCl}_{4}$, EtOH. (iii) $\mathrm{PhB}(\mathrm{OH})_{2}, \mathrm{Pd}_{(}\left(\mathrm{PPh}_{3}\right)_{4}, \mathrm{~K}_{2} \mathrm{CO}_{3}, \mathrm{H}_{2} \mathrm{O}, \mathrm{DME}$.<smiles>Brc1ccc2c3c(ccc(Br)c13)CC2</smiles>

170

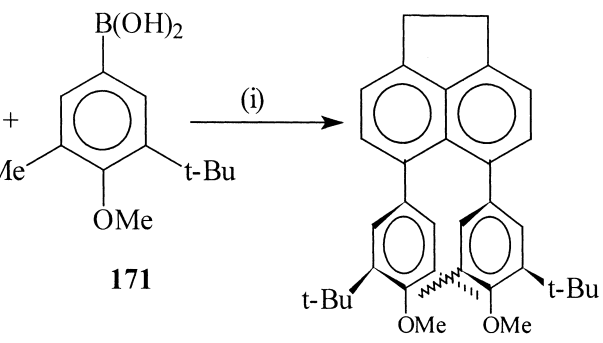

172

enhanced biological activity and also increases the proteolytic stability. In this respect, the SM cross-coupling reaction has been found to be useful to generate a library of unusual AAAs.

Various biphenylalanine derivatives have been prepared via the SM cross-coupling reaction as a key step. In this regard, the benzophenone imine of (4-pinacolylborono)phenylalanine ethyl ester 187 undergoes the SM cross-coupling reaction under $\mathrm{PdCl}_{2}(\mathrm{dppf})$ and $\mathrm{K}_{3} \mathrm{PO}_{4}$ conditions with aryl iodides, bromides, chlorides and triflates to give the 4-substituted phenylalanine (Phe) derivatives $\mathbf{1 8 8}$ in high 
<smiles>CC(c1ccccc1)C(C)c1ccccc1</smiles>

173

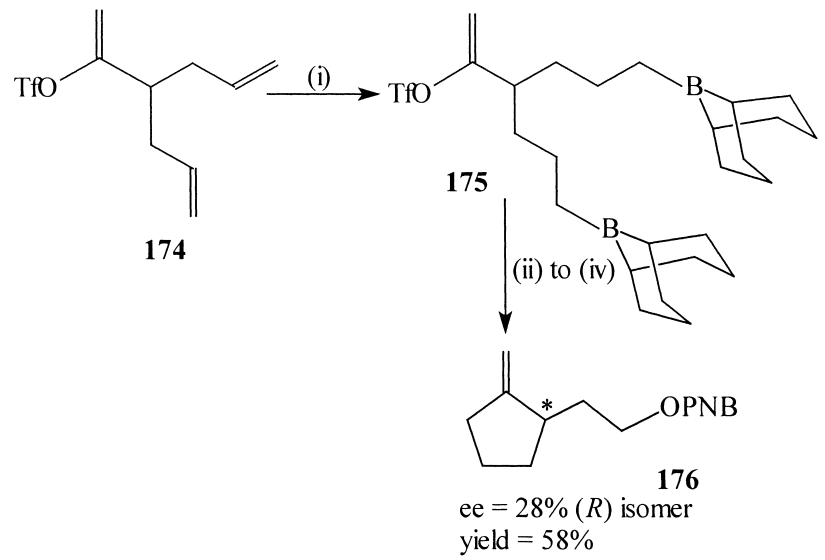

Scheme 72. (i) 9-BBN, THF. (ii) $\mathrm{Pd}_{2}(\mathrm{dba})_{3}(10 \mathrm{~mol} \%)$, ligand 173 (20 mol\%), $\mathrm{K}_{2} \mathrm{CO}_{3}$, THF, $40^{\circ} \mathrm{C}$. (iii) $3 \mathrm{~N} \mathrm{NaOH}, \mathrm{H}_{2} \mathrm{O}_{2}$. (iv) $p$-nitrobenzoyl chloride, $\mathrm{Et}_{3} \mathrm{~N}, \mathrm{CH}_{2} \mathrm{Cl}_{2}$.

yields (Scheme 76). ${ }^{206-208}$ This methodology was extended with Seebach's chiral auxiliary $\mathbf{1 8 9}$ to prepare the corresponding chiral derivatives such as 190 (Scheme 77). With aryl chlorides, $\mathrm{PdCl}_{2}\left(\mathrm{PCy}_{3}\right)_{2}$ or $\mathrm{NiCl}_{2}(\mathrm{dppf})$ catalysts are found to be useful for the coupling reaction. Yamamoto $^{209}$ developed a practical method for the synthesis of enantiomerically pure 4-borono-L-phenylalanine from L-tyrosine or 4-iodo-L-phenylalanine derivatives using the $\mathrm{Pd}$-catalysed coupling reaction with pinacolborane.

The Garner aldehyde $\mathbf{1 9 1}$ has proved to be a useful starting material for the preparation of various unusual AAA derivatives. In this respect, Taylor and co-workers have found that an organoborane reagent is an excellent homoalanine anion equivalent that can be transformed into a range of unusual AAA derivatives (e.g. 192)

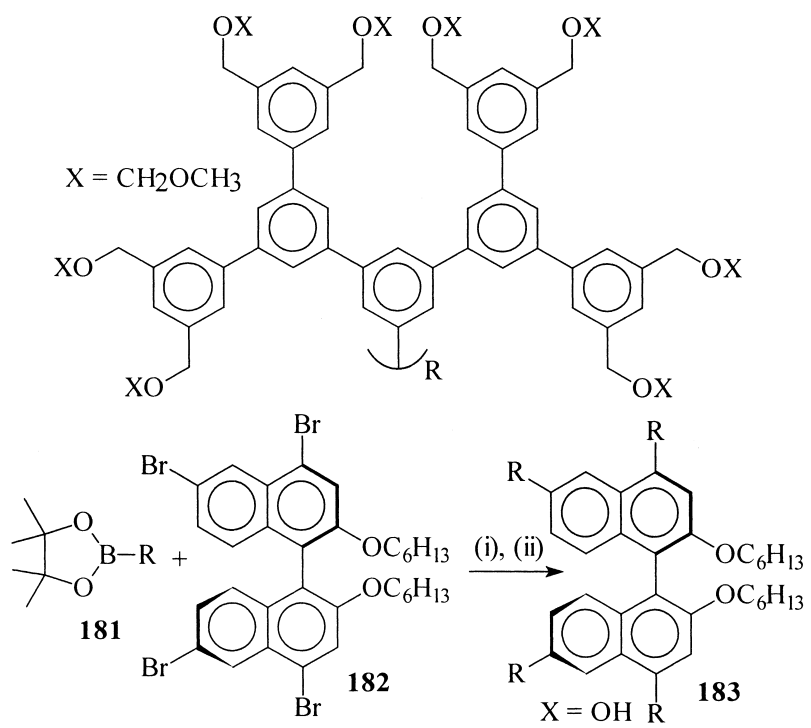

Scheme 74. (i) $\mathrm{Pd}\left(\mathrm{PPh}_{3}\right)_{4}(10 \mathrm{~mol} \%), \mathrm{K}_{2} \mathrm{CO}_{3}$, THF, reflux, $47 \mathrm{~h}, 67 \%$. (ii) $6 \mathrm{~N} \mathrm{HCl}, \mathrm{CHCl}_{3} / \mathrm{EtOH}$, reflux, $24 \mathrm{~h}, 80 \%$.
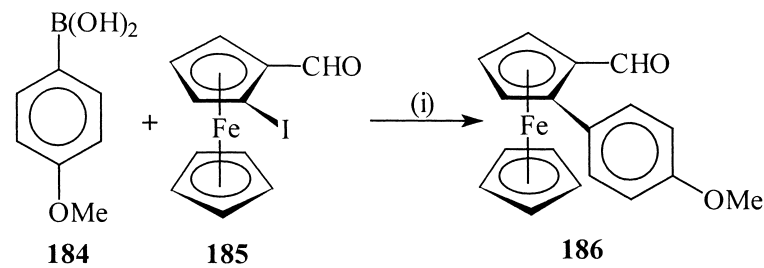

186

Scheme 75. (i) $\mathrm{Pd}(\mathrm{OAc})_{2}, \mathrm{Ba}(\mathrm{OH})_{2}, \mathrm{H}_{2} \mathrm{O}$.<smiles>CCOC(=O)C(Cc1ccc(B2OC(C)(C)C(C)(C)O2)cc1)N=C(c1ccccc1)c1ccccc1</smiles>

187<smiles>CCOC(=O)C(Cc1ccc([Al])cc1)N=C(c1ccccc1)c1ccccc1</smiles>

188
Scheme 76. (i) $\mathrm{ArX}(\mathrm{X}=\mathrm{I}, \mathrm{OTf}, \mathrm{Br}, \mathrm{Cl}), \mathrm{PdCl}_{2}(\mathrm{dppf}), \mathrm{K}_{3} \mathrm{PO}_{4}$, DME, reflux.
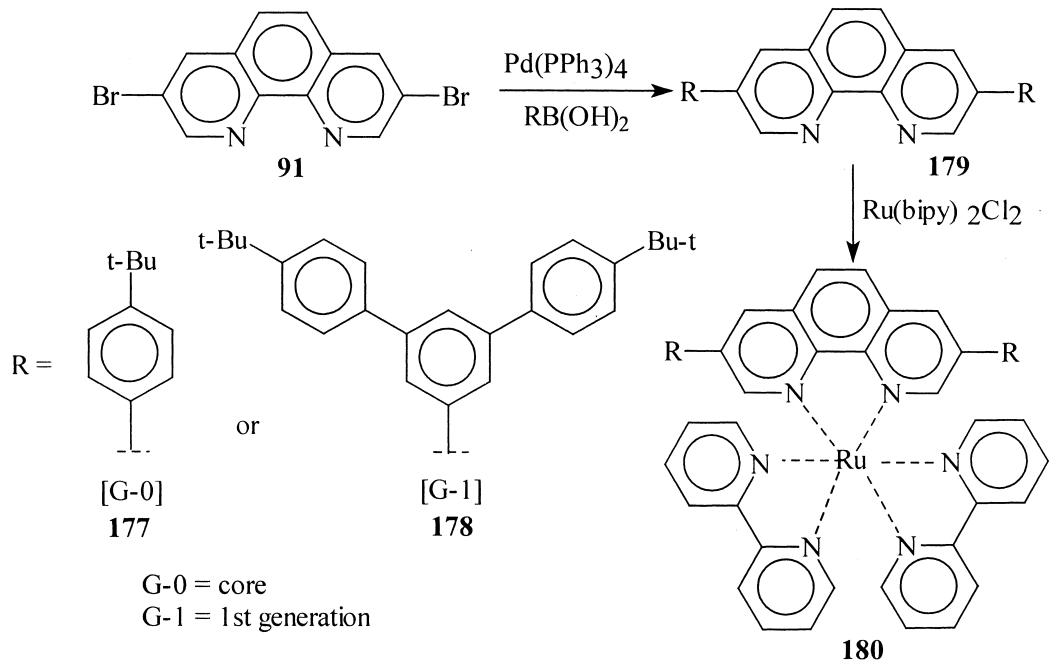

Scheme 73. 
189

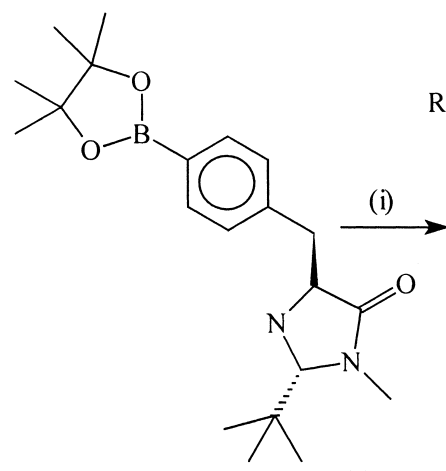

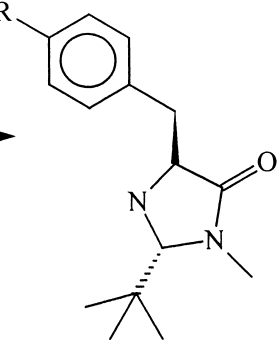

190
Scheme 77. (i) $\mathrm{RX}(\mathrm{R}=$ vinyl or aryl; $\mathrm{X}=\mathrm{Br}, \mathrm{I}), \mathrm{PdCl}_{2}$ (dppf), $\mathrm{Ba}(\mathrm{OH})_{2} \cdot 8 \mathrm{H}_{2} \mathrm{O}$, DME/water (1:1), reflux.

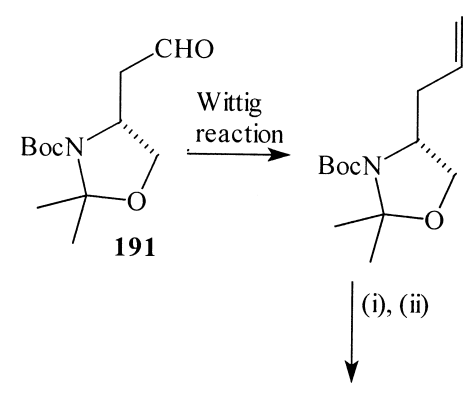

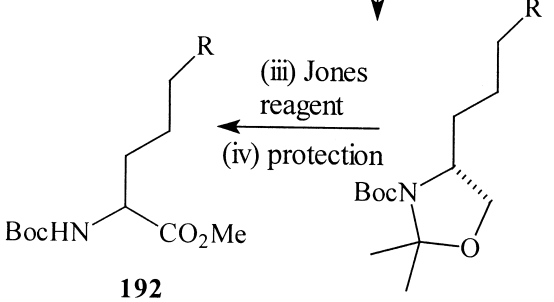

Scheme 78. (i) 9-BBN, THF. (ii) $\mathrm{RX}$ ( $\mathrm{R}=$ vinyl or aryl; $\mathrm{X}=\mathrm{I}, \mathrm{Br}$, OTf), $\mathrm{PdCl}_{2}(\mathrm{dppf}), \mathrm{K}_{3} \mathrm{PO}_{4}$, DMF.

(Scheme 78). ${ }^{210,211}$ This strategy has been extended to the synthesis of a wide range of homophenylalanines, bishomophenylalanines and meso-2,6-diaminopimelic acid.

Chiral and geometrically well-defined 5,5-diaryl-2-amino4-pentenoates, e.g. 194 have been prepared under the SM cross-coupling conditions (Scheme 79). ${ }^{212}$ Allylation of the Schiff base with an allyl bromide in the presence of LDA afforded the key intermediate $\mathbf{1 9 3}$ that can be reacted with various boronic acids to give the desired compounds.

Unnatural AAAs containing boron are useful for boron

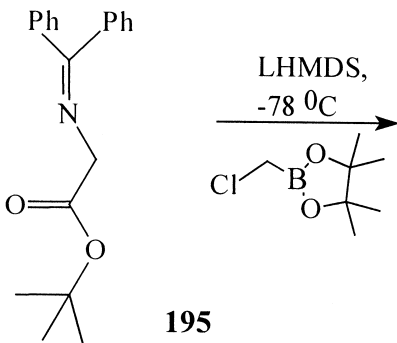<smiles>CC(C)(C)OC(=O)C(CB1OC(C)(C)C(C)(c2ccccc2)O1)N=C(c1ccccc1)c1ccccc1</smiles>

Scheme 80.

neutron capture therapy (BNCT) of brain tumors. In this regard, an orthogonally protected boronic acid analogue of aspartic acid 196 (Scheme 80) ${ }^{213}$ where the side chain carboxylic acid is replaced with a boronic acid moiety has been synthesised by the alkylation of the Schiff base $\mathbf{1 9 5}$ with pinacol(chloromethyl)boronate in the presence of lithium hexamethyldisilazide (LHMDS) at $-78^{\circ} \mathrm{C}$.

Clinical studies indicate that boron-containing AAAs are useful for the treatment of cancer and it is believed that the unusual AAAs are preferentially taken up by growing tumor cells. Kabalka et al. prepared 1-amino-3-boronocyclopentanecarboxylic acid 197 and 1-amino-3-boronocycloheptanecarboxylic acid $\mathbf{1 9 8}$ as potential therapeutic agents using the Bucher-Berg reaction as a key step (Fig. 14)..$^{214}$

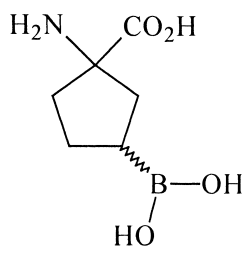

197

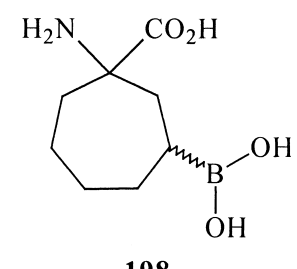

198
Figure 14. Boron-containing AAAs with useful applications in the treatment of cancer.

1,2,3,4-Tetrahydroisoquinoline-3-carboxylic acid (Tic) is an important structural element used in ACE and renin inhibitors and in bradykinin and opioid antagonists. Functionalised Tic derivatives are difficult to prepare by the standard methods such as Pictet-Spengler cyclisation and the SM cross-coupling reaction has been applied to generate 6- and 8-substituted Tic derivatives (e.g. 200)<smiles>CC#CCC(=O)CN=C(c1ccccc1)c1ccccc1</smiles><smiles>CC(=O)C(CC=C(C)I)N=C(c1ccccc1)c1ccccc1</smiles><smiles>CC(=O)C(CC=C([Al])[Al])N=C(c1ccccc1)c1ccccc1</smiles>

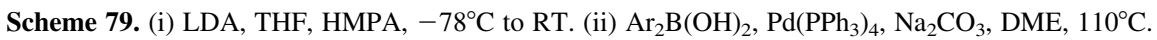


<smiles>CCOC(=O)C1Cc2cc(Oc3ccccc3)ccc2CN1C(=O)OC(C)=O</smiles>

Scheme 81. (i) $\mathrm{PhB}(\mathrm{OH})_{2}, \mathrm{Pd}\left(\mathrm{PPh}_{3}\right)_{4}, \mathrm{~K}_{3} \mathrm{PO}_{4}, \mathrm{DMF}, 100^{\circ} \mathrm{C}$.

starting from the corresponding triflates (e.g. 199) (Scheme 81). ${ }^{215}$

Danion et al. have reported that protected vinylboronic AAAs such as $\mathbf{2 0 1}$ readily undergo the SM cross-coupling reaction with aromatic or vinyl bromides (Scheme 82). ${ }^{216}$

Phenylalanine (Phe) is an important structural component in many biologically active peptides. There are several examples in the literature which show that, when Phe is replaced by various constrained analogues, the resulting peptides show enhanced biological activity and pronounced proteolytic stability. In this regard, the indanes $\mathbf{2 0 3}$, dibenzylglycine derivatives such as 204 and tetralin-based AAAs 205 that are constrained analogues of Phe are important synthetic targets (Fig. 15). The conventional Bucherer-Berg method used for the preparation of these cyclic AAAs provides only a limited number of derivatives.

In this respect, Kotha and co-workers realised that the SM cross-coupling reaction is useful to generate various unusual AAA derivatives. Towards this goal, the preparation of indane-based AAA derivatives was undertaken and the key AAA derivative $\mathbf{2 0 6}$ was prepared as shown in Scheme 83..$^{217}$ The SM cross-coupling reaction of $\mathbf{2 0 6}$ with several boronic acid derivatives using $\left(\mathrm{PPh}_{3}\right)_{4} \mathrm{Pd}$ as the catalyst gave typically $62-99 \%$ yields of the coupling products 207.

Along similar lines, ethyl isocyanoacetate was alkylated with $p$-iodobenzyl bromide under phase-transfer catalysis (PTC) conditions to generate the key $N$-Boc derivative 208 (Scheme 84). ${ }^{218}$ SM cross-coupling of the diiodo compound 208 with various boronic acids gave the biaryls 209 in good yield. Using the SM cross-coupling reaction, various 6,7-diaryltetralins (e.g. 211) were prepared from the corresponding iodo compounds (e.g. 210) (Scheme 85). ${ }^{219}$<smiles>CC(=O)NC1(C(C)=O)CCc2cc(I)c(I)cc2C1</smiles>

210

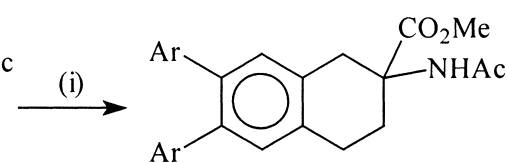

211
Scheme 85. (i) $\mathrm{ArB}(\mathrm{OH})_{2}, \mathrm{Pd}\left(\mathrm{PPh}_{3}\right)_{4}$, aq. $\mathrm{Na}_{2} \mathrm{CO}_{3}, \mathrm{THF} /$ toluene (1:1), $80^{\circ} \mathrm{C}$

Modification of Phe peptides was also reported following the SM cross-coupling reaction with 4-iodo-L-phenylalanine-based peptides. In this regard, various tri- and pentapeptides (e.g. 212) were prepared ${ }^{220}$ by the standard water-soluble carbodiimide-mediated peptide coupling strategy. SM cross-coupling of these peptides was performed<smiles>CC(=O)NC(N=[IH])C(NC(C)(C)C)C(C)=O</smiles>

$201 \mathrm{n}=1,2$<smiles>[R]C=CCC(NCCCCCCCC(C)(C)C)C(C)=O</smiles>

$202 \mathrm{R}=$ aryl, vinyl

Scheme 82.<smiles>NC1(C(=O)O)Cc2cc([Al])c(Br)cc2C1</smiles>

203

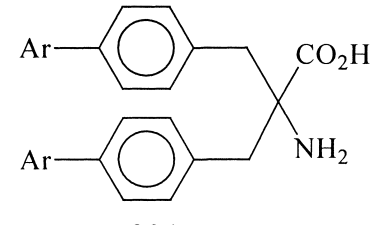

204<smiles>NC1(C(=O)O)CCc2cc([Al])c([Al])cc2C1</smiles>

205

Figure 15. Some constrained analogues of Phe.<smiles>Cc1cc(I)c(I)cc1I</smiles>

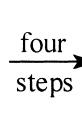<smiles>[AlH2]CC[AlH2]</smiles><smiles>CCOC(=O)NC1(C(=O)OCC)Cc2cc(C)c(I)cc2C1</smiles>

206<smiles>CCOC(=O)NC1(C(=O)OCC)Cc2cc([Al])c([Al])cc2C1</smiles>

207

Scheme 83. (i) $\mathrm{ArB}(\mathrm{OH})_{2}, \mathrm{Pd}\left(\mathrm{PPh}_{3}\right)_{4}$, aq. $\mathrm{Na}_{2} \mathrm{CO}_{3}$, THF/toluene $(1: 1), 80^{\circ} \mathrm{C}$.

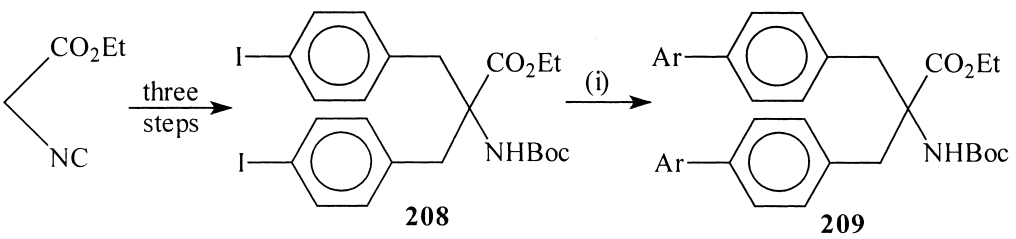

Scheme 84. (i) $\mathrm{ArB}(\mathrm{OH})_{2}, \mathrm{Pd}\left(\mathrm{PPh}_{3}\right)_{4}$, aq. $\mathrm{Na}_{2} \mathrm{CO}_{3}, \mathrm{THF} /$ toluene $(1: 1), 80^{\circ} \mathrm{C}$. 


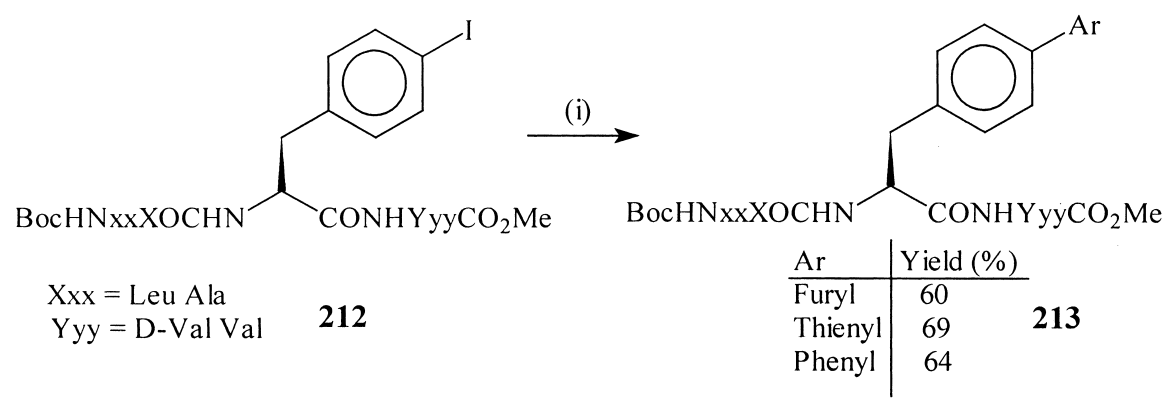

Scheme 86. (i) $\mathrm{ArB}(\mathrm{OH})_{2}, \mathrm{Pd}\left(\mathrm{PPh}_{3}\right)_{4}$, aq. $\mathrm{Na}_{2} \mathrm{CO}_{3}$, THF/toluene (1:1), $80^{\circ} \mathrm{C}$.

to generate the various modified analogues such as $\mathbf{2 1 3}$ (Scheme 86).

\section{SM Cross-coupling involving $\mathrm{sp}^{3}, \mathrm{sp}^{2}$ and $\mathrm{sp}$ hybridized compounds}

The Pd-catalysed SM cross-coupling reaction between various organoboron compounds $\left(\mathrm{sp}^{3}, \mathrm{sp}^{2}\right.$ and $\mathrm{sp}$ hybridised carbon-boron compounds) and various electrophiles in the presence of a suitable base has proved to be extremely useful for the formation of carbon-carbon bonds. An overview of the different types of coupling reactions will be discussed in this section.

\subsection{Coupling of $\mathrm{sp}^{2}$ hybridised $\mathrm{C}-\mathrm{B}$ compounds}

The stereo- and regioselective synthesis of conjugated alkadienes is of great importance in organic chemistry. Among the methods available for the preparation of conjugated dienes and polyenes using organometallic reagents, the SM cross-coupling reaction occupies an important position. The coupling reaction involves a low catalyst loading, high regio- and stereoselectivity and takes place while retaining the original configurations of the starting partners (i.e. alkenylboranes and haloalkenes).

Shen reported that a soft ligand such as tris(2-furyl)phos-<smiles>CC(=O)c1ccc(C=C(Br)C=CC(Br)=Cc2ccc(C(C)=O)cc2)cc1</smiles>

214

Scheme 87. (i) $\mathrm{Pd}_{2}(\mathrm{dba})_{3}(2.5 \%)$, TFP, aq. $\mathrm{Na}_{2} \mathrm{CO}_{3}$, dioxane.

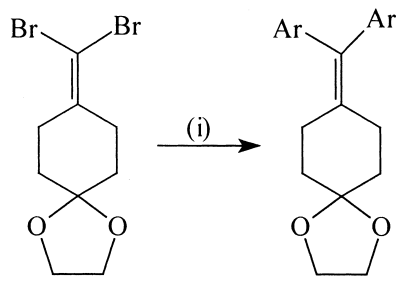

Scheme 88. (i) $\mathrm{ArB}(\mathrm{OH})_{2}, \mathrm{PdCl}_{2}\left(\mathrm{PPh}_{3}\right)_{2}, \mathrm{THF} / \mathrm{H}_{2} \mathrm{O}(4: 1), \mathrm{Na}_{2} \mathrm{CO}_{3}, 65^{\circ} \mathrm{C}$. phine (TFP) in combination with $\mathrm{Pd}_{2}(\mathrm{dba})_{3}$ is useful for preparing alkenes and 1,3-dienes such as 214 in a stereoselective manner (Scheme 87). ${ }^{221}$ Miller and coworkers have subsequently extended this methodology to the synthesis of tetrasubstituted alkenes utilising a tandem dibromo-olefination of ketone/SM arylation sequence (Scheme 88).222 Both cyclic and acyclic 1,1-dibromo-1alkenes participated in this protocol but, in general, the cyclo-olefins underwent reaction much faster than the acyclic derivatives. A high temperature is essential for the coupling of the acyclic dibromo-alkenes to obtain the coupling product in good yields.

Although TlOH has been used to accelerate the SM crosscoupling reaction at ambient temperature, ${ }^{223,224}$ problems associated with its stability and sensitivity promoted a search for alternatives. In this regard, Roush et al. have found that TlOEt is more stable and is a less expensive option (Scheme 89). ${ }^{225}$

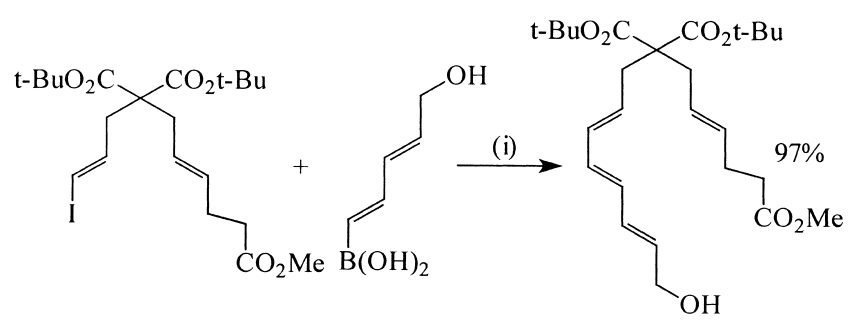

Scheme 89. (i) $\mathrm{Pd}\left(\mathrm{PPh}_{3}\right)_{4}(10 \%), \mathrm{TlOEt}, \mathrm{THF} / \mathrm{H}_{2} \mathrm{O}(3: 1)$.

Willis and Claverie have demonstrated that both mono- and di-triflates prepared under complementary conditions undergo a facile SM cross-coupling reaction. ${ }^{226}$ In this regard, six-membered mono-triflates gave good yields of the coupling product under mild reaction conditions, whereas the five-membered mono-triflates showed poor reactivity,

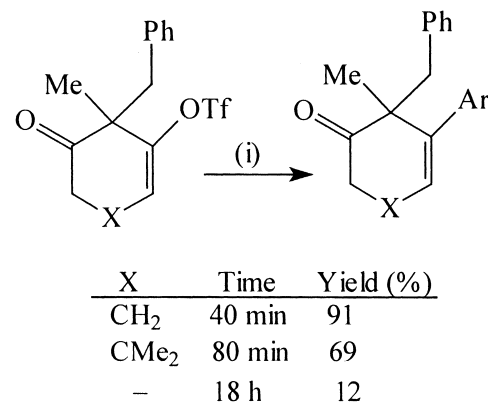

Scheme 90. (i) $\operatorname{ArB}(\mathrm{OH})_{2}(\mathrm{Ar}=p-\mathrm{MeO}-\mathrm{Ph}), \operatorname{Pd}(\mathrm{OAc})_{2}(10 \%), \mathrm{PPh}_{3}$, $\mathrm{THF} / \mathrm{H}_{2} \mathrm{O}, \mathrm{KOH}, \mathrm{RT}$. 


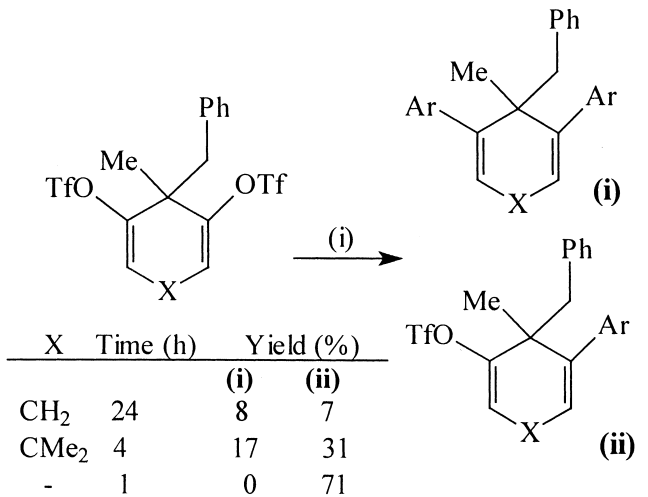

Scheme 91. (i) $\mathrm{ArB}(\mathrm{OH})_{2}(\mathrm{Ar}=p-\mathrm{MeO}-\mathrm{Ph}), \mathrm{Pd}(\mathrm{OAc})_{2}(10 \%), \mathrm{PPh}_{3}$, $\mathrm{THF} / \mathrm{H}_{2} \mathrm{O}, \mathrm{KOH}, \mathrm{RT}$.

even after prolonged reaction times (Scheme 90). The fivemembered di-triflates, however, underwent facile coupling to provide the mono-coupled product exclusively while the six-membered di-triflates reacted poorly under the reaction conditions shown in Scheme 91.

The feasibility of using benzyl bromides as SM coupling partners is relatively unknown. ${ }^{227}$ Chowdhury and Georghiou have shown that the cross-coupling reaction can be extended to achieve the coupling between phenyl-/ naphthylboronic acids such as $\mathbf{2 1 6}$ and benzyl bromides, iodides or bromomethylnaphthalenes 215 to give compounds of the type $\mathbf{2 1 7}$ in good yields (Scheme 92). ${ }^{228}$<smiles>COc1cc2ccccc2cc1CBr</smiles>
215<smiles>COc1cc2ccccc2cc1Br</smiles>
(i)<smiles>COc1cc2ccccc2cc1Cc1cc2ccccc2cc1OC</smiles>
216

Scheme 92. (i) $\mathrm{Pd}\left(\mathrm{PPh}_{3}\right)_{4}(10 \mathrm{~mol} \%)$, aq. $\mathrm{Na}_{2} \mathrm{CO}_{3}$, DME.

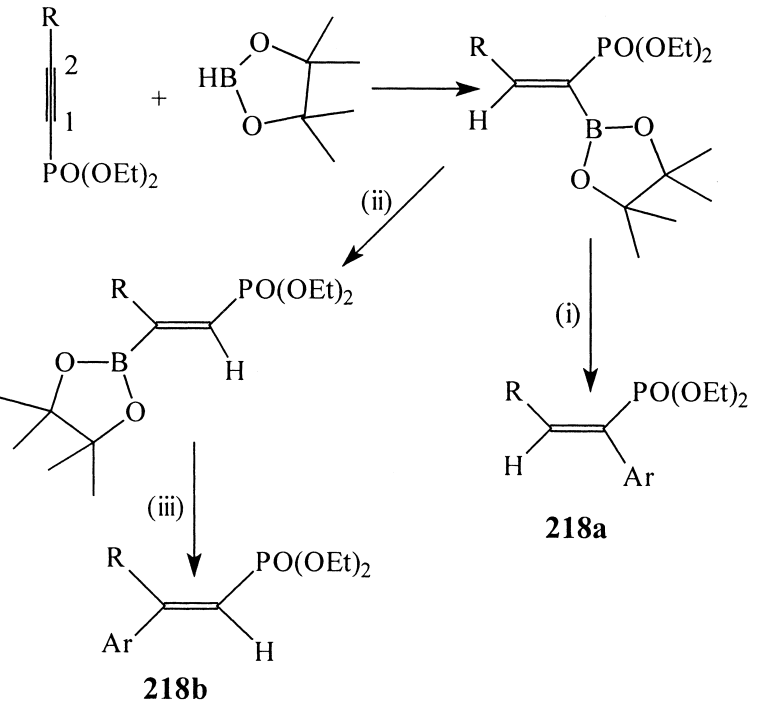

Scheme 93. (i) $\mathrm{ArI}, \mathrm{PdCl}_{2}\left(\mathrm{PPh}_{3}\right)_{2}$ (3\%), $\mathrm{NaOH}$, toluene, $1 \mathrm{~h}$ reflux. (ii) $\mathrm{PdCl}_{2}, \Delta$ (iii) $\mathrm{ArI}, \mathrm{PdCl}_{2}$ (30\%), $\mathrm{NaOH}$, toluene, $24 \mathrm{~h}$ reflux.
Pergament and Srebnik reported a regio- and stereospecific route to the trisubstituted vinyl phosphonates $\mathbf{2 1 8 a}$ and $\mathbf{2 1 8 b}$ using the SM cross-coupling reaction as a key step. ${ }^{229}$ Controlled hydroboration of 1-alkynylphosphates either under kinetic or thermodynamic conditions gave the $\mathrm{C}_{1^{-}}$ or $\mathrm{C}_{2}$-substituted vinyl phosphonates, respectively (Scheme 93). The SM cross-coupling of the hydroboration products with aryl iodides in the presence of $\mathrm{Pd}\left(\mathrm{PPh}_{3}\right)_{2} \mathrm{Cl}_{2}$ gave the corresponding vinyl phosphonates in good to moderate yield. This methodology has been extended to vinyl phosphonates. $^{230}$ The reaction is suitable for terminal alkenyl phosphonates, but internal alkenyl phosphonates gave a complex mixture of products.

Nan and Yang have described the Ni-catalysed crosscoupling reactions of the cyclohexenylphosphate $\mathbf{2 1 9}$ with a variety of arylboronic acids (Scheme 94) ${ }^{231}$ It is important to note that the same reaction was attempted with various other Pd catalysts and in most cases only a trace amount of the cross-coupling product was observed.

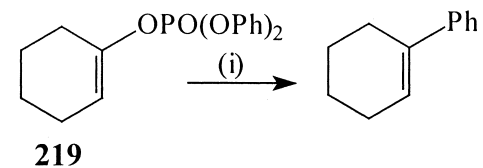

Scheme 94. (i) $\mathrm{PhB}(\mathrm{OH})_{2}, \mathrm{NiCl}_{2}$ (dppf), $n$ - $\mathrm{BuLi}, \mathrm{K}_{3} \mathrm{PO}_{4}$, toluene, $90^{\circ} \mathrm{C}$.

Organofluorine compounds have a wide range of applications as agrochemicals, pharmaceuticals and high performance materials. Chen, McCarthy and co-workers have shown that the Pd-catalysed cross-coupling of 1-fluorovinyl bromides with organoboranes provides a stereospecific route to 1-substituted-1-fluoro-olefins (Scheme 95). ${ }^{232 a}$ The coupling reaction of 1-fluoro-2-phenylvinyl chloride with phenylboronic acid under SM cross-coupling conditions gave the fluorinated olefin as a mixture of $E$ - and $Z$-isomers (1:1). Rolando and co-workers have synthesised fluorinated analogues of resveratrol and pterostilbene based on the Suzuki reaction between a bromofluoro-olefin and phenylboronic acid. ${ }^{232 b}$ In a related study, it was shown that, in limited cases, difluoroenol carbamate derivatives 220 could be coupled to a range of substrates under the SM coupling conditions (Scheme 96). ${ }^{233}$ (Z)-diiodoalkenes prepared from alkynes are found to be useful for stereodefined polyenes and highly functionalised tri- and tetrasubstituted alkenes under the SM cross-coupling conditions. $^{234}$
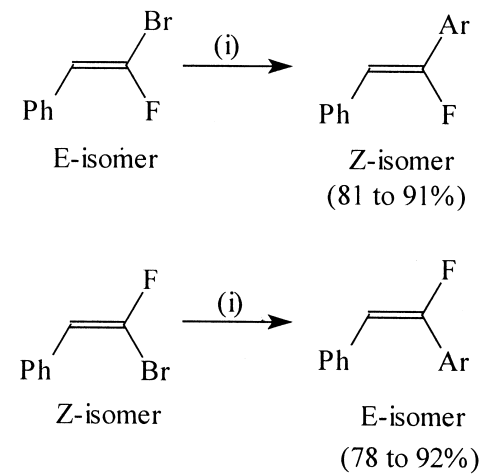

Scheme 95. (i) $\mathrm{ArB}(\mathrm{OH})_{2}, \mathrm{Pd}\left(\mathrm{PPh}_{3}\right)_{4}, \mathrm{Na}_{2} \mathrm{CO}_{3}, \mathrm{C}_{6} \mathrm{H}_{6} / \mathrm{EtOH} / \mathrm{H}_{2} \mathrm{O}$, reflux. 
<smiles>CCOC(=O)OC(I)=C(F)F</smiles>

220

Scheme 96. (i) $\mathrm{ArB}(\mathrm{OH})_{2}, \mathrm{Pd}\left(\mathrm{PPh}_{3}\right)_{2} \mathrm{Cl}_{2}(5 \%), \mathrm{K}_{3} \mathrm{PO}_{4}, \mathrm{DMF}, 100^{\circ} \mathrm{C}$.

The Pd-catalysed cross-coupling reaction of trifluoromethyl-containing bromovinyl ethers 221 with aryl- and alkenylboronic acids has been achieved stereoselectively to afford new tetrasubstituted enol ethers, e.g. 222 in excellent yield (Scheme 97). ${ }^{235}$ These enol ethers are useful precursors to tetrasubstituted olefins by a carbolithiation reaction.

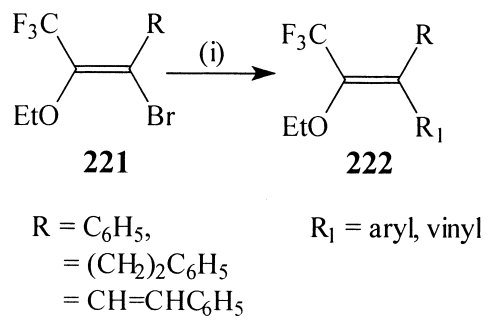

Scheme 97. (i) $\mathrm{R}_{1} \mathrm{~B}(\mathrm{OH})_{2}, \mathrm{Pd}\left(\mathrm{PPh}_{3}\right)_{4}, \mathrm{NaOH}, \mathrm{C}_{6} \mathrm{H}_{6}$.

$\alpha$-Trifluoromethylvinylmetallic compounds undergo facile defluorination and are therefore difficult to prepare. Jiang and co-workers have reported a convenient process for the preparation of $\alpha$-(trifluoromethyl)ethenylboronic acid $\mathbf{2 2 3}$ which, on Pd-catalysed cross-coupling with aryl halides, provided an efficient method for the synthesis of $\alpha$-trifluoromethylstyrene derivatives $\mathbf{2 2 4}$ under mild reaction conditions (Scheme 98). ${ }^{236}$ This reagent serves as a useful

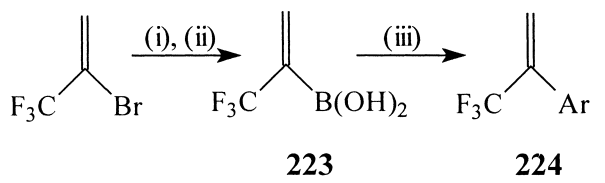

Scheme 98. (i) $\mathrm{Mg}, \mathrm{B}(\mathrm{OMe})_{3}$, THF, RT, 4 h. (ii) $\mathrm{H}_{3} \mathrm{O}^{+}$. (iii) $\mathrm{ArBr}$ or ArI, $\mathrm{Pd}\left(\mathrm{PPh}_{3}\right)_{4}(2 \%)$, aq. $\mathrm{Na}_{2} \mathrm{CO}_{3}$, toluene/MeOH, $70^{\circ} \mathrm{C}$.

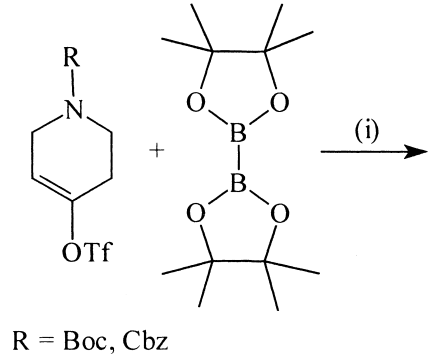

$\mathrm{R}=\mathrm{Boc}, \mathrm{Cbz}$

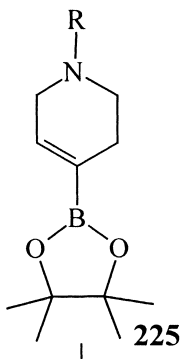

$\mathrm{X}=\mathrm{I}, \mathrm{Br}$,

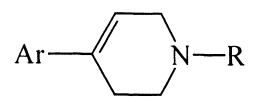

226 trifluoromethyl-containing building block for the synthesis of bioactive trifluoromethylated organic compounds.

The 4-aryltetrahydropyridine unit $\mathbf{2 2 6}$ represents an important synthetic target, because of its presence in a diverse array of biologically active entities and therapeutic agents. Eastwood has described a simple preparation of the cyclic vinyl boronates $\mathbf{2 2 5}$ derived from the vinyl triflate of the N-protected tetrahydropyridines (Scheme 99). SM crosscoupling of the starting boronate with aryl bromides, iodides and triflates proceeded in good yield to give the 4-aryl tetrahydropyridines $\mathbf{2 2 6}$. $^{237}$

Uenishi and Matsui have prepared geometrically pure alkenyl-substituted branched enynes by Sonogashira coupling followed by the SM-coupling reaction (Scheme 100). ${ }^{238}$

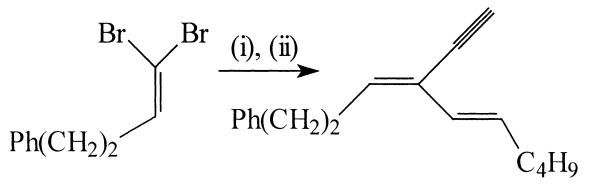

Scheme 100. (i) Sonogashira coupling. (ii) 1-Hexenylboronic acid, $\mathrm{PdCl}_{2}\left(\mathrm{PPh}_{3}\right)_{2}$, aq. $\mathrm{NaOH}$, THF, RT, $30 \mathrm{~min}$.

\subsection{Coupling of $\mathrm{sp}^{3}$ hybridised $\mathrm{C}-\mathrm{B}$ compounds}

The reaction of alkylborane derivatives prepared from alkenes via a hydroboration reaction is useful in organic synthesis. One of the primary alkyl groups in the trialkylborane participates in the coupling reaction and the reaction with the secondary alkyl group is very slow. Hydroboration reagents used for the terminal alkenes are 9-BBN, diisoamylborane, and dicyclohexylborane, 9-BBN being mostly used due to its ease of handling, high selectivity of hydroboration and high reactivity in the cross-coupling reaction.

There are very few examples of Pd-catalysed cross-coupling reactions of allylboron derivatives. ${ }^{239,240}$ In this regard, Fürstner and Seidel have developed a general procedure for the transfer of the allyl group from 9-allyl-9-BBN 227 to aryl halides and triflates under the SM coupling conditions (Scheme 101). ${ }^{241}$ The highly sensitive B-allyl-9-BBN can be handled as borate complex by the addition of KOMe for extended periods. The reaction can tolerate a wide range of functional groups except aldehydes.

Lera and co-workers have successfully demonstrated a useful method for synthesising the alkylpyridine $\mathbf{2 2 8}$ by a

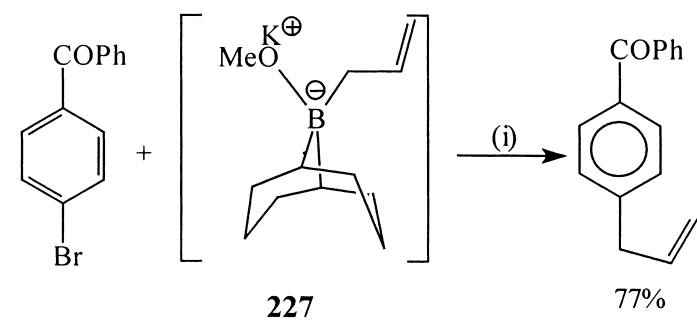

Scheme 101. (i) $\mathrm{PdCl}_{2}$ (dppf) (3 mol\%), THF, reflux 


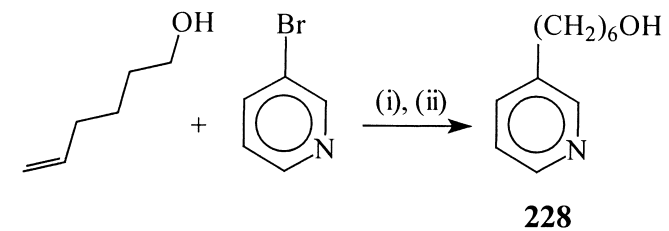

Scheme 102. (i) 9-BBN, THF. (ii) $\mathrm{Pd}\left(\mathrm{PPh}_{3}\right)_{4}, \mathrm{~K}_{2} \mathrm{CO}_{3}, \mathrm{H}_{2} \mathrm{O}, \mathrm{DMF}, 65^{\circ} \mathrm{C}$.

Pd-catalysed cross-coupling reaction of B-alkyl-9-BBN derivatives and the bromopyridines (Scheme 102). ${ }^{242}$ The reaction can tolerate a variety of functional groups in the reaction partners and therefore provides a convenient choice for the preparation of biologically active and pharmaceutically pertinent alkyl pyridines.

Kamatani and Overman have reported a one-pot, RT, SM cross-coupling method using a $\mathrm{PdCl}_{2}$ (dppf) catalyst for introducing a protected $\beta$-aminoethyl group into arenes and alkenes, resulting in a convenient synthesis of phenethyl and homoallylic amines (Scheme 103). ${ }^{243}$

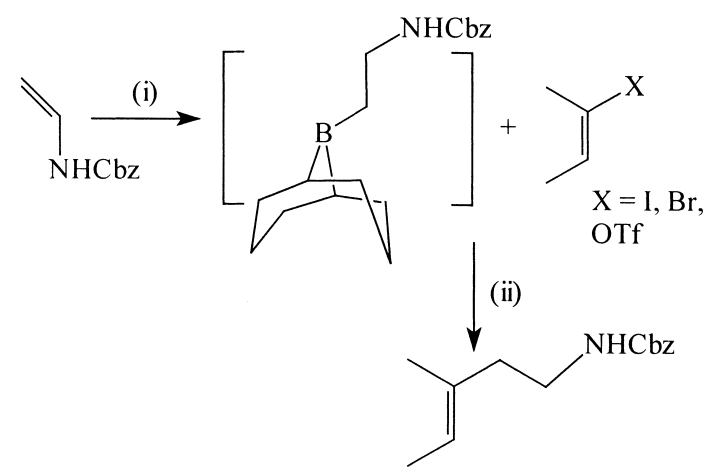

Scheme 103. (i) $(9-\mathrm{BBN})_{2}, \mathrm{THF},-10^{\circ} \mathrm{C}$ to RT. (ii) $\mathrm{PdCl}_{2}(\mathrm{dppf}) \cdot \mathrm{CH}_{2} \mathrm{Cl}_{2}$, $3 \mathrm{~N} \mathrm{NaOH}, \mathrm{RT}$.

Danheiser and co-workers have reported a new strategy for the synthesis of substituted azulenes (Scheme 104). ${ }^{244}$ The best results were obtained by employing the compound $\mathbf{2 2 9}$ in the SM cross-coupling reaction with B-alkyl- or B-aryl-9$\mathrm{BBN}$ to afford the 1-alkyl- and 1-arylazulenes 230 by using Buchwald's $o$-(dicyclohexylphosphino)biphenyl ligand. This methodology was extended to the efficient synthesis of the anti-ulcer drug, egualen sodium (KT1-32) 231.

Lapinsky and Bergmeier have utilised the SM crosscoupling reaction for the preparation of the substituted aziridines $\mathbf{2 3 3}$ that are difficult to prepare by other methods. $^{245}$ The olefin $\mathbf{2 3 2}$ was treated with 9-BBN

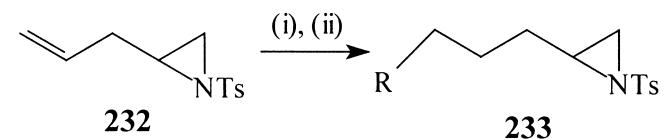

Scheme 105. (i) 9-BBN, THF, RT. (ii) RX (vinyl or aryl halide), $\mathrm{K}_{3} \mathrm{PO}_{4}$, $\mathrm{PdCl}_{2}$ (dppf), $\mathrm{CH}_{2} \mathrm{Cl}_{2}$, DMF, RT.

followed by reaction with the appropriate vinyl or aryl bromide (iodide) to give the desired aziridines (Scheme 105).

The stereodefined synthesis of the cyclopropane moiety in an optically active form has enormous synthetic potential in natural product synthesis because the cyclopropane unit is present as a structural element in many natural products of biological importance. Several methods were applied to prepare aryl-substituted cyclopropanes by the SM type reaction. The coupling of arylboronic acids with iodocyclopropane was reported by Charette. ${ }^{246}$ In this regard, cyclopropyl boronates have been shown to be competent nucleophilic partners for the SM cross-coupling reaction with aryl bromides and iodides leading to the transdisubstituted cyclopropanes. ${ }^{247}$ Deng and co-workers have subsequently developed a new method for the arylsubstituted cyclopropanes. ${ }^{248}$ Aryl halides (triflates) have been shown to undergo the SM cross-coupling reaction with trans-cyclopropylboronic acids to give the pure transcyclopropylarenes, e.g. 234 in good to excellent yields in the presence of the appropriate base and $\mathrm{NaBr}$ (Scheme 106). Addition of 1 equiv. of $\mathrm{NaBr}$ avoided the premature decomposition of the Pd catalyst and substantially improved the yields of the cross-coupling products. The same workers have used cyclopropylboronic acids for the preparation of the stereodefined cyclopropyl-substituted $\alpha, \beta$-unsaturated ester $\mathbf{2 3 5},{ }^{249}$ cyclopropyl-substituted heteroarenes such as $\mathbf{2 3 6}^{250}$ and for the SM cross-coupling reaction of cyclopropylboronic esters with benzyl bromides (Scheme 107). ${ }^{251}$ Optically active cyclopropylboronate esters can also undergo the SM cross-coupling reaction with benzyl bromides to give the corresponding optically active benzylsubstituted cyclopropanes such as $\mathbf{2 3 7}$.

The methodology was extended to the coupling of aryl bromides or triflates with the optically active cyclopropylboronic

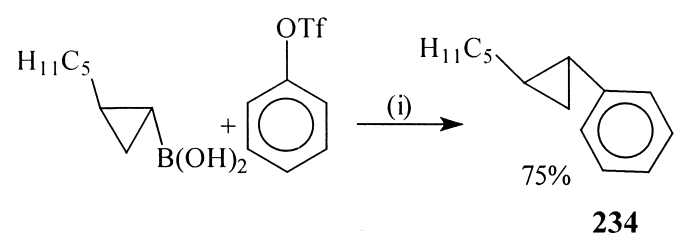

Scheme 106. (i) $\mathrm{Pd}\left(\mathrm{PPh}_{3}\right)_{4}, \mathrm{KF} \cdot 2 \mathrm{H}_{2} \mathrm{O}, \mathrm{NaBr}$, toluene.

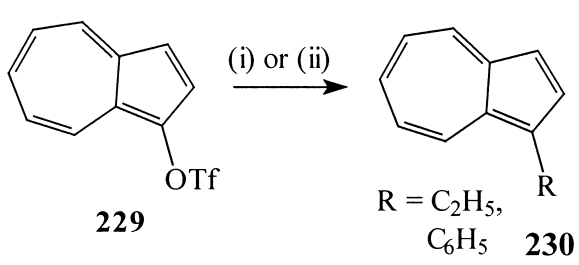

230

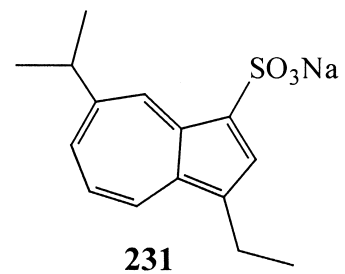

231

Scheme 104. (i) B-ethyl-9-BBN, $\mathrm{Pd}(\mathrm{OAc})_{2}$, (o-biphenyl) $\mathrm{PCy}_{2}, \mathrm{Cs}_{2} \mathrm{CO}_{3}$, THF, RT. (ii) B-Ph-9-BBN, $\mathrm{Pd}(\mathrm{OAc})_{2}$, (o-biphenyl)PCy $\mathrm{PC}_{2}, \mathrm{Cs}_{2} \mathrm{CO}_{3}$, THF, reflux. 
<smiles>CC(=O)/C(C)=C/Br</smiles>

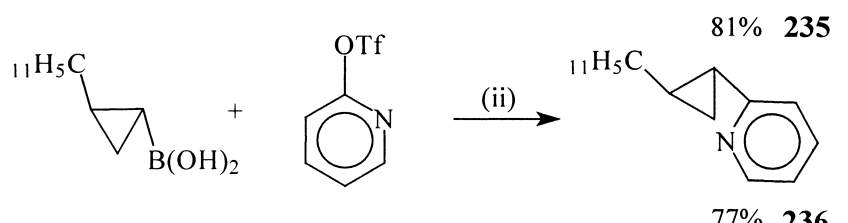

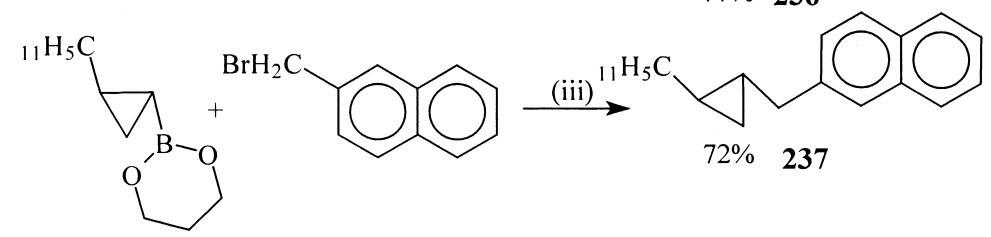

Scheme 107. (i) $\mathrm{Pd}\left(\mathrm{PPh}_{3}\right)_{4}, \mathrm{~K}_{3} \mathrm{PO}_{4} \cdot 3 \mathrm{H}_{2} \mathrm{O}$, toluene, $100^{\circ} \mathrm{C}$. (ii) $\mathrm{Pd}\left(\mathrm{PPh}_{3}\right)_{4}, \mathrm{KF} \cdot 2 \mathrm{H}_{2} \mathrm{O}, \mathrm{NaBr}$, toluene, $100^{\circ} \mathrm{C}$. (iii) $\mathrm{PdCl}_{2}(\mathrm{dppf}$ ), $\mathrm{KOH}, \mathrm{Ag} 2 \mathrm{O}$, THF, reflux.

acids 238a and $\mathbf{2 3 8 b}$, easily obtained in good yields and with excellent ee $(\leq 94 \%)$ by the asymmetric cyclopropanation of the alkenyl boronates with the optically pure $N, N, N^{\prime}, N^{\prime}$-tetramethyltartaric acid diamide (TMTA) chiral auxiliary (Scheme 108).247,252,253 During the coupling reaction, the absolute configuration of the cyclopropyl group was retained.

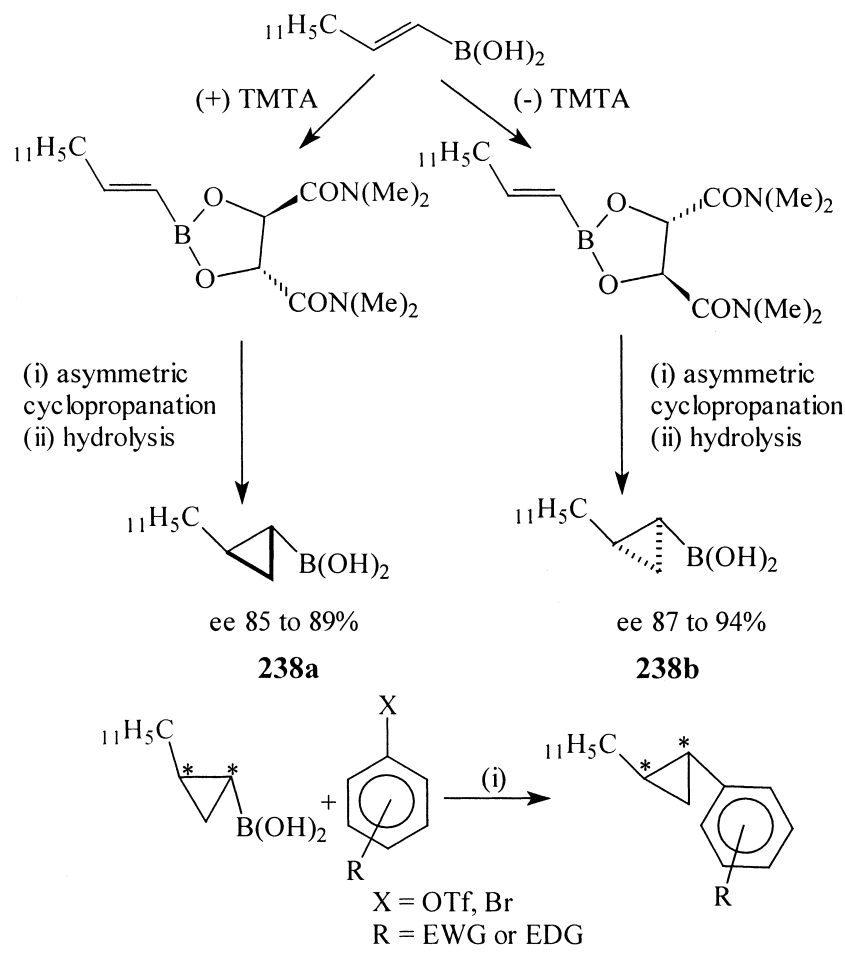

Scheme 108. (i) $\mathrm{Pd}\left(\mathrm{PPh}_{3}\right)_{4}, \mathrm{KF} \cdot 2 \mathrm{H}_{2} \mathrm{O}$ or $\mathrm{K}_{3} \mathrm{PO}_{4} \cdot 3 \mathrm{H}_{2} \mathrm{O}$, toluene, $100^{\circ} \mathrm{C}$.

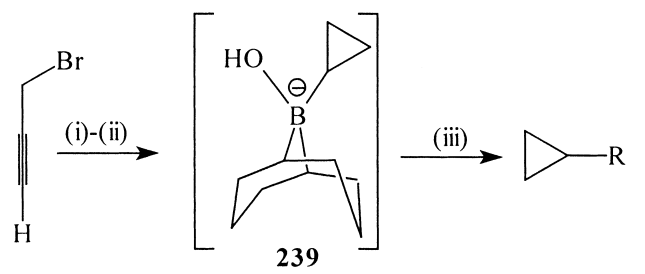

Scheme 109. (i) $(9-\mathrm{BBN})_{2}$, THF. (ii) $\mathrm{NaOH}$. (iii) $\mathrm{RBr}, \mathrm{Pd}\left(\mathrm{PPh}_{3}\right)_{4}, \mathrm{R}=$ aryl or vinyl.
Soderquist et al. have reported the hydroxy(cyclopropyl)-9BBN complex 239, which undergoes an efficient crosscoupling reaction under mild conditions to produce a variety of aryl- and vinylcyclopropanes in good to excellent yield (Scheme 109). ${ }^{254}$

In general, the participation of $n$-alkylboronic acid esters in the SM cross-couplin $g$ reaction is rare and the yields of the reaction are normally low. Recently, Molander and Ito have illustrated the cross-coupling of potassium $n$-alkyltrifluoroborates with aryl and alkenyl triflates. ${ }^{255}$ Following this work, Falck and Zou have reported the Pd-catalysed crosscoupling of lithium $n$-alkylborates (generated in situ via the addition of sec-butyl-lithium to the boronate ester) with variety of electrophiles in moderate to good yields (Scheme 110). ${ }^{256}$

The uses of methylboron derivatives or methylboronic acids are limited in the literature as they are expensive and not readily available. Methylboranes derived from 9-BBN are very reactive but are less readily available. Gray and

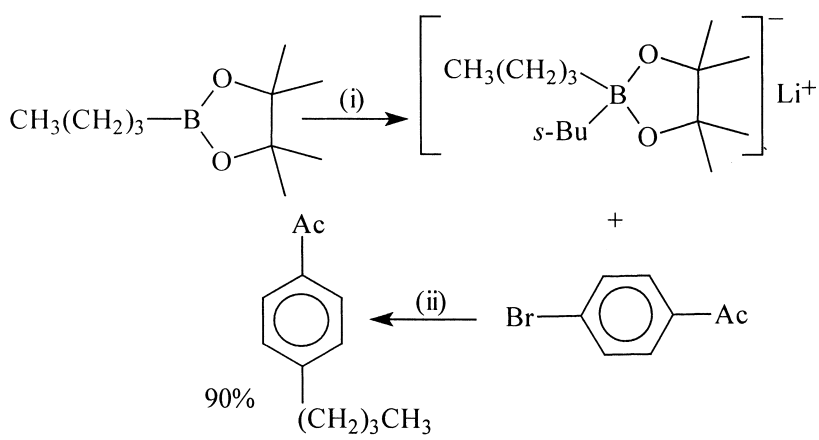

Scheme 110. (i) sec-BuLi, THF. (ii) $\mathrm{PdCl}_{2}$ (dppf), $\mathrm{NaOAc}$, reflux.

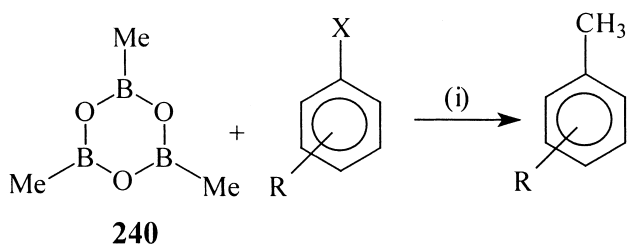

Scheme 111. (i) $\mathrm{Pd}\left(\mathrm{PPh}_{3}\right)_{4}(10 \mathrm{~mol} \%), \mathrm{K}_{2} \mathrm{CO}_{3}$, dioxane, reflux. 
co-workers have used a simple methylboron derivative, trimethylboroxine 240, for the SM cross-coupling of aryl halides $(\mathrm{X}=\mathrm{Cl}, \mathrm{Br}, \mathrm{I})$ under $\mathrm{Pd}$-catalysed conditions (Scheme 111). ${ }^{257}$ In connection with the synthesis of 3-aminopyridine-2-carboxaldehyde thiosemicarbazone, the SM coupling reaction has been utilised to introduce a methyl group into the pyridine nucleus using methylboronic acid and a $\operatorname{Pd}(0)$ catalyst (Scheme 112). ${ }^{258} \mathrm{Fu}$ and

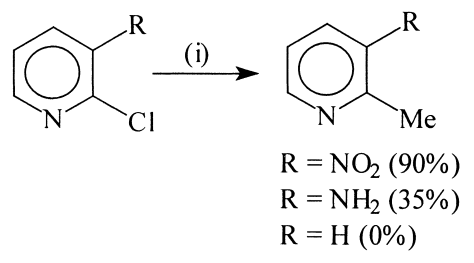

Scheme 112. (i) $\mathrm{MeB}(\mathrm{OH})_{2}, \mathrm{Pd}\left(\mathrm{PPh}_{3}\right)_{4}, \mathrm{~K}_{2} \mathrm{CO}_{3}$, dioxane, $\Delta$.

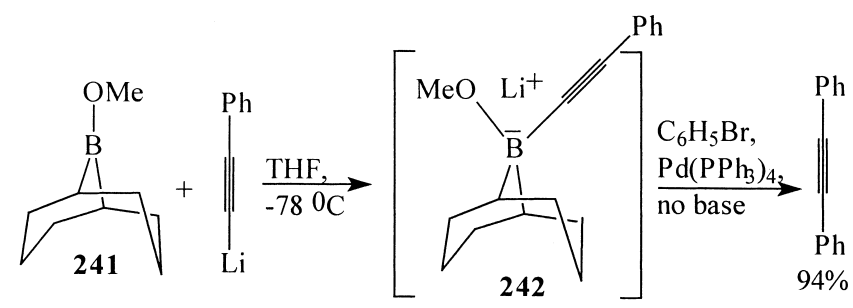

Scheme 113.

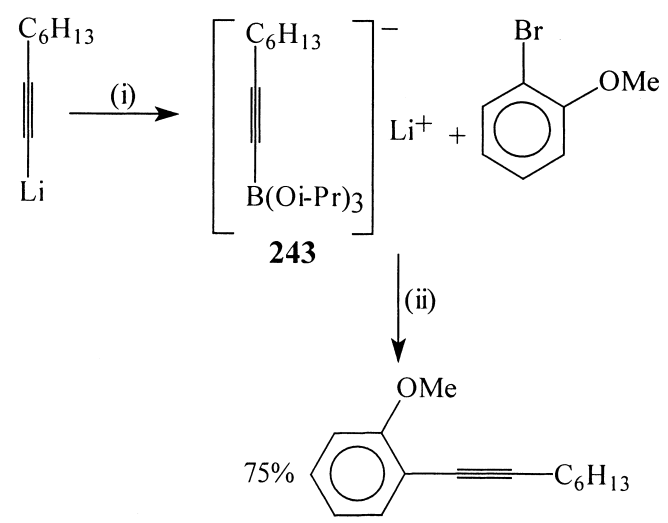

Scheme 114. (i) $\mathrm{B}(\mathrm{O} i-\mathrm{Pr})_{3}, \mathrm{DME},-78^{\circ} \mathrm{C}$. (ii) $\mathrm{Pd}\left(\mathrm{PPh}_{3}\right)_{4}(3 \mathrm{~mol} \%)$, $\mathrm{F}^{-}$(2 eq), THF/DME, reflux. co-workers reported a simple method for the synthesis of long-chain alkanes involving the alkyl-alkyl SM crosscoupling reaction of alkyl 9-BBN derivatives with alkyl halides under room temperature and $\mathrm{Pd}(\mathrm{OAc})_{2}$ catalysis conditions. $^{259}$

\subsection{Coupling of sp hybridised C-B compounds}

Alkynylboronic derivatives are rarely used in the SM crosscoupling reaction although alkynylboranes are known to be useful synthetic intermediates. Compared to other organoboranes, alkynylboronic esters are stronger Lewis acids and are easily hydrolysed. Because of this property alkynylboron compounds are not used in the SM cross-coupling reaction. To overcome this difficulty, Soderquist and co-workers have found that the addition of B-OMe-9BBN 241 to alkynyl-lithium reagents gave the stable methoxy(alkynyl)borate complexes (e.g. 242) which undergo the SM cross-coupling efficiently to produce various alkynyl derivatives (Scheme 113). ${ }^{260}$ At approximately the same time, Fürstner and Seidel reported a similar type of SM cross-coupling reaction. ${ }^{261}$

Colobert and co-workers later demonstrated the SM crosscoupling reaction to be an alternative to the Sonogashira coupling between the alkynylboronic ester 243 and aryl halides in quantitative yields (Scheme 114). ${ }^{262}$ The reaction was carried out in one pot without the isolation of the active ate-complex $\mathbf{2 4 3}$, which was very sensitive to atmospheric oxygen. A solution of tetrabutylammonium fluoride (1 M in THF) was found to be the best fluoride source. In this reaction, the use of the base was not necessary and various aryl and vinyl bromides underwent a coupling reaction under the reaction conditions to produce a variety of alkynyl derivatives.

\section{Synthesis of natural and unnatural products}

The application of the SM coupling reaction is growing rapidly in natural products synthesis and in this section we will discuss its recent (1999-2001) applications to the synthesis of natural products, non-natural products, and other bioactive compounds.

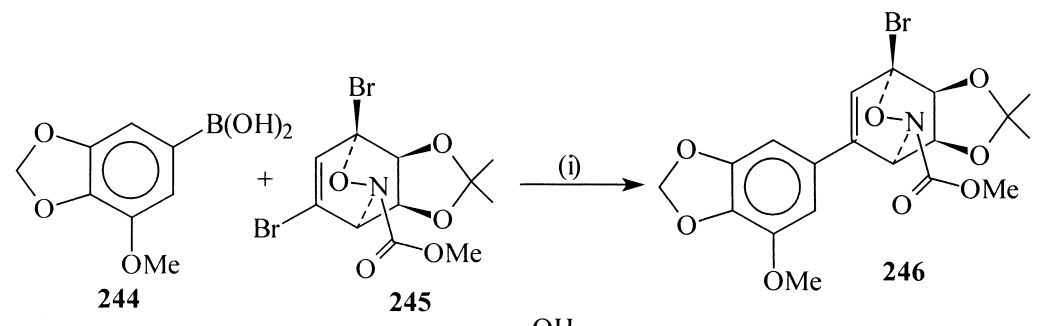<smiles>O=C1NC2C(=CC(O)C(O)C2O)c2cc3c(c(O)c21)OCO3</smiles> 


\subsection{Reactions involving alkyl- and arylboronic acids}

In 1999, Hudlicky and his co-workers have reported the synthesis of an antitumour alkaloid, narciclasin 247 , by using a Pd-catalysed SM cross-coupling reaction of the dibromo derivative $\mathbf{2 4 5}$ with the boronic acid $\mathbf{2 4 4}$ to give the key intermediate 246, followed by a sequential transformation with $20 \%$ overall yield and with $30 \%$ yield of the coupling step (Scheme 115). ${ }^{263}$

The compounds 251 and 252 act as endothelin (ET-1) receptor antagonists and are useful drug molecules for treating hypertension and other cardiovascular diseases. Pridgen et al. reported the $\mathrm{PdCl}_{2}(\mathrm{dppf})$-catalysed SM cross-coupling reaction of the chiral enol ethers 248 with the boronic acids $\mathbf{2 4 9}$ to furnish the indene derivatives $\mathbf{2 5 0}$ in $90 \%$ ee which can be transformed into $\mathbf{2 5 1}$ and 252 by further functional group transformations (Scheme 116). ${ }^{264}$

A key biaryl system $\mathbf{2 5 5}$ for protease inhibitors such as $\mathbf{2 5 6}$ and $\mathbf{2 5 7}$ was prepared by $\mathrm{Ma}$ and $\mathrm{Wu}$ from a ligandless $\mathrm{Pd}(\mathrm{OAc})_{2}$-catalysed SM coupling reaction of 7-iodoisatin 253 with the sterically hindered arylboronic acid $\mathbf{2 5 4}$. They found up to $70 \%$ yield when KF was used as the base and methanol as the solvent (Scheme 117). ${ }^{265}$

Kozikowski et al. synthesised the spiro analogues of cocaine 261a and 261b, to decrease the potency and capacity for abuse, involving the SM coupling reaction of the enol<smiles>COC(=O)C1=C(O)CC2CCC1N2C</smiles><smiles>Oc1ccccc1CCO[SnH2]</smiles><smiles>CC(=O)C1=C(c2ccccc2CCO[SbH2])CC2CCC1N2C</smiles>

TBDPS $=t$-butyldiphenylsilyl

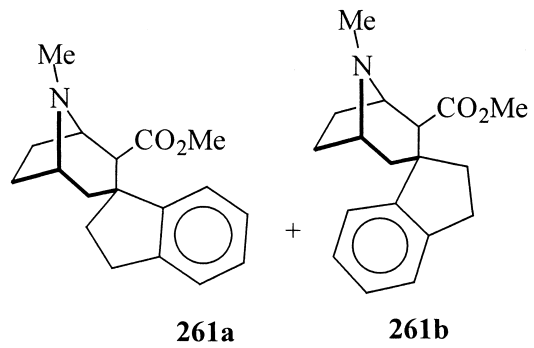

Scheme 118. (i) $\mathrm{Pd}_{2}(\mathrm{dba})_{3}, \mathrm{LiBr}$, aq. $\mathrm{Na}_{2} \mathrm{CO}_{3}$, diethoxymethane, reflux, $72 \%$.

triflate $\mathbf{2 5 8}$ and the boronic acid derivative $\mathbf{2 5 9}$ to give $\mathbf{2 6 0}$. Radical cyclisation or intramolecular Michael addition of 260 gave 261a and 261b (Scheme 118). ${ }^{266}$

Huffman and co-workers have introduced various aryl<smiles>[R20]OC1=C(C(=O)[O-])c2cc(Oc3ccc4c(c3)OCO4)ccc2C1c1ccc2c(c1)OCO2</smiles>

Scheme 116. (i) $\mathrm{PdCl}_{2}$ (dppf) (5 mol\%), aq. $\mathrm{K}_{2} \mathrm{CO}_{3}$, toluene/acetone/water, $70^{\circ} \mathrm{C}, 50-98 \%$.

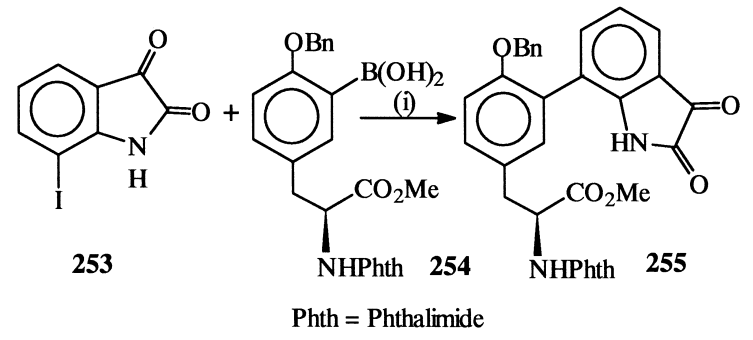

Phth $=$ Phthalimide

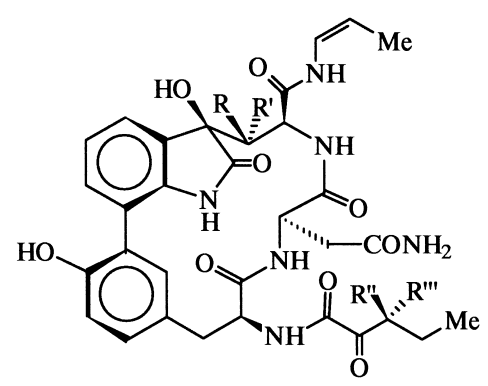

$256 \mathrm{R}=\mathrm{OH} ; \mathrm{R}^{\prime}=\mathrm{H} ; \mathrm{R}^{\prime \prime}=\mathrm{Me} ; \mathrm{R}^{\prime \prime \prime}=\mathrm{H}$ $257 \mathrm{R}=\mathrm{OH} ; \mathrm{R}^{\prime}=\mathrm{H} ; \mathrm{R}^{\prime \prime}=\mathrm{H} ; \mathrm{R}^{\prime \prime \prime}=\mathrm{Me}$

Scheme 117. (i) $\mathrm{Pd}(\mathrm{OAc})_{2}(3 \mathrm{~mol} \%), \mathrm{KF}, \mathrm{MeOH}, 20^{\circ} \mathrm{C}, 72 \mathrm{~h}, 64 \%$. 


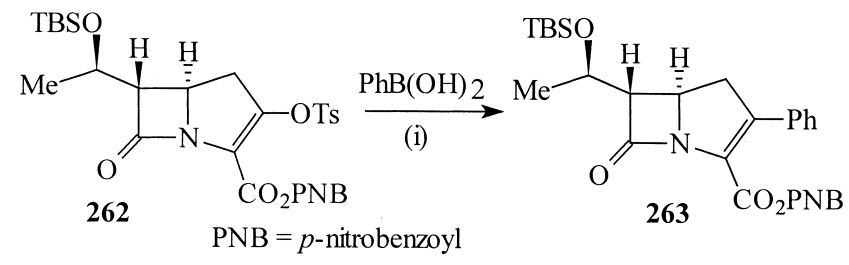

Scheme 119. (i) $\mathrm{PdCl}_{2}$ (dppf), aq. $\mathrm{K}_{2} \mathrm{CO}_{3}, \mathrm{Bu}_{4} \mathrm{~N}^{+} \mathrm{Cl}^{-} / \mathrm{THF}, 30^{\circ} \mathrm{C}, 67 \%$.

groups at the 2-position of $\beta$-lactam antibiotics (e.g. 263) by using the readily available vinyl tosylate $\mathbf{2 6 2}$ and boronic acids instead of the expensive triflate under phase transfer catalyst conditions (Scheme 119). ${ }^{267}$

Taylor et al. reported a simple method for the preparation of aryl-substituted $O$-methyl oxime enamides such as 266 which are present in several antitumour natural products. They used a complementary combination of coupling partner alkyl halides, e.g. 264 and boronic acids e.g. 265 to generate the $O$-methyl oxime enamide moiety (Scheme 120). ${ }^{268}$

The biologically important ethanolamines 267 were synthesised by Organ and co-workers via a $\mathrm{Pd}\left(\mathrm{PPh}_{3}\right)_{4}$-catalysed reaction of bromo-olefins with arylboronic acids followed by other functional group transformations, as shown in Scheme 121. ${ }^{269}$
The preparation of epoxyicosatrienoic acids (EETs) is of immense interest because of their physiological properties. Recently, Falck and co-workers reported a stereospecific synthesis of these compounds (270a and 270b) by using a $\mathrm{PdCl}_{2}$ (dppf)-catalysed SM cross-coupling reaction of the chiral epoxyvinyl iodides $268 \mathrm{a}$ and $\mathbf{2 6 8 b}$ and the corresponding alkane boronic acids 269a and 269b (Scheme 122). ${ }^{270}$

The reaction of 7-iodoisatin $\mathbf{2 5 3}$ with aryl- and heteroarylboronic acids gave the aryl-substituted isatins which on oxidative hydrolysis offered the industrially important arylsubstituted anthranilic acids $\mathbf{2 7 1}$ as depicted in Scheme $123 .{ }^{271}$

Incorporation of substituted prolines into peptides restricts the conformational freedom of the peptide. In this connection, Kamenecka et al. have developed an enantioselective

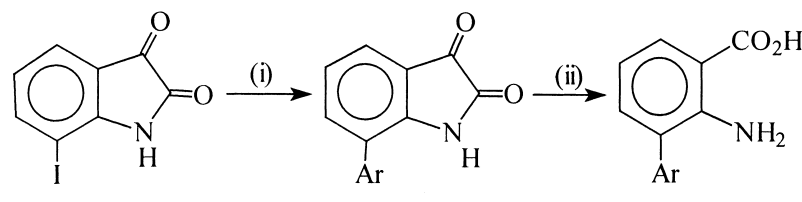

253

Scheme 123. (i) $\mathrm{ArB}(\mathrm{OH})_{2}, \mathrm{Pd}\left(\mathrm{PPh}_{3}\right)_{4}$, aq. $\mathrm{NaHCO}_{3}, \mathrm{DME} / \mathrm{H}_{2} \mathrm{O}$. (ii) $\mathrm{NaOH}, \mathrm{H}_{2} \mathrm{O}_{2}, 55-70 \%$.

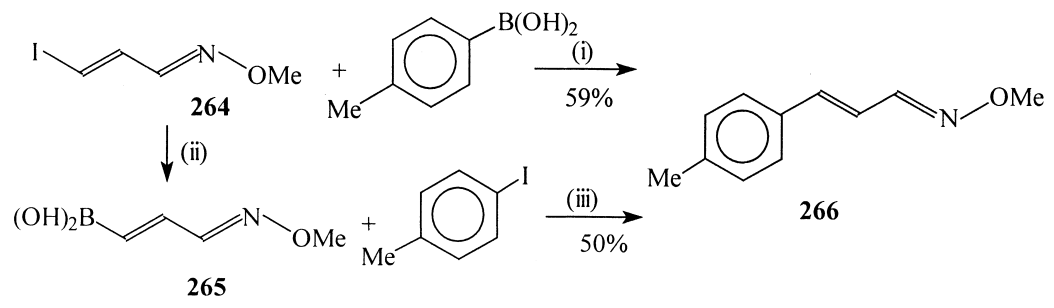

Scheme 120. (i) $\mathrm{Pd}\left(\mathrm{PPh}_{3}\right)_{4}$, aq. $\mathrm{K}_{2} \mathrm{CO}_{3}$, dioxane. (ii) $\mathrm{B}\left(\mathrm{OPr}^{i}\right)_{3}$. (iii) $\mathrm{PdCl}_{2}$ (dppf), dioxane, $\mathrm{KOH}$.

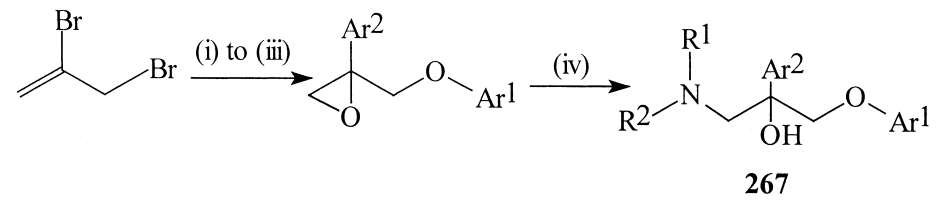

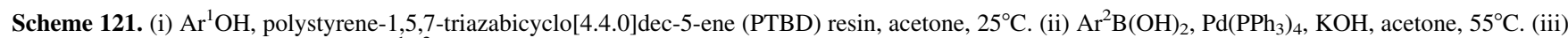
oxone, $\mathrm{NaHCO}_{3}$, acetone, $\mathrm{H}_{2} \mathrm{O}$. (iv) $\mathrm{R}^{1} \mathrm{R}^{2} \mathrm{NH}, \mathrm{CH}_{3} \mathrm{COCH}_{2} \mathrm{OH}, 80^{\circ} \mathrm{C}$.
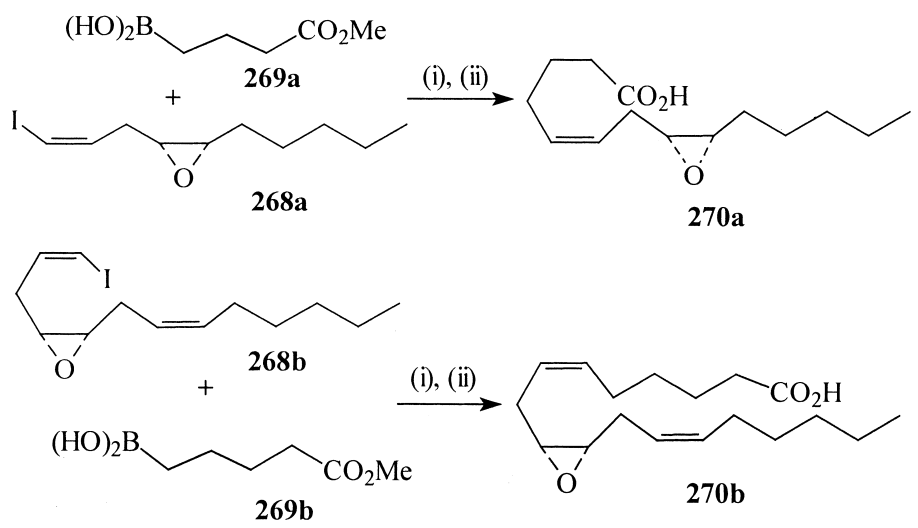

Scheme 122. (i) $\mathrm{PdCl}_{2}$ (dppf) (10 mol\%), $\mathrm{Ag}_{2} \mathrm{O}$ (2.4 equiv.), $\mathrm{K}_{2} \mathrm{CO}_{3}$, THF, $80^{\circ} \mathrm{C}, 8$ h. (ii) LiOH, THF- $\mathrm{H}_{2} \mathrm{O}, \mathrm{RT}, 12 \mathrm{~h}, 93 \%$. 


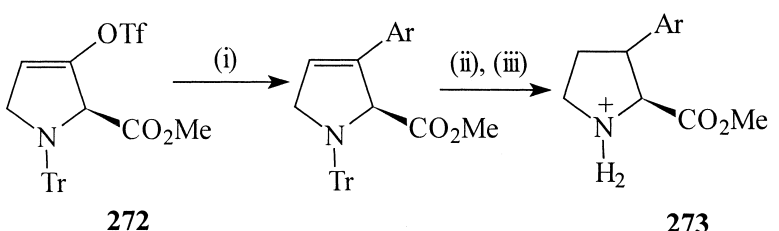

Scheme 124. (i) $\mathrm{ArB}(\mathrm{OH})_{2}, \mathrm{PdCl}_{2}$ (dppf) $(5 \mathrm{~mol} \%), \mathrm{K}_{2} \mathrm{CO}_{3}, \mathrm{MeOH} /$ toluene, $85^{\circ} \mathrm{C}, 9$ h. (ii) $\mathrm{HCl}, \mathrm{MeOH}, \mathrm{CH}_{2} \mathrm{Cl}_{2}$. (iii) $\mathrm{H}_{2} / \mathrm{Pd}-\mathrm{C}, \mathrm{MeOH}$.

convergent approach to 3-aryl-substituted prolines 273 mediated by the $\mathrm{PdCl}_{2}(\mathrm{dppf})$-catalysed SM cross-coupling reaction of the triflate $\mathbf{2 7 2}$ with boronic acids followed by a hydrolysis and hydrogenation sequence as shown in Scheme $124 .^{272}$<smiles>C/C=C/C1O[C@H](C(O)/C=C/C=C(/CC)[C@@H](C)C/C(C)=C\C=C\C2CC=CC(=O)O2)C[C@H](O)[C@H]1C</smiles>

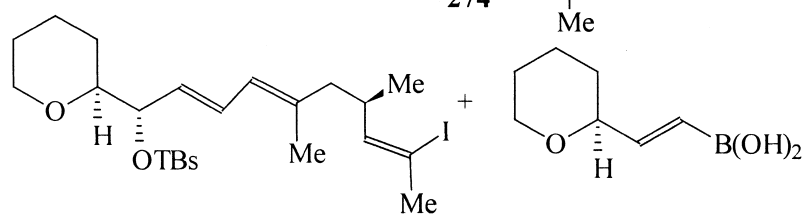

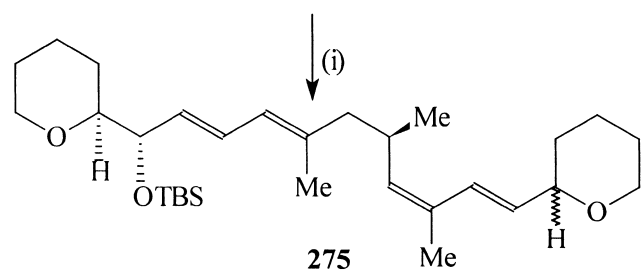

Scheme 125. (i) $\mathrm{Pd}\left(\mathrm{PPh}_{3}\right)_{4}, \mathrm{THF}, \mathrm{NaOH}, \mathrm{H}_{2} \mathrm{O}$, reflux, 3 h, $59 \%$.
Kalesse et al. prepared the polyene fragment $\mathbf{2 7 5}$ of ratjadone $\mathbf{2 7 4}$, a cytotoxic metabolite which belongs to the polyketide family and which can inhibit the function of the crml gene, by using the Pd-catalysed Heck and SM cross-coupling reactions as the key steps (Scheme 125). ${ }^{273}$

Brückner and co-workers synthesised the butenolide moiety 279 of peridinin 280 by the $\mathrm{Pd}\left(\mathrm{PPh}_{3}\right)_{4}$-catalysed sequential stereo- and regiocontrolled reactions of the corresponding boronic acids 277 and $\mathbf{2 7 8}$ and the trihalo compound $\mathbf{2 7 6}$ followed by further functional group transformations (Scheme 126). ${ }^{274}$

The SM cross-coupling reaction of 1-bromo- $N$-[(propylamino)carbonyl]benzene-2-sulfonamide $\mathbf{2 8 1}$ with 4-formylbenzeneboronic acid gave a key intermediate, the biphenyl$4^{\prime}$-carbaldehyde $\mathbf{2 8 2}$, which on reductive amination gave HR-720 283, a promising orally active non-tetrazole angiotensin II receptor antagonist (Scheme 127). ${ }^{275}$

Yoon and co-workers reported the synthesis of the arylsubstututed spiropyrans $\mathbf{2 8 5}$, which show liquid crystalline and non-linear optical properties, by the $\mathrm{Pd}(\mathrm{OAc})_{2}$-catalysed SM cross-coupling reaction of the iodospiropyran 284 with arylboronic acids in good yields (Scheme 128). ${ }^{276}$

In 1998, Geen et al. developed a versatile method for the synthesis of the aromatic benzo[c]phenanthredine alkaloid 289 by using the SM cross-coupling of 2-bromo-1formamidonaphthalenes $\mathbf{2 8 7}$ with the corresponding boronic acid $\mathbf{2 8 6}$ followed by ring closure based on the Bischler-Napieralski reaction via 288 (Scheme 129). ${ }^{277}$

Diazonamide A and B are structurally unique due to the presence of oxazole, indole and aryltryptamine units and show potent antitumour activities. The Magnus and Moody groups have independently synthesised the different ring systems of these molecules 290 and 291, by using the SM cross-coupling reaction as the key step (Schemes 130a and

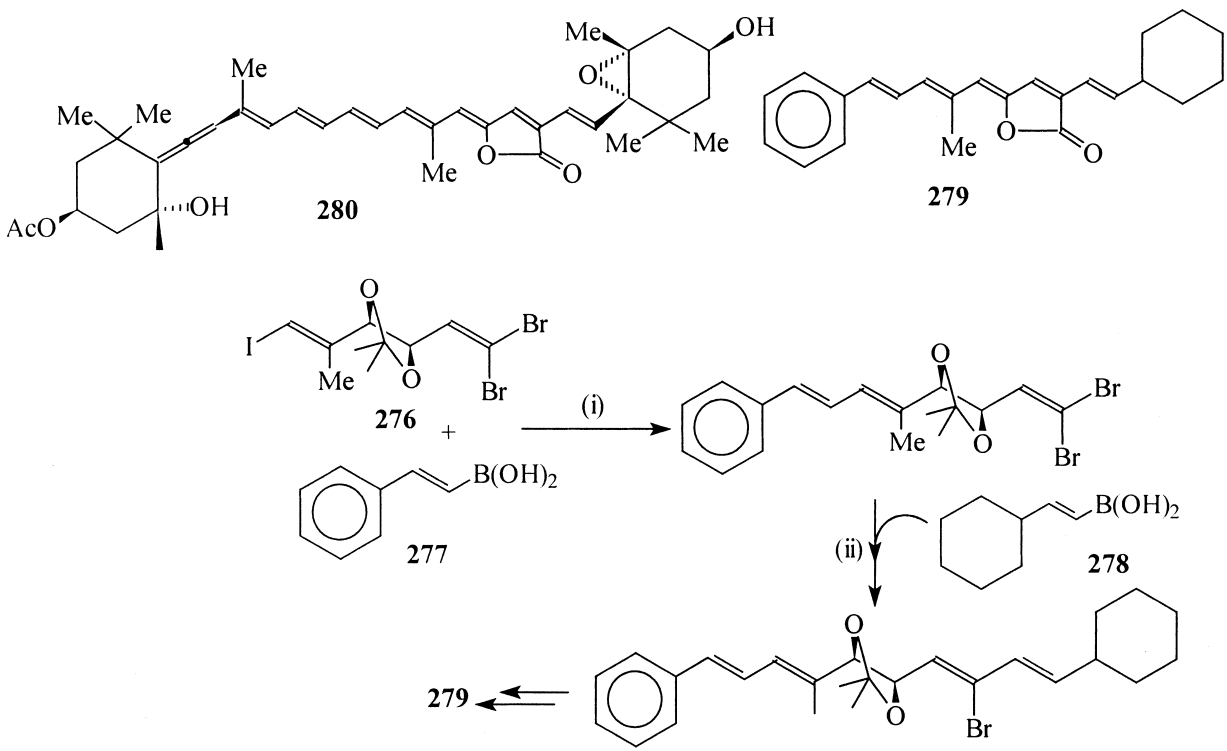




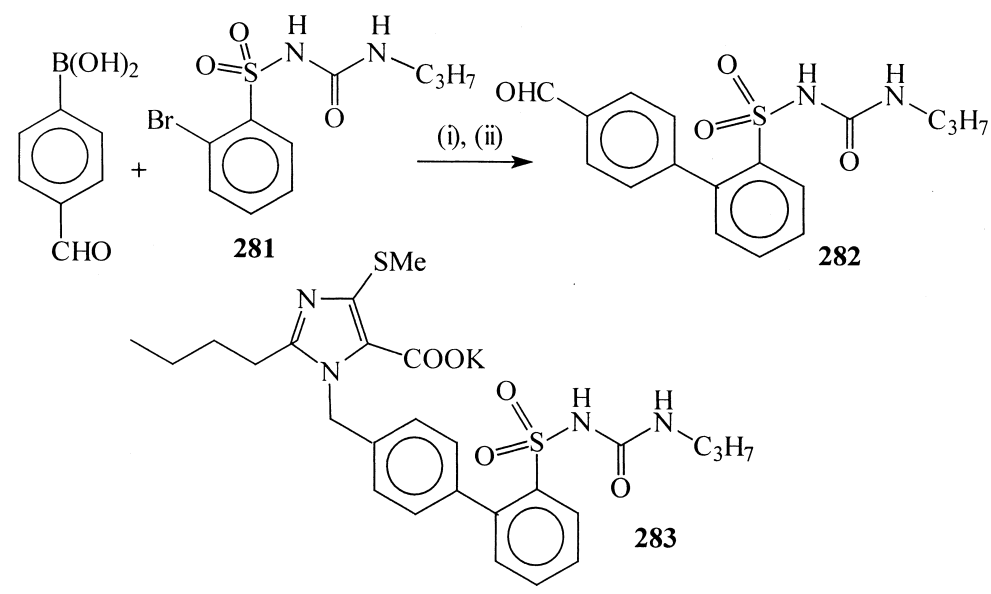

Scheme 127. (i) $\mathrm{Pd}(\mathrm{OAc})_{2}, \mathrm{PPh}_{3}, \mathrm{Cs}_{2} \mathrm{CO}_{3}$, toluene/EtOH/ $\mathrm{H}_{2} \mathrm{O}, 70^{\circ} \mathrm{C}$. (ii) $\mathrm{HCl}, \mathrm{H}_{2} \mathrm{O}, 75 \%$.

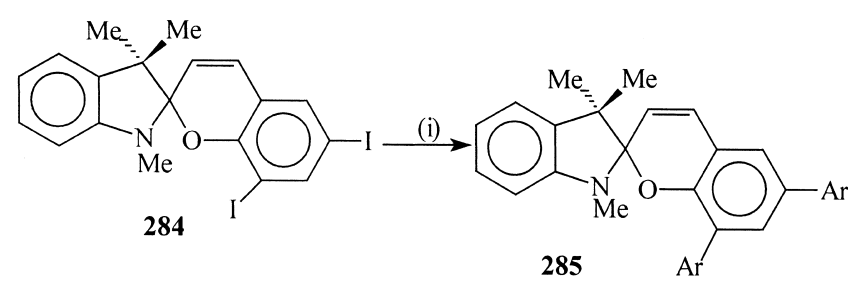

Scheme 128. (i) $\mathrm{ArB}(\mathrm{OH})_{2}, \mathrm{Pd}(\mathrm{OAc})_{2}(5 \mathrm{~mol} \%)$, aq. $\mathrm{Na}_{2} \mathrm{CO}_{3}, \mathrm{DMF}, 80^{\circ} \mathrm{C}$.

130b). ${ }^{278,279}$ In a related study, Vedejs and co-workers also reported the synthesis of the macrocyclic core 292 of diazonamide A by using the SM reaction of an oxazolylindole triflate with an arylboronic acid followed by a Dieckmann-type condensation (Scheme 131). ${ }^{280}$

Dawson et al. have reported a stereospecific synthesis of the anti-HIV compounds michellamine $\mathrm{A}$ and $\mathrm{C}$ via the SM cross-coupling reaction. ${ }^{281}$ In similar way, in 1999, de Koning and co-workers synthesised an isochroman analogue 296 of michellamines by using the $\mathrm{Pd}\left(\mathrm{PPh}_{3}\right)_{4}-$ catalysed SM cross-coupling reaction of 5-iodo-6,8dimethoxy-1,3-trans-dimethylisochroman 293 with the appropriate naphthaleneboronic acid 294 to give 295 followed by further transformations (Scheme 132a). ${ }^{282}$

Subsequently, Mori and co-workers synthesised diospyrin
297, an active natural product against leishmaniasis and other parasitic protozoan diseases, by using the SM crosscoupling reaction as the key step (Scheme 132b). ${ }^{283}$

Retinoid receptor ligands such as $\mathbf{2 9 8}$ are important medicinal compounds because of their structural similarity with vitamin A. Faul and co-workers have reported the synthesis of these compounds by the SM coupling reaction as shown in Scheme 133. ${ }^{284 a}$ In a similar way, de Lera and co-workers also reported the stereocontrolled synthesis of 9-cis-retinoic acid and its analogues by using a thallium-accelerated SM cross-coupling reaction of cyclohexenylboronates and the corresponding iodides as the key step. ${ }^{284 \mathrm{~b}}$

Nakamura and co-workers have synthesised DL-cypridina luciferin 302, a bioluminescent natural product, via a $\mathrm{Pd}\left(\mathrm{PPh}_{3}\right)_{4}$-catalysed $\mathrm{SM}$ cross-coupling reaction of the bromopyrazine 299 with $N$-tosylindol-3-boronic acid $\mathbf{3 0 0}$ to give a key intermediate 301. Further functional group transformations gave $\mathbf{3 0 2}$ (Scheme 134). ${ }^{285}$ The same workers also synthesised its oxygen and sulphur analogues by using the appropriate benzofuran and benzothiophene boronic acids as the starting materials.

The $\operatorname{Pd}(0)$-catalysed SM cross-coupling reaction of $o$ pivaloylaminophenylboronic acid 303 with 304 gave an intermediate $\mathbf{3 0 5}$ which on sequential functional group

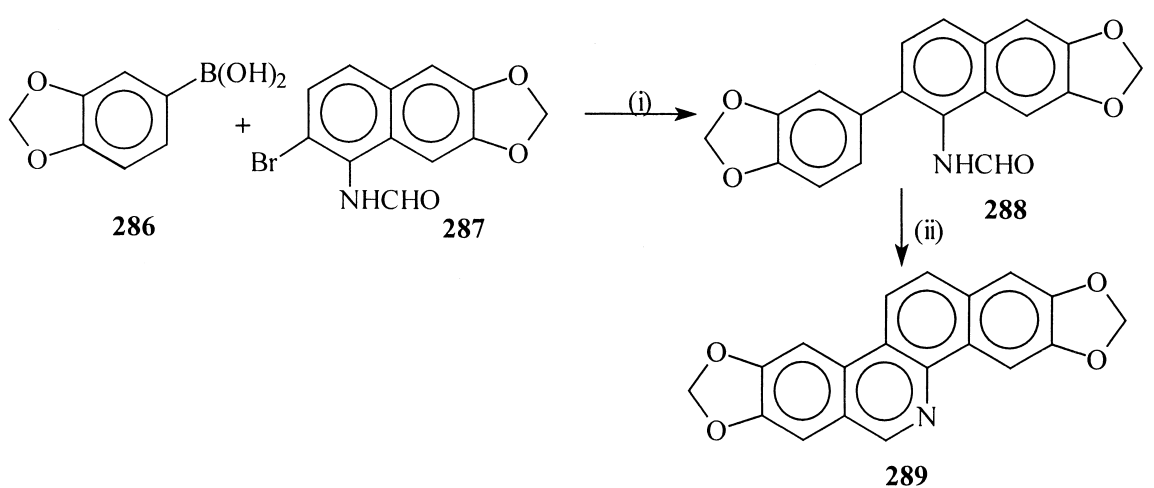

Scheme 129. (i) $\mathrm{Pd}(\mathrm{OAc})_{2}, \mathrm{PPh}_{3}$, aq. $\mathrm{Na}_{2} \mathrm{CO}_{3}, 4$ h, 79\%. (ii) $\mathrm{POCl}_{3}, \mathrm{MeCN}$, reflux, 30 min, $93 \%$. 
(a)<smiles>COc1ccccc1CCCCOc1ccccc1-c1cccc([N+](=O)[O-])c1CC(C)=O</smiles><smiles>COc1ccccc1-c1cccc2[nH]c(Cl)c(C(=O)C(=O)Cl)c12</smiles>

(b)

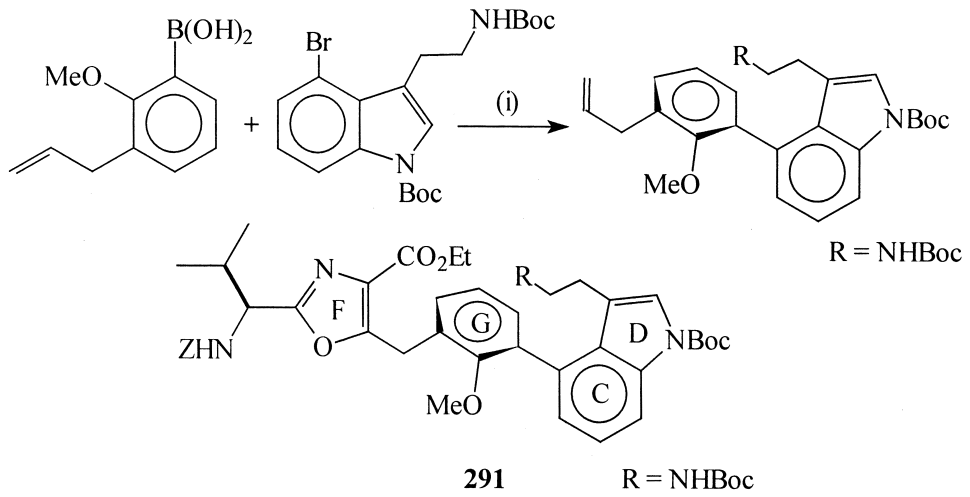

Scheme 130. (a) (i) $\mathrm{Pd}\left(\mathrm{PPh}_{3}\right)_{4}$, aq. $\mathrm{Na}_{2} \mathrm{CO}_{3}, \mathrm{MeOH}$, reflux, 95\%. (b) (i) $\mathrm{Pd}\left(\mathrm{PPh}_{3}\right)_{4}, \mathrm{Cs}_{2} \mathrm{CO}_{3}, \mathrm{DME}, 90 \%$.
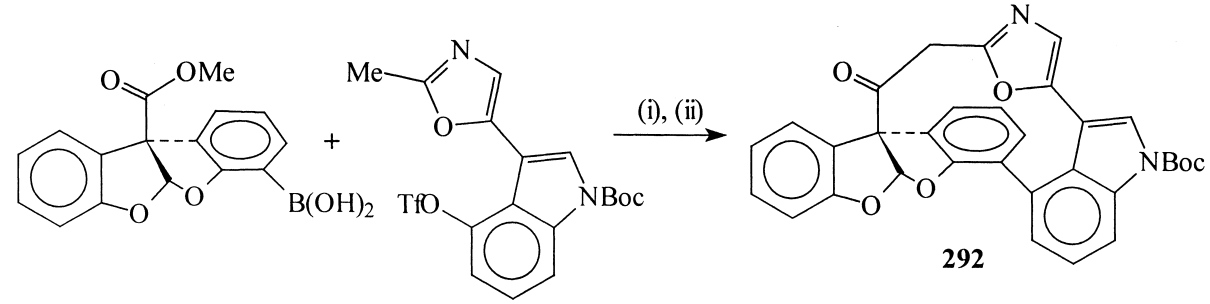

Scheme 131. (i) $\mathrm{PdCl}_{2}$ (dppf), $\mathrm{Cs}_{2} \mathrm{CO}_{3}$, THF, $85^{\circ} \mathrm{C}, 15$ h. (ii) LDA, THF, $-23^{\circ} \mathrm{C}$.

transformation gave the biologically active heteroaromatic $\beta$-carboline-fused systems $\mathbf{3 0 6}$ and $\mathbf{3 0 7}$ (Scheme 135). ${ }^{286}$

Diarylfuranone derivatives act as cyclooxygenase inhibitors. In this respect, Chung and co-workers have reported the synthesis of a series of 2,2-dimethyl-5-[4-(methylsulphonyl)phenyl]-4-phenyl-3-(2H)furanones, e.g. 310 involving the $\mathrm{Pd}\left(\mathrm{PPh}_{3}\right)_{4}$-catalyzed $\mathrm{SM}$ cross-coupling reaction of the corresponding iodide $\mathbf{3 0 8}$ with the arylboronic acid $\mathbf{3 0 9}$ as a key step (Scheme 136). ${ }^{287}$

\subsection{Reactions involving 9-BBN derivatives}

The SM cross-coupling reaction has played an important role in the synthesis of complex natural products like ciguatoxin, gambierol, epothilone, phomactin, and halichlorine. In this regard, hydroboration of alkenes followed by the SM cross-coupling reaction has been used as a key step and the details are discussed here. A generalised schematic diagram of the hydroboration reaction of terminal alkenes with 9-BBN and the Pd-catalysed cross-coupling with vinyl halides or phosphates is shown in Scheme 137. The newly formed $\mathrm{C}-\mathrm{C}$ bond is depicted by a wavy line.
The Panek and Danishefsky groups have used hydroboration and the B-alkyl SM cross-coupling protocol for constructing a single bond between $\mathrm{C} 11-\mathrm{C} 12$ units in synthesising the cytotoxic macrolides, epothilone A $\mathbf{3 1 3}$ and epothilone B 314. Their strategy involves the hydroboration of the terminal olefin intermediates and the $\mathrm{PdCl}_{2}(\mathrm{dppf})$ catalysed SM cross-coupling with other key intermediates containing a vinyl iodide moiety to generate $\mathbf{3 1 1}$ and $\mathbf{3 1 2}$ which on epoxidation gave $\mathbf{3 1 3}$ and $\mathbf{3 1 4}$ (Scheme 138). ${ }^{288,289}$

Ciguatoxin and gambierol are polycyclic ethers containing marine natural products and show potent cytotoxic activities. Tachibana and co-workers have developed a simple methodology for the synthesis of the ABCD and HIJK ring systems 315 and 316 of ciguatoxin and the EFGH ring systems 317 of gambierol. Their strategies involve the preparation of the key intermediates by using a hydroboration reaction of exo-olefins with 9-BBN followed by the $\mathrm{Pd}\left(\mathrm{PPh}_{3}\right)_{4}$-catalysed B-alkyl SM cross-coupling reaction with ketene acetal phosphates as the key step (Scheme 139). ${ }^{290-292}$

The macrocyclic ring system of the bioactive diterpene phomactin D 318 has been assembled by Halcomb and 
(a)<smiles>COc1cc(OC)c2c(c1-c1ccc(OC)c3c(OC)cc(OC)c(OC)c13)CC(C)OC2C</smiles><smiles>COc1cc(OC)c2c(c1-c1cc(-c3c(O)cc(OC)c4c3CC(C)O[C@H]4C)c(O)c3c(OC)cc(C)cc13)CC(C)OC2C</smiles>

(b)<smiles>COc1cc(C)cc2c1C(=O)C=C([Br+]Br)C2=O</smiles>

Scheme 132. (a) (i) $\mathrm{Pd}\left(\mathrm{PPh}_{3}\right)_{4}, \mathrm{~K}_{3} \mathrm{PO}_{4}, \mathrm{DMF}, 100^{\circ} \mathrm{C}, 85 \%$. (b) (i) $\mathrm{Pd}\left(\mathrm{PPh}_{3}\right)_{4}$, aq. $\mathrm{Na}_{2} \mathrm{CO}_{3}$, EtOH, toluene, reflux, $53 \%$.

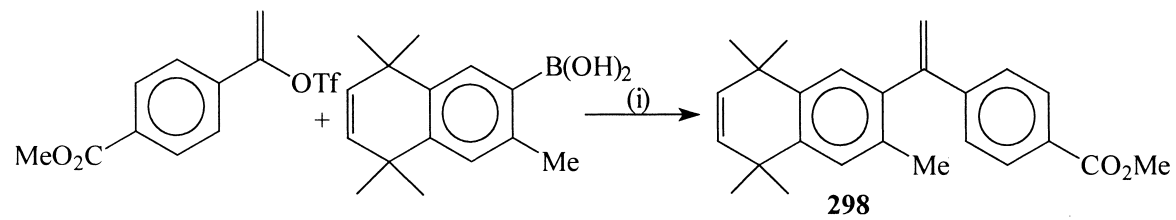

Scheme 133. (i) $\mathrm{Pd}(\mathrm{OAc})_{2}, \mathrm{P}(o \text {-tol })_{3}, \mathrm{DMF}, \mathrm{Et}_{3} \mathrm{~N}, 50^{\circ} \mathrm{C}, 81 \%$.

co-workers by using the intramolecular B-alkyl SM crosscoupling protocol without isolating the hydroboration product which underwent the coupling reaction in the final step (Scheme 140). ${ }^{293}$

In 1999, Danishefsky's group reported the total synthesis of (+)-halichlorine 320, an immunoglobulin inhibitor, by using the B-alkylated SM cross-coupling reaction of $Z$-iodoacrylate with the borane to give $\mathbf{3 1 9}$ and deprotection and intramolecular Michael addition as the key steps (Scheme 141). ${ }^{294}$

Baldwin et al. reported a simple method for the preparation of 3-alkylpyridines which are useful for the synthesis of the marine alkaloids, haliclamine A 321a and B 321b, based on the B-alkyl SM coupling of the long chain olefin and 3-bromopyridine shown in Scheme 142. ${ }^{295}$

Phlorizin (a $\beta$-arylglucoside) is a useful drug molecule for the treatment of diabetes-related deseases, but it metabolises easily into the less active compound, phloretin. In order to overcome this problem, Link et al. have reported an efficient method for the preparation of the phlorizin-related molecules by the hydroboration of the exo-glycal $\mathbf{3 2 2}$ followed by a cross-coupling reaction with the corresponding bromo and triflate derivatives $\mathbf{3 2 3}$ under $\mathrm{PdCl}_{2}(\mathrm{dppf}) \cdot \mathrm{CH}_{2} \mathrm{Cl}_{2}$ catalytic conditions to give the $\beta$-C-glycoside 324 (Scheme 143). ${ }^{296}$ 
$\overbrace{\mathrm{N} T_{3}}^{\mathrm{NHBOC}}$

299<smiles>[OH2+]c1cn([I-])c2ccccc12</smiles>

300<smiles>CCC(C)c1nc2c(CNC(=N)N)[nH]c(-c3c[nH]c4ccccc34)cn-2c1=O</smiles>

302

Scheme 134. (i) $\mathrm{Pd}\left(\mathrm{PPh}_{3}\right)_{4}$, aq. $\mathrm{Na}_{2} \mathrm{CO}_{3}$, toluene/THF, reflux, $80 \%$.

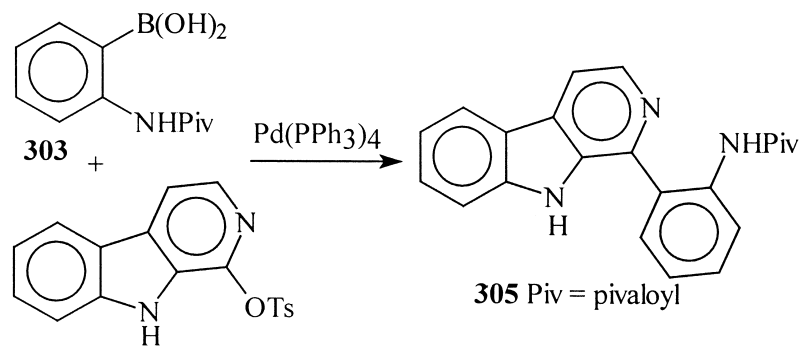

304<smiles>[B-]N1Nc2ccccc2-c2c1[nH]c1ccccc21</smiles>

306<smiles>Cn1c2ccccc2c2c3[nH]c4ccccc4c3cc[n+]21</smiles>

307
Scheme 135 .
Tetralones are useful intermediates for synthesising terpenoids such as helioporin and seco-pseudopterosins. Recently, Plumet et al. prepared a series of tetralones such as $\mathbf{3 2 5}$ by using B-alkylated SM cross-coupling followed by an intramolecular Friedel-Crafts acylation reaction (Scheme 144). ${ }^{297}$

Johnson and Johns have reported the synthesis of the glycosidase inhibitor bis-aza sugar $\mathbf{3 2 8}$ by using the double SM cross-coupling reaction. The required borane is prepared from the terminal diene $\mathbf{3 2 6}$ and is coupled with the vinyl bromide 327 (Scheme 145). ${ }^{298}$ Recently, Fürstner has reported an efficient one-pot synthesis of the alkylresorcinol 332 by the hydroboration of compound $\mathbf{3 2 9}$ with 9-BBN, selective protonation of the central 9-BBN to give an intermediate $\mathbf{3 3 0}$ followed by coupling with the triflate 331 to produce 332 in $62 \%$ overall yield (Scheme 146). ${ }^{299}$

In connection with the synthesis of the precursors of the enzyme inhibitor CP-225917 and CP-263114 compounds, Danishefsky and co-workers have used the $\mathrm{PdCl}_{2}$ (dppf)catalysed B-alkylated SM cross-coupling reaction for introducing an alkyl group into the key intermediate $\mathbf{3 3 3}$ to give $\mathbf{3 3 4}$ which can be further used for the preparation of the CP compounds (Scheme 147). ${ }^{300}$

\subsection{Reactions involving pinacol borane, catechol borane and boroxines}

Buffadienolide and related compounds are an important class of steroids and they are useful for the regulation of the mammalian sodium pump. In this respect, Jones et al. have reported a simple route for the synthesis of this type of compounds such as $\mathbf{3 3 7}$ by using the Pd-catalysed SM crosscoupling reaction of the 2-pyrone-5-boronate 335 with steroidal vinyl triflates e.g. 336 under optimised conditions in good yields (Scheme 148). ${ }^{301}$

Dimeric pyranonaphthaquinone-related natural products<smiles>[X]C1=C(c2ccc(S(C)(=O)=O)cc2)OC(C)(C)C1=O</smiles>

Scheme 136. (i) $\mathrm{Pd}\left(\mathrm{PPh}_{3}\right)_{4}, \mathrm{NaHCO}_{3}$, toluene/EtOH, $90^{\circ} \mathrm{C}, 12 \mathrm{~h}, 68 \%$.

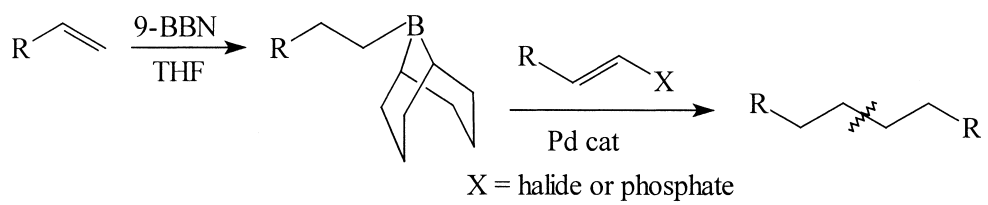

Scheme 137. 


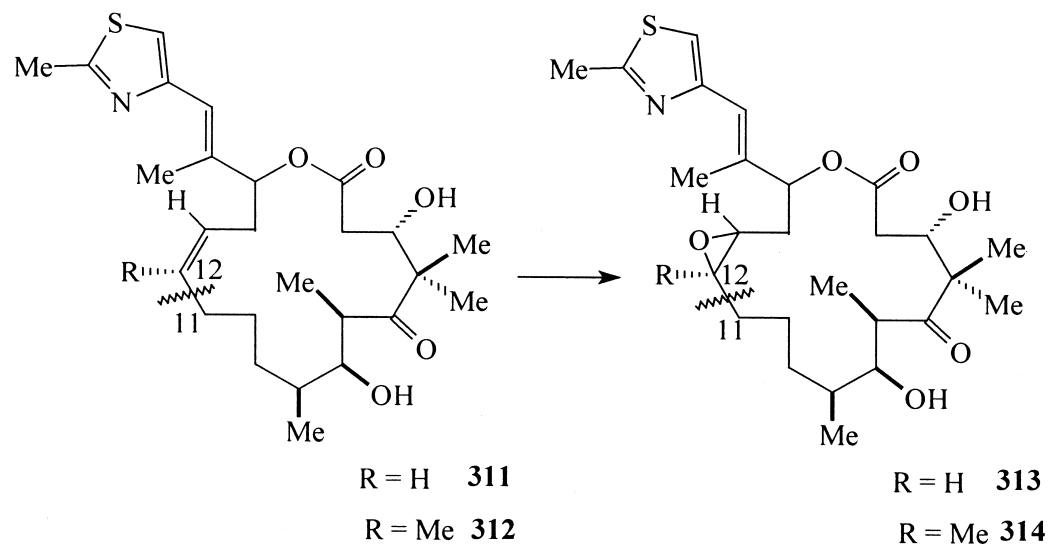

Scheme 138.

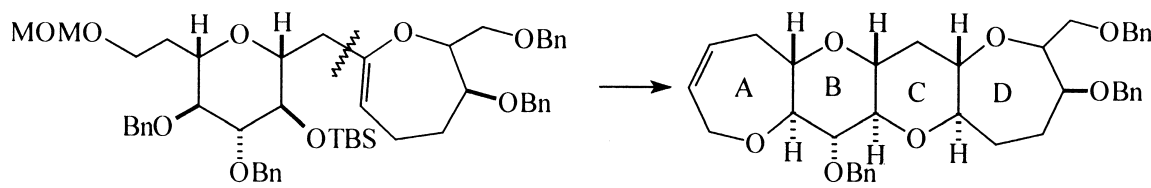

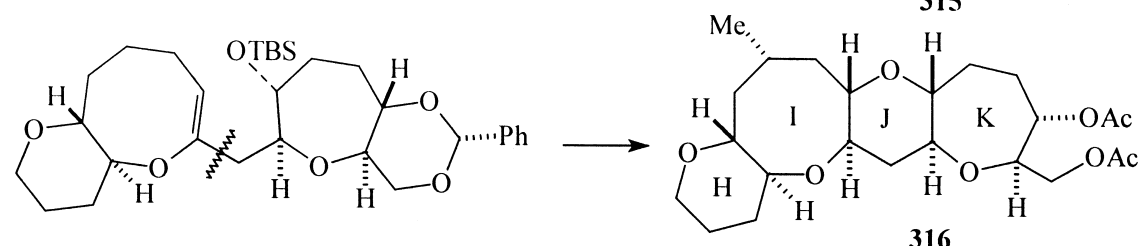<smiles>CCCCOC1CC(O)C(CCOCc2ccccc2)OC1CC1=CCC[C@H]2OC(c3ccccc3)OCC2O1</smiles>

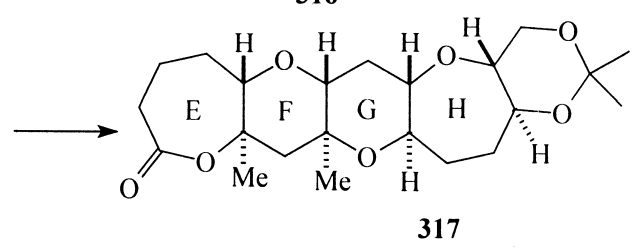

Scheme 139 .

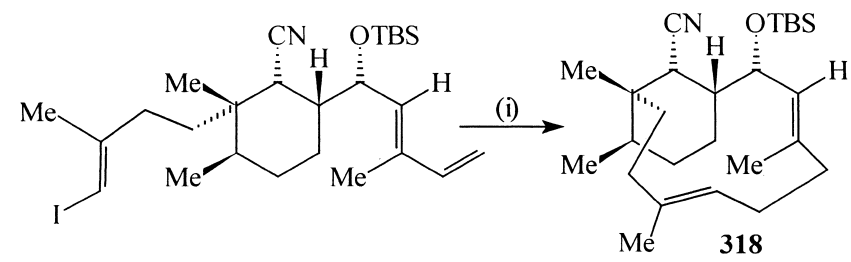

Scheme 140. (i) 9-BBN, toluene, $50^{\circ} \mathrm{C} ; \mathrm{PdCl}_{2}$ (dppf), $\mathrm{AsPh}_{3}, \mathrm{Cs}_{2} \mathrm{CO}_{3}$, $\mathrm{DMF} / \mathrm{H}_{2} \mathrm{O}, 50^{\circ} \mathrm{C}, 16 \%$. such as $340 \mathrm{a}$ and $340 \mathrm{~b}$ have been prepared by using the SM cross-coupling protocol of the bromonaphthalene $\mathbf{3 3 8}$ with the pinacolborane $\mathbf{3 3 9}$ as the key steps (Scheme 149). ${ }^{302}$

Walsh et al. reported a convergent approach for the synthesis of the $(S)$ - $\beta$-methyl-2-aryltryptamine moietycontaining gonadotropin releasing harmone antagonist 344 by using the $\mathrm{PdCl}_{2}$ (dppf) $\cdot \mathrm{CH}_{2} \mathrm{Cl}_{2}$-catalysed $\mathrm{SM}$ crosscoupling reaction of 2 -iodo- $(S)-\beta$-methyltryptophol 341
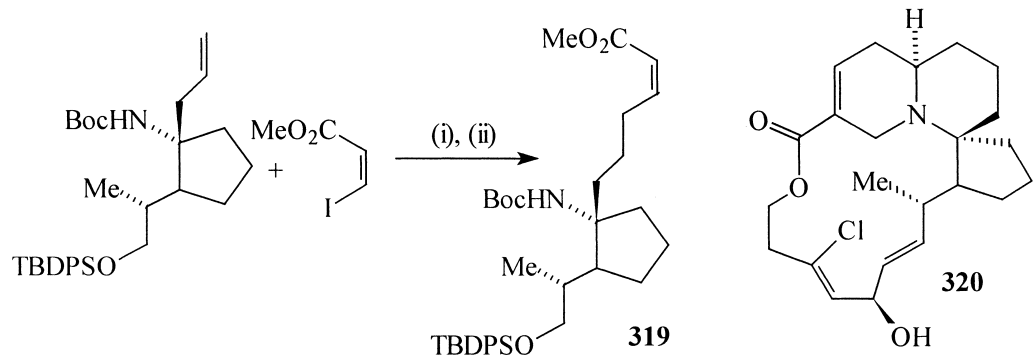

Scheme 141. (i) 9-BBN, THF. (ii) $\mathrm{PdCl}_{2}$ (dppf), $\mathrm{AsPh}_{3}, \mathrm{Cs}_{2} \mathrm{CO}_{3}, \mathrm{DMF}, \mathrm{H}_{2} \mathrm{O}$. 


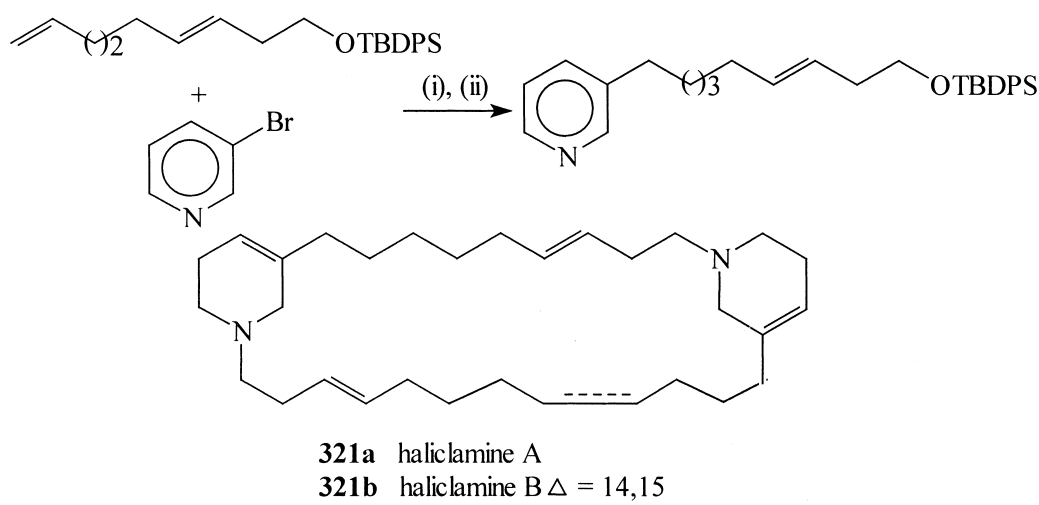

Scheme 142. (i) 9-BBN, THF/ultrasound. (ii) $\mathrm{Pd}\left(\mathrm{PPh}_{3}\right)_{4}$, aq. $\mathrm{K}_{3} \mathrm{PO}_{4}, 65 \%$.

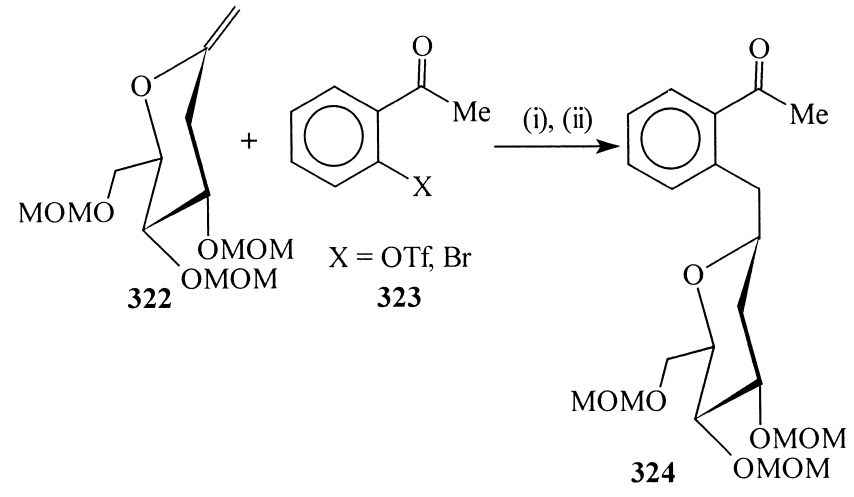

Scheme 143. (i) 9-BBN, THF, reflux, 5 h. (ii) $\mathrm{PdCl}_{2}$ (dppf), $\mathrm{CH}_{2} \mathrm{Cl}_{2}, \mathrm{~K}_{3} \mathrm{PO}_{4}$, DMF, $\mathrm{H}_{2} \mathrm{O}, \mathrm{RT}, 18 \mathrm{~h}, 55 \%$. with 4,4,5,5-tetramethyl-2-(3,4,5-trimethylphenyl)-1,3,2dioxaborolane $\mathbf{3 4 2}$ as the key step to give $\mathbf{3 4 3}$ and other functional group tranformations (Scheme 150). ${ }^{303}$

Tuberin, erbstatin and aspergillamide are some bioactive natural products in which a $\beta$-arylenamide moiety is present as the basic skeleton. Recently, Witulski and co-workers have reported a one-pot synthesis of the $\beta$-arylenamides 347 by in situ generation of the $E$-vinylborane 346 from the chemo- and regioselective hydroboration of the 1-alkynylamine 345 with catechol borane followed by the Pd-catalysed SM cross-coupling reaction with aryl bromides and iodides in good yields (Scheme 151). ${ }^{304}$

Baldwin and co-workers have demonstrated a biomimetic<smiles>CC=C(C)C1Oc2ccc(CCCC(C)=O)c(C)c2O1</smiles>

Scheme 144. (i) 9-BBN-( $\left.\mathrm{CH}_{2}\right)_{3} \mathrm{CO}_{2} \mathrm{CH}_{3}, \mathrm{PdCl}_{2}$ (dppf), NaOMe, THF, RT, $72 \%$. (ii) polyphosphonate ester, $\mathrm{CHCl}_{3}, \mathrm{RT}, 87 \%$.

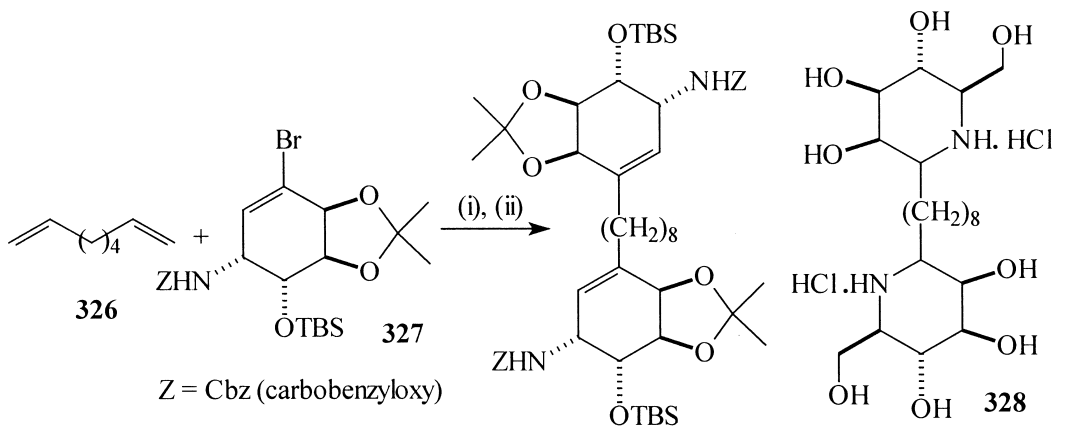




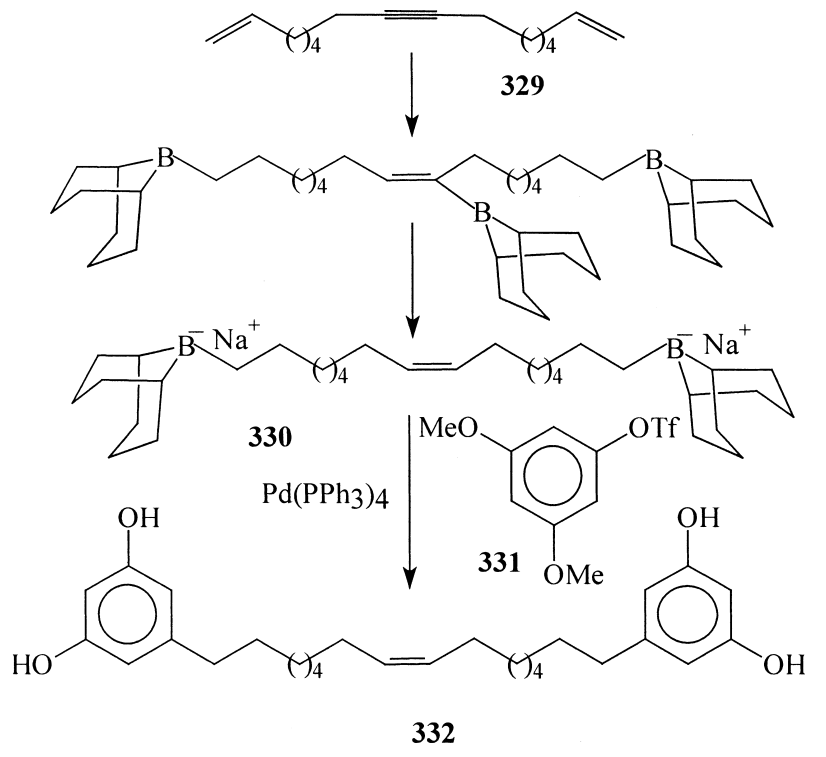

Scheme 146.

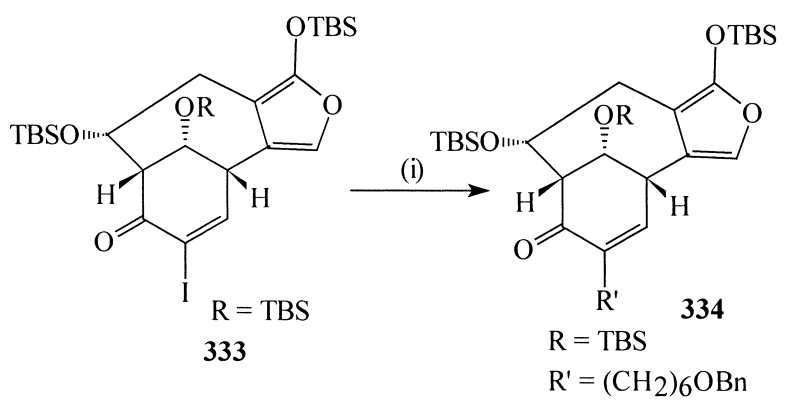

Scheme 147. (i) $\mathrm{B}\left[\left(\mathrm{CH}_{2}\right)_{6} \mathrm{OBn}\right]_{3}, \mathrm{PdCl}_{2}(\mathrm{dppf}), \mathrm{AsPh}_{3}, \mathrm{Cs}_{2} \mathrm{CO}_{3}, \mathrm{H}_{2} \mathrm{O}, 70 \%$.

approach towards the synthesis of non-adride-related compounds such as $\mathbf{3 4 8}$. Here, the SM cross-coupling and intramolecular cyclisation of dimeric bis-anhydride compounds were used as the key steps (Scheme 152). ${ }^{305}$

Caparratriene is useful for treating leukemia and cancerrelated diseases. In 1999, Vyvyan et al. have synthesised caparratriene 351 from citronellal 349 in a three-step sequence by using Corey-Fuchs homologation to obtain the terminal alkyne $\mathbf{3 5 0}$ followed by in situ generation of the $E$-vinylborane and SM cross-coupling reaction with

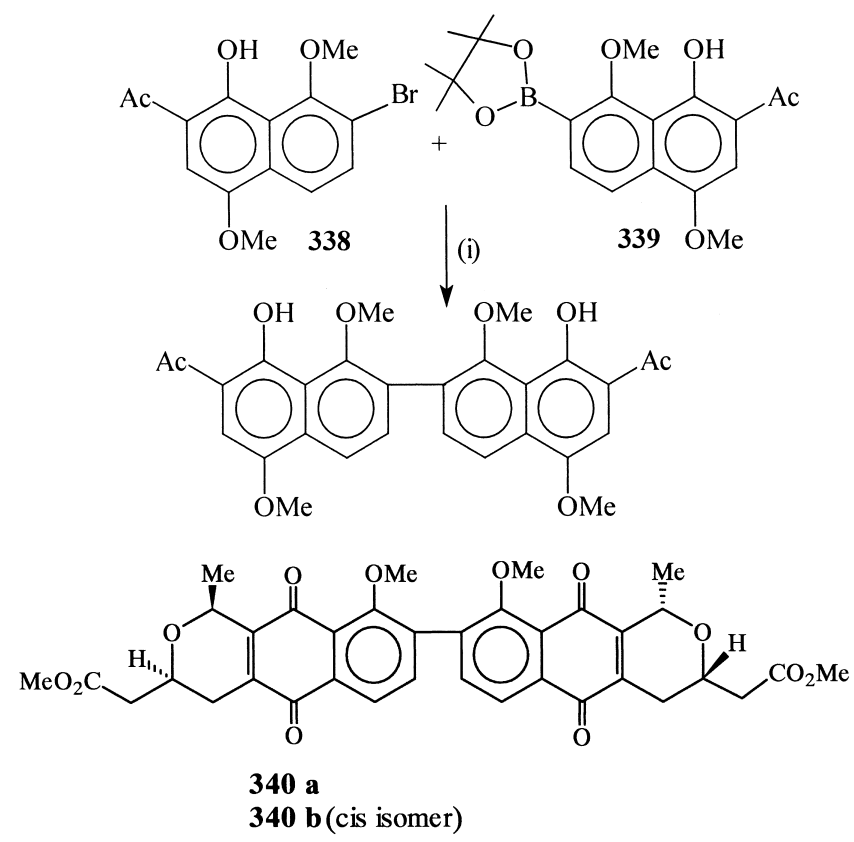

Scheme 149. (i) $\mathrm{PdCl}_{2}$ (dppf), CsF, THF, reflux, $25^{\circ} \mathrm{C}, 53 \%$.

$E$-2-bromo-2-butene in 56\% yield. This strategy is superior to that of the earlier reports (Scheme 153). ${ }^{306}$

Wong and Yick prepared eudesmanolide-related molecules of the type $\mathbf{3 5 5}$ by utilising the SM cross-coupling reaction of tris(4-methylfuran-3-yl)boroxine $\mathbf{3 5 2}$ with ethyl-4bromo-3-methoxycrotonate 353 to give the key intermediate 354 which on further sequential transformations gave the required products in good yields (Scheme 154). ${ }^{307}$

\section{Solid supported synthesis}

Although polymer-bound boronic acids were reported as early as $1976,{ }^{308}$ Frenette and Friesen, ${ }^{309}$ in 1994, investigated the utility of the SM coupling reaction on a solid support for combinatorial chemistry. The recent emergence of various techniques (e.g. solutionphase combinatorial synthesis, resin capturing and resin scavenging, ion-exchange for acid-base extraction, fluorous-phase extraction and synthesis of soluble polymers) has further enhanced the application of solid phase synthesis. A number of linkers have been developed to

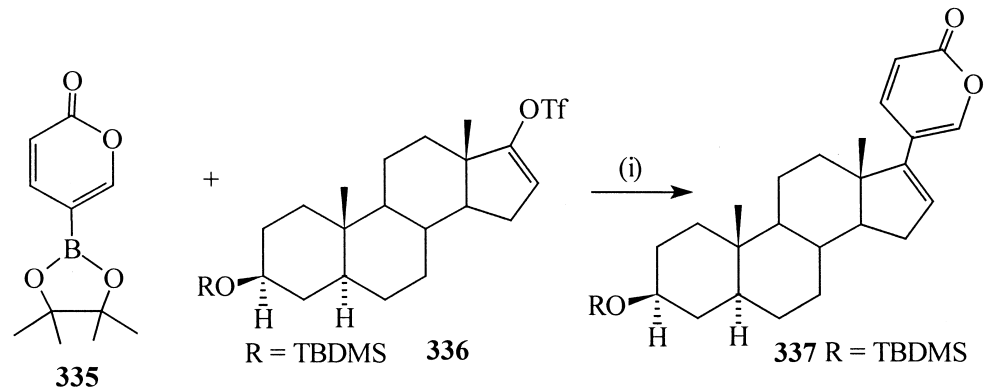

Scheme 148. (i) $\mathrm{PdCl}_{2}$ (dppf) (0.1 equiv.), $\mathrm{K}_{3} \mathrm{PO}_{4}$, DMF, $60^{\circ} \mathrm{C}, 6 \mathrm{~h}, 91 \%$. 


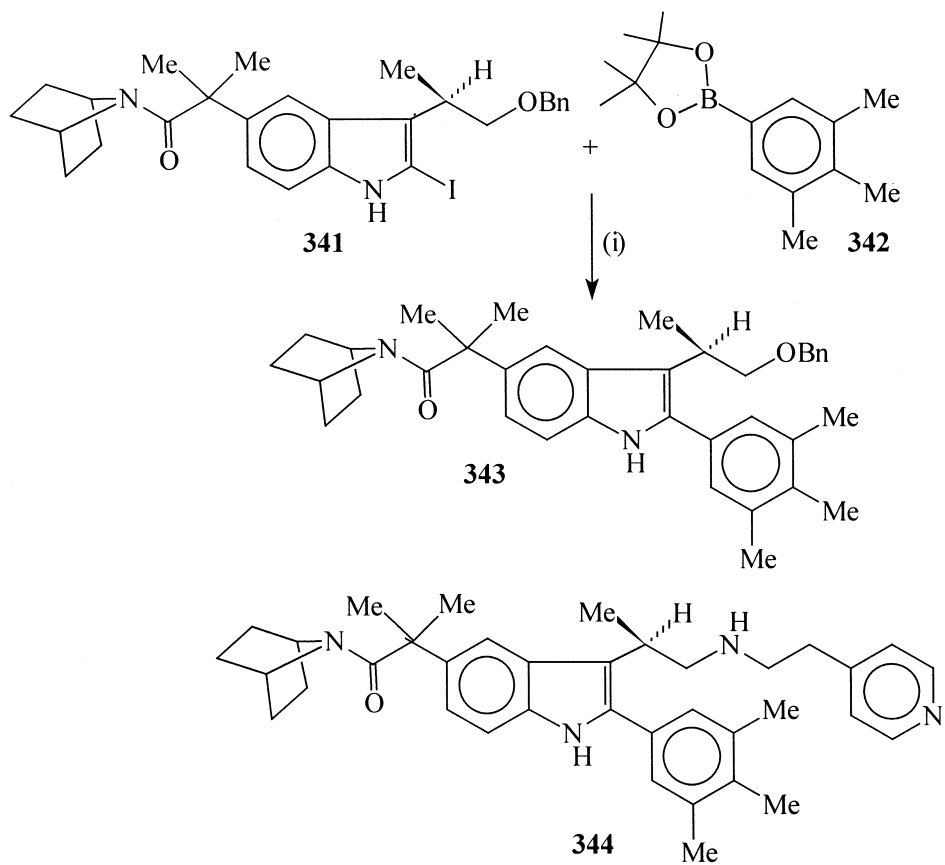

Scheme 150. (i) $\mathrm{PdCl}_{2}$ (dppf), $\mathrm{CH}_{2} \mathrm{Cl}_{2}$, toluene/EtOH, $\mathrm{Na}_{2} \mathrm{CO}_{3}, 85^{\circ} \mathrm{C}, 15 \mathrm{~h}, 96 \%$.

immobilise the substrates or catalysts on a solid support, but there still is need for novel linker systems which are sufficiently stable under various reaction conditions. At the same time, however, it is desirable to selectively remove the linkers using special conditions in the cleavage step.

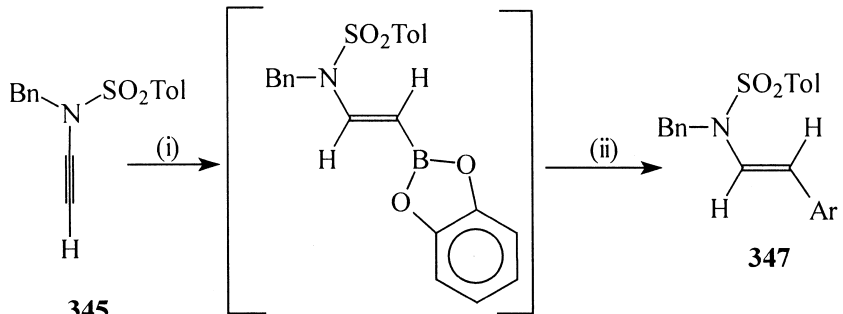

346

Scheme 151. (i) Catechol borane (1.5 equiv.), THF, $70^{\circ} \mathrm{C}, 2 \mathrm{~h}$. (ii) $\mathrm{Ar}-\mathrm{X}$ $(\mathrm{X}=\mathrm{Br}, \mathrm{I}), \mathrm{Pd}\left(\mathrm{PPh}_{3}\right)_{4}(10 \mathrm{~mol} \%), 80^{\circ} \mathrm{C}, 4 \mathrm{~h}$, sealed tube.

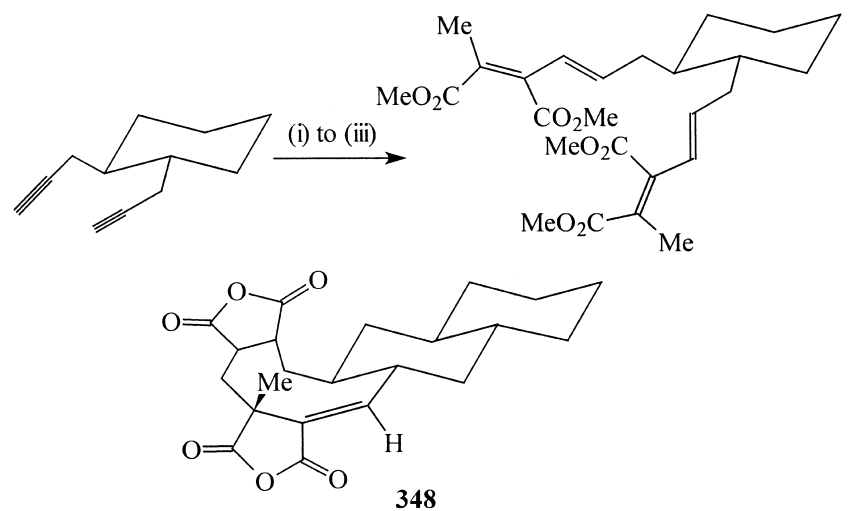

Scheme 152. (i) Catechol borane. (ii) $\mathrm{Pd}_{2}(\mathrm{dba})_{3}$. (iii) 2-Iodo-3-methyl dimethyl maleate, $44 \%$.
In view of the production of libraries of small organic molecules for biological screening, the transition metalpromoted reactions are useful tools because they proceed under mild reaction conditions and are compatible with many functional groups. The solid-phase SM cross-coupling strategy has been largely developed by reacting the resinbound aryl halides with solution-phase boronic acids. Recently, methods have been developed for attaching boronic acids to macroporous polymer supports and these supported boronic acids have been successfully used as reagents in the SM cross-coupling reaction. Selected examples 356-371 involving the solid-phase SM crosscoupling reactions are shown in Scheme $155^{310-322}$ and, for extended examples, readers may refer to recent reviews/ monographs. ${ }^{323}$

\section{Formation of carbon-heteroatom $(\mathrm{C}-\mathrm{N}, \mathrm{C}-\mathrm{O}$ and $\mathrm{C}-\mathrm{S})$ bonds}

From the above discussions, it is clear that the Pd-catalysed SM cross-coupling reaction is a useful tool for the formation of $\mathrm{C}-\mathrm{C}$ single bonds between aryl-aryl, aryl-alkyl, alkene and alkynyl systems. In addition, it has recently been shown that the SM type cross-coupling reaction of boronic acids

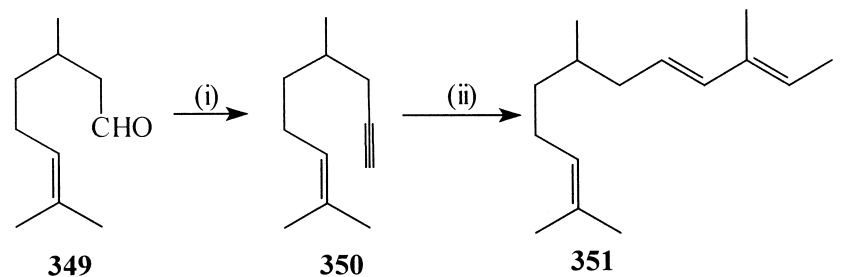

Scheme 153. (i) $\mathrm{CBr}_{4}, \mathrm{Zn}, n$-BuLi. (ii) Catechol borane, E-2-bromo-2butene, $\mathrm{Pd}\left(\mathrm{PPh}_{3}\right)_{4}(5 \mathrm{~mol} \%), \mathrm{NaOEt}$, benzene, reflux, $56 \%$. 


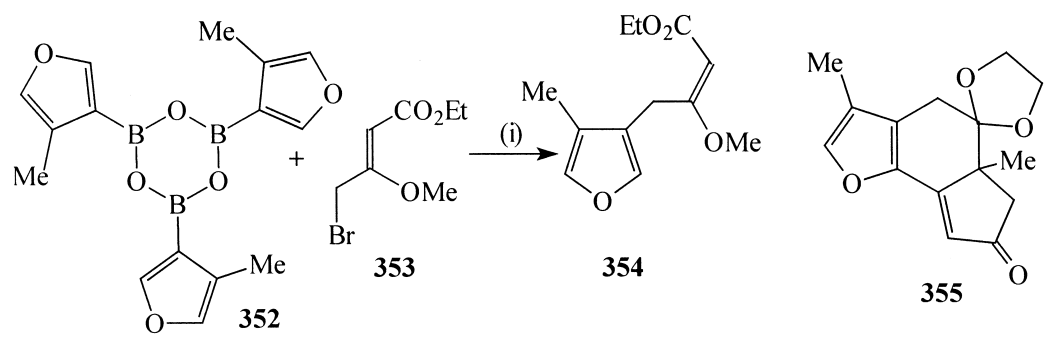

Scheme 154. (i) $\mathrm{Pd}(\mathrm{dba})_{2}, \mathrm{THF}, \mathrm{K}_{3} \mathrm{PO}_{4}$, reflux, $60 \%$.

with amines, hydroxy compounds and alkyl sulphides is useful for the formation of carbon-heteroatom (e.g. C-N, $\mathrm{C}-\mathrm{O}$ and $\mathrm{C}-\mathrm{S}$ ) single bonds.

In 1998, Chan et al. developed a simple method for $\mathrm{N}$ - and $O$-arylation reactions involving the $\mathrm{Cu}(\mathrm{OAc})_{2}$-catalysed reaction of $\mathrm{N}-\mathrm{H}$ and $\mathrm{O}-\mathrm{H}$ functional group-containing substrates with arylboronic acids at RT. ${ }^{324,325}$ The resultant products $\mathbf{3 7 2}-\mathbf{3 8 3}$ are given in Fig. 16 and the newly formed $\mathrm{C}-\mathrm{N}$ and $\mathrm{C}-\mathrm{O}$ bonds are shown by a wavy line.

At almost the same time, Evans and co-workers synthesised

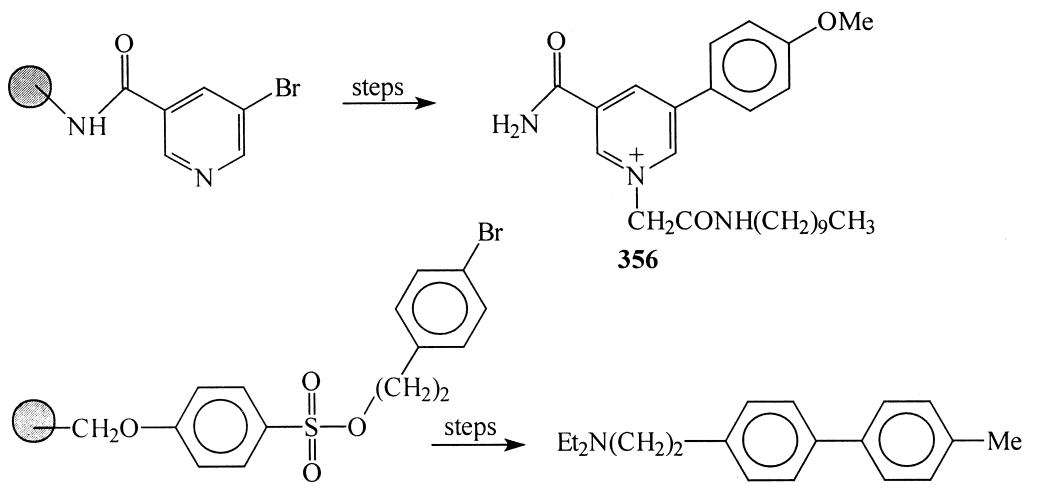

357<smiles>CC(C)CCCOCC1COC(c2ccc(Br)cc2)O1</smiles>

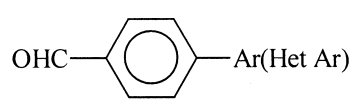

358<smiles>CC(=O)c1ccc(-c2cccc([N+](=O)[O-])c2)cc1</smiles><smiles>O=C(O)c1ccc(-c2oc(Br)cc2COc2ccccc2)cc1</smiles><smiles>[Al]c1cc(CSc2ccc(Cl)cc2)c([AlH2])o1</smiles>

$\operatorname{Ar} 1=4$-carboxyphenyl $\mathrm{Ar}^{2}=3$-methoxyphenyl 360<smiles>CC1CCCCO1</smiles><smiles>O=C(O)c1ccc(-c2ccc(F)cc2)cc1</smiles> 
<smiles>N#Cc1ccc(-c2ccccc2)cc1</smiles><smiles>CC(=O)OC(=O)c1ccc2c(c1)C(C)(C/C=C/c1ccccc1)CN2C(C)=O</smiles>

363<smiles>[R]c1nc([R])c2nc(Br)n(C)c2n1</smiles><smiles>[R][R]=[W]=[Y]N1CCN(C)CC1</smiles><smiles>Cc1c(I)[nH]c2ccc(C(=O)N3CCCC3)cc12</smiles><smiles>Cc1c(-c2ccccc2)[nH]c2ccc(C(N)=O)cc12</smiles>

365<smiles>O=S(=O)([AlH2])n1c([AlH2])c(Br)c2ccccc21</smiles><smiles>C1CC2C[C+]1C2</smiles><smiles>N#[Y19]c1[nH]c2ccccc2c1[AlH2]</smiles>

$\mathrm{Ar} 1=4$-methylphenyl

$\mathrm{Ar}^{2}=4$-methoxyphenyl

366

Scheme 155 (continued)

sterically hindered diaryl ether amino acid derivatives including the hormone thyroxine (e.g. 387) from 386, which was prepared based on the reaction of the corresponding phenols $\mathbf{3 8 4}$ and the appropriate arylboronic acids 385 in the presence of $\mathrm{Cu}(\mathrm{OAc})_{2}$ and base (Scheme 156). ${ }^{326}$ The main drawback of these methods was the use of a stoichiometric amount of $\mathrm{Cu}(\mathrm{OAc})_{2}$. In order to overcome these problems, Collman et al. have recently reported the $\mathrm{N}$-arylation of imidazoles with boronic acids in the presence of a catalytic amount of $[\mathrm{Cu}(\mathrm{OH}) \cdot \mathrm{TMEDA}]_{2} \mathrm{Cl}_{2}$ as the copper source (Scheme 157). ${ }^{327}$ This procedure is not applicable, however, to the arylation of simple amines, anilines and phenols.

In view of these studies, Lam and co-workers reported the $\mathrm{Cu}(\mathrm{OAc})_{2}$-catalysed $\mathrm{N}$-arylation of different $\mathrm{NH}$-containing functional groups including amines, anilines and phenols with aryl- and vinylboronic acids by using $N$-methylmorpholine oxide, pyridine $N$-oxide, 2,2,6,6-tetramethyl-1piperidinyl oxide, etc. as additives which facilitates the oxidation of $\mathrm{Cu}(\mathrm{II})$ to $\mathrm{Cu}(\mathrm{III})$ and easy reductive elimination to form the $\mathrm{C}-\mathrm{N}$ and $\mathrm{C}-\mathrm{O}$ cross-coupled products (Scheme 158). ${ }^{328}$

Buchwald et al. also reported the reaction of amines and anilines with arylboronic acids by using myristic acid and 2,6-lutidine as additives which helps to enhance the rate of the reaction and to minimise the amount of catalyst (Scheme 159). ${ }^{329}$ Recently, Kelly and co-workers have synthesised the medicinally important aryloxyamines 389 based on $\mathrm{Cu}(\mathrm{OAc})_{2}$ - or $\mathrm{CuCl}_{2}$-catalysed reactions of $\mathrm{N}$-hydroxyphthalimide $\mathbf{3 8 8}$ and arylboronic acids followed by hydrazinolysis to afford the aryloxyamines 389 (Scheme 160). ${ }^{330}$

Evans et al. synthesised a biphenyl ether-linked macrocycle 391 which acts as a matrix metalloproteinase inhibitor by using the $\mathrm{Cu}(\mathrm{OAc})_{2}$-catalysed intramolecular $O$-arylation of the phenol function with the arylboronic acid group in 390 as a key step (Scheme 161). ${ }^{331}$ 


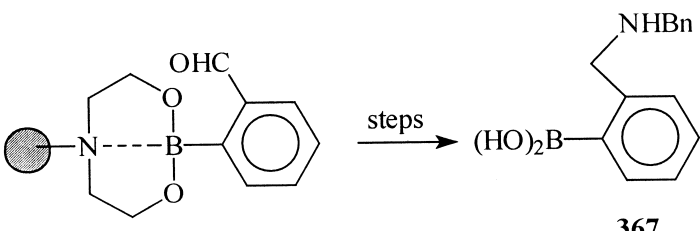

367

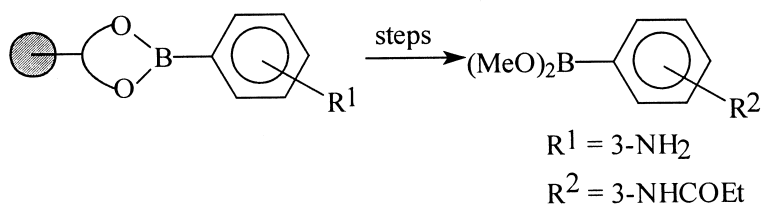

368
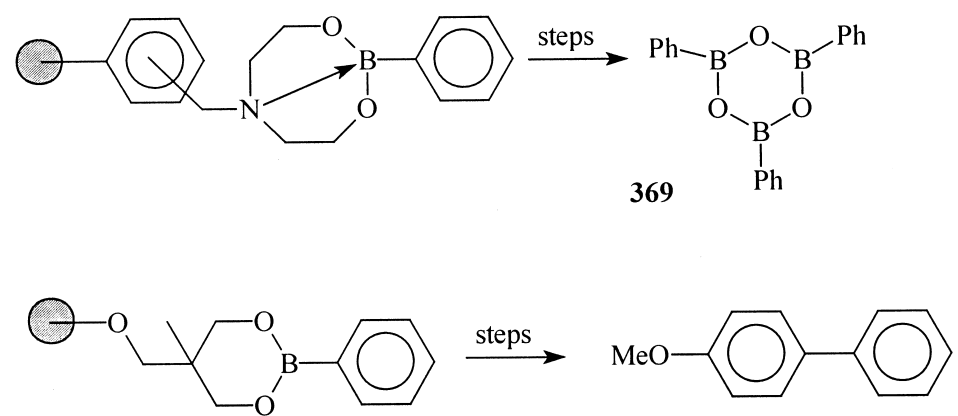

370<smiles>CN(c1cccc(Br)c1)c1cnc(C(Oc2cccc([N+](C)(C)C)c2)N2CCOCC2)o1</smiles>
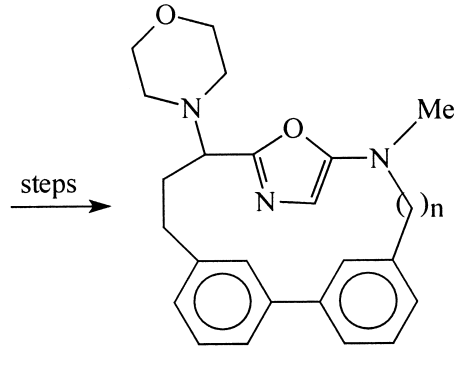

371

Scheme 155 (continued)

Guy and co-workers have developed a simple methodology for the synthesis of thioethers of the type 392 under mild conditions involving the $\mathrm{Cu}(\mathrm{OAc})_{2}$-catalysed reaction of arylboronic acids with alkanethiols as shown in Scheme 162.332

\section{Synthesis of diaryl ketones via carbonylative SM cross-coupling}

Diaryl ketones are useful intermediates in synthetic organic chemistry. Several conventional and catalytic methods are available in the literature for the synthesis of these compounds including Friedel-Crafts acylation and Pd-catalysed three-component cross-coupling reactions of arylmetal reagents (organotins), carbon monoxide and aryl halides or triflates. Another report by Suzuki and Miyaura involves the Pd-catalysed reaction of arylboronic acids with aryl halides in an atmospheric pressure of carbon monoxide. ${ }^{333}$ All of these methods, however, have some drawbacks such as drastic conditions and toxic organotin reagents or carbon monoxide, etc. The reactions of organometallic reagents with aryl chlorides often proceed in low yields because of the addition of the organometallic reagent to the ketone to form tertiary alcohols. In this regard, Uemura reported the $\mathrm{Pd}\left(\mathrm{PPh}_{3}\right)_{4}$-catalysed reaction of acyl chlorides and sodium tetraphenylborate $\left(\mathrm{NaBPh}_{4}\right)$ to give the corresponding phenyl ketones, ${ }^{334}$ but only one phenyl ring from the borate complex was participating in the reaction. In order to address these problems, Bumagin and co-workers ${ }^{335}$ reported a phosphine-free $\mathrm{Pd}(\mathrm{OAc})_{2}$-catalysed acyldeboration of sodium tetraarylborates, and $\mathrm{PdCl}_{2}-$ catalysed reactions of arylboronic acids with acyl chlorides under aqueous as well as non-aqueous acetone conditions in the presence of a mild base $\left(\mathrm{Na}_{2} \mathrm{CO}_{3}\right)$. They found a transfer of all of the aryl groups of the sodium tetraarylborate to give 


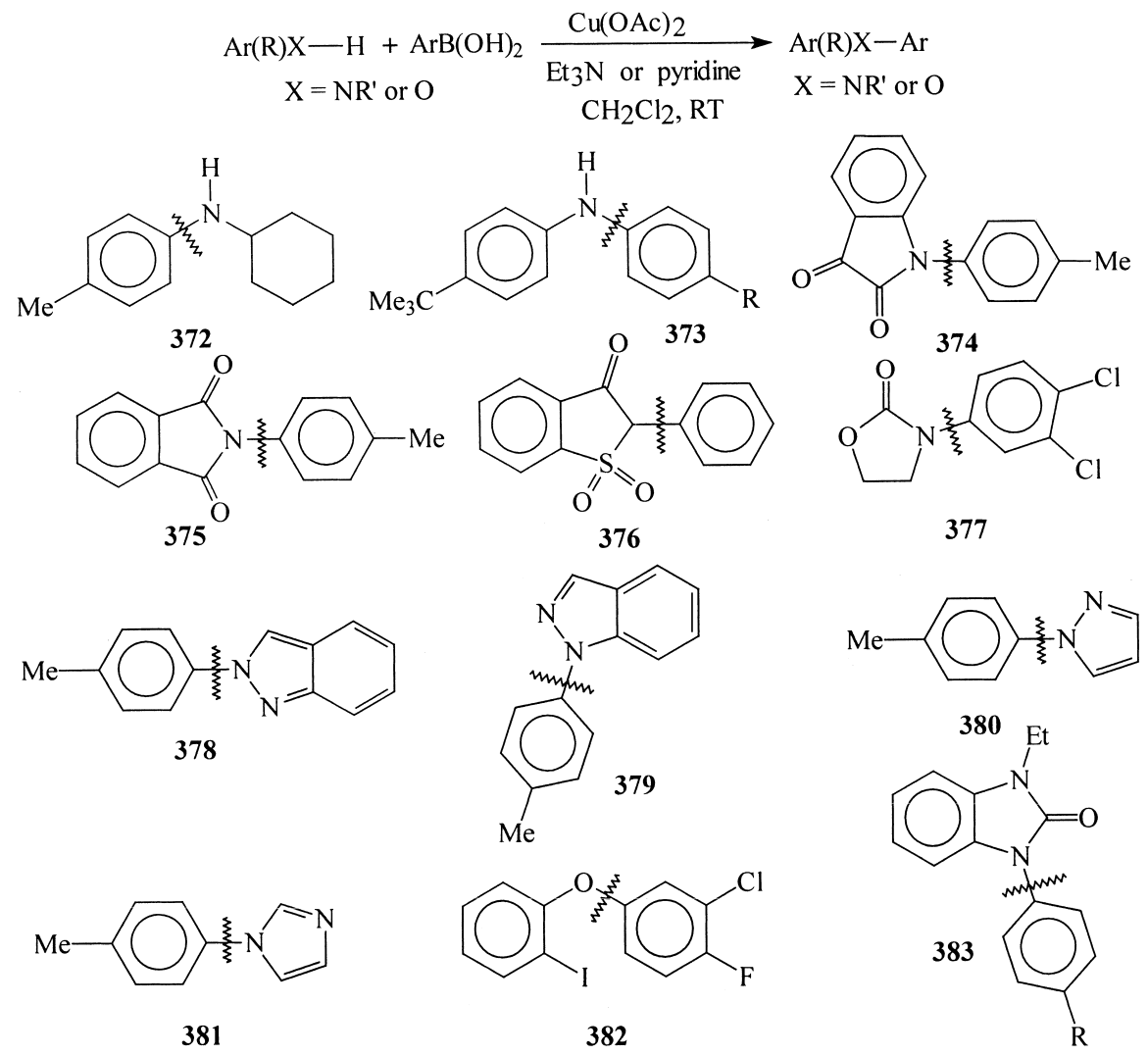

Figure 16. Some compounds prepared via a $\mathrm{Cu}$-catalysed $\mathrm{SM}$ type cross-coupling reaction.<smiles>CCOC(=O)C(N)Cc1cc(I)c(O)c(I)c1</smiles>

Scheme 156.

the corresponding ketones (Scheme 163). Along similar lines, Haddach and co-workers reported a Pd-catalysed coupling reaction of organoboronic acids with acid chlorides under anhydrous reaction conditions to give the diaryl ketones in moderate to good yields (Scheme 164). ${ }^{336}$

Castanet et al. synthesised the $\alpha$-pyridyl ketones 393a and

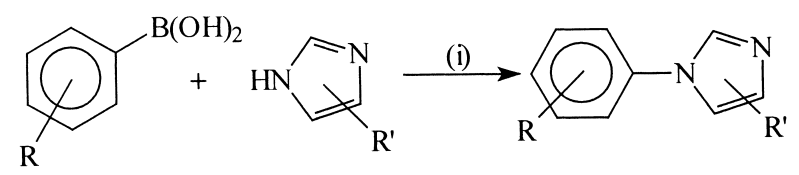

Scheme 157. (i) $[\mathrm{Cu}(\mathrm{OH}) \cdot \mathrm{TMEDA}]_{2} \mathrm{Cl}_{2}, \mathrm{CH}_{2} \mathrm{Cl}_{2}, \mathrm{O}_{2}$ or air, RT, overnight. 393b by using the $\mathrm{PdCl}_{2}\left(\mathrm{PCy}_{3}\right)_{2}$-catalysed carbonylative cross-coupling reactions of the pyridine halides and arylboronic acids under an atmospheric pressure of carbon monoxide. The yields and selectivity depend on the temperature and pressure of the carbon monoxide (Scheme 165). ${ }^{337}$

The cyclopropyl ketone moiety is present in a wide variety of marine natural products of different biological properties and cyclopropyl ketones are important compounds for mechanistic studies. In this connection, Deng and co-workers have reported a novel stereocontrolled synthesis of 1,2-trans-cyclopropyl ketones 394 via a Pd-catalysed SM type cross-coupling reaction of acid chlorides with chiral 

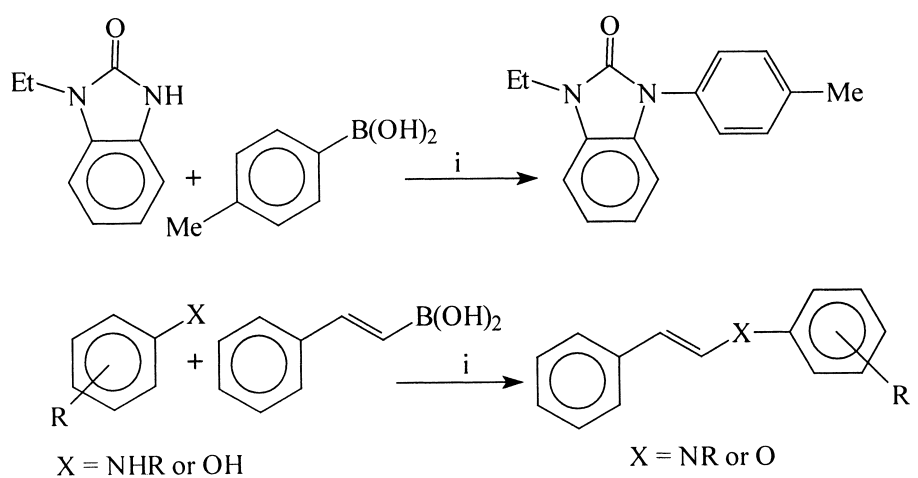

Scheme 158. (i) $\mathrm{Cu}(\mathrm{OAc})_{2}$, additive (1:1 equiv.), base (2 equiv.), $\mathrm{CH}_{2} \mathrm{Cl}_{2}, 4 \AA$ molecular sieves, $\mathrm{O}_{2}$, or air.<smiles>[R]c1ccc(Nc2ccc(C(C)C)cc2)c([R])c1</smiles>

Scheme 159. (i) $\mathrm{Cu}(\mathrm{OAc})_{2}$, myristic acid, 2,6-lutidine, air. cyclopropylboronic acids in the presence of $\mathrm{Ag}_{2} \mathrm{O}$ and $\mathrm{K}_{2} \mathrm{CO}_{3}$ in good yields (Scheme 166). ${ }^{338}$

Recently, Gooßen synthesised a variety of arylpropionic acid derivatives such as $\mathbf{3 9 5}$, which are present in several anti-inflammatory drugs, by using the $\mathrm{Pd}(\mathrm{OAc})_{2}$-catalysed

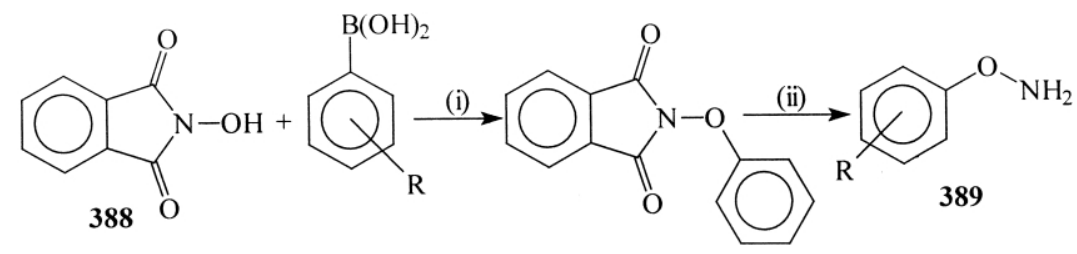

Scheme 160. (i) $\mathrm{Cu}(\mathrm{OAc})_{2}$ or $\mathrm{CuCl}_{2}$, pyridine or $\mathrm{Et}_{3} \mathrm{~N}, 4 \AA$ molecular sieves, $\mathrm{CH}_{2} \mathrm{Cl}_{2}, \mathrm{RT}, 24-48 \mathrm{~h}$. (ii) $\mathrm{NH}_{2} \mathrm{NH}_{2} \cdot \mathrm{H}_{2} \mathrm{O}, \mathrm{MeOH} / \mathrm{CHCl} 3, \mathrm{RT}, 12 \mathrm{~h}$.

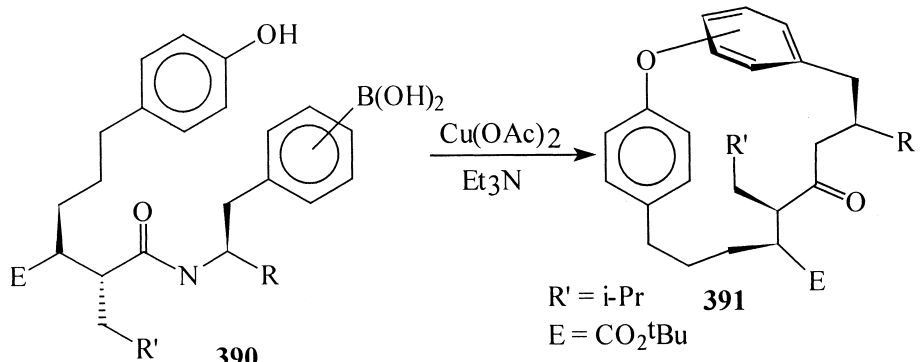

Scheme 161

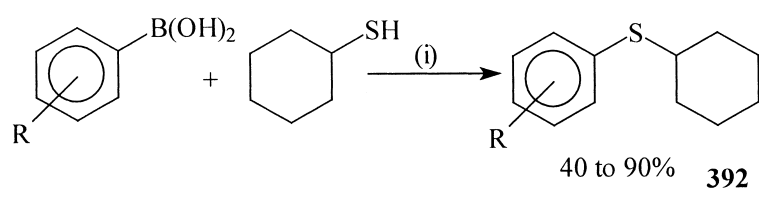

Scheme 162. (i) $\mathrm{Cu}(\mathrm{OAc})_{2}$, pyridine, $4 \AA$ molecular sieves, DMF.

$$
\begin{aligned}
& \mathrm{NaBAr}_{4}+4 \mathrm{RCOCl} \underset{\begin{array}{c}
\mathrm{Na}_{2} \mathrm{CO}_{3} \\
\text { acetone, } 20{ }^{0} \mathrm{C}
\end{array}}{\stackrel{\mathrm{Pd}(\mathrm{OAc})_{2}}{\longrightarrow}} 4 \text { ArCOR } 100 \% \\
& \mathrm{ArB}(\mathrm{OH})_{2}+\mathrm{PhCOCl} \underset{\begin{array}{c}
\mathrm{Na}_{2} \mathrm{CO}_{3} \\
\text { acetone } / \text { water }
\end{array}}{\stackrel{\mathrm{PdCl}_{2}}{\longrightarrow}} \text { PhCOAr to } 96 \% \\
& 20^{\circ} \mathrm{C}
\end{aligned}
$$

Scheme 163
SM cross-coupling reaction of arylboronic acids and pinacolboronates with $\alpha$-bromoesters in the presence of phosphine ligands and a base (Scheme 167). ${ }^{339}$ Gooßen and co-workers also synthesised diaryl and aryl/alkyl ketones from the reaction of boronic acids with carboxylic acids and anhydrides by using the same protocol (Scheme 168). ${ }^{340}$

\section{Rhodium- and nickel-catalysed reactions of arylboronic acids}

Along with Pd, several rhodium- and nickel-based catalysts have been used for the carbon-carbon bond formation reaction during the past few years. In this connection, Hayashi has reported the rhodium-catalysed asymmetric 1,4 -addition of boronic acids and triarylboranes to different types of unsaturated systems such as $\alpha, \beta$-unsaturated ketones, $\alpha, \beta$-unsaturated esters, 1-alkenylphosphonates, 


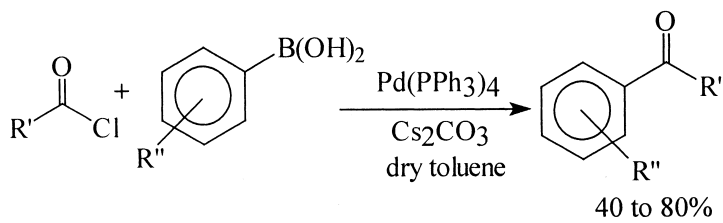

Scheme 164. nitroalkenes and 5,6-dihydro-2(1H)-pyridinones in the presence of chiral binaphthylphosphine ligands in good yields with high enantioselectivities. ${ }^{341,342}$ A few selected examples of these results are given in Schemes 169-173.

Maddaford and co-workers reported the simple $\mathrm{Pd}(\mathrm{OAc})_{2}-$ and $\mathrm{Rh}(\operatorname{cod})_{2} \mathrm{BF}_{4}$-catalysed $C$-arylations of the glycosides

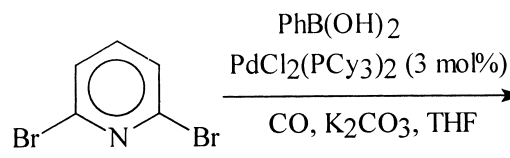

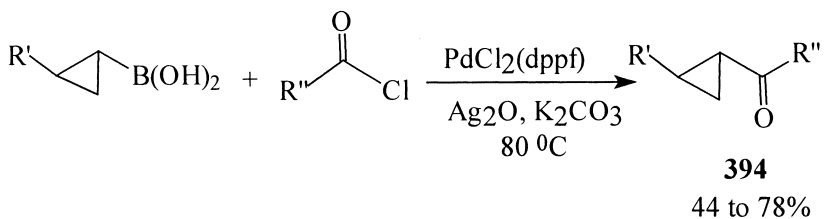

Scheme 166.

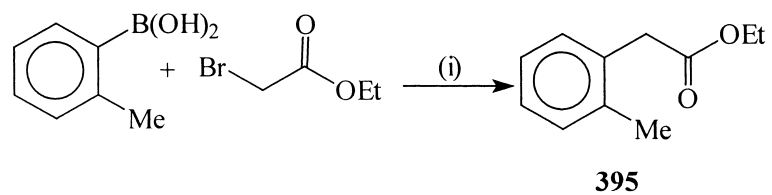

Scheme 167. (i) $\mathrm{Pd}(\mathrm{OAc})_{2}(3 \mathrm{~mol} \%), \mathrm{P}(\mathrm{Nap})_{3}(9 \mathrm{~mol} \%), \mathrm{K}_{3} \mathrm{PO}_{4}$, $\mathrm{THF} / \mathrm{H}_{2} \mathrm{O}, \mathrm{RT}, 16 \mathrm{~h}, 90 \%$.
396 and 398 (Schemes 174 and 175). ${ }^{343,344}$ The resulting C-arylglycosides 397 and 399 acts as inhibitors of carbohydrate processing enzymes and can be used as building blocks for the synthesis of C-arylglycopyranosides and other natural products.

Fürstner et al. demonstrated the rhodium-catalysed addition of aryl- and alkenylboronic acids to aldehydes in the presence of phosphine and sterically hindered $N$-heterocyclic carbene complex ligands such as $\mathbf{1 6}$ and 18 (Scheme 176). ${ }^{345}$ Along similar lines, Frost and co-workers have also reported the addition of arylboronic acids to aldehydes under optimised conditions by using $[\mathrm{RhCl}(\text { ethylene })]_{2}$ $\mathrm{RuCl}_{3} \cdot 3 \mathrm{H}_{2} \mathrm{O}$ and $[\mathrm{RhCl}(\mathrm{cod})]_{2}$ catalysts in the presence of the nitrogen-containing ligand $\mathbf{4 0 0}$ and counterions. They found improved results with the $[\mathrm{RhCl}(\mathrm{cod})]_{2}$ complex and a $\mathrm{PF}_{6}$ counterion (Scheme 177). ${ }^{346}$ The Miyaura and Batey groups also reported the use of rhodium catalysts for this reaction in the presence of phosphine ligands. ${ }^{347,348}$

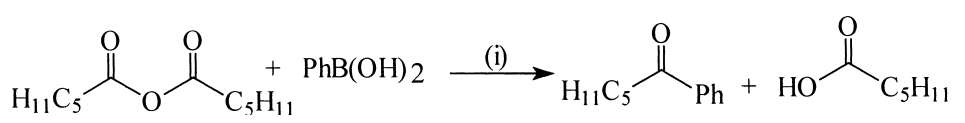

Scheme 168. (i) $\mathrm{Pd}(\mathrm{OAc})_{2}, \mathrm{PPh}_{3}, \mathrm{THF} / \mathrm{H}_{2} \mathrm{O}, 97 \%$.

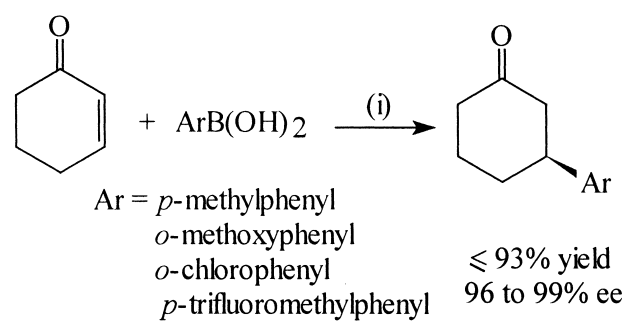

Scheme 169. (i) $\mathrm{Rh}(\mathrm{acac})\left(\mathrm{C}_{2} \mathrm{H}_{4}\right)_{2}(3 \mathrm{~mol} \%)$, (S)-binap (1 equiv. to $\left.\mathrm{Rh}\right)$, dioxane/water, $100^{\circ} \mathrm{C}$.
The $[\mathrm{Rh}(\operatorname{cod}) \mathrm{Cl}]_{2}$-catalysed reaction of heterocyclic alkynes $\mathbf{4 0 3}$ with arylboronic acids in the presence of water-soluble ligands such as $\mathbf{4 0 1}$ and $\mathbf{4 0 2}$ and sodium dodecylsulphate (SDS) and sodium carbonate as bases furnished the trisubstituted alkenes $\mathbf{4 0 4}$ in high regioselectivity as shown in Scheme $178 .{ }^{349}$

Recently, Uemura and co-workers discovered a $\mathrm{Ni}(\mathrm{acac})_{2^{-}}$ catalysed asymmetric cross-coupling reaction of allyl acetates with arylboronic acids in the presence of the 


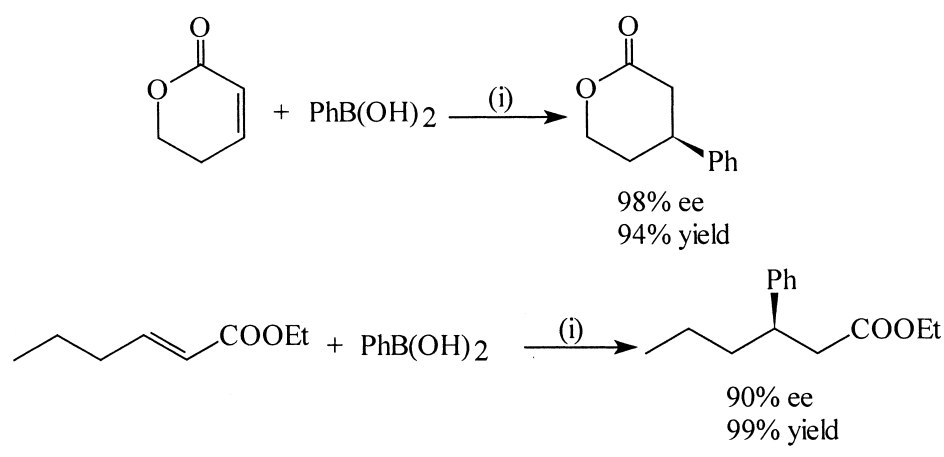

Scheme 170. (i) $\mathrm{Rh}(\mathrm{acac})\left(\mathrm{C}_{2} \mathrm{H}_{4}\right)_{2}(3 \mathrm{~mol} \%),(S)$-binap (1 equiv. to $\left.\mathrm{Rh}\right)$, dioxane/water, $100^{\circ} \mathrm{C}, 3 \mathrm{~h}$.

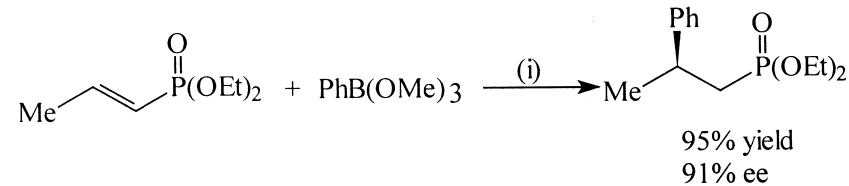

Scheme 171. (i) $\mathrm{Rh}(\mathrm{acac})\left(\mathrm{C}_{2} \mathrm{H}_{4}\right)_{2}(3 \mathrm{~mol} \%)$, (S)-binap, dioxane/water, $100^{\circ} \mathrm{C}, 3 \mathrm{~h}$.

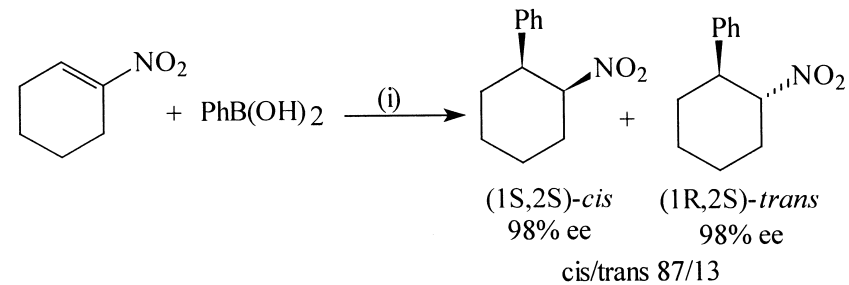

Scheme 172. (i) $\mathrm{Rh}(\mathrm{acac})\left(\mathrm{C}_{2} \mathrm{H}_{4}\right)_{2}(3 \mathrm{~mol} \%)$, (S)-binap, dioxane/water, $100^{\circ} \mathrm{C}, 3 \mathrm{~h}, 89 \%$.

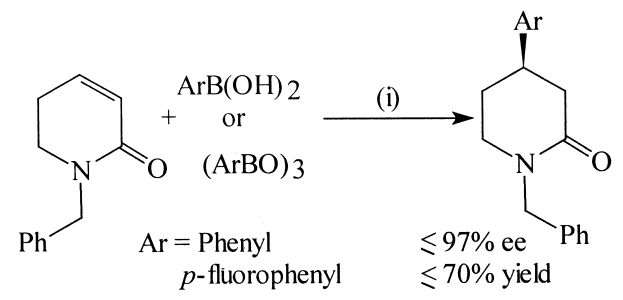

Scheme 173. (i) $\mathrm{Rh}(\mathrm{acac})\left(\mathrm{C}_{2} \mathrm{H}_{4}\right)_{2}(3 \mathrm{~mol} \%)$, (R)-binap, dioxane.<smiles>CC(=O)OCC#CCOC1C(OC(C)=O)C=COC1COC(C)=O</smiles>

Scheme 174. (i) $\mathrm{Pd}(\mathrm{OAc})_{2}(10 \mathrm{~mol} \%), \mathrm{MeCN}, \mathrm{RT}, 82 \%$. chiral oxazolinylferrocenylphosphine ligands $\mathbf{4 0 5}$ and 406 in good yields with moderate enantioselectivities (Scheme 179). ${ }^{350}$

\section{Conclusions and future prospects}

From this review, it is clear that the SM cross-coupling reaction is more user-friendly than other coupling reactions and is widely employed in the synthesis of various natural and non-natural products. This methodology has found extensive use in the preparation of several drug-like molecules. Many problems associated with the SM crosscoupling reaction have been addressed here. Various advances to overcome the problems associated with less reactive electrophiles such as aryl chlorides are discussed. There are some uncertainties, however, with regard to the selection of ligand, catalyst, solvent, base, additives, etc. An important aspect which require further attention is the lack of suitable methods for the preparation of boronic acids without the involvement of lithium reagents. Recently, some catalytic methods have been found to be useful to address this issue, thereby avoiding the sensitive lithiation reactions. ${ }^{351,352}$ Additional advances are likely to appear in the near future. Limited examples are available regarding the asymmetric SM cross-coupling reaction and it is hoped that more advances may come in the near future.

\section{Acknowledgements}

We thank the DST and CSIR, New Delhi for their financial support of our research programmes over the past few years. We also thank Professor M. K. Lakshman for sending the preprints of some of his papers.<smiles>COc1ccc([C@H]2CC(=O)C(OC(C)=O)C(COC(C)=O)C2)cc1</smiles>

Scheme 175. (i) $\left[\mathrm{Rh}(\operatorname{cod})_{2}\right] \mathrm{BF}_{4}(5 \mathrm{~mol} \%)$, dioxane/water, $100^{\circ} \mathrm{C} 4 \mathrm{~h}, 81 \%$. 


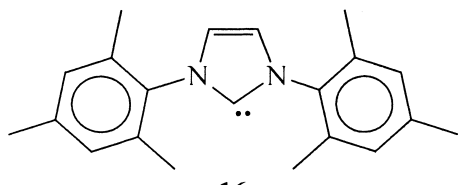

16<smiles></smiles>

18<smiles>CC(C)(C)[13CH2][C@@H]1COC(C(C)(C)C2=NC(C(C)(C)C)CO2)=N1</smiles>

400<smiles>COc1ccc(C=O)cc1</smiles>

Scheme 176. (i) $\mathrm{RhCl}_{3} \cdot 3 \mathrm{H}_{2} \mathrm{O}$ (1 mol\%), imidazolium chloride 18 ( $1 \mathrm{~mol} \%$ ), $\mathrm{NaOMe}$, DME, $80^{\circ} \mathrm{C}, 1 \mathrm{~h}, 79 \%$.

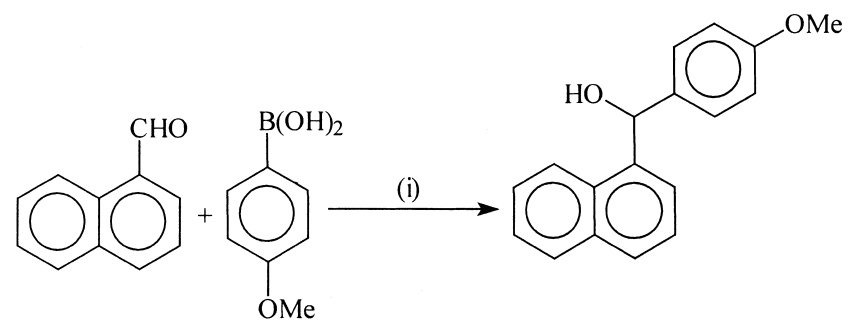

Scheme 177. (i) $[\mathrm{RhCl}(\mathrm{cod})]_{2}(0.5 \mathrm{~mol} \%), 400, \mathrm{PF}_{6}$ (counterion), dioxane, $80^{\circ} \mathrm{C}, 79 \%$.

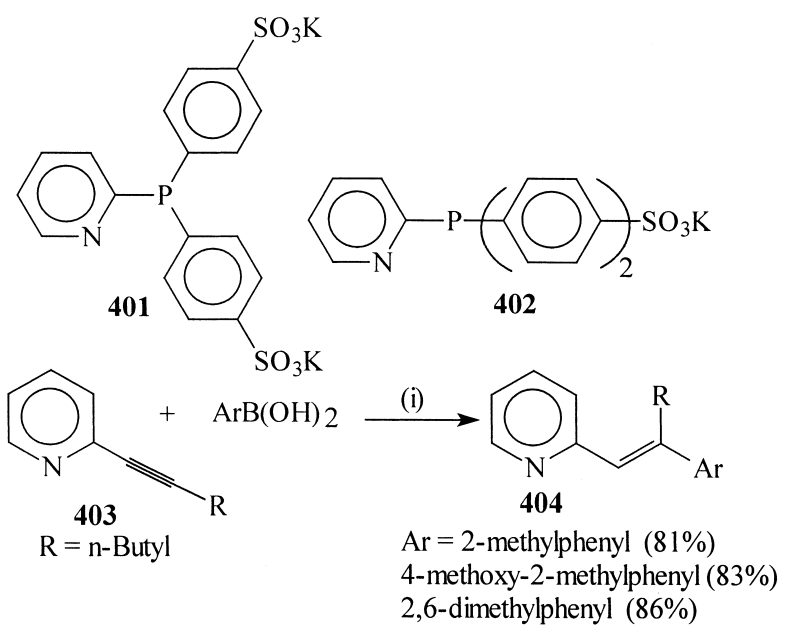

Scheme 178. (i) $[\mathrm{RhCl}(\operatorname{cod})]_{2}(2 \mathrm{~mol} \%)$, ligand $401(8 \mathrm{~mol} \%), \mathrm{Na}_{2} \mathrm{CO}_{3}$, sodium dodecylsulphate, $\mathrm{H}_{2} \mathrm{O}, 80^{\circ} \mathrm{C}, 1-3 \mathrm{~h}$.

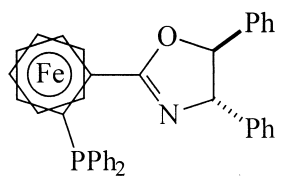

(S)-DIPOF 405

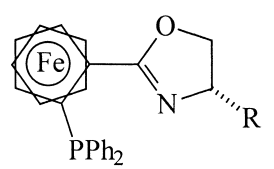

$\mathrm{R}=\mathrm{i}-\operatorname{Pr} 406$

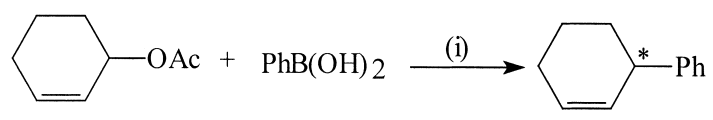

$\mathrm{ee}=50 \%$ yield $=81 \%$

Scheme 179. (i) $\mathrm{Ni}(\mathrm{acac})_{2}$, DIBAL-H, ligand 406, KOH, THF, reflux, $17 \mathrm{~h}$.

\section{References}

1. Miyaura, N.; Yanagi, T.; Suzuki, A. Synth. Commun. 1981, 11, 513.

2. Suzuki, A. Pure Appl. Chem. 1985, 57, 1749. Suzuki, A. Pure Appl. Chem. 1991, 63, 419.

3. Martin, A. R.; Yang, Y. Acta Chem. Scand. 1993, 47, 221.

4. Suzuki, A. Pure Appl. Chem. 1994, 66, 213.

5. Miyaura, N.; Suzuki, A. Chem. Rev. 1995, 95, 2457.

6. Stanforth, S. P. Tetrahedron 1998, 54, 263.

7. Miyaura, N. Advances in Metal-organic Chemistry; Libeskind, L. S., Ed.; Jai: London, 1998; Vol. 6, pp 187-243.

8. Suzuki, A. J. Organomet. Chem. 1999, 576, 147.

9. Suzuki, A. In Organoboranes for Syntheses. ACS Symposium Series 783; Ramachandran, P. V., Brown, H. C., Eds.; American Chemical Society: Washington, DC, 2001; pp 80-93.

10. Ganesan, A. Drug Discov. Today 2001, 6, 238.

11. Darses, S.; Jeffery, T.; Genet, J.-P.; Brayer, J.-L.; Demoute, J. P. Tetrahedron Lett. 1996, 37, 3857. Sengupta, S.; Bhattacharyya, S. J. Org. Chem. 1997, 62, 3405.

12. Schlüter, A. D. J. Polym. Sci. Part A: Polym. Chem. 2001, 39, 1533.

13. Matteson, D. S. The Chemistry of the Metal-Carbon Bond; Hartley, F. R., Patai, S., Eds.; Wiley: New York, 1987; Vol. 4, pp 307-499.

14. Faraoni, M. B.; Koll, L. C.; Mandolesi, S. D.; Zúñiga, A. E.; Podestá, J. C. J. Organomet. Chem. 2000, 613, 236.

15. Ishiyama, T.; Matsuda, N.; Miyaura, N.; Suzuki, A. J. Am. Chem. Soc. 1993, 115, 11018.

16. Ishiyama, T.; Murata, M.; Miyaura, N. J. Org. Chem. 1995, 60, 7508 .

17. Ishiyama, T.; Ishida, K.; Miyaura, N. Tetrahedron 2001, 57, 9813.

18. Willis, D. M.; Strongin, R. M. Tetrahedron Lett. 2000, 41, 8683.

19. Chen, H.; Schlecht, S.; Semple, T. C.; Hartwig, J. F. Science 2000, 287, 1995.

20. Murata, M.; Oyama, T.; Watanabe, S.; Masuda, Y. J. Org. Chem. 2000, 65, 164

21. Davies, M. W.; Wybrow, R. A. J.; Johnson, C. N.; Harrity, J. P. A. Chem. Commun. 2001, 1558.

22. Yang, F.-Y.; Cheng, C.-H. J. Am. Chem. Soc. 2001, 123, 761.

23. Caron, S.; Hawkins, J. M. J. Org. Chem. 1998, 63, 2054.

24. Kristensen, J.; Lysén, M.; Vedso, P.; Begtrup, M. Org. Lett. 2001, 3, 1435. 
25. Baudoin, O.; Guénard, D.; Guéritte, F. J. Org. Chem. 2000, 65, 9268.

26. Falck, J. R.; Bondlela, M.; Venkataraman, S. K.; Srinivas, D. J. Org. Chem. 2001, 66, 7148.

27. Herrmann, W. A.; Reisinger, C.-P.; Spiegler, M. J. Organomet. Chem. 1998, 557, 93.

28. Weskamp, T.; Böhm, V. P. W.; Herrmann, W. A. J. Organomet. Chem. 1999, 585, 348.

29. Böhm, V. P. W.; Gstöttmayr, C. W. K.; Weskamp, T.; Herrmann, W. A. J. Organomet. Chem. 2000, 595, 186.

30. Zhang, C.; Huang, J.; Trudell, M. L.; Nolan, S. P. J. Org. Chem. 1999, 64, 3804.

31. Zhang, C.; Trudell, M. L. Tetrahedron Lett. 2000, 41, 595.

32. Shen, W. Tetrahedron Lett. 1997, 38, 5575.

33. Fürstner, A.; Leitner, A. Synlett 2001, 290.

34. Littke, A. F.; Fu, G. C. Angew. Chem., Int. Ed. 1998, 37, 3387.

35. (a) Littke, A. F.; Dai, C.; Fu, G. C. J. Am. Chem. Soc. 2000 , 122, 4020. (b) Netherton, M. R.; Fu, G. C. Org. Lett. 2001, 3, 4295.

36. Liu, S.-Y.; Choi, M. J.; Fu, G. C. J. Chem. Soc., Chem. Commun. 2001, 2408.

37. Wolfe, J. P.; Singer, R. A.; Yang, B. H.; Buchwald, S. L. J. Am. Chem. Soc. 1999, 121, 9550.

38. Old, D. W.; Wolfe, J. P.; Buchwald, S. L. J. Am. Chem. Soc. 1998, 120, 9722.

39. Wolfe, J. P.; Buchwald, S. L. Angew. Chem., Int. Ed. 1999, $38,2413$.

40. Kočovský, P.; Vyskočil, S.; Císarová, I.; Sejbal, J.; Tišlerová, I.; Smrčina, M.; Lloyd-Jones, G. C.; Stephen, S. C.; Butts, C. P.; Murray, M.; Langer, V. J. Am. Chem. Soc. 1999, 121, 7714.

41. Bei, X.; Turner, H. W.; Weinberg, W. H.; Guram, A. S. J. Org. Chem. 1999, 64, 6797.

42. Bei, X.; Crevier, T.; Guram, A. S.; Jandeleit, B.; Powers, T. S.; Turner, H. W.; Uno, T.; Weinberg, W. H. Tetrahedron Lett. 1999, 40, 3855.

43. Lohse, O.; Thevenin, P.; Waldvogel, E. Synlett 1999, 45.

44. Maes, B. U. W.; R'kyek, O. R.; Košmrlj, J.; Lemière, G. L. F.; Esmans, E.; Rozenski, J.; Dommisse, R. A.; Haemers, A. Tetrahedron 2001, 57, 1323.

45. Guery, S.; Parrot, I.; Rival, Y.; Wermuth, C. G. Tetrahedron Lett. 2001, 42, 2115.

46. Cooke, G.; de Cremiers, H. A.; Rotello, V. M.; Tarbit, B.; Vanderstraeten, P. E. Tetrahedron 2001, 57, 2787.

47. Beller, M.; Fischer, H.; Herrmann, W. A.; Öfele, K.; Brossmer, C. Angew. Chem., Int. Ed. Engl. 1995, 34, 1848.

48. Albisson, D. A.; Bedford, R. B.; Lawrence, S. E.; Scully, P. N. Chem. Commun. 1998, 2095.

49. Bedford, R. B.; Welch, S. L. Chem. Commun. 2001, 129.

50. Bedford, R. B.; Draper, S. M.; Scully, P. N.; Welch, S. L. New. J. Chem. 2000, 24, 745.

51. Bedford, R. B.; Cazin, C. S. J. Chem. Commun. 2001, 1540.

52. Weissman, H.; Milstein, D. Chem. Commun. 1999, 1901.

53. Alonso, D. A.; Nájera, C.; Pacheco, M. C. Org. Lett. 2000, 2 , 1823.

54. Zim, D.; Gruber, A. S.; Ebeling, G.; Dupont, J.; Monteiro, A. L. Org. Lett. 2000, 2, 2881.

55. Zapf, A.; Beller, M. Chem. Eur. J. 2000, 6, 1830.

56. Andreu, M. G.; Zapf, A.; Beller, M. Chem. Commun. 2000, 2475.

57. Feuerstein, M.; Laurenti, D.; Bougeant, C.; Doucet, H.; Santelli, M. Chem. Commun. 2001, 325.
58. Feuerstein, M.; Laurenti, D.; Doucet, H.; Santelli, M. Synthesis 2001, 2320.

59. Feuerstein, M.; Doucet, H.; Santelli, M. Tetrahedron Lett. 2001, 42, 6667.

60. Feuerstein, M.; Doucet, H.; Santelli, M. Tetrahedron Lett. 2001, 42, 5659.

61. Feuerstein, M.; Doucet, H.; Santelli, M. Synlett 2001, 1458.

62. Saito, S.; Sakai, M.; Miyaura, N. Tetrahedron Lett. 1996, 37, 2993.

63. Saito, S.; Oh-tani, S.; Miyaura, N. J. Org. Chem. 1997, 62, 8024.

64. Indolese, A. F. Tetrahedron Lett. 1997, 38, 3513.

65. Inada, K.; Miyaura, N. Tetrahedron 2000, 56, 8657.

66. Leadbeater, N. E.; Resouly, S. M. Tetrahedron 1999, 55, 11889.

67. Griffiths, C.; Leadbeater, N. E. Tetrahedron Lett. 2000, 41, 2487.

68. Lipshutz, B. H.; Sclafani, J. A.; Blomgren, P. A. Tetrahedron 2000, 56, 2139.

69. Percec, V.; Bae, J.-Y.; Hill, D. H. J. Org. Chem. 1995, 60, 1060.

70. Kobayashi, Y.; Mizojiri, R. Tetrahedron Lett. 1996, 37, 8531.

71. Zim, D.; Lando, V. R.; Dupont, J.; Montiero, A. L. Org. Lett. 2001, 3, 3049.

72. Genêt, J.-P.; Savignac, M. J. Organomet. Chem. 1999, 576, 305.

73. Dibowski, H.; Schmidichen, F. P. Tetrahedron 1995, 51, 2325.

74. Paetzold, E.; Oehme, G. J. Mol. Catal. A: Chem. 2000, 152, 69.

75. Genêt, J.-P.; Lindquist, A.; Blart, E.; Mouries, V.; Savignac, M.; Vaultier, M. Tetrahedron Lett. 1995, 36, 1443.

76. Galland, J.-C.; Savignac, M.; Genêt, J.-P. Tetrahedron Lett. 1999, 40, 2323.

77. Dupuis, C.; Adiey, K.; Charruault, L.; Michelet, V.; Savignac, M.; Genêt, J.-P. Tetrahedron Lett. 2001, 42, 6523.

78. Gelpke, A. E. S.; Veerman, J. J. N.; Goedheijt, M. S.; Kamer, P. C. J.; van Leeuwen, P. W. N. M.; Hiemstra, H. Tetrahedron 1999, 55, 6657.

79. Casalnuovo, A. L.; Calabrese, J. C. J. Am. Chem. Soc. 1990, $112,4324$.

80. Beller, M.; Krauter, J. G. E.; Zapf, A. Angew. Chem., Int. Ed. Engl. 1997, 36, 772.

81. Shaughnessy, K. H.; Booth, R. S. Org. Lett. 2001, 3, 2757.

82. Kabalka, G. W.; Namboodiri, V.; Wang, L. Chem. Commun. 2001, 775 .

83. Zim, D.; Monteiro, A. L.; Dupont, J. Tetrahedron Lett. 2000, 41, 8199 .

84. Bumagin, N. A.; Bykov, V. V. Tetrahedron 1997, 53, 14437.

85. Campi, E. M.; Jackson, W. R.; Marcuccio, S. M.; Naeslund, C. G. M. J. Chem. Soc., Chem. Commun. 1994, 2395.

86. LeBlond, C. R.; Andrews, A. T.; Sun, Y.; Sowa, Jr. J. R. Org. Lett. 2001, 3, 1555.

87. Grasa, G. A.; Hillier, A. C.; Nolan, S. P. Org. Lett. 2001, 3, 1077.

88. Bussolari, J. C.; Rehborn, D. C. Org. Lett. 1999, 1, 965.

89. Badone, D.; Baroni, M.; Cardamone, R.; Ielmini, A.; Guzzi, U. J. Org. Chem. 1997, 62, 7170.

90. Hesse, S.; Kirsch, G. Synthesis 2001, 755.

91. Villemin, D.; Gómez-Escalonilla, M. J.; Saint-Clair, J.-F. Tetrahedron Lett. 2001, 42, 635.

92. Kabalka, G. W.; Pagni, R. M.; Hair, C. M. Org. Lett. 1999, 1, 1423. 
93. Kabalka, G. W.; Pagni, R. M.; Wang, L.; Namboodiri, V.; Hair, C. M. Green Chem. 2000, 2, 120.

94. Larhed, M.; Hallberg, A. Drug Discov. Today 2001, 6, 406.

95. Schaal, W.; Karlsson, A.; Ahlsén, G.; Lindberg, J.; Andersson, H. O.; Danielson, U. H.; Classon, B.; Unge, T.; Samuelsson, B.; Hultén, J.; Hallberg, A.; Karlén, A. J. Med. Chem. 2001, 44, 155.

96. Larhed, M.; Lindeberg, G.; Hallberg, A. Tetrahedron Lett. 1996, 37, 8219

97. Combs, A. P.; Saubern, S.; Rafalski, M.; Lam, P. Y. S. Tetrahedron Lett. 1999, 40, 1623.

98. Alterman, M.; Andersson, H. O.; Garg, N.; Ahlsén, G.; Lövgren, S.; Classon, B.; Danielson, U. H.; Kvarnström, I.; Vrang, L.; Unge, T.; Samuelsson, B.; Hallberg, A. J. Med. Chem. 1999, 42, 3835.

99. Mathews, C. J.; Smith, P. J.; Welton, T. Chem. Commun. 2000, 1249.

100. Nielsen, S. F.; Peters, D.; Axelsson, O. Synth. Commun. 2000, 30, 3501 .

101. Mubofu, E. B.; Clark, J. H.; Macquarrie, D. J. Green Chem. 2001, 3, 23 .

102. Varma, R. S.; Naicker, K. P. Tetrahedron Lett. 1999, 40, 439.

103. Varma, R. S.; Naicker, K. P. Green Chem. 1999, 1, 247.

104. Reetz, M. T.; Breinbauer, R.; Wanninger, K. Tetrahedron Lett. 1996, 37, 4499.

105. Li, Y.; Hong, X. M.; Collard, D. M.; EI-Sayed, M. A. Org. Lett. 2000, 2, 2385.

106. Blettner, C. G.; König, W. A.; Stenzel, W.; Schotten, T. Synlett 1998, 295.

107. Blettner, C. G.; König, W. A.; Stenzel, W.; Schotten, T. J. Org. Chem. 1999, 64, 3885.

108. Blettner, C. G.; König, W. A.; Rühter, G.; Stenzel, W.; Schotten, T. Synlett 1999, 307.

109. Namboodiri, V. V.; Varma, R. S. Green Chem. 2001, 3, 146.

110. Uozumi, Y.; Danjo, H.; Hayashi, T. J. Org. Chem. 1999, 64, 3384.

111. Schneider, S.; Bannwarth, W. Helv. Chim. Acta 2001, 84, 735.

112. Schüster, T.; Göbel, M. W. Synlett 1999, 966.

113. Nelson, S. G.; Hilfiker, M. A. Org. Lett. 1999, 1, 1379.

114. Johnson, J. A.; Sames, D. J. Am. Chem. Soc. 2000, 122, 6321.

115. Chaumeil, H.; Signorella, S.; Drian, C. L. Tetrahedron 2000, $56,9655$.

116. Kotharé, M. A.; Ohkanda, J.; Lockman, J. W.; Qian, Y.; Blaskovich, M. A.; Sebti, S. M.; Hamilton, A. D. Tetrahedron 2000, 56, 9833.

117. Dyer, U. C.; Shapland, P. D.; Tiffin, P. D. Tetrahedron Lett. 2001, 42, 1765.

118. Baillie, C.; Chen, W.; Xiao, J. Tetrahedron Lett. 2001, 42, 9085.

119. Beletskaya, I. P.; Tsvetkov, A. V.; Latyshev, G. V.; Tafeenko, V. A.; Lukashev, N. V. J. Organomet. Chem. 2001, 637, 653.

120. Zhuravel, M. A.; Nguyen, S. T. Tetrahedron Lett. 2001, 42, 7925.

121. Lehmler, H.-J.; Robertson, L. W. Chemosphere 2001, 45, 137.

122. Lehmler, H.-J.; Robertson, L. W. Chemosphere 2001, 45, 1119.

123. Sugimori, T.; Okamoto, S.; Kotoh, N.; Handa, M.; Kasuga, K. Chem. Lett. 2000, 1200.

124. Mamane, V.; Riant, O. Tetrahedron 2001, 57, 2555.
125. Dirk, S. M.; Price, Jr. D. W.; Chanteau, S.; Kosynkin, D. V.; Tour, J. M. Tetrahedron 2001, 57, 5109.

126. Kotha, S.; Lahiri, K.; Sreenivasachary, N. Synthesis 2001, 1932.

127. Kotha, S.; Ghosh, A. K. Synlett 2002, 451.

128. Johnson, C. N.; Stemp, G.; Anand, N.; Stephen, S. C.; Gallagher, T. Synlett 1998, 1025.

129. Lee, C.-W.; Chung, Y. J. Tetrahedron Lett. 2000, 41, 3423.

130. Lee, C.-W.; Oh, K. S.; Kim, K. S.; Ahn, K. H. Org. Lett. 2000, 2, 1213.

131. Revesz, L.; Bonne, F.; Makavou, P. Tetrahedron Lett. 1998, $39,5171$.

132. Mello, J. V.; Finney, N. S. Org. Lett. 2001, 3, 4263.

133. Karig, G.; Spencer, J. A.; Gallagher, T. Org. Lett. 2001, 3, 835.

134. Morris, G. A.; Nguyen, S. T. Tetrahedron Lett. 2001, 42, 2093.

135. Gong, Y.; Pauls, H. W. Synlett 2000, 829.

136. Jones, K.; Keenan, M.; Hibbert, F. Synlett 1996, 509.

137. Aboul-Fadl, T.; Löber, S.; Gmeiner, P. Synthesis 2000, 1727.

138. Wang, X.-J.; Tan, J.; Grozinger, K. Tetrahedron Lett. 2000, $41,4713$.

139. Aldous, D. J.; Bower, S.; Moorcroft, N.; Todd, M. Synlett 2001, 150.

140. Kromann, H.; Sløk, F. A.; Johansen, T. N.; KrogsgaardLarsen, P. Tetrahedron 2001, 57, 2195.

141. Chi, S. M.; Choi, J.-K.; Yum, E. K.; Chi, D. Y. Tetrahedron Lett. 2000, 41, 919.

142. Liu, Y.; Gribble, G. W. Tetrahedron Lett. 2000, 41, 8717.

143. Collot, V.; Bovy, P. R.; Rault, S. Tetrahedron Lett. 2000, 41, 9053.

144. Tokuyama, H.; Kaburagi, Y.; Chen, X.; Fukuyama, T. Synthesis 2000, 429.

145. Merlic, C. A.; You, Y.; McInnes, D. M.; Zechman, A. L.; Miller, M. M.; Deng, Q. Tetrahedron 2001, 57, 5199.

146. Wendeborn, S.; Winkler, T.; Foisy, I. Tetrahedron Lett. 2000, $41,6387$.

147. Deprets, S.; Kirsch, G. Eur. J. Org. Chem. 2000, 1353.

148. (a) Lakshman, M. K.; Hilmer, J. H.; Martin, J. Q.; Keeler, J. C.; Dinh, Y. Q. V.; Ngassa, F. N.; Russon, L. M. J. Am. Chem. Soc. 2001, 123, 7779. (b) Lakshman, M. K.; Keeler, J. C.; Hilmer, J. H.; Martin, J. Q. J. Am. Chem. Soc. 1999 , 121,6090

149. Ding, S.; Gray, N. S.; Ding, Q.; Schultz, P. G. Tetrahedron Lett. 2001, 42, 8751.

150. Havelková, M.; Dvořák, D.; Hocek, M. Synthesis 2001, 1704.

151. McClure, M. S.; Glover, B.; McSorley, E.; Millar, A.; Osterhout, M. H.; Roschangar, F. Org. Lett. 2001, 3, 1677.

152. McClure, M. S.; Roschangar, F.; Hodson, S. J.; Millar, A.; Osterhout, M. H. Synthesis 2001, 1681.

153. Blake, A. J.; Cooke, P. A.; Doyle, K. J.; Gair, S.; Simpkins, N. S. Tetrahedron Lett. 1998, 39, 9093.

154. Dietrich-Buchecker, C.; Jimenez, M. C.; Sauvage, J.-P. Tetrahedron Lett. 1999, 40, 3395.

155. Belfrekh, N.; Dietrich-Buchecker, C.; Sauvage, J.-P. Tetrahedron Lett. 2001, 42, 2779.

156. Taylor, P. N.; O’Connell, M. J.; McNeill, L. A.; Hall, M. J.; Aplin, R. T.; Anderson, H. L. Angew. Chem., Int. Ed. 2000, 39, 3456.

157. Zhang, F.-J.; Cortez, C.; Harvey, R. G. J. Org. Chem. 2000, 65, 3952.

158. Albrecht, M.; Schneider, M. Synthesis 2000, 1557.

159. Walsh, C. J.; Mandal, B. K. Chem. Mater. 2001, 13, 2472. 
160. Beyerlein, T.; Tieke, B. Macromol. Rapid Commun. 2000, 21, 182.

161. Smet, M.; Metten, B.; Dehaen, W. Tetrahedron Lett. 2001, $42,6527$.

162. Oriol, L.; Piñol, M.; Serrano, J. L.; Martínez, C.; Alcalá, R.; Cases, R.; Sánchez, C. Polymer 2001, 42, 2737.

163. Wasgindt, M.; Klemm, E. Synth. Commun. 1999, 29, 103.

164. Manickam, G.; Schlüter, A. D. Synthesis 2000, 442.

165. Yan, Y.-Y.; Widhalm, M. Tetrahedron: Asymmetry 1998, 9, 3607.

166. Huang, W.-S.; Pu, L. Tetrahedron Lett. 2000, 41, 145.

167. Yu, H.-B.; Hu, Q.-S.; Pu, L. Tetrahedron Lett. 2000, 41, 1681.

168. Tsubaki, K.; Tanaka, H.; Furuta, T.; Kinoshita, T.; Fuji, K. Tetrahedron Lett. 2000, 41, 6089.

169. Kasák, P.; Mikláš, R.; Putala, M. J. Organomet. Chem. 2001, 637, 318

170. Hua, D. H.; McGill, J. W.; Ueda, M.; Stephany, H. A. J. Organomet. Chem. 2001, 637, 832.

171. Park, J.-W.; Ediger, M. D.; Green, M. M. J. Am. Chem. Soc. 2001, 123, 49.

172. Brunner, H.; Olschewski, G.; Nuber, B. Synlett 1999, 429.

173. Lacey, P. M.; McDonnell, C. M.; Guiry, P. J. Tetrahedron Lett. 2000, 41, 2475.

174. Tucker, S. C.; Brown, J. M.; Oakes, J.; Thornthwaite, D. Tetrahedron 2001, 57, 2545.

175. Tellenbröker, J.; Kuck, D. Eur. J. Org. Chem. 2001, 1483.

176. Xu, G.; Sygula, A.; Marcinow, Z.; Rabideau, P. W. Tetrahedron Lett. 2000, 41, 9931.

177. Lahti, P. M.; Liao, Y.; Julier, M.; Palacio, F. Synth. Met. 2001, 122, 485.

178. Schomaker, J. M.; Delia, T. J. J. Org. Chem. 2001, 66, 7125.

179. (a) Kotha, S.; Lahiri, K.; Kashinath, D. Unpublished results. (b) Lahiri, K. Ph.D. Thesis, IIT-Bombay, 2002.

180. Vaz, B.; Alvarez, R.; Nieto, M.; Paniello, A. I.; de Lera, A. R. Tetrahedron Lett. 2001, 42, 7409.

181. Muzzi, C. M.; Medforth, C. J.; Voss, L.; Cancilla, M.; Lebrilla, C.; Ma, J.-G.; Shelnutt, J. A.; Smith, K. M. Tetrahedron Lett. 1999, 40, 6159.

182. Tse, M. K.; Zhou, Z.-Y.; Mak, T. C. W.; Chan, K. S. Tetrahedron 2000, 56, 7779.

183. Yu, L.; Lindsey, J. S. Tetrahedron 2001, 57, 9285.

184. Aratani, N.; Osuka, A. Org. Lett. 2001, 3, 4213.

185. Dai, W.-M.; Mak, W. L. Tetrahedron Lett. 2000, 41, 10277.

186. Charas, A.; Morgado, J.; Martinho, J. M. G.; Alcácer, L.; Cacialli, F. Synth. Met. 2002, 127, 251.

187. Pereira, R.; Iglesias, B.; de Lera, A. R. Tetrahedron 2001, 57, 7871.

188. Kiryanov, A. A.; Seed, A. J.; Sampson, P. Tetrahedron Lett. 2001, 42, 8797.

189. Collis, G. E.; Burrell, A. K.; Officer, D. L. Tetrahedron Lett. 2001, 42, 8733.

190. Effenberger, F.; Grube, G. Synthesis 1998, 1372.

191. Krämer, C. S.; Zeitler, K.; Müller, T. J. J. Tetrahedron Lett. 2001, 42, 8619.

192. Kotha, S.; Chakraborty, K.; Brahmachary, E. Synlett 1999, 1621.

193. (a) Nicolaou, K. C.; Li, H.; Boddy, C. N. C.; Ramanjulu, J. M.; Yue, T.-Y.; Natarajan, S.; Chu, X.-J.; Bräse, S.; Rübsam, F. Chem. Eur. J. 1999, 5, 2584. (b) Nicolaou, K. C.; Boddy, C. N. C.; Li, H.; Koumbis, A. E.; Hughes, R.; Natarajan, S.; Jain, N. F.; Ramanjulu, J. M.; Bräse, S.; Soloman, M. E. Chem. Eur. J. 1999, 5, 2602. (c) Nicolaou,
K. C.; Koumbis, A. E.; Takayanagi, M.; Natarajan, S.; Jain, N. F.; Bando, T.; Li, H.; Hughes, R. Chem. Eur. J. 1999, 5, 2622. (d) Nicolaou, K. C.; Mitchell, H. J.; Jain, N. F.; Bando, T.; Hughes, R.; Winssinger, N.; Natarajan, S.; Koumbis, A. E. Chem. Eur. J. 1999, 5, 2648.

194. Kamikawa, K.; Watanabe, T.; Daimon, A.; Uemura, M. Tetrahedron 2000, 56, 2325.

195. Yin, J.; Buchwald, S. L. J. Am. Chem. Soc. 2000, 122, 12051.

196. Cammidge, A. N.; Crépy, K. Chem. Commun. 2000, 1723.

197. Bolm, C.; Hildebrand, J. P.; Muñiz, K.; Hermanns, N. Angew. Chem., Int. Ed. 2001, 40, 3284.

198. Lloyd-Williams, P.; Giralt, E. Chem. Soc. Rev. 2001, 30, 145.

199. Kamikawa, K.; Uemura, M. Synlett 2000, 938.

200. Steele, M.; Watkinson, M.; Whiting, A. J. Chem. Soc., Perkin Trans. 1 2001, 588.

201. Cho, S. Y.; Shibasaki, M. Tetrahedron: Asymmetry 1998, 9 , 3751.

202. Kimura, M.; Shiba, T.; Muto, T.; Hanabusa, K.; Shirai, H. Tetrahedron Lett. 2000, 41, 6809.

203. Gong, L.-Z.; Pu, L. Tetrahedron Lett. 2001, 42, 7337.

204. Turrin, C.-O.; Chiffre, J.; Daran, J.-C.; de Montauzon, D.; Caminade, A.-M.; Manoury, E.; Balavoine, G.; Majoral, J.-P. Tetrahedron 2001, 57, 2521.

205. Zhang, J.; Aszodi, J.; Chartier, C.; L'hermite, N.; Weston, J. Tetrahedron Lett. 2001, 42, 6683.

206. Satoh, Y.; Gude, C.; Chan, K.; Firooznia, F. Tetrahedron Lett. 1997, 38, 7645.

207. Firooznia, F.; Gude, C.; Chan, K.; Satoh, Y. Tetrahedron Lett. 1998, 39, 3985.

208. Firooznia, F.; Gude, C.; Chan, K.; Marcopulos, N.; Satoh, Y. Tetrahedron Lett. 1999, 40, 213.

209. Nakamura, H.; Fujiwara, M.; Yamamoto, Y. Bull. Chem. Soc. Jpn 2000, 73, 231.

210. (a) Collier, P. N.; Patel, I.; Taylor, R. J. K. Tetrahedron Lett. 2001, 42, 5953. (b) Campbell, A. D.; Raynham, T. M.; Taylor, R. J. K. Tetrahedron Lett. 1999, 40, 5263.

211. Collier, P. N.; Campbell, A. D.; Patel, I.; Taylor, R. J. K. Tetrahedron Lett. 2000, 41, 7115.

212. Isaac, M.; Slassi, A.; Silva, K. D.; Xin, T. Tetrahedron Lett. 2001, 42, 2957.

213. Hsiao, C. K.; Hangauer, D. G. Synthesis 1998, 1043.

214. Kabalka, G. W.; Das, B. C.; Das, S. Tetrahedron Lett. 2001, 42,7145 .

215. McKenna, J. M.; Moliterni, J.; Qiao, Y. Tetrahedron Lett. 2001, 42, 5797.

216. Collet, S.; Danion-Bougot, R.; Danion, D. Synth. Commun. 2001, 31, 249.

217. Kotha, S.; Halder, S.; Lahiri, K. Synthesis 2002, 339.

218. Kotha, S.; Behera, M.; Kumar, R. V. Bioorg. Med. Chem. Lett. 2002, 12, 105.

219. Kotha, S.; Ghosh, A. Unpublished results.

220. Kotha, S.; Lahiri, K. Bioorg. Med. Chem. Lett. 2001, 11, 2887.

221. Shen, W. Synlett 2000, 737.

222. Bauer, A.; Miller, M. W.; Vice, S. F.; McCombie, S. W. Synlett 2001, 254.

223. Uenishi, J.-I.; Beau, J.-M.; Armstrong, R. W.; Kishi, Y. J. Am. Chem. Soc. 1987, 109, 4756.

224. Roush, W. R.; Reilly, M. L.; Kayama, K.; Brown, B. B. J. Org. Chem. 1997, 62, 8708.

225. Frank, S. A.; Chen, H.; Kunz, R. K.; Schnaderbeck, M. J.; Roush, W. R. Org. Lett. 2000, 2, 2691. 
226. Willis, M. C.; Claverie, C. K. Tetrahedron Lett. 2001, 42, 5105.

227. Maddaford, S. P.; Keay, B. A. J. Org. Chem. 1994, 59, 6501.

228. Chowdhury, S.; Georghiou, P. E. Tetrahedron Lett. 1999, 40, 7599.

229. Pergament, I.; Srebnik, M. Tetrahedron Lett. 2001, 42, 8059.

230. Pergament, I.; Srebnik, M. Org. Lett. 2001, 3, 217.

231. Nan, Y.; Yang, Z. Tetrahedron Lett. 1999, 40, 3321.

232. (a) Chen, C.; Wilcoxen, K.; Strack, N.; McCarthy, J. R. Tetrahedron Lett. 1999, 40, 827. (b) Eddarir, S.; Abdelhadi, Z.; Rolando, C. Tetrahedron Lett. 2001, 42, 9127.

233. DeBoos, G. A.; Fullbrook, J. J.; Owton, W. M.; Percy, J. M.; Thomas, A. C. Synlett 2000, 963.

234. Hénaff, N.; Whiting, A. J. Chem. Soc., Perkin Trans. 1 2000, 395.

235. Allain, L.; Bégué, J.-P.; Bonnet-Delpon, D.; Bouvet, D. Synthesis 1998, 847.

236. Jiang, B.; Wang, Q.-F.; Yang, C.-G.; Xu, M. Tetrahedron Lett. 2001, 42, 4083.

237. Eastwood, P. R. Tetrahedron Lett. 2000, 41, 3705.

238. Uenishi, J.; Matsui, K. Tetrahedron Lett. 2001, 42, 4353.

239. Kalinin, V. N.; Denisov, F. S.; Bubnov, Y. N. Mendeleev Commun. 1996, 206.

240. Desurmont, G.; Dalton, S.; Giolando, D. M.; Srebnik, M. J. Org. Chem. 1996, 61, 7943.

241. Fürstner, A.; Seidel, G. Synlett 1998, 161.

242. Iglesias, B.; Alvarez, R.; de Lera, A. R. Tetrahedron 2001, 57, 3125.

243. Kamatani, A.; Overman, L. E. J. Org. Chem. 1999, 64, 8743.

244. Kane, J. L.; Shea, Jr. K. M.; Crombie, A. L.; Danheiser, R. L. Org. Lett. 2001, 3, 1081.

245. Lapinsky, D. J.; Bergmeier, S. C. Tetrahedron Lett. 2001, 42, 8583.

246. Charette, A. B.; Giroux, A. J. Org. Chem. 1996, 61, 8718.

247. Hildebrand, J. P.; Marsden, S. P. Synlett 1996, 893.

248. Yao, M.-L.; Deng, M.-Z. Synthesis 2000, 1095.

249. Zhou, S.-M.; Yan, Y.-L.; Deng, M.-Z. Synlett 1998, 198.

250. Yao, M.-L.; Deng, M.-Z. New J. Chem. 2000, 24, 425.

251. Chen, H.; Deng, M.-Z. J. Chem. Soc., Perkin Trans. 12000 , 1609.

252. Zhou, S.-M.; Deng, M.-Z.; Xia, L.-J.; Tang, M.-H. Angew. Chem., Int. Ed. 1998, 37, 2845.

253. Luithle, J. E. A.; Pietruszka, J. J. Org. Chem. 1999, 64, 8287.

254. Soderquist, J. A.; Huertas, R.; Leon-Colon, G. Tetrahedron Lett. 2000, 41, 4251.

255. Molander, G. A.; Ito, T. Org. Lett. 2001, 3, 393.

256. (a) Zou, G.; Falck, J. R. Tetrahedron Lett. 2001, 42, 5817. (b) Zou, G.; Reddy, Y. K.; Falck, J. R. Tetrahedron Lett. 2001, 42, 7213 .

257. Gray, M.; Andrews, I. P.; Hook, D. F.; Kitteringham, J.; Voyle, M. Tetrahedron Lett. 2000, 41, 6237.

258. Niu, C.; Li, J.; Doyle, T. W.; Chen, S.-H. Tetrahedron 1998, 54,6311 .

259. (a) Netherton, M. R.; Dai, C.; Neuschütz, K.; Fu, G. C. J. Am. Chem. Soc. 2001, 123, 10099. (b) Dai, C.; Fu, G. C. J. Am. Chem. Soc. 2001, 123, 2719.

260. Soderquist, J. A.; Matos, K.; Rane, A.; Ramos, J. Tetrahedron Lett. 1995, 36, 2401.

261. Fürstner, A.; Seidel, G. Tetrahedron 1995, 51, 11165.

262. Castanet, A.-S.; Colobert, F.; Schlama, T. Org. Lett. 2000, 2 , 3559.

263. Gonzalez, D.; Martinot, T.; Hudlicky, T. Tetrahedron Lett. 1999, 40, 3077 .
264. Pridgen, L. N.; Huang, G. K. Tetrahedron Lett. 1998, 39, 8421.

265. Ma, D.; Wu, Q. Tetrahedron Lett. 2001, 42, 5279.

266. Sakamuri, S.; George, C.; Flippen-Anderson, J.; Kozikowski, A. P. Tetrahedron Lett. 2000, 41, 2055.

267. Huffman, M. A.; Yasuda, N. Synlett 1999, 471.

268. Raw, S. A.; Taylor, R. J. K. Tetrahedron Lett. 2000, 41, 10357.

269. Organ, M. G.; Kaldor, S. W.; Dixon, C. E.; Parks, D. J.; Singh, U.; Lavorato, D. J.; Isbester, P. K.; Siegel, M. G. Tetrahedron Lett. 2000, 41, 8407.

270. Falck, J. R.; Kumar, P. S.; Reddy, Y. K.; Zou, G.; Capdevila, J. H. Tetrahedron Lett. 2001, 42, 7211.

271. Lisowski, V.; Robba, M.; Rault, S. J. Org. Chem. 2000, 65, 4193.

272. Kamenecka, T. M.; Park, Y.-J.; Lin, L. S.; Lanza, Jr. T.; Hagmann, W. K. Tetrahedron Lett. 2001, 42, 8571.

273. Claus, E.; Kalesse, M. Tetrahedron Lett. 1999, 40, 4157.

274. Hanisch, I.; Brückner, R. Synlett 2000, 374.

275. Heitsch, H.; Wagner, A.; Yadav-Bhatnager, N.; GriffoulMarteau, C. Synthesis 1996, 1325.

276. Lee, J. H.; Park, E. S.; Yoon, C. M. Tetrahedron Lett. 2001, 42, 8311.

277. Geen, G. R.; Mann, I. S.; Mullane, M. V. Tetrahedron 1998, 54, 9875.

278. Chan, F.; Magnus, P.; McIver, E. G. Tetrahedron Lett. 2000 , 41, 835

279. Bagley, M. C.; Moody, C. J.; Pepper, A. G. Tetrahedron Lett. 2000, 41, 6901.

280. Vedejs, E.; Zajac, M. A. Org. Lett. 2001, 3, 2451.

281. Hobbs, P. D.; Upender, V.; Dawson, M. I. Synlett 1997, 965.

282. de Koning, C. B.; Michael, J. P.; van Otterlo, W. A. L. Tetrahedron Lett. 1999, 40, 3037.

283. Yoshida, M.; Mori, K. Eur. J. Org. Chem. 2000, 1313.

284. (a) Faul, M. M.; Ratz, A. M.; Sullivan, K. A.; Trankle, W. G.; Winneroski, L. L. J. Org. Chem. 2001, 66, 5772. (b) Pazos, Y.; Iglesias, B.; de Lera, A. R. J. Org. Chem. 2001, 66, 8483.

285. Nakamura, H.; Aizawa, M.; Takeuchi, D.; Murai, A.; Shimoura, O. Tetrahedron Lett. 2000, 41, 2185.

286. Csányi, D.; Hajós, G.; Riedl, Z.; Timári, G.; Bajor, Z.; Cochard, F.; Sapi, J.; Laronze, J.-Y. Bioorg. Med. Chem. Lett. 2000, 10, 1767.

287. Shin, S. S.; Noh, M.-S.; Byun, Y. J.; Choi, J. K.; Kim, J. Y.; Lim, K. M.; Ha, J.-Y.; Kim, J. K.; Lee, C. H.; Chung, S. Bioorg. Med. Chem. Lett. 2001, 11, 165.

288. Balog, A.; Harris, C.; Savin, K.; Zhang, X.-G.; Chou, T. C.; Danishefsky, S. J. Angew. Chem., Int. Ed. 1998, 37, 2675.

289. Zhu, B.; Panek, J. S. Org. Lett. 2000, 2, 2575.

290. Sasaki, M.; Fuwa, H.; Ishikawa, M.; Tachibana, K. Org. Lett 1999, $1,1075$.

291. Sasaki, M.; Noguchi, K.; Fuwa, H.; Tachibana, K. Tetrahedron Lett. 2000, 41, 1425.

292. Fuwa, H.; Sasaki, M.; Tachibana, K. Tetrahedron 2001, 57, 3019.

293. Kallan, N. C.; Halcomb, R. L. Org. Lett. 2000, 2, 2687.

294. Trauner, D.; Schwarz, J. B.; Danishefsky, S. J. Angew. Chem., Int. Ed. 1999, 38, 3542.

295. Baldwin, J. E.; James, D. A.; Lee, V. Tetrahedron Lett. 2000, $41,733$.

296. Link, J. T.; Sorensen, B. K. Tetrahedron Lett. 2000, 41, 9213.

297. Esteban, G.; López-Sánchez, M. A.; Martínez, M. E.; Plumet, J. Tetrahedron 1998, 54, 197.

298. Johns, B. A.; Johnson, C. R. Tetrahedron Lett. 1998, 39, 749. 
299. Fürstner, A. Synlett 1999, 1523. and references cited therein. 300. Meng, D.; Danishefsky, S. J. Angew. Chem., Int. Ed. 1999, $38,1485$.

301. Gravett, E. C.; Hilton, P. J.; Jones, K.; Romero, F. Tetrahedron Lett. 2001, 42, 9081.

302. Brimble, M. A.; Neville, D.; Duncalf, L. J. Tetrahedron Lett. 1998, 39, 5647.

303. Walsh, T. F.; Toupence, R. B.; Ujjainwalla, F.; Young, J. R.; Goulet, M. T. Tetrahedron 2001, 57, 5233.

304. Witulski, B.; Buschmann, N.; Bergsträßer, U. Tetrahedron 2000, 56, 8473.

305. Baldwin, J. E.; Adlington, R. M.; Roussi, F.; Bulger, P. G.; Marquez, R.; Mayweg, A. V. W. Tetrahedron 2001, 57, 7409.

306. Vyvyan, J. R.; Peterson, E. A.; Stephan, M. L. Tetrahedron Lett. 1999, 40, 4947.

307. Yick, C.-Y.; Wong, H. N. C. Tetrahedron 2001, 57, 6935.

308. Farrall, M. J.; Fréchet, J. M. J. J. Org. Chem. 1976, 41, 3877.

309. Frenette, R.; Friesen, R. W. Tetrahedron Lett. 1994, 35, 9177.

310. Lago, M. A.; Nguyen, T. T.; Bhatnagar, P. Tetrahedron Lett. 1998, 39, 3885.

311. Baxter, E. W.; Rueter, J. K.; Nortey, S. O.; Reitz, A. B. Tetrahedron Lett. 1998, 39, 979.

312. Chamoin, S.; Houldsworth, S.; Kruse, C. G.; Bakker, W. I.; Snieckus, V. Tetrahedron Lett. 1998, 39, 4179.

313. Huwe, C. M.; Künzer, H. Tetrahedron Lett. 1999, 40, 683.

314. Han, Y.; Roy, A.; Giroux, A. Tetrahedron Lett. 2000, 41, 5447.

315. De, D.; Krogstad, D. J. Org. Lett. 2000, 2, 879.

316. Hone, N. D.; Payne, L. J.; Tice, C. M. Tetrahedron Lett. 2001, 42, 1115.

317. Grigg, R.; MacLachlan, W. S.; MacPherson, D. T.; Sridharan, V.; Suganthan, S. Tetrahedron 2001, 57, 10335.

318. Brill, W. K.-D.; Riva-Toniolo, C. Tetraheron Lett. 2001, 42, 6515.

319. Zhang, H.-C.; Ye, H.; White, K. B.; Maryanoff, B. E. Tetrahedron Lett. 2001, 42, 4751.

320. Hall, D. G.; Tailor, J.; Gravel, M. Angew. Chem., Int. Ed. 1999, 38, 3064.

321. Carboni, B.; Pourbaix, C.; Carreaux, F.; Deleuze, H.; Maillard, B. Tetrahedron Lett. 1999, 40, 7979.

322. (a) Arimori, S.; Hartley, J. H.; Bell, M. L.; Oh, C. S.; James, T. D. Tetrahedron Lett. 2000, 41, 10291. (b) Pourbaix, C.; Carreaux, F.; Carboni, B. Org. Lett. 2001, 3, 803. (c) Lobrégat, V.; Alcaraz, G.; Bienaymé, H.; Vaultier, M. Chem. Commun. 2001, 817. (d) Li, W.; Burgess, K. Tetrahedron Lett. 1999, 40, 6527. (e) Pan, Y.; Ruhland, B.; Holmes, C. P. Angew. Chem., Int. Ed. 2001, 40, 4488.

323. (a) Dolle, R. E. J. Comb. Chem. 2001, 3, 1. (b) Kobayashi, S. Curr. Opin. Chem. Biol. 2000, 4, 338. (c) Thompson, L. A. Curr. Opin. Chem. Biol. 2000, 4, 324. (d) Blaser, H.-U.; Indolese, A.; Schnyder, A.; Steiner, H.; Studer, M. J. Mol. Cat. A: Chem. 2001, 173, 3. (e) Solid-Phase Organic Synthesis; Burgess, K., Ed.; John Wiley: New York, 2000.
324. Chan, D. M. T.; Monaco, K. L.; Wang, R.-P.; Winters, M. P. Tetrahedron Lett. 1998, 39, 2933.

325. Lam, P. Y. S.; Clark, C. G.; Saubern, S.; Adams, J.; Winters, M. P.; Chan, D. M. T.; Combs, A. Tetrahedron Lett. 1998, 39, 2941.

326. Evans, D. A.; Katz, J. L.; West, T. R. Tetrahedron Lett. 1998, 39, 2937.

327. Collman, J. P.; Zhong, M. Org. Lett. 2000, 2, 1233.

328. Lam, P. Y. S.; Vincent, G.; Clark, C. G.; Deudon, S.; Jadhav, P. K. Tetrahedron Lett. 2001, 42, 3415.

329. Antilla, J. C.; Buchwald, S. L. Org. Lett. 2001, 3, 2077.

330. Petrassi, H. M.; Sharpless, K. B.; Kelly, J. W. Org. Lett. 2001, 3, 139.

331. Decicco, C. P.; Song, Y.; Evans, D. A. Org. Lett. 2001, 3, 1029.

332. Herradura, P. S.; Pendola, K. A.; Guy, R. K. Org. Lett. 2000, 2, 2019

333. (a) Ishiyama, T.; Kizaki, H.; Hayashi, T.; Suzuki, A.; Miyaura, N. J. Org. Chem. 1998, 63, 4726. (b) Ishiyama, T.; Kizaki, H.; Suzuki, A.; Miyaura, N. Tetrahedron Lett. 1993, 34, 7595 .

334. Cho, C. S.; Itotani, K.; Uemura, S. J. Organomet. Chem. 1993, 443, 253

335. Bumagin, N. A.; Korolev, D. N. Tetrahedron Lett. 1999, 40, 3057.

336. Haddach, M.; McCarthy, J. R. Tetrahedron Lett. 1999, 40, 3109.

337. Couve-Bonnaire, S.; Carpentier, J.-F.; Mortreux, A.; Castanet, Y. Tetrahedron Lett. 2001, 42, 3689.

338. Chen, H.; Deng, M.-Z. Org. Lett. 2000, 2, 1649.

339. Gooßen, L. J. Chem. Commun. 2001, 669.

340. Gooßen, L. J.; Ghosh, K. Angew. Chem., Int. Ed. 2001, 40, 3458.

341. Hayashi, T. Synlett 2001, 879.

342. Senda, T.; Ogasawara, M.; Hayashi, T. J. Org. Chem. 2001, 66, 6852.

343. Ramnauth, J.; Poulin, O.; Rakhit, S.; Maddaford, S. P. Org. Lett. 2001, 3, 2013.

344. Ramnauth, J.; Poulin, O.; Bratovanov, S. S.; Rakhit, S.; Maddaford, S. P. Org. Lett. 2001, 3, 2571.

345. Fürstner, A.; Krause, H. Adv. Synth. Catal. 2001, 343, 343.

346. Moreau, C.; Hague, C.; Weller, A. S.; Frost, C. G. Tetrahedron Lett. 2001, 42, 6957.

347. (a) Sakai, M.; Ueda, M.; Miyaura, N. Angew. Chem., Int. Ed. 1998, 37, 3279. (b) Ueda, M.; Miyaura, N. J. Org. Chem. 2000, 65,4450 .

348. Batey, R. A.; Thadani, A. N.; Smil, D. V. Org. Lett. 1999, 1, 1683.

349. Lautens, M.; Yoshida, M. Org. Lett. 2002, 4, 123.

350. Chung, K.-G.; Miyake, Y.; Uemura, S. J. Chem. Soc., Perkin Trans. 1 2001, 15.

351. Cho, J.-Y.; Tse, M. K.; Holmes, D.; Maleczka, Jr. R. E.; Smith, III., M. R. Science 2002, 295, 305.

352. Fürstner, A.; Seidel, G. Org. Lett. 2002, 4, 541. 


\section{Biographical sketch}

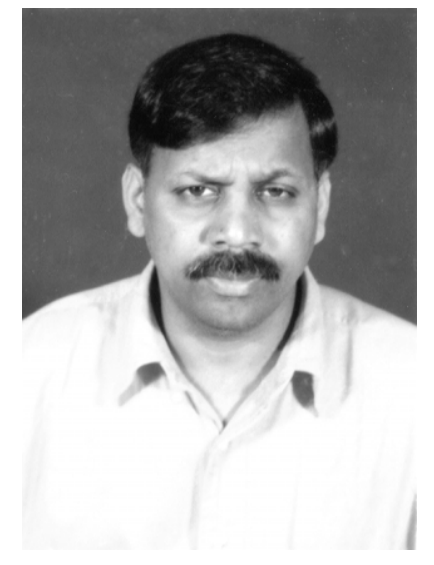

Sambasivarao Kotha was born in Amarthalur, Guntur District, AP, India. He received his B.Sc. degree from Nagarjuna University in 1977 and his M.Sc. degree from the University of Hyderabad in 1979. In 1985, he obtained his Ph.D. degree under the supervision of Professor G. Mehta at the University of Hyderabad. Subsequently, he worked with Professor R. J. Stoodley (1986-87) at UMIST, Manchester, UK and Professor J. M. Cook (1987-89) at the University of Wisconsin, Milwaukee as a research associate. Later, he joined Cornell University as a visiting scientist and worked in Professor A. Kuki's group on AIB peptide synthesis. During 1992-93, he worked in Hoechst Celanese, Corpus Christi, Texas as a Research Chemist-II. In 1994, he joined IIT-Bombay as an Assistant Professor and was promoted to a Professor in 2001. He was a recipient of the B.M. Birla prize in Chemical Sciences (1996) and the Professor N. S. Narasimhan Endowment Award (2000). His current research interests include methods in organic synthesis, unusual amino acids, peptide modifications, Suzuki coupling, metathesis and theoretically interesting molecules.

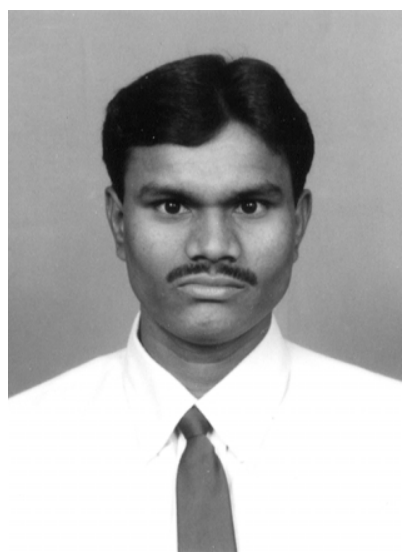

Dhurke Kashinath was born in Lonavelly, Adilabad District, AP, India. He received his B.Sc. degree from Kakatiya University, Warangal in 1996 and his M.Sc. degree from Osmania University, Hyderabad in 1998. He joined the Ph.D. programme under the guidance of Professor S. Kotha in the Department of Chemistry, Indian Institute of Technology-Bombay in January 2000. Presently, he is continuing as a Senior Research Fellow in this department. His research interests are the development of new synthetic methods and transition metal-catalysed organic functional group transformations.

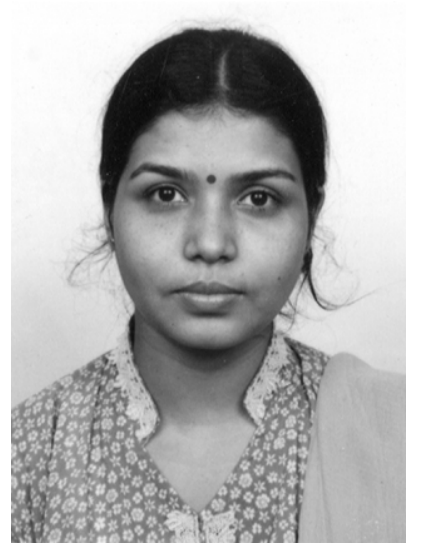

Kakali Lahiri (née Chakraborty) was born in Hooghly, West Bengal. She obtained her B.Sc. degree in chemistry from Burdwan University, West Bengal in 1993 and her M.Sc. degree in organic chemistry from Burdwan University in December 1995. In 2002, she obtained her Ph.D. degree under the guidance of Professor S. Kotha from the Department of Chemistry, Indian Institute of Technology-Bombay. Presently, she is working as a Research Associate in the Department of Chemistry, Indian Institute of Technology-Bombay. Her research interests are the development of new methodologies for the synthesis of interesting molecular frames and the modification of peptides. 